


\section{National Interest Organizations in the EU Multilevel System}

Political scientists have always accorded interest organizations a prominent place in European Union (EU) policy-making because they connect the EU institutions to citizens, provide important information to EU policy-makers, and control resources that impact on the problem-solving capacity of EU policies. In other words, they are vital to both the input legitimacy and the output legitimacy of the EU. So far, research on interest organizations in EU policy-making has concentrated on EU-level interest organizations and EU-level politics. This edited book draws attention to the role national interest organizations play in the EU multilevel system. All contributions present state-of-the-art research on that subject in the form of theory-driven empirical analyses. The ten chapters indicate that national interest organizations have adapted to the EU's multilevel polity in terms of their strategies; their relations with parliaments, governments, and the EU institutions; as well as their collaboration with EU umbrella organizations. Especially, they offer new insights into the alignments among national interest organizations and decision-makers, the Europeanisation of these organizations in established EU member states and candidate countries, and the existence of bias in national and EU interest group populations.

The chapters in this book were originally published in a special issue of West European Politics.

Rainer Eising is Professor of Comparative Politics at the Ruhr University Bochum, Germany. He has published widely on interest groups, multilevel governance, and policy-making in the EU. He was principal investigator in the INTEREURO project and has recently directed a MERCUR project on interest groups in German political arenas.

Daniel Rasch is Postdoctoral Researcher at the German University of Administrative Sciences Speyer. His research focuses on international as well as national interest mediation, governance, and research methods.

Patrycja Rozbicka is Lecturer in Politics and International Relations at the Aston Centre for Europe, Aston University, Birmingham, UK. Her research focuses on the comparative analysis of interest groups' activity in national and European policy-making and politics of the live music industry in the UK and Europe. 


\section{West European Politics}

Edited by Klaus H. Goetz, University of Munich, Germany

Anand Menon, King's College London, UK

Wolfgang C. Müller, University of Vienna, Austria

West European Politics has established itself as the foremost journal for the comparative analysis of European political institutions, politics, and public policy. Its comprehensive scope, which includes the EU, makes it essential reading for both academics and political practitioners. The books in this series have originated from special issues published by West European Politics.

Recent titles in this series include:

Decision Making in the EU Before and After the Lisbon Treaty

Edited by Madeleine Hosli, Amie Kreppel, Běla Plechanovová and Amy Verdun

\section{Party Politics and Democracy in Europe}

Essays in Honour of Peter Mair

Edited by Ferdinand Müller-Rommel and Fernando Casal Bértoa

\section{Europe's Union in Crisis}

Tested and Contested

Edited by Brigid Laffan

\section{Challenging Executive Dominance}

Legislatures and Foreign Affairs

Edited by Tapio Raunio and Wolfgang Wagner

\section{Electoral Rules and Electoral Behaviour}

The Scope of Effects

Edited by Ruth Dassonneville, Marc Hooghe and Michael S. Lewis-Beck

\section{The Politics of Supranational Banking Supervision in Europe}

Edited by David Howarth and Huw Macartney

\section{National Interest Organizations in the EU Multilevel System}

Edited by Rainer Eising, Daniel Rasch and Patrycja Rozbicka

For a complete list of titles in this series, please visit https://www.routledge.com/ West-European-Politics/book-series/WEP 


\title{
National Interest Organizations in the EU Multilevel System
}

\author{
Edited by \\ Rainer Eising, Daniel Rasch \\ and Patrycja Rozbicka
}


First published 2019

by Routledge

2 Park Square, Milton Park, Abingdon, Oxon, OX14 4RN, UK

and by Routledge

52 Vanderbilt Avenue, New York, NY 10017, USA

Routledge is an imprint of the Taylor \& Francis Group, an informa business

Introduction, Chapters 1-7 (c) 2019 Taylor \& Francis

Chapter 8 (c) 2017 Joost Berkhout, Marcel Hanegraaff and Caelesta Braun.

Originally published as Open Access.

Chapter 9 (C) 2017 Brendan J. Carroll and Anne Rasmussen. Originally published as Open Access.

With the exception of Chapters 8 and 9, no part of this book may be reprinted or reproduced or utilised in any form or by any electronic, mechanical, or other means, now known or hereafter invented, including photocopying and recording, or in any information storage or retrieval system, without permission in writing from the publishers. For details on the rights for Chapters 8 and 9, please see the chapters' Open Access footnotes.

Chapter 8 of this book is available for free in PDF format as Open Access from the individual product page at www.routledge.com. It has been made available under a Creative Commons Attribution-Non Commercial-No Derivatives 4.0 license.

Trademark notice: Product or corporate names may be trademarks or registered trademarks, and are used only for identification and explanation without intent to infringe.

British Library Cataloguing-in-Publication Data

A catalogue record for this book is available from the British Library

ISBN13: 978-1-138-61474-1

Typeset in Minion Pro

by codeMantra

\section{Publisher's Note}

The publisher accepts responsibility for any inconsistencies that may have arisen during the conversion of this book from journal articles to book chapters, namely the possible inclusion of journal terminology.

\section{Disclaimer}

Every effort has been made to contact copyright holders for their permission to reprint material in this book. The publishers would be grateful to hear from any copyright holder who is not here acknowledged and will undertake to rectify any errors or omissions in future editions of this book. 


\section{Contents}

Citation Information vii

Notes on Contributors ix

Introduction: National interest organisations in EU policy-making $\quad 1$

Rainer Eising, Daniel Rasch and Patrycja Rozbicka

\section{PART I}

\section{Studying the alignments of national interest} organisations

1 Who says what to whom? Alignments and arguments in EU policy-making

Rainer Eising, Daniel Rasch, Patrycja Rozbicka,

Danica Fink-Hafner, Mitja Hafner-Fink and Meta Novak

2 Government-business relations in multilevel systems: the effect of conflict perception on venue choice

David Marshall and Patrick Bernhagen

3 German MPs and interest groups in EU multilevel policy-making: the politics of information exchange

Arndt Wonka

4 Imperfect public goods and the logic of selective exit in EU interest organisations

Rainer Eising 


\section{PART II}

\section{Europeanisation and access of national} interest organisations

5 The multilevel interest representation of national business associations

Beate Kohler-Koch, Peter Kotzian and Christine Quittkat

6 Adapting to Europe? Business interests and civil society groups in accession countries

Aneta Cekik

7 Networkers, fund hunters, intermediaries, or policy players? The activities of regions in Brussels Michaël Tatham

\section{PART III}

\section{Population ecology of interest organisations} in the EU: a biased system?

8 Is the EU different? Comparing the diversity of national and EU-level systems of interest organisations Joost Berkhout, Marcel Hanegraaff and Caelesta Braun

9 Cultural capital and the density of organised interests lobbying the European Parliament

Brendan J. Carroll and Anne Rasmussen 


\section{Citation Information}

The chapters in this book were originally published in the journal West European Politics, volume 40, issue 5 (September 2017). When citing this material, please use the original page numbering for each article, as follows:

\section{Introduction}

National interest organisations in EU policy-making

Rainer Eising, Daniel Rasch and Patrycja Rozbicka

West European Politics, volume 40, issue 5 (September 2017) pp. 939-956

\section{Chapter 1}

Who says what to whom? Alignments and arguments in EU policy-making Rainer Eising, Daniel Rasch, Patrycja Rozbicka, Danica Fink-Hafner, Mitja Hafner-Fink and Meta Novak

West European Politics, volume 40, issue 5 (September 2017) pp. 957-980

\section{Chapter 2}

Government-business relations in multilevel systems: the effect of conflict perception on venue choice

David Marshall and Patrick Bernhagen

West European Politics, volume 40, issue 5 (September 2017) pp. 981-1003

\section{Chapter 3}

German MPs and interest groups in EU multilevel policy-making: the politics of information exchange

Arndt Wonka

West European Politics, volume 40, issue 5 (September 2017) pp. 1004-1024

\section{Chapter 4}

Imperfect public goods and the logic of selective exit in EU interest organisations Rainer Eising

West European Politics, volume 40, issue 5 (September 2017) pp. 1025-1045 


\section{Chapter 5}

The multilevel interest representation of national business associations

Beate Kohler-Koch, Peter Kotzian and Christine Quittkat

West European Politics, volume 40, issue 5 (September 2017) pp. 1046-1065

\section{Chapter 6}

Adapting to Europe? Business interests and civil society groups in accession countries

Aneta Cekik

West European Politics, volume 40, issue 5 (September 2017) pp. 1066-1087

\section{Chapter 7}

Networkers, fund hunters, intermediaries, or policy players? The activities of regions in Brussels

Michaël Tatham

West European Politics, volume 40, issue 5 (September 2017) pp. 1088-1108

\section{Chapter 8}

Is the EU different? Comparing the diversity of national and EU-level systems of interest organisations

Joost Berkhout, Marcel Hanegraaff and Caelesta Braun

West European Politics, volume 40, issue 5 (September 2017) pp. 1109-1131

\section{Chapter 9}

Cultural capital and the density of organised interests lobbying the European Parliament

Brendan J. Carroll and Anne Rasmussen

West European Politics, volume 40, issue 5 (September 2017) pp. 1132-1152

For any permission-related enquiries please visit:

http://www.tandfonline.com/page/help/permissions 


\section{Notes on Contributors}

Joost Berkhout is Assistant Professor of Political Science at the University of Amsterdam, the Netherlands. His main research focus is in the field of interest group politics. He currently conducts research on the differences between the numbers and types of interest groups per sector and per country.

Patrick Bernhagen is Professor of Comparative Political Science at the University of Stuttgart, Germany. His main research interest is the political participation of citizens and firms. He is the author of The Political Power of Business: Structure and Information in Public Policymaking (Routledge, 2007).

Caelesta Braun is Associate Professor in Public Administration at Leiden University, the Netherlands. Her main fields of research include interest representation and regulatory governance, with a focus on political behaviour of organized interests, stakeholder management of regulatory authorities, and decision-making.

Brendan J. Carroll is Assistant Professor at the Institute of Public Administration at Leiden University, the Netherlands. He teaches and publishes on research design and methods, comparative public policy, regulatory implementation, EU governance, and interest group advocacy/lobbying.

Aneta Cekik is Associate Professor of Political Science at the Institute for Sociological, Political and Juridical Research at Ss. Cyril and Methodius University in Skopje, Republic of Macedonia. Her research interests include interest group politics, EU politics, EU lobbying, and ethnic politics.

Rainer Eising is Professor of Comparative Politics at the Ruhr University Bochum, Germany. He has published widely on interest groups, multilevel governance, and policy-making in the EU. He was principal investigator in the INTEREURO project and has recently directed a MERCUR project on interest groups in German political arenas.

Danica Fink-Hafner is Professor in the Faculty of Social Sciences at the University of Ljubljana, Slovenia, and Head of the Political Science Research Programme (P5-0136). She has published articles in international journals such as the Journal of European Public Policy, Europe-Asia Studies, and the Journal of Southern Europe and the Balkans. 
Mitja Hafner-Fink is Associate Professor of Social Science Methodology and Comparative Social Research in the Faculty of Social Sciences at the University of Ljubljana, Slovenia, and is Head of the Slovenian Public Opinion Research Programme. He has published articles in international journals such as Culture and Europe-Asia Studies.

Marcel Hanegraaff is Assistant Professor in Political Science at the University of Amsterdam, the Netherlands. His research is on the politics of interest representation in a transnational and EU context, as well as on the functioning of international organizations in the fields of climate change and global trade.

Beate Kohler-Koch is former Professor at the University of Mannheim, Germany, and is a Project Director at the Mannheim Centre for European Social Research (MZES) at the University of Mannheim, Germany. Her research interests concern efficient and democratic governance beyond the nation state and interest intermediation in multilevel systems.

Peter Kotzian is Postdoctoral Research Assistant at the University of Düsseldorf, Germany. His research interests cover comparative politics and the involvement of civil society organizations in policy-making at the European and international level.

David Marshall is Lecturer in Comparative Politics at the University of Reading, UK. His principal research interest is the political engagement of citizen and business interests with the policy-making process. He has published widely on this topic.

Meta Novak is Assistant Professor, and a Researcher at the Centre for Political Science Research, in the Faculty of Social Sciences at the University of Ljubljana, Slovenia. She is the author and co-author of several monographs and part monographs.

Christine Quittkat is Research Project Manager at the German Association of Occupational Medicine. Her research interests are in the areas of European governance and comparative politics. She has done research on questions of legitimacy, democracy, and the EU; focusing especially on organised civil society and lobbying.

Daniel Rasch is Postdoctoral Researcher at the German University of Administrative Sciences Speyer. His research focuses on international as well as national interest mediation, governance, and research methods.

Anne Rasmussen is Professor in Political Science at the University of Copenhagen, Denmark, is affiliated to the Institute of Public Administration at Leiden University, the Netherlands, and is a Fellow at the Montesquieu Institute at Maastricht University, the Netherlands. Her current research analyses decision-making, political parties, interest representation, and political responsiveness. 
Patrycja Rozbicka is Lecturer in Politics and International Relations at the Aston Centre for Europe, Aston University, Birmingham, UK. Her research focuses on the comparative analysis of interest groups' activity in national and European policy-making and politics of the live music industry in the UK and Europe.

Michaël Tatham is Professor of Comparative Politics at the University of Bergen, Norway. He is co-chairman of the CES research network on Territorial Politics and Federalism, co-editor of the journal Regional \& Federal Studies, and coeditor of the Palgrave Macmillan Comparative Territorial Politics book series.

Arndt Wonka is Senior Researcher at the Bremen International Graduate School of Social Sciences (BIGSSS), Germany, and Affiliated Researcher at the SOCIUM Research Centre on Inequality and Social Policy at the University of Bremen, Germany. His research interests include EU studies and political mobilisation and political contestation of interest groups and political parties. 
$\Longrightarrow$ Taylor \& Francis

Taylor \& Francis Group

http://taylorandfrancis.com 


\title{
National interest organisations in EU policy-making
}

\author{
Rainer Eising, Daniel Rasch and Patrycja Rozbicka
}

\begin{abstract}
Comparative and EU interest group studies are marked by a progression towards theory-driven, large- $N$ empirical studies in the past 20 years. With the study of national interest organisations in EU policy-making, this special issue puts centre stage a theoretically and empirically neglected topic in this research field. The individual contributions include interest group characteristics, institutional contexts as well as issue contexts as explanatory factors in their empirical analyses of multilevel interest representation. They present novel developments in the study of political alignments among interest groups and political institutions, the Europeanisation of domestic interest organisations, and the question of bias in interest group populations. Thereby, they not only contribute to the comparative study of interest groups, but also to the analysis of policy-making, multilevel governance, and political representation in the EU.
\end{abstract}

Almost 20 years ago, Baumgartner and Leech (1998) suggested in their review of American interest group studies that these were highly fragmented, filled only a research niche, and needed to be empirically broadened and connected with other areas in political science. Ten years later, Beyers et al. (2008) initiated a West European Politics special issue on the study of interest groups in Comparative Politics and European Union studies based on the understanding that the study of interest group systems is crucial to the understanding of the functioning of advanced democracies and multilevel governance in Europe. While confirming that interest group research formed a niche area within political science in which a variety of different research subjects co-exist, they also pointed to the growth of academic interest in group politics. Taking stock almost 10 years on, we can observe a remarkable transformation in the study of the interest representation in both Europe and the United States. 
While still forming a distinct research area with specific research concepts and mid-range theories, the field broadened to build stronger links with scholarship on public opinion (e.g. Rasmussen et al. 2014) and political parties (e.g. Allern and Bale 2012) as well as legislative politics (e.g. Dür et al. 2015) and policy studies (e.g. Baumgartner et al. 2009). At the same time, the empirical scope of interest group studies widened from a focus on small- $N$ studies to large- $N$ research to develop broader empirical and more reliable theoretical generalisations (e.g. Bunea and Baumgartner 2014; Eising 2016). Moreover, modular research projects were designed to integrate insights on major facets of interest group politics: mobilisation, organisation, strategies, influence, population, and bias (e.g. Beyers et al. 2014; Binderkrantz et al. 2015). Lowery et al. (2015: 1228) suggest that 'the transatlantic community of scholars now broadly shares a common methodological approach to a core set of mid-range theories on interest representation. The work of these scholars reaffirmed the importance of studying interest groups in the European Union and in liberal democracies. Most studies now integrate into their research designs as explanatory factors the properties of groups and their members, institutional contexts, and issue characteristics. Before outlining the contribution of this special issue to interest group studies and giving an overview of the individual articles, we will examine these developments.

The recent literature scrutinised both established concepts and theories and ventured into new areas, each on the basis of large sets of observations. Following Olson's (1965) logic of collective action, some studies looked into the mobilisation of different types of interests and their effects on lobbying behaviour and success (e.g. Beyers and Kerremans 2007; Binderkrantz et al. 2015). While Olson (1965: 49-50) distinguished among intermediate and privileged groups on the one hand, and large, latent groups on the other, today's studies tend to separate groups into those for specific interests and those for diffuse interests. Usually, they relate business interests to specific interests which are said to be easier to mobilise, and citizen interests to diffuse interests that are more difficult to mobilise. Recent studies confirm that such group types are major determinants of interest group strategy (Beyers and Kerremans 2007; Dür and Mateo 2016). Their findings often connect the interests of a group (specific versus diffuse) with its strategic choices, with business representatives as exemplary users of inside tactics (aimed at contacting decision-makers) and citizen groups as typical users of outside tactics (aimed at mobilising the public). Further studies (e.g. Dür and De Bièvre 2007) suggest an advantage of specific interests in the generation of resources. They show that specific interests tend to be richer in resources than diffuse interests, because their membership consists of comparatively well-endowed firms. Companies as members tend to spend more money on the representation of interests than individual citizens as members of non-governmental organisations (NGOs). Rasmussen (2015) also points to group unity as a precondition for an interest group's lobbying success. 
All studies explicitly define and measure core concepts in interest group studies such as mobilisation, access, and success. While the evidence on the relation between group type and organisational resources, on the one hand, and access, on the other hand, is quite consistent across different studies, there is less consensus on how finances and group type are related to the success (or preference attainment) of interest organisations and their influence on policy outcomes. Most studies provide evidence that a greater resource endowment of an organisation furthers its access to decision-makers (Dür and Mateo 2016; Eising 2007; Klüver 2011; but see Beyers and Kerremans 2007). The common wisdom is that specific interests tend also to win over diffuse interests in public policy-making (see Lowery et al. 2015). That this is not always true and hinges upon several conditions has not only been shown in Vogel's $(1989,1995)$ analyses of business' fluctuating fortunes and the California and Delaware effects in environmental and consumer protection regulation. Recent studies also confirm that specific interests do not always win in EU legislative politics and that many policy outcomes are closer to the preferences of citizen groups than to those of business interest associations (Dür et al. 2015). Studies taking into account the resource endowment of interest organisation indicate, with respect to the US context, that more resources are not significantly associated with greater success or with more influence (Baumgartner et al. 2009).

Both studies highlight that interest groups' success depends heavily on the responsiveness of policy-makers to their demands. A comparison of their findings points to the intervening role of institutional contexts. While Dür et al.'s (2015) study allows for the interpretation that the structural power of business is frequently insufficient to keep market and social regulation off the EU's policy-making agenda, Baumgartner et al. (2009) argue that the policy status quo in the United States reflects the institutionalisation of bias and is therefore difficult to change. Moreover, as proposal initiation is 'relatively easy', legislators put forward many bills but only 'few bills actually become law' in US federal legislation (Mahoney 2008: 66-7). Accordingly, when the European Commission initiates legislation, policy change is more likely to come about than in the case of federal bills in the US. This has important consequences for interest group mobilisation. In the EU, interest groups are more likely to mobilise in order to defend the policy status quo or to propose alternatives to the policy proposal than in the US (Eising et al. 2017), where interest groups in favour of the status quo are more inclined to do nothing about new policy proposals (Baumgartner et al. 2009).

Several studies refer explicitly to factors located in national and EU-level institutional contexts (e.g. Eising 2007; Klüver et al. 2015). Studies incorporating national institutions distinguish commonly between the classic categories of pluralism and corporatism (e.g. Schneider et al. 2007) or measure as a variety thereof the degree of political-economic integration (Siaroff 1999). Findings show that interest organisations have lobbying styles conforming to the interest 
mediation system they come from, but that they also adapt to the institutional setting they are active in (e.g. Binderkrantz 2003). Other national contexts refer to socio-economic characteristics, the duration of EU membership, ideological orientations of the governing parties, varieties of capitalism in terms of coordinated and liberal market economies (Hall and Soskice 2001) or welfare states in the form of liberal, conservative or social-democratic welfare regimes (EspingAndersen 1990). Although findings differ in some ways, one aspect has been shown by several scholars: lobbying strategies of interest groups vary based on their domestic experiences and institutional settings. The contributions in this special issue corroborate the continuing relevance of domestic contexts for the behaviour of domestic interest groups in EU policy-making.

Regarding the EU institutional context, several studies indicated that the demand for information (Bouwen 2002) and the supply of information (Chalmers 2013) vary across EU decision-making institutions like the European Commission, the European Parliament and the EU Council. Some studies also point to differences within these institutions such as among the Directorates General (DG) of the European Commission because of their varying competencies and regulatory approaches in different policy domains (e.g. Eising and Kohler-Koch 1994). A core expectation in that regard is that different policy fields attract varying levels of interest group attention (Coen and Katsaitis 2013; see also Berkhout et al. 2017). In addition, several authors studied the consultation practices of the European institutions with regard to the presence and activity of interest groups (e.g. Gornitzka and Sverdrup 2008; Klüver 2011), finding that the impact of interest groups varies along the extent of EU competencies in different policy areas. Several authors refer to this as the degree of regulatory exposure'. In particular, Bernhagen and Mitchell (2009) provided evidence that firms acting in industries highly affected by EU regulation are more likely to lobby both directly and collectively at the European level.

With respect to issue characteristics, we find the following: taking Lowi's (1972) classical differentiation between distributive and regulatory issues, researchers expect business interests to gain more from lobbying when distributive issues are discussed since there might be less opposition on them than on regulatory issues (Dür and Mateo 2016). Other differentiations include complex issues versus simple ones, or conflictual and salient issues (Mahoney 2008: 40-41). Issues that are salient to the public attract more stakeholders and increase the possibility of building large lobbying coalitions. Klüver (2011) finds that salience does not have a constant effect on lobbying success but that the more interest groups act on one 'policy side' (Baumgartner et al. 2009) of a salient issue, the more successful they are (see also Kreutler 2014: 175). On highly conflictual issues, interest groups have directly contradictory positions such that striking a compromise and reaching a common position between them seems to be impossible (Mahoney 2008: 74). Mahoney (2008: 40) adds that the scope of issues also matters: niche and sector-related issues allow individual 
interest groups greater leverage than issues with a larger scope. Her findings correspond with Culpepper's notion of 'quiet politics': the narrower an issue is and the less the public cares about it, the more managerial organisations will be able 'to exercise disproportionate influence over the rules governing that issue' (Culpepper 2011: 177). Rasmussen (2015) yields a similar finding with respect to the involvement of business groups in EP committee amendments on incoming EU legislation.

Despite the dynamic development of interest group studies, there are a number of controversial, unresolved, and unaddressed issues that remain. Many studies concentrate on EU-level interest representation and EU-level organisations. It is less common to study the role of domestic groups in EU politics. This is surprising because these do not just present their positions on EU policies routinely to national governments. A large number of them have joined EU-level groups and are also well represented in the governance structures of these organisations. And even though the EU institutions' consultation bodies are still biased towards EU-level groups (Rasmussen and Gross 2015), many national interest organisations participate in the Commission's online consultations and present their interests directly to the European Commission and the European Parliament. Previous research suggests that the EU institutions depend especially on national interest groups to learn about the member states' 'domestic encompassing interest[s]' (Bouwen 2002). Empirical studies covering national interest groups as actors in EU politics confirm that differences in national and $\mathrm{EU}$ contexts, organisational features, and issue characteristics matter to the representation of interests in the EU's multilevel system (Knodt et al. 2011; Bunea and Baumgartner 2014; Klüver et al. 2015), thus the lack of more nuanced studies is surprising especially with regard to venue shopping and its determinants. The study of alignments, i.e. the analysis of the positional and ideological proximity between decision-makers and interest groups is missing, except for analyses looking at the European Parliament (Beyers et al. 2015; Rasmussen 2015) or the US context (e.g. Hojnacki and Kimball 1998). The national perspective on this topic in the EU multilevel system is yet unexplored. Finally, the participation of Southern and Eastern European interest groups in EU policy-making has received fairly little attention (see Cekik 2017).

\section{The contribution of this special issue}

The contributions to this special issue (see also Table 1) move the research on national interest organisations in the EU forward by addressing some of these gaps and controversies. The articles show that the challenge of multilevel interest representation affects the national interest organisations' strategies, organisational structures, relations with national parliaments, governments, and media, their collaboration with EU umbrella organisations and EU institutions, and in the end their possibilities to influence policy-making. They draw 


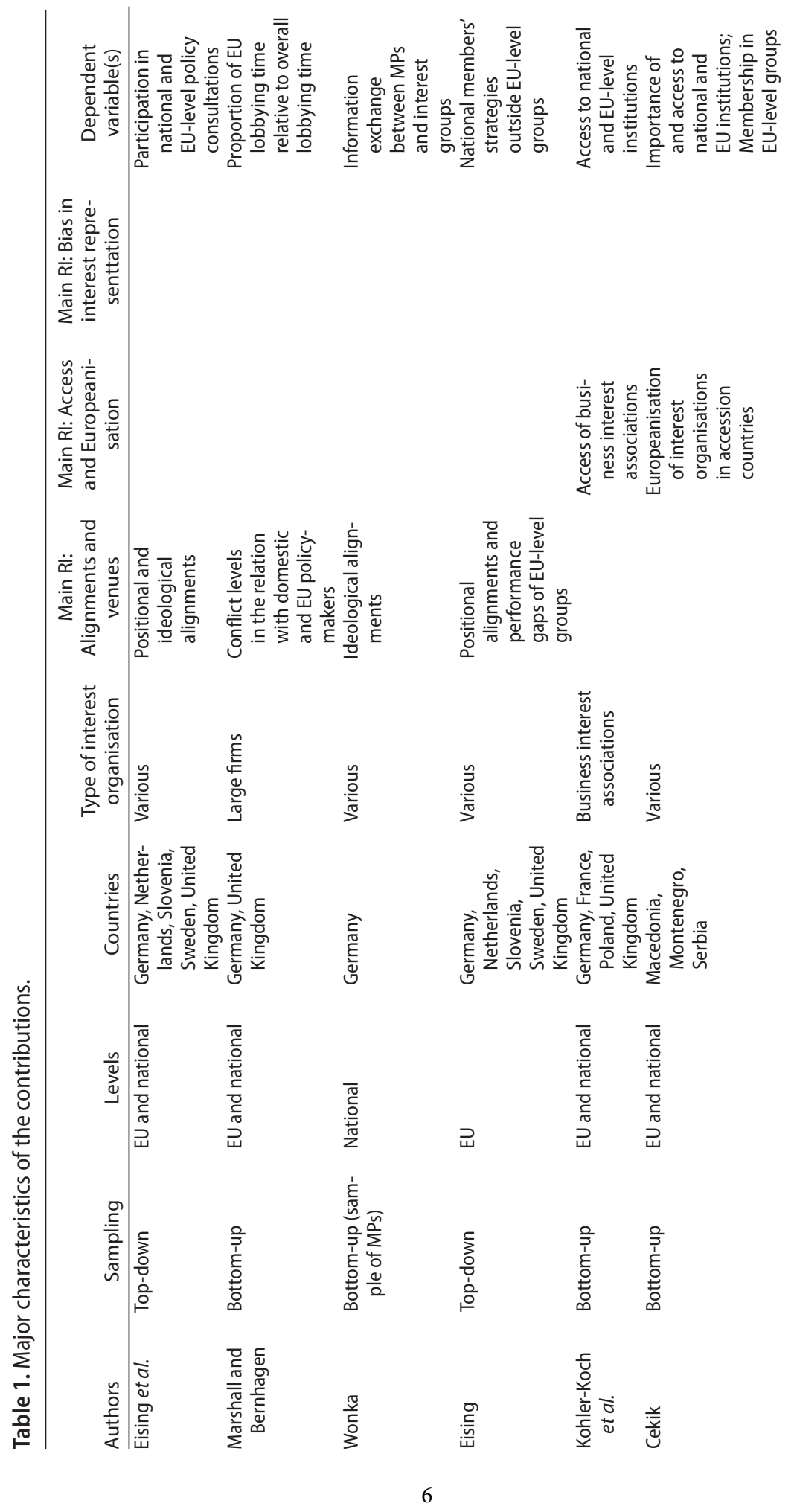





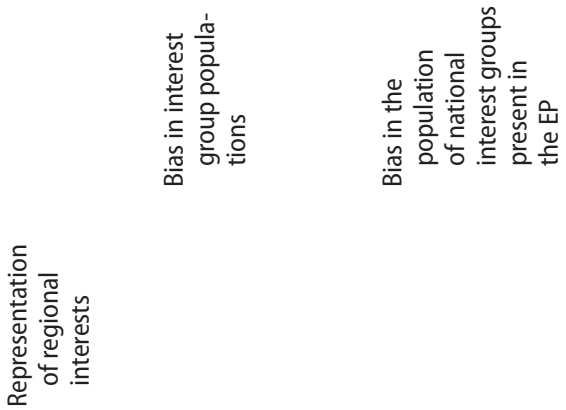

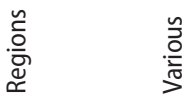

$\frac{n}{\frac{0}{0}}$

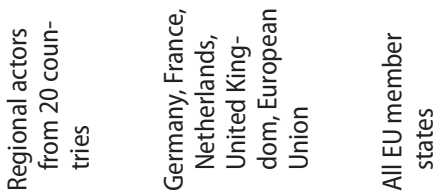

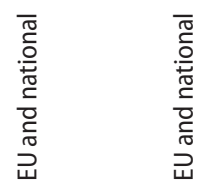

구

$\sum_{0}$
$\frac{0}{1}$
을



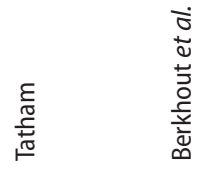

\begin{tabular}{l}
\multirow{2}{3}{} \\
0 \\
0 \\
0 \\
0
\end{tabular}

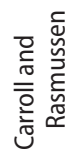


a comprehensive picture of multilevel governance and the policy process in the EU. Addressing Lowery et al.'s (2015: 1128) concern that 'we do very little actual comparison' in interest group studies, most articles (e.g. Berkhout et al. 2017; Carroll and Rasmussen 2017; Cekik 2017; Eising et al. 2017; Kohler-Koch et al. 2017; Marshall and Bernhagen 2017; Tatham 2017) broaden the predominant research design of studies on EU interest representation by connecting multilevel analyses with the comparative study of member state contexts. The contributions vary in their coverage of EU-level and national-level institutions, respectively.

As the EU policy process attracts the attention of a great number and variety of actors (see Beyers et al. 2008), the articles cover not only organised interest groups in a narrow sense (i.e. organised associations) but include also firms, institutions, regions, research institutes, or think tanks. They balance the study of organisations from all EU member states with in-depth analyses of organisations rooted in selected EU member states. A few contributions focus on particular categories of actors: business associations (Kohler-Koch et al. 2017); large firms (Marshall and Bernhagen 2017); and regions (Tatham 2017), while most analyse different types of organisations participating in EU policy-making or present in national and EU populations of interest groups (Berkhout et al. 2017; Carroll and Rasmussen, 2017). All authors conceptualise national contexts and analyse their effects on interest representation. They assess the importance of potentially important factors such as the level of economic prosperity, the duration of EU membership, the mode of national interest mediation, the associability of domestic civil society, the difference between EU member states and candidate countries, party ideologies. Several look also into how issue contexts impact on the lobbying activities of domestic interest organisations (e.g. Cekik 2017; Eising et al. 2017; Wonka 2017), studying the Europeanisation of policies, the type of policy, distinguishing among new and recast proposals (which explicitly aim at amending and replacing existing legislative acts in the EU) as well as among substantial policy areas such as banking and environmental policy.

The contributions yield a number of new insights. In particular, they shed new light on three major research topics: (1) the alignments between interest groups and policy-makers, (2) the Europeanisation and access of interest groups in new EU member states and candidate countries, and (3) the existence of bias in interest group populations.

(1) Several contributions (see below) focus on the alignments between interest groups and political institutions. In this emergent research area, they present different ways of conceptualising and measuring such alignments. Connecting with the literature on political parties, they emphasise the importance of ideological alignments with national members of parliament (Wonka 2017) and national governments 
(Eising et al. 2017) to account for the venues of domestic groups. The importance of such alignments shows in the earlier finding that a close ideological fit with EP committee members made it easier for business representatives to put their stamp on the committees regulating industrial affairs and for environmental groups to do so on the environment, public affairs, and health committees (Rasmussen 2015). Beyond ideological alignments, the contributions showcase the relevance of positional alignments and of domestic and EU-level conflicts for the venue-seeking activities of large firms (Marshall and Bernhagen 2017) and interest organisations in the EU multilevel system (Eising et al. 2017). They also underline the relevance of positional alignments among EU-level interest groups and their national members for the latter's strategic choices outside the EU-level groups, i.e. their use of 'selective exit' (Eising 2017). Despite using different theories, concepts, and measurements, all studies reach the conclusion that ideological and positional alignments impact on the venues of domestic interest groups.

(2) A number of contributions add to the debate on how the EU affects state and non-state stakeholders in the EU member states and also outside the EU. Contributing to the study of the EU's impact on domestic actors, structures, and processes, they confirm that such Europeanisation can work in two ways, namely top-down and bottom-up (Börzel and Risse 2007). Several articles emphasise the topdown perspective and highlight the adaptation of domestic interest organisations to the EU's multilevel context: expanding beyond the EU borders, Cekik (2017) focuses on how the EU affects national interest groups and practices of interest mediation in accession countries. She informs readers on interest group populations in Macedonia, Montenegro, and Serbia, their membership in EU organisations and on how the EU shapes domestic structures in third countries. Surprisingly, she finds that there is no great difference regarding the Europeanisation of business and civil society interests in these three countries, which she attributes to the organisations' resource dependency structures and EU sponsorship of diffuse interests. She highlights that the accession countries have interest group systems that are distinct from those in the more established Western European member states. Kohler-Koch et al. (2017) scrutinise how national business associations in four countries adapt their access strategies to the EU multilevel system. By widening established models of the logic of access in EU policymaking, the authors demonstrate that the Europeanisation of business interests follows fairly similar patterns across countries. Resources, representativeness, and cross-sectoral scope matter in all national business systems. Furthermore, they conclude from their cross-national 
comparison that Central European - i.e. Polish - business groups do not adapt less well in terms of their access to domestic and EU institutions than their Western European counterparts. Tatham (2017) adds important findings on the regional offices in Brussels in terms of the activities they perform within the EU-level environment. Like the articles in the first section, he scrutinises the relevance of parties and party ideologies. He shows that even major party-political differences between regional and national governments do not leave much of an imprint on the activities of the regional offices in Brussels. This deviant finding - compared to those in the first section - may be due to the tighter coupling between regions and central governments than between domestic interest groups and national (government) parties, but may also result from focusing on the activity levels and general roles (as networkers, fund hunters, intermediaries, or policy players) of the regional offices in Brussels rather than on the regions' usage of venues at different levels.

(3) Employing frameworks rooted in the study of population ecology, two contributions tackle the question of bias in the EU interest group population. This classic subject in interest group research raises a fundamental question for democratic political orders: are some interests more strongly reflected in government decisions than others? It has drawn increasing attention in the study of interest representation in the EU in recent years (e.g. Beyers et al. 2008; Lowery et al. 2015) because of a concern that imbalances might increase due to the complexity of EU multilevel politics. The existing literature demonstrates that EU-level lobbying requires more resources than national lobbying, which biases political participation towards more resourceful groups. But empirical studies also suggest that the EU consultation regime and the Commission's practices of invitation to its expert groups effectively contain potential bias in favour of business (Bunea 2017; Rasmussen and Gross 2015). Moreover, contrary to common perceptions, the contributors to the special issue demonstrate that the EU-level interest group population resembles the populations of interest groups in the member states (Berkhout et al. 2017), when controlling, inter alia, for policy domains. The authors point out that a strong presence of business associations is a characteristic feature of the populations at both levels. They also suggest that business interest associations may have a larger representative capacity than other group types. In that respect, Kohler-Koch et al. (2017) find that domestic business interest associations (BIA) representing a larger share of their potential membership are more likely to have both access (rather than not) to the European Parliament and more frequent contacts with the Commission than BIAs that are less representative. Another contribution studies the 
population density of national interest groups in the EU, focusing on their presence in the European Parliament (Carroll and Rasmussen 2017). The authors find that countries with a greater number of national interest groups per MEP are among the oldest members of the $\mathrm{EU}$, underlining that a tradition of national interest group mobilisation may be a source of bias. This interpretation is held up by their finding that the presence of national groups in the EP is significantly affected by the associational culture prevalent within the country of origin.

The articles in this special issue are indicative of the move from case studies towards theory-based large- $N$ studies in EU and comparative interest group research. Several contributions (Carroll and Rasmussen 2017; Eising 2017; Eising et al. 2017) build on the INTEREURO project, ${ }^{1}$ in which issue-based (top-down) sampling served to study, from different perspectives, legislative lobbying on EU directive and regulation proposals for the population of organisations that were active on these proposals. Another large-scale project they draw on is the EUROLOB II project (Kohler-Koch et al. 2017), ${ }^{2}$ which analyses the strategies of British, German, French, and Polish interest groups in EU policy-making on the basis of the bottom-up sampling of national interest group directories. Marshall and Bernhagen (2017) use data collected within the Borderless Politics project, ${ }^{3}$ which analyses the political and social strategies of large business firms around the world. Other contributions are based on comprehensive surveys, website analyses, and content analyses scrutinising the EU impact on domestic interest organisations. Each article employs state-of-the-art research techniques and adapts them to the needs of interest group research. In line with the broadening of the field in recent years, the authors' findings are not only relevant to EU interest group studies but also address the literatures on multilevel governance, policy-making, Europeanisation, and political representation in the $\mathrm{EU}$, deepening our understanding of the functioning of advanced democracies and multilevel governance in Europe.

\section{An overview of the individual contributions}

The special issue is divided into three parts. The first section presents research on alignments of national interest organisations. The first contribution analyses how the alignments and arguments of domestic interest groups impact on their participation in national- and EU-level consultations on EU policies. The study covers interest organisations in the Netherlands, Sweden, Germany, Slovenia, and the UK (Eising et al. 2017). The authors test new hypotheses on the linkage between arguments and positional as well as ideological alignments and the national groups' strategic representation. Drawing on original data from research on $20 \mathrm{EU}$ directive proposals that were tabled between 2008 and 2010 by the European Commission, they use a large- $N$ study in which they include 
elaborate operationalisations of country and policy contexts, as well as group types. The authors provide evidence that alignments, positional and ideological, and arguments leave an imprint on the participation of domestic interests in consultations on EU policies. They identify four varieties of interest representation routines in response to different alignment patterns and conclude that the role of alignments and arguments can no longer be neglected in the analysis of political access and venue shopping in EU policy-making.

The second contribution in that section explores the lobbying strategies of large firms in EU policy-making (Marshall and Bernhagen 2017). In detail, the authors focus on large companies from Germany and Great Britain and investigate how their in-house lobbyists' perceptions of government-business relations and national systems of interest representation shape the firms' strategies in the multilevel system. They show that perceived conflict between firms and public authorities at the national level as well as greater conflict at the national level than at the EU level increase corporate lobbying at the EU level. The authors also find that national types of interest intermediation shape relative corporate engagement at the $\mathrm{EU}$ level as well as the readiness of firms to shift venue. Thereby, Marshall and Bernhagen contribute to studies which provide evidence that national institutional contexts continue to shape business political behaviour in the multilevel EU system, but in more complex ways than have previously been considered. Combined with the findings of Eising et al. (2017) and Wonka (2017), we see that alignments between decision-makers and interest groups must not be neglected when studying the interest groups' venue choices and relations with EU-level groups.

Shifting the perspective to the policy-makers, Wonka (2017) studies in detail the relations between members of the German parliament (Bundestag) and interest groups on issues related to EU policy-making. He situates their interactions in the context of the MPs' intra-party information exchanges and provides evidence putting into question exchange-based access theories. Moving away from the idea that information is a scarce resource for parliamentarians, Wonka provides evidence that information-gathering strategies of MPs in EU policy-making are systematically shaped by partisan ideologies and electoral incentives. Rather than screening diverse information delivered by a plethora of interest organisations, legislators strengthen the ties with those groups that are part of their core constituency and broadly share their political views. Here, in particular, Wonka finds that the model of information provision as a subsidy developed by Hall and Deardorff (2006) for the US context also holds for European policy-making in the German Bundestag. Wonka's contribution fills several research gaps, starting with an important new dataset from the perspective of politicians to his findings on information provision and ideological alignments.

Finally, building on Hirschman's distinction of loyalty, exit, and voice strategies, Eising (2017) studies the performance of EU-level interest groups with respect to their two core functions: the provision of policy information to their 
members and the formation of a common position to represent them in EU policy-making. Suggesting that full exit from EU-level groups is highly uncommon, he develops the category of selective exit to characterise the strategies of national interest organisations in response to a poor performance of EU associations. According to his findings, national members resort to voice within the EU-level groups and engage in coalitions and media debates outside them to counteract performance failures. In contrast to conventional wisdom, misalignments of national members' preferences with EU-level groups' common positions do not leave an imprint on the members' usage of inside strategies at national and EU levels.

The second section highlights the relevance of Europeanisation and the corresponding access of national interest organisations to political institutions in the EU multilevel system. Kohler et al. (2017) focus on the access of business interest associations to state institutions in Germany, Poland, France, the UK, and at EU level. The article compares the contact patterns of BIAs to national institutions with those to EU institutions, differentiating between executive and legislative institutions and between top-level politicians and bureaucrats at the working level. The authors further examine which factors explain similarities and differences in the selection of targets and the frequency of contacts. Broadening Bouwen's (2002) exchange-access model of interest intermediation in the EU, they provide evidence that more financial resources, greater mobilisation of potential members, and a wider sectoral scope tend to promote access. Contrary to earlier studies, the authors demonstrate that the economic importance of national sectors is not relevant to the access of BIAs to policy-makers.

Cekik (2017) asks how interest organisations outside the EU (Macedonia, Serbia, and Montenegro) have responded to the challenge of EU accession and their level of Europeanisation. Using survey data, she studies the interest groups' involvement in the EU accession process: groups' activities at the national level related to EU accession, their membership in EU-level associations, and contacts with EU institutions. As explanatory factors, she considers the groups' access to national institutions in domestic politics, their resources, the Europeanisation of policy areas and the groups' dependence on EU funding. Cekik finds that these factors account for interest groups' levels of Europeanisation, while variations across group types are insignificant. Her article fills an important research gap by analysing the role of interest organisations from EU accession countries, which have long been overlooked. In addition, she finds that national context characteristics as well as organisational structures like membership and access strategies account better for the Europeanisation of groups than their type of interest which contradicts the findings on grouptype effects in established EU member states.

In the third contribution to this section, Tatham (2017) explores the effects of organisational factors and domestic contexts on regional interest representation in the EU. The particular significance of his article for this special issue is an 
expansion of traditional understandings of interest representation to regional representations at the European level. These are rarely included in interest representation studies. Based on novel survey data for more than 100 regional offices, Tatham explores their roles and activities at the EU level. He seeks to account for their activities by linking them to office-level, regional and domestic contextual factors in a series of multilevel models. His results point out that younger regional representations are more geared to obtaining funding information and building ties with other regions than to engaging in legislative lobbying when compared to older, more established regional representations. His results show that a greater extent of self-rule in the region of origin is associated with a greater engagement in legislative lobbying at EU level. While many activities of the regional offices in Brussels are certainly geared to interest representation in the $\mathrm{EU}$, the author cautions that supranational mobilisation by domestic actors is not always aimed at obtaining policy influence.

The third and final section addresses the important question of representational bias existing within the population of interest organisations. Berkhout et al. (2017) analyse how the EU's population of interest organisations compares with those in EU member states. They explore a potential bias towards business representatives in the EU interest group population as well as the representational capacity of the organisations in the EU and national populations. The authors compare for the first time the EU-level interest group population with those in France, Great Britain, Germany, and the Netherlands, thus performing a comparison across distinct governance levels, European vs. national. They also account for different aspects of the diversity within the distinct interest group populations. The results show that the EU interest group population does not differ significantly from the national interest group populations, when controlling for other explanations such as policy domains, bringing new insights to studies on the EU interest group population ecology. This finding challenges accounts that see the EU as a special case, or characterise the EU interest group population as being uniquely biased towards business organisations.

Carroll and Rasmussen (2017) present a comprehensive study of the population of national interest groups lobbying the European Parliament (EP). In the first part of their analysis, the authors place the absolute number of organised interests in relation to different benchmarks such as the size of the national economy, population size, and the number of country seats in the EP. In the second part, they investigate how differences in domestic contexts condition the representation of national interest groups in the EP. Here, they take into account hitherto neglected national cultural resources (understood as the national associational culture). Their results show that countries with high levels of citizen activism have a greater number of groups present in the European Parliament, adding to studies that concentrate on national economic resources as a source of mobilisation. More generally, these findings enhance 
our understanding of how specific aspects of domestic contexts relate to the access of domestic interest organisations to EU institutions.

In sum, this special issue is a further step in the progression of comparative and EU interest group studies towards a field characterised by the systematic empirical testing of propositions derived from mid-range theories. With its focus on national interest groups in the EU multilevel system, it highlights a theoretically and empirically neglected research subject. Finally, it presents novel developments in the study of political alignments among interest groups and political institutions, the Europeanisation of domestic interest organisations, and the question of bias in interest group populations.

\section{Notes}

1. http://www.intereuro.eu.

2. http://www.mzes.uni-mannheim.de/d7/en/projects/eurolob-ii-europeanizationof-interest-intermediation.

3. http://www.abdn.ac.uk/research/borderlesspolitics/.

\section{Acknowledgements}

We thank the contributors to this special issue for both helpful comments and stimulating collaboration. Furthermore, we are indebted to C. Tönnissen and R. Sczepanski for manuscript preparation and technical support. We are grateful to several colleagues for their succinct reviews of the articles in this special issue. Special thanks go to A. Menon for his patience, persistence, and support during its preparation.

\section{Disclosure statement}

No potential conflict of interest was reported by the authors.

\section{Funding}

Our research was co-financed by the Deutsche Forschungsgemeinschaft [grant number EI 461/6-1] and the European Science Foundation project 10-ECRP-008: Comparative Research on Interest Group Politics in Europe (INTEREURO). The workshop held in preparation of this special issue was funded by the Fritz-Thyssen-Foundation (Az. 30.16.0.004 IB). 


\section{References}

Allern, Elin, and Tim Bale (2012). 'Political Parties and Interest Groups: Disentangling Complex Relationships', Party Politics, 18:1, 7-25.

Baumgartner, Frank, and Beth Leech (1998). Basic Interests: The Importance of Groups in Politics and Political Science. Princeton: Princeton University Press.

Baumgartner, Frank, Jeffrey M. Berry, Marie Hojnacki, Beth L. Leech, and David C. Kimball (2009). Lobbying and Policy Change: Who Wins, Who Loses, and Why. Chicago, IL: University of Chicago Press.

Berkhout, Joost, Marcel Hanegraaff, and Caelesta Braun (2017). 'Is the EU Different? Comparing the Diversity of National and EU Level-Systems of Interest Organizations', West European Politics, doi: 10.1080/01402382.2017.1308695.

Bernhagen, Patrick, and Neil J. Mitchell (2009). 'The Determinants of Direct Corporate Lobbying in the European Union', European Union Politics, 10:2, 155-176.

Beyers, Jan, and Bart Kerremans (2007). 'Critical Resource Dependencies and the Europeanization of Domestic Interest Groups', Journal of European Public Policy, 14:3, 460-481.

Beyers, Jan, Rainer Eising, and William Maloney (2008). 'Researching Interest Group Politics in Europe and Elsewhere: Much We Study, Little We Know?', West European Politics, 31:6, 1103-1128.

Beyers, Jan, Laura Chaqués Bonafont, Andreas Dür, Rainer Eising, Danica Fink-Hafner, David Lowery, Christine Mahoney, William Maloney, and Daniel Naurin (2014). 'The INTEREURO Project: Logic and Structure', Interest Groups \& Advocacy, 3:2, 126-140.

Beyers, Jan, Iskander De Bruycker, and Inger Baller (2015). 'The Alignment of Parties and Interest Groups in EU Legislative Politics: A Tale of Two Different Worlds?', Journal of European Public Policy, 22:4, 534-551.

Binderkrantz, Anne (2003). 'Strategies of Influence: How Interest Organizations React to Changes in Parliamentary Influence and Activity', Scandinavian Political Studies, 26:4, 287-305.

Binderkrantz, Anne, Peter Munk Christiansen, and Helene Helboe Pedersen (2015). 'Interest Group Access to the Bureaucracy, Parliament and the Media', Governance, 28:1, 95-112.

Börzel, Tanja A., and Thomas Risse (2007). 'Europeanization: The Domestic Impact of EU Politics', in Knud Jørgensen, Mark Pollack and Ben J. Rosamond (eds.), The Sage Handbook of European Union Politics. London: Sage, 483-504.

Bouwen, Peter (2002). 'Corporate Lobbying in the European Union: The Logic of Access', Journal of European Public Policy, 9:3, 365-390. 
Bunea, Adriana (2017). 'Designing Stakeholder Consultation: Reinforcing or Alleviating Bias in European Union System of Governance', European Journal of Political Research, 56:1, 46-69.

Bunea, Adriana, and Frank Baumgartner (2014). 'The State of the Discipline: Authorship, Research Designs, and Citation Patterns in Studies of EU Interest Groups and Lobbying', Journal of European Public Policy, 21:10, 1412-1434.

Carroll, Brendan, and Anne Rasmussen (2017). 'Cultural Capital and the Lobbying the Density of Organized Interests European Parliament', West European Politics, doi: 10.1080/01402382.2017.1303243.

Cekik, Aneta (2017). 'Adapting to Europe? Business Interests and Civil Society Groups in Accession Countries', West European Politics, doi: 10.1080/01402382.2017.1308696.

Chalmers, Adam (2013). 'Trading Information for Access: Informational Lobbying Strategies and Interest Group Access to the European Union, Journal of European Public Policy, 20:1, 39-58.

Coen, David, and Alexander Katsaitis (2013). 'Chameleon Pluralism in the EU: An Empirical Study of the European Commission Interest Group Density and Diversity across Policy Domains', Journal of European Public Policy, 20:8, 1104-1119.

Culpepper, Pepper D. (2011). Quiet Politics and Business Power: Corporate Control in Europe and Japan. Cambridge: Cambridge University Press.

Dür, Andreas, and Dirk De Bièvre (2007). 'The Question of Interest Group Influence', Journal of Public Policy, 27:1, 1-12.

Dür, Andreas, and Gemma Mateo (2016). Insiders versus Outsiders. Interest Group Politics in Multilevel Europe. Oxford: Oxford University Press.

Dür, Andreas, Patrick Bernhagen, and David Marshall (2015). 'Interest Group Success in the European Union: When (and Why) Does Business Lose?', Comparative Political Studies, 48, 1-33. first published online, doi: 10.1177/0010414014565890.

Eising, Rainer (2007). 'Institutional Context, Organizational Resources and Strategic Choices: Explaining Interest Group Access in the European Union', European Union Politics, 8:3, 329-362.

Eising, Rainer (2016). 'Studying Interest Groups: Methodological Challenges and Tools', European Political Science, 1-15, doi:10.1057/eps.2016.14 (accessed 24 November 2016).

Eising, Rainer (2017). 'Imperfect Public Goods and the Logic of Selective Exit in EU Interest Organizations', West European Politics, doi: 10.1080/01402382.2017.1320173.

Eising, Rainer, and Beate Kohler-Koch (1994). 'Inflation und Zerfaserung: Trends der Interessenvermittlung in der Europäischen Gemeinschaft', in Wolfgang Streeck (ed.), Staat und Verbände. Opladen: Westdeutscher Verlag, 175-206.

Eising, Rainer, Daniel Rasch, Patrycja Rozbicka, Danica Fink-Hafner, Mitja Hafner-Fink, and Meta Novak (2017). 'Who Says What to Whom? Alignments and Arguments in EU Policy-Making', West European Politics, doi: 10.1080/01402382.2017.1320175.

Esping-Andersen, Gösta (1990). The Three Worlds of Welfare Capitalism. Cambridge: Cambridge University Press.

Gornitzka, Åse, and Ulf Sverdrup (2008). 'Who Consults? The Configuration of Expert Groups in the European Union', West European Politics, 31:4, 725-750.

Hall, Richard L., and Alan V. Deardorff (2006). 'Lobbying as Legislative Subsidy', American Political Science Review, 100:1, 69-84.

Hall, Peter, and David Soskice (2001). Varieties of Capitalism. the Institutional Foundations of Comparative Advantage. Oxford: Oxford University Press.

Hojnacki, Marie, and David C. Kimball (1998). 'Organized Interests and the Decision of Whom to Lobby in Congress', American Political Science Review, 92:4, 775-790. 
Klüver, Heike (2011). 'The Contextual Nature of Lobbying: Explaining Lobbying Success in the European Union', European Union Politics, 12:4, 483-506.

Klüver, Heike, Caelesta Braun, and Jan Beyers (2015). 'Legislative Lobbying in Context: Towards a Conceptual Framework of Interest Group Lobbying in the European Union', Journal of European Public Policy, 22:4, 447-461.

Knodt, Michele, Justin Greenwood, and Christine Quittkat (2011). 'Territorial and Functional Interest Representation in EU Governance', Journal of European Integration, 33:4, 349-367.

Kohler-Koch, Beate, Peter Kotzian, and Christine Quittkat (2017). 'The Multi-Level Interest Representation of National Business Associations', West European Politics, doi: 10.1080/01402382.2017.1303244.

Kreutler, Maren (2014). Interest Group Coalitions in the European Union. an Analysis of (in)Formal Initiatives to Influence European Energy Policy. Baden-Baden: Nomos.

Lowery, David, Frank R. Baumgartner, Joost Berkhout, Jeffrey M. Berry, Darren Halpin, Marie Hojnacki, Heike Klüver, Beate Kohler-Koch, Jeremy Richardson, and Kay Lehman Schlozman (2015). 'Images of an Unbiased Interest System', Journal of European Public Policy, 22:8, 1212-1231.

Lowi, Theodore (1972). "Four Systems of Policy, Politics and Choice, Public Administration Review, 32:4, 298-310.

Mahoney, Christine (2008). Brussels vs. The Beltway: Advocacy in the United States and the European Union. Washington, D.C.: Georgetown University Press.

Marshall, David, and Patrick Bernhagen (2017). 'Government-Business Relations in Multi-Level Systems: The Effect of Conflict Perception on Venue Choice', West European Politics, doi: 10.1080/01402382.2017.1303245.

Olson, Mancur (1965). The Logic of Collective Action. Public Goods and the Theory of Groups. Cambridge: Harvard University Press.

Rasmussen, Maja Kluger (2015). 'The Battle for Influence: The Politics of Business Lobbying in the European Parliament', Journal of Common Market Studies, 53:2, 365-382.

Rasmussen, Anne, and Vlad Gross (2015). "Biased Access? Exploring Selection to Advisory Committees', European Political Science Review, 7:3, 343-372.

Rasmussen, Anne, Brendan J. Carroll, and David Lowery (2014). 'Representatives of the Public? Public Opinion and Interest Group Activity', European Journal of Political Research, 53:2, 250-268.

Schneider, Gerald, Daniel Finke, and Konstantin Baltz (2007). 'With a Little Help from the State: Interest Intermediation in the Domestic Pre-Negotiations of EU Legislation', Journal of European Public Policy, 14:3, 444-459.

Siaroff, Alan (1999). 'Corporatism in 24 Industrial Democracies: Meaning and Measurement', European Journal of Political Research, 36:2, 175-205.

Tatham, Michael (2017). 'Networkers, Fund Hunters, Intermediaries, or Policy Players? The Activities of Regions in Brussels', West European Politics, doi: 10.1080/01402382.2017.1303246.

Vogel, David (1989). Fluctuating Fortunes: The Political Power of Business in America. New York, NY: Basic Books.

Vogel, David (1995). Trading up: Consumer and Environmental Regulation in a Global Economy. Harvard: Harvard University Press.

Wonka, Arndt (2017). 'German MPs and Interest Groups in EU Multilevel PolicyMaking: The Politics of Information Exchange', West European Politics, doi: 10.1080/01402382.2017.1303247. 


\title{
Who says what to whom? Alignments and arguments in EU policy-making
}

\author{
Rainer Eising, Daniel Rasch, Patrycja Rozbicka, Danica Fink-Hafner, \\ Mitja Hafner-Fink and Meta Novak
}

\begin{abstract}
In the EU multilevel polity, domestic interest groups seek to shape EU legislation by accessing both national and EU institutions. Previous studies indicated that institutional and issue contexts as well as organisational characteristics shape their strategies of interest representation. However, we know much less about how alignments and arguments impact on their participation in EU and national policy consultations. Addressing this gap, we investigate the lobbying strategies of almost 2900 national interest organisations from five member states (Germany, the Netherlands, Slovenia, Sweden, and the United Kingdom) on 20 EU directive proposals also bringing a new empirical scope to the study of multilevel interest representation. The findings indicate that alignments and arguments shape the participation of domestic interest groups in consultations on EU policies. We infer from our study that some general predictions of interest group behaviour are overstretched and outline four major variations of interest representation routines.
\end{abstract}

In European Union policy-making, domestic interest organisations articulate their demands not only vis-à-vis national institutions but increasingly also at the European level vis-à-vis the EU institutions (Hooghe and Marks 2001). Several studies have highlighted that the groups' lobbying activities are linked to their organisational characteristics (Eising 2004), their embeddedness in domestic contexts and multilevel networks (Beyers and Kerremans 2012; Kriesi et al. 2007), as well as the features of policy issues (Dür and Mateo 2016). These studies yielded important insights, but fail to account for a considerable extent of the observed variation in multilevel interest representation. 
To narrow this research gap, we include potentially important issue-specific aspects of interest representation in EU policy-making in our study, focusing on how national interest groups' arguments and alignments with state institutions impact on their venue choices. Studies on groups' alignments with political institutions and argumentation patterns in a relation to multi-venue shopping are still a rarity, but we already see some useful insights. Hojnacki and Kimball (1998) and Hall and Deardorff (2006) indicated that groups seek access to like-minded politicians. Baumgartner and Jones (1993) pointed out that interest groups prefer venues that are more open to their demands and adjust the presentation of their arguments accordingly. Beyers et al. (2015) demonstrate that business interests are more closely aligned with rightist parties in the European Parliament (EP), and that civil society groups are more closely aligned with leftist political parties. Adding to this literature, we scrutinise how their alignments and arguments impact on domestic groups participation in EU-level and national consultations.

Our contribution to the debate on the interest groups' venue shopping is twofold. In theoretical terms, we present and test new hypotheses on how arguments and alignments impact on multilevel interest representation. We demonstrate not only that these factors have a significant impact on the choice of interest groups to which they provide policy information but also identify systematic coping strategies with different alignment patterns. Empirically, we study 2900 national interest groups from five countries that were vocal on 20 EU directive proposals which the European Commission tabled between 2008 and 2010. Including also nuanced controls for country and policy contexts as well as organisational types, we thus respond to the call for more rigorous empirical theory testing in EU interest group and policy studies (Beyers et al. 2014; Bunea and Baumgartner 2014).

First, we review the literature to establish our hypotheses about the association between the interest groups' participation in policy consultations and their arguments and alignments. The next section outlines the research design and data. The following empirical analysis indicates how the route selection relates to positional and ideological alignments and expressed arguments.

\section{Domestic interest organisations and their venue selection: the relevance of alignments and arguments}

We study which factors cause national interest organisations to participate in consultations on EU policy proposals. In recent years, several empirical studies scrutinised the lobbying strategies of these organisations (e.g. Beyers and Kerremans 2012; Dür and Mateo 2016; Klüver 2013). These studies find that the national route is still the major route of national interest groups. While membership in EU-level interest groups is a central element in their interest representation strategy (e.g. Eising 2017), it is less common for them to voice 
their interests directly vis-à-vis the EU institutions. According to these studies, institutional contexts (such as the domestic modes of interest representation), policy contexts (e.g. distributive vs. regulatory policies) and issue characteristics (political or technical, degree of salience, extent of Europeanisation) as well as interest group features (type of interest group, financial resources, membership base) account for variations in the representation of interests in the EU's multilevel system. While yielding a number of important insights, their emphasis on institutional and organisational characteristics as well as particular attributes of issues has neglected alignments and arguments.

We expand on these analyses by studying potentially important issuespecific aspects of EU policy debates. We conjecture that, to an important degree, alignments and arguments account for the variability of venue selection in the EU multilevel system. The notion of interest groups' alignments with political institutions is rooted in the study of voters and parties according to which citizens cast their vote for parties based on their proximity to the parties' ideological positions (see Kitschelt and Wilkinson 2007). Transferring the idea of alignments to the study of legislative lobbying necessitates some modifications because here interest groups do not elect political representatives for the next term but seek to impact on legislation. And as executive institutions rather than political parties tend to be their main interlocutors in EU legislation, we focus on interest groups' alignments with the European Commission that proposes EU legislation and with national governments that handle it in the domestic contexts and whose ministers decide on it within the EU Council. We distinguish among two kinds of alignments: positional alignments and ideological alignments. ${ }^{1}$

Ideological alignments relate to general programmatic positions, ideas, and values of actors on politics (Gerring 2001: 71-80). Several authors (e.g. MüllerRommel 1988) suggest the ideological proximity of certain types of interests with specific party families on the left-right dimension - i.e. trade unions with social democratic parties and business interests with conservative, Christian democratic, or liberal parties. Given the prevalence of the left-right dimension in the EU member states, it is well suited to studying the ideological alignments among interest groups and political institutions in EU policy-making (see also Beyers et al. 2015). Ideological alignments referring to the proximity of interest groups and political institutions on the left-right dimension are at the heart of lasting relations and durable alliances among these actors.

Referring to the congruence of different actors' positions on the issues in a policy proposal, positional alignments are prone to short-term fluctuations and ad hoc coalitions. We distinguish three general types of positions that an actor may hold on an EU policy proposal: opposed, supportive, or unclear/ neutral. Our analysis will focus on two kinds of positional alignments and two kinds of misalignments, leaving out more ambiguous relations as these have less clear implications for venue shopping: Two actors A and B have either the 
same position on an incoming Commission proposal (A and B support it or $\mathrm{A}$ and $\mathrm{B}$ oppose it) or they have contrary positions (A[B] supports it and $\mathrm{B}[\mathrm{A}]$ opposes it). Accordingly, aligned actors hold the same position on a policy proposal, whereas misaligned actors hold opposite positions on it. Given our focus on legislative lobbying, we expect that positional alignments will be more important to interest groups' venue shopping than ideological alignments.

Major studies of interest representation argue that interest groups seek out venues that are open to their demands (Baumgartner and Jones 1993; Hojnacki and Kimball 1998). Hall and Deardorff (2006) suggest that many groups prioritise contacts with like-minded politicians and provide information as a 'subsidy' to them because these advance their objectives in the best possible way. In multilevel systems, they will concentrate their efforts on the institutional layer that appears to be more amenable to their demands. In the EU multi-level system, the preferred venue of domestic interest groups depends not only on the alignment between their own and the national government's positions but also on that with the European Commission's position. Therefore, we test the hypothesis:

Hypothesis 1. National groups that support a Commission proposal are more vocal in EU-level consultations than national groups that oppose it.

If the national government as its most important addressee in EU policy-making takes a contrary position on EU legislation, an interest group needs to look for alternatives. In the parliamentary democracies of the EU member states, it is almost impossible for such a group to convince the national parliaments to reverse the government's position because the majority parties keep government in power (except for minority governments which are common in Denmark and Sweden). In these circumstances, groups will participate more frequently in EU-level consultations to impact on EU legislation (see also Marshall and Bernhagen 2017):

Hypothesis 2. National interest groups holding a different position on the Commission proposal than the national government are more vocal in EU-level consultations.

Ideological alignments may be as important as positional alignments because interest representation

is not just an ad hoc affair which starts when salient issues appear on the agenda, but an ongoing endeavour to establish social recognition and smooth-working relations, all of which prepares the ground for exerting influence on a more persistent basis. (Kohler-Koch et al. 2017)

Establishing lasting relations with government and parliament will depend on the ideological outlook of these institutions. According to the party difference account of welfare state policies (e.g. Schmidt 1996), left-wing parties are (still) more prepared to engage in market and social regulation than conservative or liberal parties. The traditional proximity of trade unions to social democratic 
parties and that of business interests to liberal and Christian democratic or conservative parties prove the point (e.g. Müller-Rommel 1988). It follows that business interest groups should have greater access to more conservative governments and may exit to the EU level when facing a leftist government (see Bartolini 2005 on the exit option).

Hypothesis 3. Business interests are more inclined to participate in EU-level consultations when facing a left-wing majority in the national parliament.

The venues of interest organisations may also depend on the receptiveness of political institutions to their arguments (Majone 1989). We define an argument after Ball (1995: 3) as an 'oral or written statement that advocates adopting a policy or justifies the decision to adopt a policy'. Actors in EU policy processes present arguments to substantiate their claims. As national and European decision-makers are unable to predict all potential effects of planned policies, they are in need of external information to reduce uncertainties, learn about alternatives, improve their problem-solving capacity, and win stakeholder support. Different policy-making institutions will be interested in different types of information (Bouwen 2002). Bureaucrats are said to seek technical information whereas politicians depend on political information, for example about constituency support (Beyers and Kerremans 2012; Dür and Mateo 2016).

We transfer the general idea to the presentation of arguments at different levels in the EU multilevel system. We assume that national interest groups present their arguments on an EU policy proposal to the national government which is their main contact in EU policy-making and able to represent them in the EU Council. However, domestic interest groups may emphasise different aspects of EU policy proposals (Eising et al. 2015; Klüver 2013) and present those more fervently at EU level that highlight profound repercussions of EU policies or to which EU institutions would seem to be more amenable than national institutions. We explore this proposition for arguments referring to expert evidence, costs and benefits, rights, national interests, and EU public interests.

International policy studies have drawn attention to the increasing role of scientific evidence provided by experts in public policy-making (Haas 1992). Given the complexity of EU policy problems, both national and EU-level institutions require scientific evidence when developing EU policy goals and instruments. Experts who provide such information on technical, legal, economic, or financial aspects help them to better assess the problem-solving capacity and feasibility of the debated policy options and instruments. This has already been shown in access-related studies (Chalmers 2013) as well as comparative studies between the US and EU advocacy systems (Mahoney 2008).

Hypothesis $4 a$. National interest groups will present expert evidence in national and in EU-level consultations. 
Classic policy studies emphasise the importance of cost-benefit calculations for the stance of actors on policy proposals (Lowi 1972). The bulk of EU policies are about market integration and the corresponding market and social regulation. The abolishment of barriers to the free movement of persons, goods, capital, and services is grounded in economic arguments highlighting not only welfare but also major distributional effects (European Commission 1985: 12). Given the centrality of the distribution of costs and benefits across member states, economic actors, and social classes to the justification of the EU's core policies, these are a major subject in the EU-level debates on incoming legislation. Accordingly:

Hypothesis $4 b$. National interest groups emphasising costs and benefits participate more frequently in EU-level consultations than those that do not name them.

EU policies reallocate rights and obligations across citizens, consumers, professionals, institutions, and firms, both across and within member states. The rights EU policies confer or take away vary tremendously. They can relate to economic issues such as market access, entitle EU citizens to obtain health treatment in other member states, limit the abilities of researchers to use animals in experiments, or grant refugees more support in court procedures, to name only some of the issues in the studied directive proposals. Obviously, the conferral or abolition of rights can entail frictions for domestic political systems and trigger domestic contestation. The conferral of new rights to them will lead many actors to move to Brussels to support the Commission's course of action where others will seek to move EU legislation in the opposite direction. Thus:

Hypothesis $4 c$. National interest groups claiming rights participate more often in EU-level consultations than those that do not.

Not only interest group scholars (e.g. Bouwen 2002; Tatham 2017) stress the relevance of territorial interests in EU policy-making. EU policies must be applied throughout the union's 28 member states and vary in their goodness of fit with national policy legacies, administrative settings, etc. (e.g. Risse et al. 2001). Therefore, information about member states' interests in incoming EU legislation is indispensable to the European Commission. However, for two reasons references to national interests provided by interest organisations should be more appreciated in national consultations than in EU-level consultations. First, in EU legislation, the EU Council - rather than domestic interest groups - is the main channel for advocating national interests. Second, given their accountability to domestic voters, national governments would seem more responsive than the European Commission to interest groups articulating national interests.

Hypothesis $4 d$. Interest groups stressing national interests will be more present in domestic consultations than those that do not stress to them.

In contrast, national interest groups emphasising the relevance of EU policies for European public interests would seem to address the European Commission 
and the European Parliament to complement their routinely conducted national-level activities. This way, they respond directly to the aims of the European Commission (to promote the general interest of the Union and take appropriate initiatives to that end, Article 17(1) TEU), and the European Parliament (that represents citizens directly at the Union level, Article 10(2) TEU).

Hypothesis $4 e$. National interest groups referring to EU public interests participate more frequently in EU-level consultations than those that do not refer to them.

\section{Control variables}

We include national contexts, policy characteristics, and organisational types as controls. National systems of interest mediation may impact on venue shopping (Marshall and Bernhagen 2017). As groups from corporatist countries rely to a greater extent on national concertation than those from pluralistic countries, the latter should be more visible in the EU arena. We measure corporatism by means of a composite index indicating the centralisation of wage setting, trade union density, and collective bargaining coverage rates (see Vatter and Bernauer 2009). We also control for national wealth by including the logged gross domestic product (GDP)/capita of each member state in 2008 in the analysis, expecting that actors situated in wealthier contexts find it easier to participate in consultations (Carroll and Rasmussen 2017).

From policy studies we take the insight that policy characteristics may impact on interest representation. On the one hand, we control for analytical categories developed in policy studies. We distinguish among distributive and regulatory policies (Lowi 1972) and also separate business regulation from general regulation and public sector regulation (Binderkrantz et al. 2014). We expect more interest group activity in regulatory policy and business regulation because these include the bulk of EU legislation. We also control for if the directive proposal is a novel or a recast proposal because in the latter case many interest organisations can build on previous mobilisation experiences which should facilitate the participation in policy consultations. According to Dür and Mateo (2016), interest groups should be more active in policy areas in which the EU has greater powers. To indicate the Europeanisation of policy areas, we draw on Börzel's (2006) measure for the policy breadth of the EU. However, national groups may not simply follow the competence allocation of the EU treaties but address mostly those political institutions which they find should do something to resolve the policy problem. Accordingly, we control for if groups find that the national government or the European Commission should resolve the policy problem at hand.

On other hand, based on the categories of the Policy Agendas project (http:// www.comparativeagendas.net/), we include two substantial policy areas that are characteristic for EU policy-making in the late 2000s to probe if these 
account additionally for the venues national interest groups seek out. In both policy areas, we retrieved a substantial number of actors: in banking, finance, and domestic commerce 703 actors and in environmental policy 1471 actors. Both policy areas vary across the type and length of EU intervention as well as national legislative traditions, which impacts substantially on the implementation of EU policies (Haverland et al. 2011).

Finally, different types of interest may have different organisational capacities. Based on the Olsonian logic of collective action (Olson 1965), business interest groups as specific interests should be more involved in policy consultations than civil society groups as diffuse interests. We present the descriptive statistics of all variables in Table 1.

\section{Research design and data}

Our analysis is part of the wider INTEREURO project on interest group representation in Europe (Beyers et al. 2014). Building on issue-based sampling we study the participation of domestic interest groups in national and EU-level consultations on $20 \mathrm{EU}$ directive proposals which the European Commission tabled between 2008 and 2010. After placing all tabled proposals in these years in a random order and moving downwards from the top of the list, a proposal needed to be covered in at least one out of two EU-level print media (Agence Europe, European Voice) and two out of three national print media (Le Monde, Frankfurter Allgemeine Zeitung, Financial Times) to make sure that it drew attention and was debated at both national and EU levels. We used Englishand non-English-language newspapers to avoid a bias towards British actors. In each newspaper article, the coverage of a directive had to amount to at least five rows of reporting. As a result, our study includes a set of directives in the EU's energy and climate package, some directives in EU financial market regulation, some aspects of social regulation such as child protection, animal welfare, and asylum seekers' legal rights, such that a broad variety of EU policy areas is covered.

We study national interest groups from five EU member states: Germany, the Netherlands, Slovenia, Sweden, and the United Kingdom. This selection of countries controls some national characteristics and while ensuring variation with respect to national wealth, state interest group models, and governing party ideologies. The per capita income in Germany, Sweden, the United Kingdom, and the Netherlands is well above the EU average whereas that of Slovenia is below it. The United Kingdom exemplifies the pluralistic countries while the other four countries are instances of corporatism. The ideological outlook of the parliamentary majorities in these countries differed when the Commission presented its proposals. Due to these differences, we expect the participation of domestic interest groups in the policy consultations to vary across countries. 
Table 1. Variable definitions and descriptive statistics $(N=596)$.

\begin{tabular}{|c|c|c|c|c|c|}
\hline Variable & & Mean & SD & Min & Max \\
\hline Consultations & $\begin{array}{l}\text { 0 No participation; } 1 \text { National consultation } \\
\text { (ref.); } 2 \text { EU consultations; } 3 \text { National and } \\
\text { EU consultations }\end{array}$ & 1.418 & 0.992 & 0 & 3 \\
\hline GDP/Capita(log) & Member states GDP/Capita (log) in 2008 & 3.531 & 0.110 & 3.43 & 3.66 \\
\hline Corporatism & $\begin{array}{l}\text { Index of corporatism: sum of standardised } \\
\text { scores for centralisation of wage setting } \\
(1-3) \text {, trade union density (0-100) and } \\
\text { collective bargaining coverage }(0-100) \text {. } \\
\text { Negative values indicate pluralism and } \\
\text { positive values corporatism }\end{array}$ & 0.279 & 1.861 & -2.49 & 3.82 \\
\hline RILE & $\begin{array}{l}\text { Right-left index weighted according to } \\
\text { parties' national vote shares. Negative } \\
\text { values indicate a leftist majority and } \\
\text { positive values a conservative majority of } \\
\text { manifesto statements on a scale ranging } \\
\text { from }-100 \text { to } 100\end{array}$ & 3.080 & 5.753 & -9.89 & 7.60 \\
\hline Civil society group & $\begin{array}{l}1 \text { Civic group; } 0 \text { Firm, trade union, profes- } \\
\text { sional group, research institute, institu- } \\
\text { tion, local or regional authority }\end{array}$ & 0.141 & 0.348 & 0 & 1 \\
\hline Business group & $\begin{array}{l}1 \text { Business interest group; } 0 \text { Firm, trade un- } \\
\text { ion, professional group, research institute, } \\
\text { institution, local or regional authority }\end{array}$ & 0.269 & 0.444 & 0 & 1 \\
\hline $\begin{array}{l}\text { RILE*Business } \\
\text { group }\end{array}$ & $\begin{array}{l}\text { Interaction between RILE and business } \\
\text { group }\end{array}$ & 0.449 & 3.524 & -9.89 & 7.60 \\
\hline Environment & $\begin{array}{l}1 \text { Environmental policy; } 0 \text { Other policy } \\
\text { areas }\end{array}$ & 0.446 & 0.498 & 0 & 1 \\
\hline Banking & $\begin{array}{l}1 \text { Banking, finance, and domestic com- } \\
\text { merce; } 0 \text { Other policy areas }\end{array}$ & 0.174 & 0.380 & 0 & 1 \\
\hline Recast & 1 Recast directive; 0 No recast directive & 0.221 & 0.416 & 0 & 1 \\
\hline Regulatory policy & 1 Regulatory policy; 0 Distributive policy & 0.944 & 0.229 & 0 & 1 \\
\hline General regulation & 1 General regulation; 0 Business regulation & 0.121 & 0.326 & 0 & 1 \\
\hline $\begin{array}{l}\text { Public sector } \\
\text { regulation }\end{array}$ & $\begin{array}{l}1 \text { Public sector regulation; } 0 \text { Business } \\
\text { regulation }\end{array}$ & 0.193 & 0.395 & 0 & 1 \\
\hline $\begin{array}{l}\text { Europeanisation of } \\
\text { policy area }\end{array}$ & $\begin{array}{l}1 \text { Only national powers in the policy area; } \\
2 \text { Mostly national powers; } 3 \text { National and } \\
\text { EU powers; } 4 \text { Mostly EU powers; } 5 \text { Only } \\
\text { EU powers }\end{array}$ & 3.731 & 0.621 & 1.5 & 4 \\
\hline $\begin{array}{l}\text { Interest group po- } \\
\text { sition opposed }\end{array}$ & $\begin{array}{l}1 \text { IG opposed to Commission proposal; } 0 \text { IG } \\
\text { neutral or ambiguous }\end{array}$ & 0.228 & 0.420 & 0 & 1 \\
\hline $\begin{array}{l}\text { Interest group po- } \\
\text { sition supportive }\end{array}$ & $\begin{array}{l}1 \text { IG support of Commission proposal; } 0 \text { IG } \\
\text { neutral or ambiguous }\end{array}$ & 0.482 & 0.500 & 0 & 1 \\
\hline $\begin{array}{l}\text { Government posi- } \\
\text { tion opposed }\end{array}$ & $\begin{array}{l}1 \text { Government opposed to Commission } \\
\text { proposal; } 0 \text { Government neutral or } \\
\text { ambiguous }\end{array}$ & 0.138 & 0.345 & 0 & 1 \\
\hline $\begin{array}{l}\text { Government posi- } \\
\text { tion supportive }\end{array}$ & $\begin{array}{l}1 \text { Government support for Commission } \\
\text { proposal; } 0 \text { Government neutral or } \\
\text { ambiguous }\end{array}$ & 0.559 & 0.497 & 0 & 1 \\
\hline Rights & $\begin{array}{l}1 \text { According to the author of the text the } \\
\text { essence of this proposal at a macro level } \\
\text { is rights; } 0 \text { The essence of the proposal is } \\
\text { not about rights }\end{array}$ & 0.106 & 0.308 & 0 & 1 \\
\hline Evidence & $\begin{array}{l}1 \text { The arguments refer to evidence gen- } \\
\text { erated by experts or in expert groups; } \\
\text { 0 The arguments do not refer to expert } \\
\text { evidence }\end{array}$ & 0.404 & 0.491 & 0 & 1 \\
\hline Costs and benefits & $\begin{array}{l}1 \text { The arguments point to the distribution } \\
\text { of costs or benefits; } 0 \text { The arguments do } \\
\text { not point to the distribution of costs or } \\
\text { benefits }\end{array}$ & 0.436 & 0.496 & 0 & 1 \\
\hline
\end{tabular}


Table 1. (Continued).

\begin{tabular}{|c|c|c|c|c|c|}
\hline Variable & & Mean & SD & Min & Max \\
\hline National interest & $\begin{array}{l}1 \text { The arguments reference national } \\
\text { interests of the EU member states; 0 The } \\
\text { arguments do not reference national } \\
\text { interests of the EU member states }\end{array}$ & 0.188 & 0.391 & 0 & 1 \\
\hline EU public interests & $\begin{array}{l}1 \text { The arguments reference the interests of } \\
\text { the European public (the EU citizens at } \\
\text { large, referring to individuals in potential- } \\
\text { ly large number); 0 The arguments do not } \\
\text { reference the interests of the European } \\
\text { public }\end{array}$ & 0.238 & 0.426 & 0 & 1 \\
\hline $\begin{array}{l}\text { European } \\
\text { Commission: do } \\
\text { something }\end{array}$ & $\begin{array}{l}1 \text { The European Commission should do } \\
\text { something about the policy problem; } 0 \\
\text { The European Commission is not named }\end{array}$ & 0.223 & 0.417 & 0 & 1 \\
\hline $\begin{array}{l}\text { National gov- } \\
\text { ernment: do } \\
\text { something }\end{array}$ & $\begin{array}{l}1 \text { The national government should do } \\
\text { something about the policy problem; } 0 \\
\text { The national government is not named }\end{array}$ & 0.190 & 0.392 & 0 & 1 \\
\hline
\end{tabular}

In line with the advice to identify the full population of actors involved in legislative lobbying (e.g. Eising 2016), we proceeded in four steps. We coded the actors mentioned in the media articles used for the sampling of directives as well as in two daily newspapers placed on different sides of the left-right continuum in each of our five countries. ${ }^{2}$ We also checked the official EU and national consultation data on each directive proposal using the webpages of the national ministries and parliaments, the Commission's consultation webpage 'Your Voice in Europe', the consultation data provided by its Directorates General, as well as the EUR-Lex data. Then, we searched the web for additional actors. Finally, interviews with EU and national officials as well as interest organisations yielded an additional set of actors.

In total, we identified about 4700 unique public and private actors. More than 1600 actors were present in more than one policy debate. A large variety of domestic actors voiced their opinion in the policy debates. We found 2899 non-state actors from the five countries: 391 civil society groups (13.5\% of all studied actors), 57 trade unions (2.0\%), 178 professional associations (6.1\%), 607 business interest groups 20.9\%), 803 firms (27.1\%), 219 research institutes (7.6\%), 383 institutions (13.2\%), and 261 local and regional authorities (9.0\%). Not all retrieved groups participated in policy consultations. Some were only mentioned in the media, presented comments on their web pages, or were named by our interview partners.

Even though they are not held for each and every policy proposal in the EU, we study the participation in consultations for the following reasons. First, the EU holds policy consultations on the major directive proposals and these are a useful point of departure for sampling the involved actors. As the barrier to entry is fairly low, almost all actors with a stake in the proposal are able to participate in these consultations and present their positions to EU decision-makers (see Bunea 2017: 65). Moreover, in many consultations the 
Table 2. The participation of domestic interest organisations in consultations on EU policies: multinomial logit regressions.

\begin{tabular}{|c|c|c|c|}
\hline Variables & Model 1a & Model 1b & Model 2 \\
\hline \multicolumn{4}{|l|}{ EU-level consultations only } \\
\hline GDP per capita (Log) & $-7.218^{* * *}$ & $-9.064^{* * *}$ & $-11.411^{* * *}$ \\
\hline Corporatism & 0.050 & $0.127^{*}$ & -0.152 \\
\hline RILE & 0.025 & 0.032 & $-0.201^{* * *}$ \\
\hline Civil society group & -0.360 & $-0.552^{*}$ & $-2.769 * * *$ \\
\hline Business group & 0.162 & 0.176 & -0.732 \\
\hline Business group*RILE & $-0.061^{* *}$ & $-0.069 * *$ & -0.025 \\
\hline Recast & 0.235 & 0.331 & 0.809 \\
\hline Europeanisation & 0.052 & 0.076 & $-1.059^{* *}$ \\
\hline Regulatory policy & $1.087^{* * *}$ & $1.164^{* * *}$ & $1.951^{*}$ \\
\hline General regulation & -0.053 & 0.104 & $-1.688^{*}$ \\
\hline Public sector regulation & $0.766^{* * *}$ & $0.914^{* * *}$ & 0.646 \\
\hline Environment & $-1.312^{* * *}$ & $-1.640 * * *$ & $-3.061^{* * *}$ \\
\hline Banking & 0.318 & 0.340 & $-1.751^{*}$ \\
\hline IG position: opposed & & & -0.731 \\
\hline IG position: supportive & & & -0.079 \\
\hline Government position: opposed & & & -1.772 \\
\hline Government position: supportive & & & -0.293 \\
\hline IG opposed*government supportive & & & $1.955^{*}$ \\
\hline IG supportive* government opposed & & & $3.101^{*}$ \\
\hline Rights & & & 1.195 \\
\hline Evidence & & & -0.669 \\
\hline Costs and benefits & & & $1.092^{* *}$ \\
\hline National interests & & & 0.263 \\
\hline EU public interest & & & 0.484 \\
\hline National government: do something & & & $-1.553^{*}$ \\
\hline European Commission: do something & & & 0.061 \\
\hline Constant & $21.739 * * *$ & $27.971^{* * *}$ & $41.735^{* * *}$ \\
\hline \multicolumn{4}{|l|}{ EU and national consultations } \\
\hline GDP per capita (Log) & $-3.169 * * *$ & $-3.701^{* * *}$ & -2.684 \\
\hline Corporatism & -0.119 & -0.092 & $-0.472^{* *}$ \\
\hline RILE & $0.071^{* *}$ & $0.072^{* * *}$ & $-0.106^{*}$ \\
\hline Civil society group & -0.097 & -0.111 & -0.478 \\
\hline Business group & 0.415 & 0.400 & -0.131 \\
\hline Business group*RILE & 0.012 & 0.012 & 0.076 \\
\hline Recast & $1.261^{* * *}$ & $1.252^{* * *}$ & $2.652^{* * *}$ \\
\hline Europeanisation & $0.867^{* * *}$ & $0.878^{* * *}$ & 0.329 \\
\hline Regulatory policy & $2.224^{* * *}$ & $2.238^{* * *}$ & $1.873^{*}$ \\
\hline General regulation & $1.481^{* * *}$ & $1.482^{* * *}$ & -0.964 \\
\hline Public sector regulation & $1.719^{* * *}$ & $1.721^{* * *}$ & $2.110^{* * * *}$ \\
\hline Environment & -0.013 & -0.045 & -0.878 \\
\hline Banking & $1.971^{* * *}$ & $1.961^{* * *}$ & $1.475^{*}$ \\
\hline IG position: opposed & & & -0.408 \\
\hline IG position: supportive & & & -0.484 \\
\hline Government position: opposed & & & 0.838 \\
\hline Government position: supportive & & & 0.751 \\
\hline IG opposed*government supportive & & & 0.651 \\
\hline IG supportive* government opposed & & & -0.264 \\
\hline Rights & & & $1.506^{*}$ \\
\hline Evidence & & & -0.554 \\
\hline Costs and benefits & & & $1.187^{* * *}$ \\
\hline National interests & & & 0.170 \\
\hline EU public interest & & & $0.833^{*}$ \\
\hline National government: do something & & & -0.148 \\
\hline European Commission: do something & & & $0.813^{*}$ \\
\hline Constant & 0.470 & 2.298 & 2.292 \\
\hline
\end{tabular}


Table 2. (Continued).

\begin{tabular}{|c|c|c|c|}
\hline Variables & Model 1a & Model 1b & Model 2 \\
\hline \multicolumn{4}{|l|}{ No consultation } \\
\hline GDP per capita (Log) & $-9.926^{* * *}$ & $-9.707^{* * *}$ & $-7.860^{* * *}$ \\
\hline Corporatism & $0.234^{* * *}$ & $0.230^{* * *}$ & -0.095 \\
\hline RILE & $0.067^{* * *}$ & $0.065^{* * *}$ & $-0.202^{* * *}$ \\
\hline Civil society group & 0.012 & 0.050 & $-1.068^{*}$ \\
\hline Business group & -0.263 & $-0.318^{*}$ & $-1.317^{* * *}$ \\
\hline Business group*RILE & -0.024 & -0.015 & -0.043 \\
\hline Recast & 0.089 & 0.029 & -0.623 \\
\hline Europeanisation & -0.026 & -0.019 & -0.351 \\
\hline Regulatory policy & 0.178 & 0.165 & $2.838^{* *}$ \\
\hline General regulation & 0.275 & 0.218 & $1.745^{*}$ \\
\hline Public sector regulation & 0.127 & 0.048 & $1.159^{*}$ \\
\hline Environment & $-0.535^{* * *}$ & $-0.474^{* * *}$ & -0.036 \\
\hline Banking & 0.155 & 0.142 & 0.675 \\
\hline IG position: opposed & & & 0.265 \\
\hline IG position: supportive & & & -0.584 \\
\hline Government position: opposed & & & -0.041 \\
\hline Government position: supportive & & & 0.715 \\
\hline IG opposed* government supportive & & & -0.584 \\
\hline IG supportive* government opposed & & & -12.567 \\
\hline Rights & & & -0.194 \\
\hline Evidence & & & -0.445 \\
\hline Costs and benefits & & & 0.328 \\
\hline National interests & & & $-2.509^{* *}$ \\
\hline EU public interest & & & 0.326 \\
\hline National government: do something & & & 0.188 \\
\hline European Commission: do something & & & $-1.607^{* *}$ \\
\hline Constant & $33.875^{* * *}$ & $33.130 * * *$ & $23.390 * *$ \\
\hline$N$ & 2899 & 2596 & 596 \\
\hline LL & -2746.666 & -2638.981 & -521.698 \\
\hline chi2 & 1338.776 & 753.223 & 508.381 \\
\hline$P$ & 0.000 & 0.000 & 0.000 \\
\hline Mc Fadden R2 & 0.196 & 0.125 & 0.328 \\
\hline Mc Fadden adj. R2 & 0.184 & 0.111 & 0.223 \\
\hline $\mathrm{BIC}$ & 5828.161 & 5608.154 & 1561.006 \\
\hline AIC & 5577.330 & 5361.961 & 1205.396 \\
\hline
\end{tabular}

${ }^{*} p<0.05 ;{ }^{* *} p<0.01 ;{ }^{* * *} p<0.001$. Reference category: participation in national consultations.

actors' position papers are publicly available, providing us with the bulk of the document population. The set-up and frequency of national consultations differs across countries: German ministries and the German parliament consult actors by means of an invitation using a closed list; the same goes for British departments and the House of Commons. In contrast, Swedish and Dutch state institutions use an open list and invite all citizens to be involved through public calls. The Dutch government organised about twice as many consultations on the 20 directive proposals than the German government.

After collecting all 2961 policy documents we found on the 20 policy proposals, we sampled them for the subsequent document analysis in three steps: first, we developed an activity index for each actor. The more often the actor appeared in different venues, the higher his or her index value. Secondly, we made sure that our sample corresponded to the proportion of actor types (see above) 
that were vocal on each proposal in each country and at EU level. Thirdly, we coded a minimum of $30 \%$ of the documents tabled in each directive debate. The smaller the number of documents found in a debate, the larger was the proportion of coded documents. In sum, we coded 1010 policy documents for the actors at the EU level, in Germany, the Netherlands, Sweden, and the United Kingdom. This sample amounts to $34.1 \%$ of our full population of 2961 documents. Slovenian actors are not included in the document analysis due to different research emphases of the national teams in INTEREURO.

Then, we performed a computer-assisted qualitative content analysis to study the policy documents. These were written in four different languages (German, English, Swedish, and Dutch), which rules out a meaningful quantitative content analysis. To identify the actors' positions and arguments, six coders coded the policy documents according to a comprehensive code book implemented in MAXQDA. The code book included the names, definitions and short characterisations of the codes as well as a list of keywords. Each policy document formed a separate unit of analysis whose coding units ranged from one sentence at a minimum to one paragraph as a maximum. The coders marked the text passages (coding units) that indicate the positions and arguments of actors. Their training included test-test procedures such that different coders applied the same coding instructions independently to the same coding units for different policy proposals, languages, and document types (Krippendorff 2004: 215). Reliability was measured by Krippendorff's alpha (0.739) with a percentage agreement of 87.4. After completion of the coding procedure, the MAXQDA files were integrated and transformed into a quantitative dataset in which categorical variables indicate the positions taken by the actors $(-1=$ opposed, $0=$ neutral/ambiguous, $1=$ supportive) and dummy variables indicate if an argument has been made in a policy document or not.

According to the document analysis, $24.1 \%(N=182)$ of the interest organisations opposed the Commission proposals, $31.8 \%(N=240)$ were neutral or ambiguous, and $44.0 \%(N=332)$ voiced their support. National governments were more supportive: only $9.2 \%(N=273)$ of the actors were vocal on proposals on which governments voiced clear-cut opposition, $22.9 \%(N=680)$ were active on proposals on which governments held a neutral position, and $67.9 \%(\mathrm{~N}=$ 2016) are linked to supportive government positions. The correlation among interest groups' and governments' positions is significant, but small: Pearson's $\mathrm{r}=0.164(P=0.000 ; N=705)$ points to only weak overall positional alignments.

The usage of the studied arguments varies in our sample: $42.4 \%$ of the policy documents include cost-benefit calculations (320 of 754 actors), $40.5 \%$ of them present expert evidence (305 of 754), 23.5\% reference European public interests (177 of 754), $17.1 \%$ refer to national interests (129 of 754), and according to $9.8 \%$ the Commission proposal is about the (re-)allocation of rights (73 of 746). Usage also varies across actor types. Around half of the business interest associations (51\%) and firms (48\%) as well as a large portion of professional 
groups (44\%) invoke cost-benefit arguments. Business (28\%) and professional associations (27\%) also present scientific evidence to substantiate their positions more often than other actors (except research institutes - 41\%). By comparison, civil society groups refer mostly to European public interests (31\%), national interests (25\%), and cost-benefit aspects (22\%).

Among these arguments, only the rights-based claims (Pearson's $r=0.178$, $P=0.000 ; N=746$ ) and the tabling of expert evidence (Pearson's $r=0.119$, $P=0.001 ; N=754)$ are significantly - and positively - associated with the actors' positions. This is different with respect to the governments' positions: rights-based arguments (Pearson's $r=-0.163, P=0.000 ; N=596$ ), national interests (Pearson's $r=-0.231, P=0.000 ; N=603$ ), and European public interests (Pearson's $r=-0.262, P=0.000 ; N=603$ ) meet with greater government opposition, whereas cost-benefit arguments are associated with slightly greater government support for EU policies (Pearson's $\mathrm{r}=0.141, P=0.001 ; N=603$ ).

We measure the ideological positions of national governments by the RightLeft scale (RILE) which can reach values from -100 to +100 . As it is formed by subtracting left-wing positions from right-wing positions on the covered items, negative values indicate more left-wing positions and positive values indicate more conservative positions (Volkens et al. 2011). We weighted the RILE index according to the parties' vote shares in the national elections to capture the national parliamentary majorities' - and therewith government parties' - ideological positions. Ranging only from -9.89 to 7.91 with a mean of 0.775 , it indicates a preponderance of centrist governments. Within this range, conservative governments were more inclined to oppose incoming EU legislation than leftist governments. The correlation among the weighted RILE index and governments' positions amounts to Pearson's $r=-0.421(P=0.000$; $N=2965)$.

\section{Empirical analysis}

As a result of the sampling procedure and list-wise exclusion of missing observations, the number of observations reduces from 2899 to 596 national groups when bringing into the analysis positions, alignments, and arguments. ${ }^{3}$ We test our propositions in multinomial logit regressions. The dependent variable has four categories. It indicates the participation in national consultations $(N$ $=1395)$, EU-level consultations $(N=307)$, and in national and EU-level consultations $(N=277)$. It also includes those groups for which we could not find evidence of any participation in official consultations, but that were named in the media, by interviewees, or placed policy statements on their web pages $(N=920)$. As the default strategy of national groups, participation in national consultations forms the reference category.

The regression coefficients indicate the logged odds to exit to the EU level, to take part in consultations at both levels, and not to participate in consultations, 


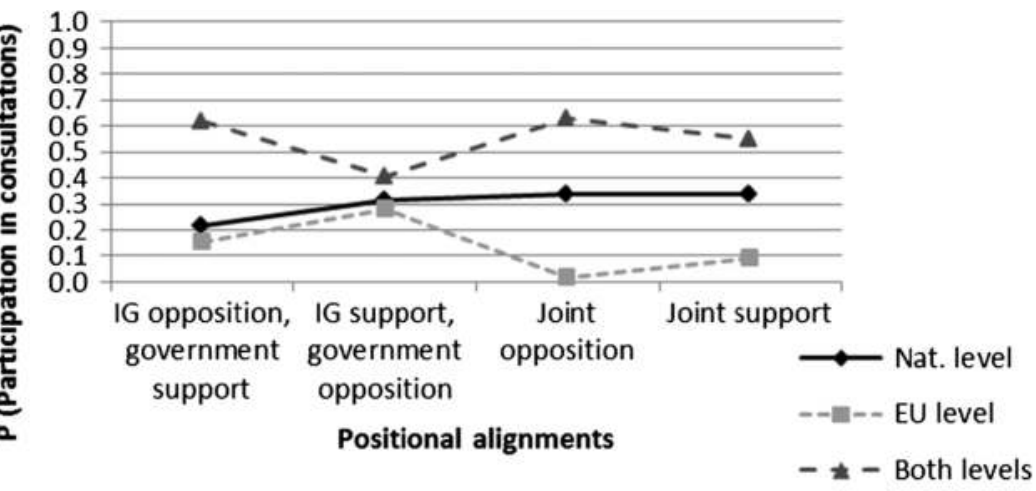

(b)

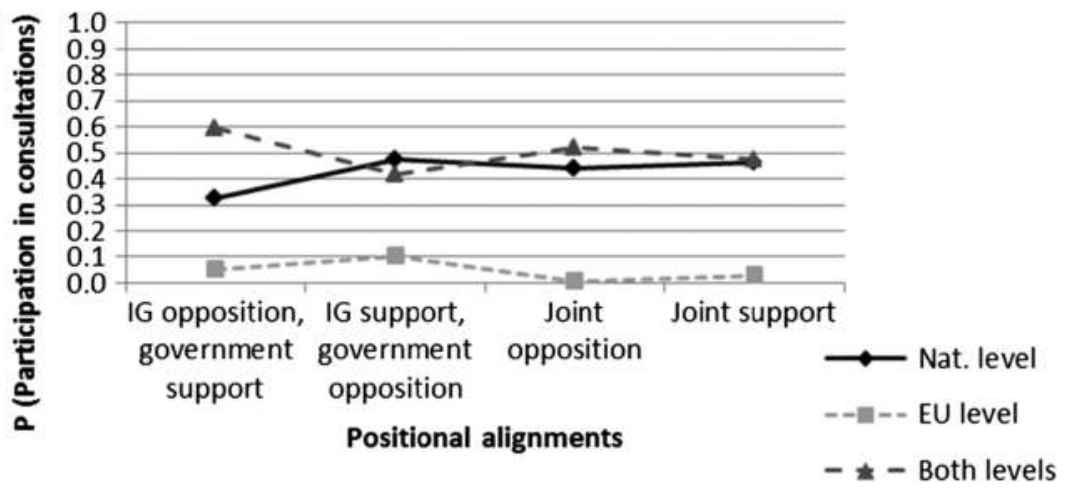

Figure 1. Predicted margins of participating in consultations conditional upon positional alignments.

Note: Based on Model 2, margins were calculated for business interest groups in Figure 1a (civil society groups in Figure 1b) active in regulatory policy and business regulation of banking, finance, and domestic commerce on a non-recast proposal. The groups present evidence and cost-benefit arguments and face a government with the mean RILE value. For civil society groups, the interaction among business and RILE is set to 0 , for business interests it amounts to the mean RILE value. Groups attribute policy responsibility to the Commission. For corporatism, wealth, and the Europeanisation of policy areas, average effects are included.

compared to participation in national-level consultations. In Table 2, we present two models. The first model includes the organisational, national, and policy controls as well as the RILE index (model 1). Model 1a presents this information including Slovenian groups and Model $1 \mathrm{~b}$ shows it excluding them because they are also missing in Model 2. Coefficients in Model 1a and Model 1b vary only slightly, indicating the robustness of results. Model 2 adds the arguments, positions, and alignments of Swedish, German, Dutch, and British groups to the control variables and the RILE index. Based on the chi ${ }^{2}$-tests, we reject the null hypothesis that none of the explanatory variables is associated with the outcomes.

Our interpretation concentrates on Model 2, which demonstrates that alignments and arguments impact on the choice of venues. We single out those four modes of positional alignments that are central to our argument: joint support, 
joint opposition, government support vs. group opposition, and government opposition vs. group support. To facilitate the interpretation of findings, we visualise the effects of the corresponding four combinations of logit coefficients. Figure 1 displays the predicted marginal probabilities to take part in national consultations only, in EU-level consultations only, and in consultations at both $\mathrm{EU}$ and national levels (multilevel consultations), holding constant common values of the other variables included in Model 2. Figure 1a presents them for business interests and Figure $1 \mathrm{~b}$ for civil society groups.

Figure 1 illustrates that it is common for domestic interest organisations to present their positions on EU policies in national consultations and not unusual for them to be present in EU-level consultations. In fact, many domestic groups pursue a two-level strategy in EU financial market regulation. We expected that interest groups concentrate their lobbying efforts on like-minded politicians and bureaucrats in the EU multilevel system. This is only partly true. The main effects of the interest groups' positions on the Commission proposals are insignificant - as are the coefficients for the governments' positions. Support for a Commission proposal does not per se lead a group to participate more frequently in EU-level consultations, which contradicts Hypothesis 1. Nor does a government's position alone matter. A group's positional alignment with the national government is more important to its venue choices. A national group holding the same position as the national government is more likely to participate in national consultations than a group holding the opposite position, which conforms to our general expectation. Domestic conflict with the national government increases the propensity to engage in EU-level consultations (see also Marshall and Bernhagen 2017), as the significant coefficients for the two terms measuring the interaction among interest groups' and governments' positions indicate (Model 2): a group is more inclined to move to the EU level if 'its' government supports the proposal and the group opposes it. The tendency to exit to the EU level (Hypothesis 2) is even higher if a group supports the Commission proposal and the government is opposed to it. ${ }^{4}$ In sum, it is not just the presence of domestic conflict that matters but also the direction of the positional alignment and the availability of a receptive venue at EU level. More generally, positional alignments lead to systematic variations of major interest representation routines.

Many domestic interest groups indicate their opposition to Commission proposals to policy-makers. This finding may seem trivial at first glance. However, it contradicts not only the presumption that interest groups concentrate their efforts strongly on like-minded actors but also findings of a major study on interest representation in the United States according to which 'supporters of the status quo often choose to do nothing when advocates challenge their interests; they conclude that the odds are in their favour that nothing will happen' (Baumgartner et al. 2014: 204). Unlike in the US, actors in the EU who oppose a policy initiative do not expect policy stability but policy change when the 
Commission prepares a policy proposal. Strong domestic mobilisation sets in to prevent the EU bill from turning into law or to amend it (Figure 1) if groups find themselves in unison with government. Groups feel slightly less need to take part in national consultations when the incoming EU proposal finds their support and has also 'their' government's backing, enabling them to let the national government act to some degree as their spokesperson.

Ideological alignments with the parliamentary majority parties also matter. According to Model 2, not only business interest associations but all domestic interest organisations that are facing a leftist government are more likely to exit to the EU level than when facing a conservative government (Hypothesis 3). This implies that fewer interest organisations will be present in domestic consultations. As leftist governments were generally more supportive of the incoming EU policies than domestic interests (see above), these may feel greater need to state critical positions directly at EU level. Note also that the significance and the direction of the coefficients for the ideological alignment vary systematically between Model 1 and Model 2. This suggests that positional alignments and argumentation patterns include more precise information on issue-specific allegiances between groups and governments than the governing parties' ideologies.

Now we scrutinise the impact of arguments on the usage of venues. We expected that national interest groups will present expert evidence to national and EU institutions (Hypothesis $4 \mathrm{a}$ ) and do not find a significant difference in the usage of expert information in different venues. The costs and benefits of EU policies are stressed by EU players and multilevel players rather than national players, which supports Hypothesis $4 \mathrm{~b}$. Recall that business interests rely heavily on cost-benefit arguments. Faced with the prospective costs of EU regulation, they present their concerns at both the national and EU level. Some even exit to the EU level because the national governments in this study tended to support policies on which cost-benefit arguments were exchanged.

Actors claiming rights tend to participate in consultations at both levels rather than merely in national consultations, which is consistent with Hypothesis 4c. They find it necessary to act at both levels because the re-allocation of rights causes frictions in the domestic contexts. Especially those actors that do not oppose the incoming EU directive point out their support in EU-level consultations in addition to their presence in national consultations as governments were rather opposed to EU policies re-allocating rights (see above). Likewise, organisations pointing to European public interests tend to do so at both levels, which conforms to Hypothesis 4e. In addition to voicing their support for the Commission proposal at EU level, they find it necessary to convince their rather sceptical national governments (see above).

Contrary to our expectations (Hypothesis $4 \mathrm{~d}$ ), the usage of arguments referencing national interests does not vary across different venues. As national governments tend to face Commission proposals with scepticism when perceiving 
that national interests are at stake (see above), supportive interest groups have an incentive also to put their version of the national interest forward to the European Commission. Note that actors who do not participate in consultations refer only rarely to national interests, suggesting that these are an important reason to mobilise. In sum, our findings indicate that arguments are associated with venue choices. Actors raise arguments in EU-level consultations in addition to rather than instead of their presentation at the national level. This is particularly noticeable when costs and benefits, rights, and Europe-wide public interests are at stake. The results corroborate that actors do not just address like-minded political institutions in EU legislation but tend to engage in twolevel politics to sway policy-makers with contrary opinions.

What are the major findings regarding our control variables? Group types matter less than anticipated, perhaps because the hurdles that must be overcome to take part in EU and national policy consultations are small. We find that business and civil society groups are more likely to participate (rather than not) in national consultations than other group types. Civil society groups tend to exit less to EU-level consultations than other group types (Models 1b, 2). They are more firmly tied to domestic contexts, relying on the mobilisation of national publics and lacking resources to state their positions in EU-level consultations. Figure 1 illustrates that, in conjunction with the effects of the other variables included in Model 2, business interests are more likely to act as multilevel players and adapt more flexibly to domestic alignments than civil society groups.

National contexts matter. It is more common for groups from wealthier member states: to participate in domestic consultations (rather than not); not to exit to EU-level consultations (Model 2); and not to take part in consultations at both levels. This is surprising because greater economic wealth is usually associated with a greater ability to act in the EU multilevel system (e.g. Carroll and Rasmussen 2017). But in Sweden and the Netherlands, our two wealthiest countries, domestic groups rely heavily on participation in national consultations. Moreover, groups from the pluralistic UK are more likely to become multilevel players than groups from the corporatist member states. Pluralism provides a context in which interest groups have a greater tendency to engage in venue shopping. Organisations not included in corporatist concertation display a tendency to exit to the EU level (Model 1b).

Policy contexts also play a role: Domestic groups are more likely to exit to the EU level or become multilevel players when facing EU regulatory policies. In response to policies that have (re-)distributive effects across member states they rely to a greater extent on domestic consultations. Furthermore, unexpectedly, public sector policies trigger greater participation in policy consultations at both levels than business regulation. Previous mobilisation experiences are also important. Directives that explicitly replace earlier EU laws are positively associated with the participation in consultations at both levels. Moreover, in 
more Europeanised policy areas, groups tend to be more active at both the $\mathrm{EU}$ and national levels only when not taking into account alignments and arguments. When doing so it becomes less likely that they will exit to the EU level. Note also that these policy categorisations do not suffice to account for all policy variations: groups active in environmental policy-making are less likely to exit to the EU level, and organisations vocal on banking, finance, and domestic commerce policy are more likely to become multilevel players than those in other policy areas. Finally, the perception of who should be responsible for dealing with the policy problem at hand is important. Groups indicating that the national government should do something are less likely to exit to the EU level, whereas groups that see the Commission in charge tend to become vocal at both levels.

\section{Concluding remarks}

The analysis of political access and venue shopping in EU policy-making has neglected the role of positions, alignments, and arguments. To help fill this gap, we included positional and ideological alignments among state institutions and interest groups as well as the policy arguments in a comprehensive empirical analysis. The findings indicate that these factors help account for the variability of domestic interest groups' strategies and call for a more systematic inclusion of alignments, arguments, and positions in future interest group studies. They also caution against the one-to-one adoption of theoretical propositions that are rooted in the empirical study of interest representation in other contexts.

We provide evidence delimiting the scope of general predictions of interest group strategies in previous theoretical and empirical work suggesting that interest groups will 'shoot where the ducks are' - meaning that they need 'to get themselves to Brussels' where EU decision-making power resides (Richardson 2006: 232) - approach mostly like-minded actors (Hall and Deardorff 2006), or do not engage in lobbying activities if they support the policy status quo (Baumgartner et al.2014). Focusing on the selection of venues at different levels, we contend that interest representation in the EU multilevel system follows task contingencies and organisational routines. First of all, national interest groups present their arguments and positions to the national government. Only then do they participate in EU-level consultations as an alternative or additional venue. Moreover, they tend to address those political institutions they consider to be in charge of solving the policy problem and find it easier to act in the EU multilevel system if they had prior mobilisation experiences. Secondly, interest groups in favour of the status quo and opposed to a Commission proposal do not settle back. Expecting policy change rather than policy stability in the EU multilevel system, they tend to mobilise even more than those who support the directive proposal. The fact that 19 of the 20 directive proposals we studied resulted in EU legislation ${ }^{5}$ illustrates that domestic interest groups do not 
usually have the capacity to block Commission proposals but may manage to have amendments made to them. Thirdly, national interest groups show some inclination to address like-minded actors, notably their national governments, but this does not preclude them approaching policy-makers with contrary opinions.

Finally, our study indicates that domestic interests have developed specific strategies to cope with positional alignments. We identified four participation patterns (see Figure 1) that constitute variations of their interest representation routines. Joint opposition of national governments and domestic groups leads to joint domestic mobilisation against the Commission proposal. Joint support results in groups relying more on the national government as spokesperson for their interests. Interest group opposition coupled with government support for a Commission proposal causes groups to engage in a two-level opposition, whereas interest group support in conjunction with government opposition causes them to exit to the EU level. The strategic flexibility of groups is contingent, inter alia, on group types, national contexts, and policy contexts. While business interests adapt their strategies noticeably in response to variations in their alignments with political institutions, the adaption of civil society interests is less pronounced because they are more firmly tied to domestic contexts.

\section{Notes}

1. We leave out inter-organisational linkages between parties and interest groups as the third major variety of alignments because we have not assembled data on such linkages. We also assume that interest groups which have organisational ties to political parties will be ideologically proximate to them.

2. The papers are: The Guardian, Daily Telegraph (United Kingdom), Süddeutsche Zeitung, Frankfurter Allgemeine Zeitung (Germany), deVolkskrant, NRC Handelsblad (The Netherlands), Dagens Nyheter, Svenska Davbladet (Sweden), Delo, Dnevnik (Slovenia).

3. The descriptive statistics for the 2899 observations included in model 1 are presented in Appendix Table A1.

4. All marginal effects for participation in national consultations and in multilevel consultations displayed in Figures $1 \mathrm{a}$ and $1 \mathrm{~b}$ are significant at $p=0.05$. For business interests, participation in EU-level consultations is significant at $p=$ 0.05 if they are opposed to the proposal and government supports it, and at $p=0.53$ if the group supports the proposal and government is opposed. The remaining marginal effects clearly miss conventional statistical significance levels. However, the significance of marginal effects hinges upon the combination of the values of all variables included in Model 2. We agree with Greene (2009: 487) that the inference should be about the estimated coefficients (i.e. the main effects and interaction terms for the positions in Model 2) rather than 'about a function of all the coefficients'

5. The Commission's proposal for a revision of national investor compensation schemes (COM [2010] 371) met resistance by the member states because of its financial and redistributive implications. It was withdrawn in 2015. 


\section{Acknowledgements}

We would like to thank the contributors to this special issue for their helpful comments. Moreover, we are grateful for the insightful suggestions of two anonymous reviewers.

\section{Disclosure statement}

No potential conflict of interest was reported by the authors.

\section{Funding}

Our research was co-financed by the Deutsche Forschungsgemeinschaft [grant number EI 461/6-1] and the Slovenian Research Agency Research Programme Political Science Research and project N5-0014 INTEREURO, as well as by the European Science Foundation project 10-ECRP-008: Comparative Research on Interest Group Politics in Europe (INTEREURO). An early version of this article was presented at a workshop on Multi-level Interest Representation in the European Union at the Ruhr-University Bochum, 28-29 April 2016 held in preparation for this special issue and funded by the Fritz-Thyssen-Foundation. 


\section{References}

Ball, William J. (1995). 'A Pragmatic Framework for the Evaluation of Policy Arguments', Policy Studies Review, 14:1-2, 3-24.

Bartolini, Stefano (2005). Restructuring Europe: Centre Formation, System Building, and Political Structuring between the Nation-State and the European Union. Oxford: Oxford University Press.

Baumgartner, Frank R., and Bryan D. Jones (1993). Agendas and Instability in American Politics. Chicago, IL: University of Chicago Press.

Baumgartner, Frank R., Jeffrey M. Berry, Marie Hojnacki, David C. Kimball, and Beth L. Leech (2014). "Money, Priorities, and Stalemate: How Lobbying Affects Public Policy', Election Law Journal, 13:1, 194-208.

Beyers, Jan, and Bart Kerremans (2012). "Domestic Embeddedness and the Dynamics of Multilevel Venue Shopping in Four EU Member States', Governance. an International Journal of Policy, Administration, and Institutions, 25:2, 263-290.

Beyers, Jan, Laura Chaqués Bonafont, Andreas Dür, Rainer Eising, Danica Fink-Hafner, David Lowery, Christine Mahoney, William Maloney, and Daniel Naurin (2014). 'The INTEREURO Project: Logic and Structure', Interest Groups and Advocacy, 3:2, 126-140.

Beyers, Jan, Iskander De Bruycker, and Inger Baller (2015). 'The Alignment of Parties and Interest Groups in EU Legislative Politics. A Tale of Two Different Worlds?', Journal of European Public Policy, 22:4, 534-551.

Binderkrantz, Anne, Peter Christiansen, and Helene Pedersen (2014). 'A Privileged Position? The Influence of Business Interests in Government Consultations', Journal of Public Administration Research and Theory, 24, 879-896.

Börzel, Tanja (2006). 'Europäisierung der Deutschen Politik?', in Manfred G. Schmidt and Reimut Zohlnhöfer (eds.), Regieren in der Bundesrepublik Deutschland Innenund Außenpolitik seit 1949. Wiesbaden: VS Verlag für Sozialwissenschaften, 491-511.

Bouwen, Pieter (2002). 'Corporate Lobbying in the European Union: The Logic of Access', Journal of European Public Policy, 9:3, 365-390.

Bunea, Adriana (2017). 'Designing Stakeholder Consultations: Reinforcing or Alleviating Bias in the European Union System of Governance?', European Journal of Political Research, 56:1, 46-69.

Bunea, Adriana, and Frank Baumgartner (2014). 'The State of the Discipline: Authorship, Research Designs, and Citation Patterns in Studies of EU Interest Groups and Lobbying', Journal of European Public Policy, 21:10, 1412-1434.

Carroll, Brendan and Anne Rasmussen (2017). 'Cultural Capital and the Density of Organized Interests Lobbying the European Parliament', West European Politics, doi: 10.1080/01402382.2017.1303243. 
Chalmers, Adam (2013). 'Trading Information for Access: Informational Lobbying Strategies and Interest Group Access to the European Union', Journal of European Public Policy, 20:1, 39-58.

Dür, Andreas, and Gemma Mateo (2016). Insiders versus Outsiders. Interest Group Politics in Multilevel Europe. Oxford: Oxford University Press.

Eising, Rainer (2004). 'Multi-Level Governance and Business Interests in the European Union', Governance. an International Journal of Policy, Administration, and Institutions, $17: 2,211-245$.

Eising, Rainer (2016). 'Studying Interest Groups: Methodological Challenges and Tools', European Political Science, 1-15, doi: 10.1057/eps.2016.14, (accessed 24 November 2016).

Eising, Rainer (2017). 'Imperfect Public Goods and the Logic of Selective Exit in EU Interest Organizations', West European Politics, doi: 10.1080/01402382.2017.1320173.

Eising, Rainer, Daniel Rasch, and Patrycja Rozbicka (2015). 'Institutions, Policies, and Arguments: Context and Strategy in EU Policy Framing', Journal of European Public Policy, 22:4, 516-533.

European Commission (1985). White Paper on the Completion of the Internal Market, 14th June 1985, available at http://europa.eu/documents/comm/white_papers/pdf/ com1985_0310_f_en.pdf (accessed 22 August 2016).

Gerring, John (2001). Social Science Methodology: A Criterial Framework. Cambridge: Cambridge University Press.

Greene, William (2009). 'Discrete Choice Modeling', in Terence C. Mills and Kerry Patterson(eds.), Palgrave Handbook of Econometrics. Volume 2: Applied Econometrics, London: Palgrave, 473-556.

Haas, Peter M. (1992). 'Epistemic Communities and International Policy Coordination', International Organization, 46:01, 1-35.

Hall, Richard L., and Alan V. Deardorff (2006). 'Lobbying as Legislative Subsidy', American Political Science Review, 100:01, 69-84.

Haverland, Marcus, Bernard Steunenberg, and Frans Van Waarden (2011). 'Sectors at Different Speeds: Analysing Transposition Deficits in the European Union', Journal of Common Market Studies, 49:2, 265-291.

Hojnacki, Marie, and David C. Kimball (1998). 'Organized Interests and the Decision of Whom to Lobby in Congress', American Political Science Review, 92:04, 775-790.

Hooghe, Liesbet, and Gary Marks (2001). Multi-Level Governance and European Integration. New York, NY: Rowman \& Littlefield Publishers.

Kitschelt, Herbert and Steven I. Wilkinson (2007). 'Citizen-Politician Linkages: An Introduction', in Herbert Kitschelt and Steven I. Wilkinson (eds.), Patrons, Clients, and Policies. Patterns of Democratic Accountability and Political Competition. Cambridge: Cambridge University Press, 1-49.

Klüver, Heike (2013). 'Lobbying as a Collective Enterprise: Winners and Losers of Policy Formulation in the European Union', Journal of European Public Policy, 20:1, 59-76.

Kohler-Koch, Beate, Peter Kotzian, and Christine Quittkat (2017). 'The Multi-Level Interest Representation of National Business Associations', West European Politics, doi: 10.1080/01402382.2017.1303244.

Kriesi, Hanspeter, Anke Tresch, and Margit Jochum (2007). 'Going Public in the European Union. Action Repertoires of Western European Collective Political Actors', Comparative Political Studies, 40:1, 48-73.

Krippendorff, Klaus (2004). Content Analysis Reader. An Introduction to Its Methodology. Thousand Oaks. California: Sage Publications.

Lowi, Theodore J. (1972). 'Four Systems of Policy, Politics and Choice', Public Administration Review, 32, 298-310. 
Mahoney, Christine (2008). Brussels versus the Beltway: Advocacy in the United States and the European Union. Washington, D.C.: Georgetown University Press.

Majone, Giandomenico (1989). Evidence, Argument, and Persuasion in the Policy Process. New Haven, CT: Yale University Press.

Marshall, David, and Patrick Bernhagen (2017). 'Government-Business Relations in Multi-Level Systems: The Effect of Conflict Perception on Venue Choice', West European Politics, doi: 10.1080/01402382.2017.1303245.

Müller-Rommel, Ferdinand (1988). 'Interessengruppenvertretung im Deutschen Bundestag', in Uwe Thaysen, Roger H. Davidson and Robert G. Livingston (eds.), US-Kongreß und Deutscher Bundestag. Opladen: Westdeutscher Verlag, 300-323.

Olson, Mancur (1965). The Logic of Collective Action: Public Goods and the Theory of Groups. London/Cambridge: Harvard University Press.

Richardson, Jeremy (2006). 'Organized Interests in the European Union', in Knud Jørgensen, Mark Pollack and Ben J. Rosamond (eds.), The Sage Handbook of European Union Politics. London: Sage, 231-246.

Risse, Thomas, Maria Green Cowles, and James Caporaso (2001). 'Europeanization and Domestic Change: Introduction', in Thomas Risse, Maria Green Cowles, and James Caporaso (ed.), Transforming Europe. Europeanization and Domestic Change. Ithaca: Cornell University Press, 1-20.

Schmidt, Manfred G. (1996). 'When Parties Matter: A Review of the Possibilities and Limits of Partisan Influence on Public Policy', European Journal of Political Research, 30, 155-183.

Tatham, Michael (2017). 'Networkers, Fund Hunters, Intermediaries, or Policy Players? The Activities of Regions in Brussels', West European Politics, doi: 10.1080/01402382.2017.1303246.

Vatter, Adrian, and Julian Bernauer (2009). 'The Missing Dimension of Democracy. Institutional Patterns in 25 EU Member States between 1997 and 2006, European Union Politics, 10:3, 335-359.

Volkens, Andrea, Onawa Lacewell, Sven Regel, Henrike Schultze, and Annika Werner (2011). The Manifesto Data Collection. Manifesto Project (MRG/CMP/MARPOR. Berlin: Wissenschaftszentrum Berlin für Sozialforschung (WZB).

\section{Appendix}

Table A1. Descriptive statistics of policy and national contexts (2899 observations).

\begin{tabular}{lcccc}
\hline Variable & Mean & Std. & Min. & Max. \\
\hline Consultations & 0.980 & 0.897 & 0 & 3 \\
GDP/Capita(log) & 3.464 & 0.208 & 2.93 & 3.66 \\
Corporatism & 0.709 & 2.327 & -2.49 & 3.82 \\
RILE & 0.775 & 6.858 & -9.89 & 7.91 \\
Civil society group & 0.135 & 0.342 & 0 & 1 \\
Business group & 0.209 & 0.407 & 0 & 1 \\
RILE*Business group & 0.128 & 3.180 & -9.89 & 7.91 \\
Environment & 0.371 & 0.483 & 0 & 1 \\
Banking & 0.176 & 0.381 & 0 & 1 \\
Recast & 0.219 & 0.414 & 0 & 1 \\
Regulatory policy & 0.905 & 0.294 & 0 & 1 \\
General regulation & 0.302 & 0.459 & 0 & 1 \\
Public sector regulation & 0.107 & 0.309 & 0 & 1 \\
Europeanisation of policy area & 3.714 & 0.607 & 1.5 & 4 \\
\hline
\end{tabular}




\title{
Government-business relations in multilevel systems: the eflect of conflict perception on venue choice
}

David Marshall and Patrick Bernhagen

\begin{abstract}
In multilevel systems, organised interests, including business frms, can pursue their political goals at diferent levels. At the same time, national systems of interest representation provide important incentive structures for corporate political behaviour. In this context, corporate political strategy is guided by frms' perceptions of their relationship with policy-makers. If this relationship is under strain in one venue, frms shift their lobbying efort to alternative venues, subject to constraints refecting national institutional legacies. Using survey data on 56 large German and British frms, the article investigates empirically how perceptions of government-business relations and national systems of interest representation interact to shape the political behaviour of large frms in multilevel systems. The analysis shows that perceived confict with public authorities at the national level leads to increased business lobbying at the EU level. Furthermore, national types of interest representation shape relative business engagement at the EU level as well as the readiness of frms to shift venue.
\end{abstract}

In multilevel systems, organised interests, including firms, have opportunities to pursue their political goals at different levels of government. This allows them to focus their advocacy effort on institutional venues that they perceive as biased in their favour while avoiding those in which their political standing is poor (Baumgartner and Jones 1991; Beyers and Kerremans 2012; Eising et al. 2017). At the same time, nation states continue to provide important incentive structures and normative and institutional contexts for corporate political behaviour. Traditionally, the link between national systems of interest representation and lobbying in the European Union (EU) has been conceptualised as the relationship 
between organised interests, typically business and labour, and national governments (Cowles 2001). The national institutional environment of business-government relations has been defined by the dichotomy of (neo)corporatism and pluralism (Schmitter 1974; Siaroff 1999). Firms embedded in corporatist systems have been found to rely on more encompassing groups to represent their interests in the EU and to be less likely to have the institutionalised capacity to lobby on their own (Grant 1993; Greenwood 2003: 23-4). While the EU's system of interest representation has been found to contain corporatist elements (Falkner 1998; Poletti et al. 2016), the literature overwhelmingly characterises the EU as more pluralist than corporatist (Coen 1997; Streeck and Schmitter 1991).

The EU's 'elite pluralism' (Coen 1997) has been found to make the EU system more congenial to the political aspirations of firms from pluralist than from corporatist backgrounds (Greenwood 2003: 23-4; Mazey and Richardson 1993: 199). However, more recent research on business lobbying in the EU questions the continued impact of national modes of interest representation. Analysing the role of corporatism in predicting direct corporate lobbying, Bernhagen and Mitchell (2009: 172) found that 'at the level of the EU such differences no longer matter where business interests are concerned. In this paper, we propose that the national institutional context continues to shape corporate political behaviour in the multilevel system of the EU, but in more complex ways than have hitherto been considered. To this end, we focus on an aspect of government-business relations that should matter to business lobbyists in any system of interest representation: their perception of how good or strained their relationship with policy-makers is. Thus, we investigate the extent to which perceptions of conflict between business actors and public authorities lead to venue shifts in lobbying activity. We want to find out whether perceived poor relations at the national level prompt firms to increase their lobbying activities at the supranational level and to what extent such strategic behaviour is affected by the national institutional context.

We pursue these questions empirically using survey data on 56 of the largest German and British companies spanning the principal sectors of the European economy. The political activities of large firms are of great empirical and normative significance (Hart 2004). Exercising substantial power over people as workers and consumers, firms are the leading institutions in capitalist society (Hart 2004). Combined with the fact that large firms are present in national and supranational European politics (Coen 1997, 1998) this makes them an important object of study. As Hart (2004: 48) points out, we cannot hope to understand their political role 'merely by studying peak associations or even trade associations, much less interest groups in general'. In the present article, we focus on firms' direct political activities, as opposed to collective action through business associations. Direct business lobbying is a political activity of high and increasing relevance and the object of an established research programme in its own right (Coen 1997, 1998; Hart 2004). 
Our two country cases - Germany and the UK - enable us to investigate variation in institutional environments, above all the domestic system of interest representation. The UK represents a pluralist system while Germany represents a moderately corporatist system of interest representation (Siaroff 1999). The two countries also provide substantively significant examples, representing the two largest EU economies that together comprise almost 40\%, respectively, of EU GDP (Eurostat 2016) and of the EU's 300 largest companies (Dullforce 2015). Our online survey allows us to measure variables that are notoriously difficult to observe - the political activity of firms and the beliefs and perceptions of in-house business lobbyists. Our analysis shows that perceived conflict between firms and public authorities at the national level leads to increased business lobbying at the EU level. However, the national context shapes relative business engagement at the EU level as well as the readiness of firms to shift venue.

In the next section, we explain theoretically how the quality of government-business relations shapes the lobbying strategies of firms in national and supranational contexts and how this relationship is in turn moderated by the national institutional context. Next, we outline our research design, data and analytical strategy. We then present our empirical findings before concluding by discussing the evidence in the light of the literature on business lobbying.

\section{Business lobbying, venue shopping and national systems of interest representation}

Lobbying is one of several types of political activity pursued by firms. Compared with collective action through trade associations, donations to political parties, or attempts to influence the opinion of the public and of other external actors through public campaigning or philanthropic and 'socially responsible' behaviour, direct lobbying is the most instrumental political activity for firms, and one which is rather narrowly targeted on specific benefits for the firm (Hansen and Mitchell 2000; Hillman and Hitt 1999). The literature on business lobbying is centred on a standard profit-maximising model that provides a simple, general and now familiar account of why firms lobby policy-makers: government decisions about how to use coercive powers and distribute resources have important consequences for a firm's revenues and costs (Grier et al. 1994; Stigler 1971). Some of these activities are less common in Europe than in the US, but direct business lobbying is present and growing in the EU and its member states. The EU institutions as well as national governments all legislate on the terms under which goods and services can be produced and traded in the EU, which, if considered a single unit, is the largest economy in the world. It is not surprising, then, to find that these important political venues attract considerable lobbying activity from firms (Rasmussen and Carroll 2014). 
Theories of multilevel governance suggest that firms from EU member countries interact with political institutions at both levels (Eising 2004; Kohler-Koch 1997; Marks and Hooghe 2001). In order to influence EU policy-making, these firms can lobby at the EU level or at the national level or both. Unlike firms from outside the EU, they can seek to enlist national governments to represent their interests in EU policy more effectively than firms from non-EU member countries do. Following the national route through the British government and the Council of Ministers has been identified as an important strategy for British businesses (Bennett 1999). Furthermore, some policy struggles of importance to business are fought out at both the national and the EU level. This is obvious in the case of EU directives, which need to be transposed into national law and offer opportunities for lobbying at the stage of transposition. Moreover, most EU regulations are implemented by national governments, so that lobbying at the implementation stage of EU policy can also take place at the national level. Therefore, as Coen (1998: 85) pointed out, 'firms play a complex multilevel game when seeking to influence the policy process. While these analyses concern lobbying after a policy decision is taken at the EU level, others point to multilevel venue shopping (Eising et al. 2017; Kohler-Koch 1997; KohlerKoch et al. 2017; Young and Wallace 2000). And finally, there is what Chari and Cavatorta (2002: 120) define as 'overlap issues' - i.e. 'issues where two separate, but related, domestic and supranational decisions must be taken because they fall within each level's jurisdiction. Thus, EU firms can lobby at multiple levels simultaneously, and large European firms frequently engage in multilevel lobbying games to influence the European policy process.

However, given budget and reputation constraints, rather than playing all relevant institutional fields at once, firms and other organised interests have incentives to deploy their political resources strategically (Eising 2004). This involves seeking out institutional venues they perceive as biased in their favour and avoiding those in which their political standing is poor. One strategy for dealing with such biases is to 'shop' for an alternative venue and attempt to move decision-making authority to a different policy arena. In the words of Baumgartner and Jones (1991: 1045), political actors 'try to alter the roster of participants who are involved in the issue by seeking out the most favourable venue for consideration of these issues'. If successful, a change in venue can lead to desired policy change (or, as the case may be, help to preserve a preferred status quo). According to Mazey and Richardson (2001: 220), political integration in Europe has created new opportunities for venue shopping by interest group actors in Europe. Indeed, they argued that venue shopping is part of the explanation for the (undisputed) growth in EC/EU level interest group formation and lobbying' (Mazey and Richardson 2001: 220). While Baumgartner and Jones developed the concept of venue shopping for the analysis of public policy-making in the US, Mazey and Richardson (2001) maintain that the EU's system of multiple access points makes venue shopping a useful concept for 
the analysis of lobbying in this polity. Others agree in principle but point out an important difference: in the multilevel system of the EU, where different institutions at different levels of government are involved in the policy process, venue shopping takes the form of concentrating the lobby effort on one of several possible levels without actually shifting decision-making to different venues (Beyers and Kerremans 2012). As Princen and Kerremans (2008: 1139) put it, '[i]nterest groups may choose between venues but the venues themselves are given'. Moreover, while the US literature has been dominated by analyses of horizontal shifts at one and the same level of government (see Holyoke et al. 2012 for an overview), the political system of the EU is more encouraging of vertical venue shifts between levels of government. The analysis that follows is concerned with the logic behind these vertical venue shifts.

For large firms, incentives to shift lobbying efforts to different venues can stem from changes in the political standing of firms within the political system. Firstly, for business as a whole, the public mood may be more sympathetic or less. For example, when citizens and policy-makers perceive the economy as doing well, they may be more willing to demand policies that are costly to business. This explains part of the 'fluctuating fortunes' of business over time (Vogel 1989). Secondly, different sectors are affected to different degrees by public decision-making (Grier et al. 1994), and at any given time some sectors enjoy better relations with policy-makers than others. And thirdly, individual firms may find their relationship with policy-makers more or less conducive to their political goals, where this relationship may be shaped by past interactions with policy-makers or the extent to which firms have been subject to individual administrative decisions, e.g. in the field of competition policy and merger control, commercial supervision, licensing, or procurement. As Holyoke (2003: 326) pointed out, '[b]ecause each venue contains a different set of government officials, the quality of the relationships between a group's lobbyist and these policymakers is likely to vary from venue to venue. Jointly, these factors determine the degree of attractiveness of a political market, which, according to Bonardi et al. (2005: 398), accounts for why a firm engages in political activities. Thus, firms have incentives to shift their political effort away from venues where government-business relations are conflictual to those venues where these relations are more harmonious.

Proposition 1: As national government-business relations deteriorate, firms increase their lobbying at the EU level relative to national-level lobbying.

However, it would be overly simplistic to expect firms headquartered in different countries to make strategic choices among multiple venues independently of the wider political context and the opportunities and constraints that this presents. Firms, like other political actors, are 'embedded' in social relations (Granovetter 1992). As a result, enduring differences can be observed between types of national capitalisms, which ensure that strategies in areas 
such as research and development, financing and internal corporate governance remain nationally distinct. With respect to these areas, Pauly and Reich (1997: 1) report that 'recent evidence shows little blurring or convergence at the cores of firms based in Germany, Japan, or the United States. We submit that these national differences extend to corporate political strategy too. Holding the political venue constant, implications of such embeddedness have been explored with respect to the political behaviour of affiliates of foreign corporations in Washington, DC (Rehbein 1995) and Brussels (Bernhagen and Mitchell 2009; Grant 1993). While Grant (1993: 171-2) found enduring differences between British and German firms, Rehbein (1995) reports strong similarities between the political strategies of foreign-owned and domestic firms. Similarly, Bernhagen and Mitchell (2009) found little support for the continued role of nationally distinct types of interest representation.

These contradictory and seemingly time-sensitive findings call for more careful theorising of the moderating role played by the institutional context. Political scientists have devoted years of research to identifying and classifying systems of interest representation and drawing out the political and economic consequences for these different systems and the actors operating within them (see Siaroff 1999 for a summary). The upshot from this conceptual work is widespread agreement that systems of interest representation possess multiple dimensions reflecting both interest group characteristics and policy process characteristics. In spite of ongoing debate about the precise conceptual boundaries and measurement of this aspect of political-economic integration, the theoretical rationale for these concepts is well established and its empirical applications have confirmed the robustness of the measurements used (Lijphart 1999; Siaroff 1999). Corporatist systems are characterised by relatively few, centralised and monopolistic interests with good access to the policy-making process and a disposition to compromise and bargain rather than maximise in the policy struggle. Typical examples include Austria, Sweden and Germany. Pluralist systems, by contrast, have numerous and competitive organised interests all struggling for access to policy-makers. Examples include the United States, United Kingdom and Australia. These differences have implications for direct corporate lobbying. More corporatist systems are characterised by a relatively low frequency of individual firm lobbying. Interests are centralised and monopolistic and the policy process is characterised by national bargaining between the government, representatives of business and representatives of labour.

This logic extends to other policy arenas. While the EU's system of interest representation has been found to contain corporatist elements (see Falkner 1998; Poletti et al. 2016), these lack the quasi-public functions assigned to major interest groups in a corporatist setting. The most important socioeconomic decisions are still made at the national level or are subject to national veto (Lijphart 1999: 44); and the European Economic and Social Committee has a 
purely advisory role. Accordingly, the EU is widely characterised as an 'élite pluralist arrangement between institutions and policy actors' (Coen 1997: 106, see also Cowles 1996; Streeck and Schmitter 1991). As a consequence, firms from pluralist systems that had developed the institutional capacity and experience to represent their own interests were argued to be well positioned for lobbying in the European policy arena: 'Anglo and American firms in particular, familiar with operating in pluralist environments, are used to operating outside groups ... whereas those used to the corporatist traditions of Germanic countries tend to place greater emphasis upon associations' (Greenwood 2003: 23-4). Similarly, Mazey and Richardson (1993: 199) found that, alongside American groups, British organisations were 'widely regarded as being among the most enthusiastic EC lobbyists'. By contrast, firms embedded in highly corporatist systems rely more heavily on encompassing groups to represent their interests in the EU and are less likely to develop the institutionalised capacity to lobby on their own. Thus, 20 years ago, Grant (1993: 15) noted that, in comparison to the US and the UK where firms have developed government relations offices, ' $\mathrm{g}$ ] overnment relations divisions are relatively unknown in Germany'.

However, the findings by Bernhagen and Mitchell (2009) suggest that firms from corporatist systems have caught up with the EU lobbying activity of their peers from pluralist systems. If this is an ongoing trend, another decade on we might now see firms from corporatist countries being even more inclined to lobby at the EU level than their peers from pluralist political economies. Moreover, it has been argued that corporatism makes EU-level interest representation more attractive to business in relative terms, because it empowers countervailing interests at the national level (Hix 2005: 265; see also Marks and McAdam 1996 for a similar argument). As corporatism gives organised labour a permanent seat at the bargaining table and easy access to policy-makers, it provides business interests with incentives to shift policy debates away from the national level. Both arguments imply that firms from countries with corporatist systems of interest representation now have greater incentives to lobby at the EU level.

Proposition 2: In the mature EU, firms headquartered in corporatist countries place a greater emphasis on EU-level lobbying relative to national-level lobbying than firms from pluralist countries.

While national systems of interest representation and the incentives they provide for businesses' political strategies have been changing, their basic structures endure. Moreover, a lasting effect has been that the late developers from corporatist countries have had to develop greater flexibility and a broader strategic action repertoire compared to their pluralist peers. The latter's institutional background had already equipped them rather well for lobbying in the context of the EU's elite pluralism (Coen 1997), thus demanding little ability to develop adaptation skills. These differences in the institutional context of German and British firms affect the way in which firms decide to switch venues when facing 
less than harmonious government-business relations at the national level of the home country.

However, the fact that large firms from pluralist systems are significant players in EU policy-making (Bernhagen and Mitchell 2009; Greenwood 2007; Mazey and Richardson 1993) suggests that there must be circumstances under which these firms shift lobbying activity to the EU level. As Princen and Kerremans (2008: 1137) point out, venue shopping is not a cost-free activity. Moreover, policy advocates may 'stick to national institutional venues because they lack strong institutional allies at the EU level' (Princen and Kerremans 2008: 1137). While for British firms the perception of conflict at the national level is not a sufficient condition to switch lobbying venues, they might do so in circumstances when a relatively supportive policy environment can be expected at the EU level (see also Eising et al. 2017). This rationale and its behavioural implications apply to firms from pluralist and corporatist systems alike. However, only for the former is it a necessary condition for changing venue.

Proposition 3: Firms from pluralist countries are less ready than firms from corporatist countries to abandon the national route in favour of EU lobbying when national government-business relations deteriorate.

By contrast, pull as well as push factors should play a similar role for firms from any system of interest representation. Ehrlich and Jones (2016) argue that firms located in countries where it is more costly for them to lobby are more likely to lobby at the EU level. These authors expect that 'the more receptive access points are, on average, to a particular interest, the cheaper lobbying will be for that interest and, thus, the more that interest should lobby' (2016: 473). We generalise this expectation and argue that firms decide to directly lobby the EU when doing so promises to be relatively more beneficial to them than lobbying at the national level. Thus, when taking into account how welcoming the target venue is expected to be by the firm considering a venue shift, we expect:

Proposition 4: Firms from any system of interest representation transfer their lobbying effort from the national to the EU level in response to increases in national conflict relative to that found at the EU level.

\section{Data and research strategy}

To evaluate these propositions empirically, we collected information on political activities of 56 large corporations headquartered in Germany and the UK in late 2015 and 2016. While the data we can use to evaluate our positions thus consist of cross-sectional measurements at a single point in time, a certain temporal order is implied in the theoretical argument presented above. While social scientists tend to think of causality in terms of changes in $X$ producing changes in Y, covariation between these two variables can also be the result of a 
process in which some third factor, perhaps in existence prior to both $\mathrm{X}$ and $\mathrm{Y}$, causes changes in the association between $X$ and $Y$ (Miller 1999: 121). Working with cross-sectional data, we evaluate our causal arguments with the aid of observable implications of a cross-sectional nature. To this end, we derive the following testable hypotheses about statistical associations in cross-sectional data from our four propositions above:

H1: The more conflictual government-business relations are at the national level, the more firms lobby at the EU level relative to the national level.

H2: Firms headquartered in Germany place a relatively greater emphasis on EU-level lobbying than firms headquartered in the UK.

H3: The effect of conflictual government-business relations at the national level on relative EU lobbying is greater for German firms than for British firms.

H4: For firms from both countries, there is a positive association between relative EU lobbying and national conflict relative to EU-level conflict.

The country selection enables us to assess the effects of corporatist and pluralist systems of interest representation. ${ }^{1}$ The sample was drawn in 2013 from Standard \& Poor's Capital IQ database, which, at the time of drawing the sample, contained about 70,000 publicly traded and more than 700,000 privately owned companies from all over the world. From this source, which served as our population frame, we sampled the 100 largest corporations, respectively, from each of the two countries. ${ }^{2}$ For this purpose, we have created a size ranking based on the average of rankings by revenues, profits, assets and employee numbers. ${ }^{3}$ To obtain data on the political activities of these firms in the context of domestic and European policy-making we have used an online survey of senior managers in the firms' corporate public affairs and public relations departments. Through a lengthy process of online searches and telephone enquiries, we obtained contact details, including email addresses, for 146 senior personnel. To maximise response rates, we then sent a hand-signed letter to the personal work address of each potential respondent. This was followed up with an email invitation containing a link to the survey and, in many cases, several reminders by email and telephone. The questionnaire was in the field from 7 December 2015 until 18 May 2016. In the end, we received 56 complete or almost complete questionnaires, yielding a response rate of $38 \%$. The response rates in the two countries were quite similar, with our final sample of 56 split into 29 German and 27 British firms.

Through the survey we identified lobbying behaviour and are able to estimate variation across the two countries and for different levels of governance (national and EU). To determine firms' relative engagement across national and EU levels of governance, we asked: 'thinking generally about your company's engagement with policy-makers, approximately what percentage of your company's advocacy time is spent' at a number of venues including 'EU institutions' 
and 'at the national government of the country where your company is headquartered.' ${ }^{4}$ To measure relative EU lobbying we divided the percentage of lobbying time a firm devotes to EU lobbying by the sum of the percentages of national (HQ) and EU lobbying $\left(\frac{\% \text { EU lobbying }}{\% \text { National lobbying }+ \text { EU lobbying }}\right)$. This variable can range from 0 to 100 , where a value of ' 0 ' would indicate that a firm only engages in national lobbying (HQ). The distribution of this variable is shown in Figure 1.

Central to the assessment of our theoretical claims is the measurement of the perceived quality of the relationship between the firm and policy-makers at both the national and EU level. To gauge this we asked respondents, 'in general, how would you characterise the relationship between your company and public authorities at the national, regional (European Union) levels?' Five response categories were provided: very cooperative, moderately cooperative, neither cooperative nor conflictual, moderately conflictual and very conflictual, with 1 representing a very cooperative relationship and 5 a very conflictual one. The actual values range from 1 to 4 , with a mean of 2.3. In addition, as we are also interested in the relative quality of government-business relations across national and EU levels, we calculate a measure of 'relative conflict'. This was created by dividing the difference between the variable 'national conflict' and a corresponding measure of EU conflict by the total of the two measures: $\left(\frac{\text { National conflict-EU conflict }}{\text { National conflict }+E U \text { conflict }}\right)$. Here higher values indicate greater national conflict relative to that encountered at the EU level, with a value of zero (the actual mean) representing no difference in conflict across venues.



Figure 1. Distribution of the relative EU lobbying measure. 
When estimating the hypothesised associations, we need to take account of other factors that may shape firm lobbying at different levels of government and their ability to shift venues when circumstances recommend doing so. Large firms with a stake in the policy issue and of a size to attract the attention of regulators are generally more likely to lobby than smaller ones (Boies 1989; Grier et al. 1994). They will also be more likely to lobby at different levels of government and be better able to shift resources between venues if they need to. Thus, we take into account the possibility that lobbying behaviour varies according to company size, even within a sample of large companies. To measure firm size, we follow established practice in the literature by taking the natural $\log$ of revenues in million US dollars for the financial year 2015, using data from the Financial Times (Dullforce 2015).

Furthermore, as mentioned above, firms' incentives to become politically active in a particular venue differ by industrial sector. At the point of conducting the survey an extensive amount of post-crisis financial regulation had just been passed, with a considerable amount of regulatory detail left to finalise increasing the incentives for firms in the financial sector to engage in EU-level lobbying. Therefore, we control for industrial sector by incorporating an indicator for 'financial sector.' ${ }^{5}$ Finally, given that the majority of the largest German and British firms have significant international markets and that many operate large offshore facilities, differences in internationalisation may affect the ability of firms to vary their lobby efforts between venues. To obtain a measure of international political engagement we return to the aforementioned question on the time firms spend across lobbying venues. From the responses we construct a measure of 'foreign CPA (corporate political action)' - defined as the percentage of time spent lobbying 'national governments of other countries in which your company has facilities, markets and/or suppliers'. Empirically, this variable ranges from 0 to 75 and has a mean of $19 .{ }^{6}$ Table A1 in the Appendix lists summary statistics of all variables.

\section{Results}

We begin with descriptive overviews of the variables and associations of interest. First we consider the mode of interest representation through which firms express their positions to policy-makers. Of particular interest is whether companies now routinely take a direct approach, which would suggests a weakening of corporatist modes of encompassing interest group representation (Bernhagen and Mitchell 2009). Our survey data show that the overwhelming majority of firms within our sample (44 out of 54) reported that they directly approached policy-makers. ${ }^{7}$ Furthermore, all the firms in our sample stated that they had a government relations unit. As Figure 2 illustrates, German companies are as likely to approach policy-makers directly as they are to approach them via a trade association, which means they pursue a dual strategy of interest 


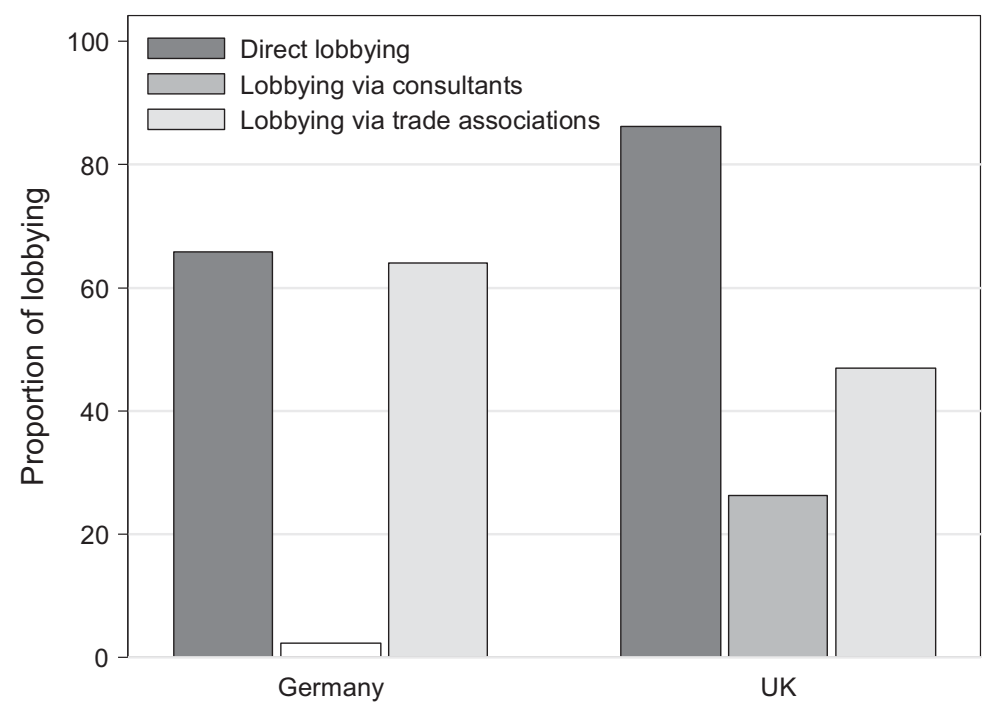

Figure 2. German and British firms' lobbying practice.

Note: The three within-country mean differences are statistically significant (t-test) at the 0.05 level; $n=54$.

representation. ${ }^{8}$ Nevertheless, there are differences in German and British lobbying practices: while UK firms also frequently use the associational route for them the direct approach is the dominant strategy. The use of consultants, finally, features in British firms' strategy, while it is virtually absent in the German part of the sample.

This picture remains largely intact when we compare the mode of interest representation by country and across policy types. For this, we coded responses across the 19 specific policy areas for which firms were asked to indicate their activity into either regulatory or non-regulatory policy. The patterns shown in Figure 3 indicate that there is only limited variation across policy types, with the exception of UK direct lobbying, which is more pronounced for regulatory policies than for non-regulatory policies.

The analysis shown in Figures 4 addresses the question of which level of governance large firms direct their lobbying activity towards. The distinction is between firms lobbying the policy-making institutions of their country of headquarters and of the EU (Bennett 1999; Bernhagen and Mitchell 2009; Grant 1993). The comparison suggests that, while the national arena is an important lobbying venue for firms from both countries, the propensity to target the national level rather than the European level is much more pronounced for British firms. While German firms are roughly equally active at the national (country of headquarters) and EU levels, British firms are more than twice as active at the national level than they are at the EU level. This lends initial support to Hypothesis 2. 




Figure 3. Lobbying across policy types.

Note: The only significant $(<0.05)$ difference is between regulatory and non-regulatory lobbying; $n=54$.

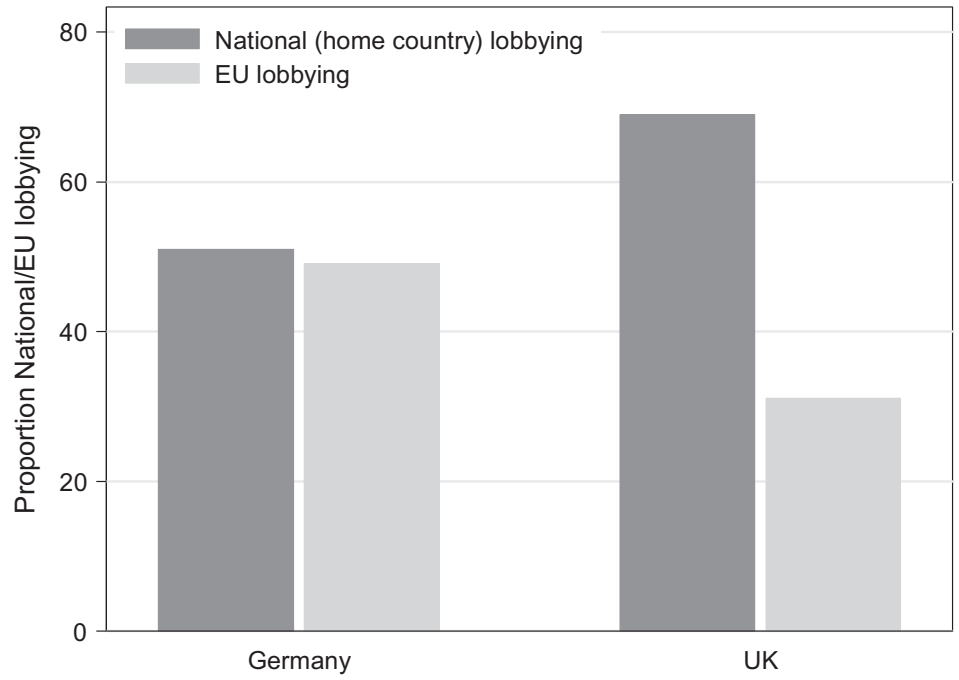

Figure 4. Comparing national \& EU lobbying.

Note: Difference in means between German and British firms are significant (t-test) at the 0.05 level; $n=56$.

The analysis so far has highlighted important differences between German and British corporate lobbying practices, as well as likely areas of convergence. However, when firms engage with policy-makers in order to achieve favourable outcomes, the quality of the government-business relationship is likely to be critical to achieving these goals. Therefore, as hypothesised (H1), when 
government-business relations are poor at the national level, the likelihood of firms shifting lobbying attention to the EU level will increase. Figure 5 shows mean levels of respondents' perceived conflict with policy-makers at the national and EU level, respectively. Higher values indicate greater levels of conflict and lower levels correspond to a more cooperative relationship. According to our data, there is no significant difference between British and German firms, whose mean levels of conflict perception range from 2.1 to 2.3 for both levels of government, with identical median scores of 2 . While average perceptions indicate moderately cooperative to neutral relationships, there is considerable variation among firms (see Table A1 in the Appendix) and only a weak correlation between national and EU levels of conflict (-0.175).

To address our hypotheses directly, we estimate three multivariate regression models with bootstrapped standard errors, and firms' relative EU lobbying (compared to the national level) as the dependent variable (see Table 1). All models include variables controlling for firm size (revenue (log)), financial sector and foreign CPA. The expectation from Hypothesis 1 is that the more conflictual government-business relations are at the national level, the more firms lobby at the EU level relative to the national level. This expectation finds support in Model 1, where the coefficient for national conflict is positive and statistically significant. A one-unit increase in the five-point scale of national conflict is associated with an increase in EU lobbying of 8.3 percentage points relative to all lobbying at the EU and national (HQ) levels, which is an effect of considerable magnitude.

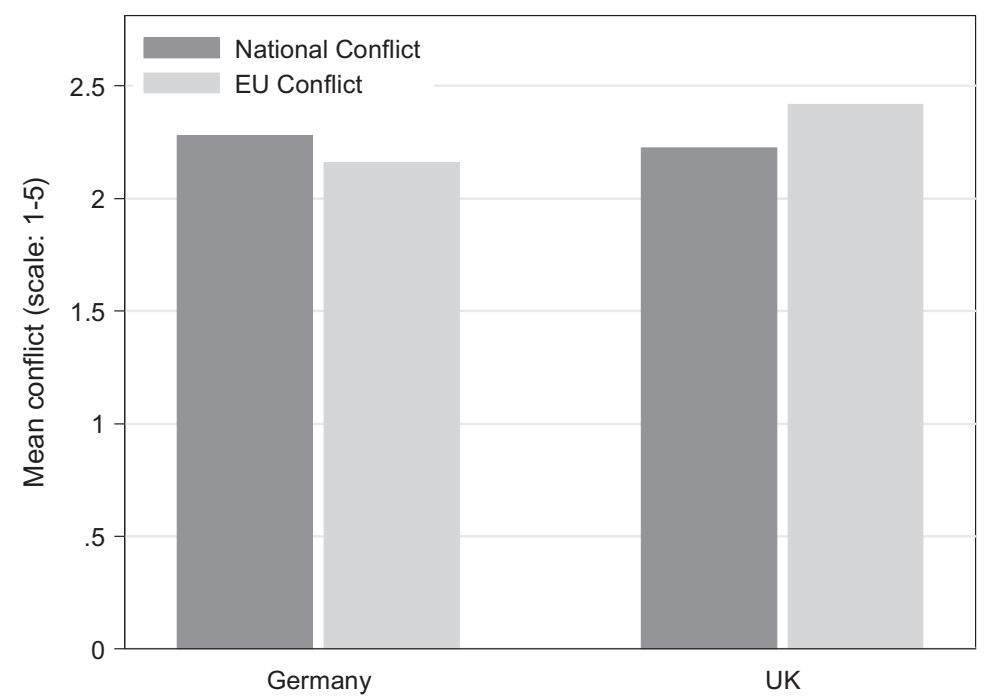

Figure 5. Comparing mean levels of conflict.

Note: Difference in means between German and British firms are not significant; $n=56$. 
Table 1. Multivariate regression models of EU lobbying relative to national lobbying.

\begin{tabular}{lccc}
\hline & Model 1 & Model 2 & Model 3 \\
\hline National conflict & $8.296^{* * *}$ & $15.715^{* * *}$ & $(4.54)$ \\
Relative conflict & $(3.09)$ & & $(11.33)$ \\
& & & $-18.655^{* * *}$ \\
Country (UK) & & 9.683 & $(5.85)$ \\
& $-21.453^{* * *}$ & $(15.75)$ & 4.609 \\
Revenue (log) & $(6.51)$ & $5.207^{*}$ & $(2.92)$ \\
& 3.815 & $(2.73)$ & 0.322 \\
Financial sector & $(3.18)$ & 3.198 & $(10.42)$ \\
& 7.090 & $(7.93)$ & 0.304 \\
Foreign CPA & $(8.73)$ & $0.555^{* *}$ & $(0.28)$ \\
& $0.544^{* *}$ & $(0.22)$ & \\
NatConflict*UK & $(0.24)$ & $-14.210^{* * *}$ & $(6.06)$ \\
& & & $(23.02)$ \\
RelativeConflict*UK & & & 4.669 \\
& & -42.360 & $(30.75)$ \\
constant & -12.476 & $(31.15)$ & 0.51 \\
R-square & $(30.96)$ & 0.47 & 44 \\
$n$
\end{tabular}

Note: Bootstrapped standard errors in parentheses.

${ }^{*} p<0.1 ;{ }^{* *} p<0.05 ;{ }^{* * *} p<0.01$

The expectation from Hypothesis 2 is that German firms place relatively greater emphasis on EU lobbying than British firms. In addition to the bivariate analysis presented in Figure 4, the country coefficient in Model 1 is statistically significant and in the expected direction, providing further support for Hypothesis 2. According to the estimate for Model 1, the proportion of time spent on EU lobbying relative to national-level lobbying is 21.5 percentage points lower for UK firms than for German firms. Of the control variables, the coefficient for foreign CPA is significant and in a positive direction. The more a firm lobbies across borders the more freely it engages at the supranational level.

In Model 2 we analyse the interaction between national conflict and country $(\mathrm{UK}=1$, Germany $=0)$ in order to test whether the effect of conflictual government-business relations at the national level on relative EU lobbying is greater for German firms than for British firms (H3). The coefficient for the interaction term is negative and statistically significant. To aid interpretation, Figure 6 shows how the effect of national conflict on relative EU lobbying is conditional on the national context, with bars representing the $95 \%$ confidence intervals. As the perceived level of national conflict with policy-makers increases, German firms shift their lobbying effort from the national to the EU level, whereas we do not find such association for British firms. At the lower levels of domestic conflict, the ratio of EU to national lobbying is similar for firms from both countries.

To estimate whether there is a positive association between relative EU lobbying and national conflict relative to EU-level conflict (H4), in Model 3 


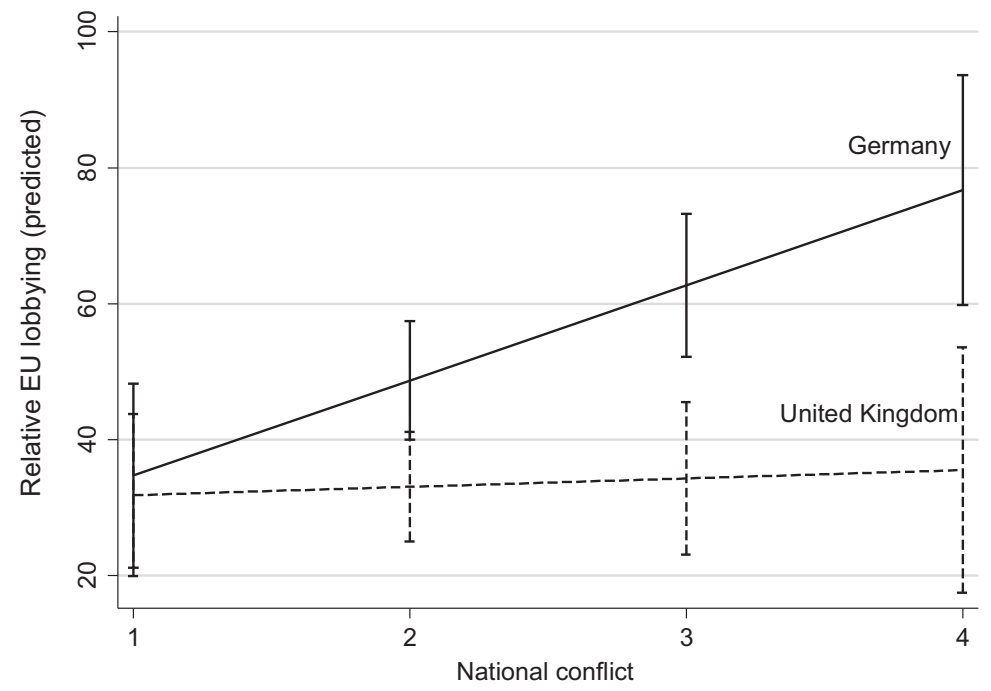

Figure 6. Interaction of national conflict and country of headquarters.

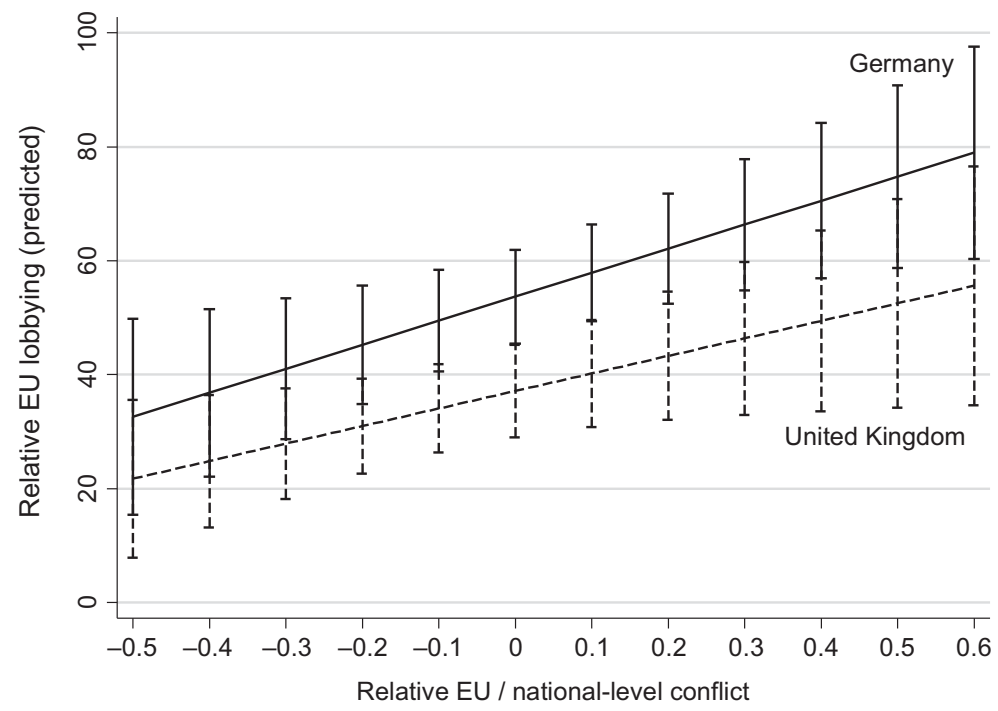

Figure 7. Interaction of relative conflict and country of headquarters.

we interact relative conflict and country. The interaction effect is not statistically significant, indicating that there is no slope difference between the two countries. This supports Hypothesis 4. To facilitate interpretation, we illustrate this effect in Figure 7. Taken together, the estimates for the two interactions in Models 2 and 3 support the argument behind Hypotheses 3 and 4. While 
German firms shift venues in response to conflict, this is not a sufficient condition for British firms, which require greater certainty that shifting venues will lead to interactions with more sympathetic policy-makers (Proposition 4).

\section{Conclusion}

We have argued that firms adapt their lobby strategies to changes in their political environment by shifting activities away from a venue with conflictual government-business relations to alternative venues (Proposition 1). These shifts take place within nationally distinct contexts represented by corporatist and pluralist political economic systems. In the contemporary EU, these make business lobbying at the EU level more attractive for firms from corporatist countries than for their pluralist counterparts (Proposition 2). Our findings provide evidence for a process of change that has unfolded over the past quarter-century. While Grant (1993) and others found direct firm lobbying at the level of the EC/EU to be dominated by firms from the pluralist systems of interest representation of the AngloSaxon world, Bernhagen and Mitchell (2009) found that, by 2005, differences in lobby behaviour between firms from pluralist and corporatist backgrounds had disappeared. Another decade later, the original difference seems to be reversed: according to our 2015 survey data, British firms are more likely to lobby their national government while German firms are more likely to engage at the EU level.

Moreover, the ability of firms to shift venues as the need arises is taken up more readily by firms from a corporatist background, which over the past 30 years have accumulated experience in negotiating a multilevel political environment and adapted from corporatist to pluralist contexts (Proposition 3 ). This provides them with a strategic advantage over firms from the pluralist background of the UK, who did not expend great effort in adapting to the supranational policy arena of the EU, as both national pluralism and the EU's system of interest representation encourage direct firm lobbying. Finally, we argued that differences between firms from pluralist and corporatist backgrounds should disappear when the quality of government-business relations at the EU level is taken into account in addition to the level of national conflict, because the calculus of relative conflict is shared by firms from both systems (Proposition 3). Our statistical analysis of firm-level survey data supports this proposition. Thus, we can infer that perceived conflict between firms and public authorities at the national level leads to increased business lobbying at the EU level. Moreover, while national institutions and types of interest representation shape relative business engagement at the EU level as well as the readiness of firms to shift venue, firms from any background seek to abandon conflictual lobbying environments if alternative venues look more promising.

Our analysis contributes to the literatures on business lobbying and venue shopping in four principal ways: First, our findings support the claim by Bonardi et al. (2005) that the degree of attractiveness of a political market accounts for 
the extent to which a firm engages in political activities within that arena. By showing that firms from a pluralist background, unlike their corporatist peers, are willing to reduce political engagement in conflictual environments only when greener pastures are in sight, we add to this general argument that it is the relative attractiveness of political markets that matters for firms' strategic choices. Second, previous studies on venue shopping by companies restricted their explanatory factors to the country level (Ehrlich and Jones 2016) and the sector level (e.g. Bernhagen and Mitchell 2009), assuming that these affect all firms within a country, resp. sector, equally. By measuring incentives for venue-shifting at the level of the firm, we allow for the possibility that some firms within the same country and even sector may find policy-makers more receptive to their concerns than others. Thus, compared with the previous literature, in the present article we have gone one level deeper into the political circumstances surrounding individual firms. Third, while the analyses by Ehrlich and Jones (2016) and by Bernhagen and Mitchell (2009) were restricted to using data on EU-level lobbying by companies, our survey data enable us to measure the relative importance of EU- and national-level lobbying as reported by companies' public affairs managers. Fourth, by examining venue choices of European firms across levels of government, we contribute to the empirical literature on multilevel governance as well as the venue shopping literature. To the former (e.g. Eising 2004), we add the insights about the national-level constraints on the fluidity of political advocacy. Regarding the latter, we add new evidence on vertical venue shifts to a literature that has been dominated by analysis of horizontal shifts at one and the same level of government (see Holyoke et al. 2012).

Through our study's focus on the lobbying strategies of large firms in multilevel systems, we have provided insights into the political activity of what are often considered the most economically powerful non-state actors in capitalist democracies. These large internationally connected entities are the types of businesses that should have the ability to escape political context when they perceive the need to do so. Our analysis suggests that this ability is frequently put to use. However, firms' responses to deteriorating government-business relations in a particular venue are contingent on the domestic institutional context. German firms place a bigger emphasis on EU lobbying compared with British firms. They are more readily willing to shift venues than British firms when national government-business relations deteriorate. However, under the right circumstances - i.e. when EU-level government-business relations are perceived as being better than national-level relations - British firms are as ready to redeploy their lobby resources as their German peers. For the continued role of nationally distinct systems of interest representation, the sample of firms we analysed consists of least likely cases: Within their respective countries, these large firms are the least likely to be influenced by national legacies and patterns of interest representation. This provides us with confidence that the findings reported here would be replicated if a sample of more and smaller firms were used. 
Finally, while our country cases contain two EU member states, one of these is currently preparing to leave the EU. British business actors have, on average, been strong supporters of the UK's membership in the EU. We expect that these actors will intensify their lobbying at both the national and EU level, to contain the damage incurred from 'Brexit' and to help secure single market membership for the UK. Following the Brexit negotiations, EU lobbying by British firms should continue at an increased level. If the UK moved from EU membership to a status similar to membership of the European Economic Area, its business actors can be expected to behave more like Norwegian firms: they should intensify their lobbying activity in Brussels as they will no longer have a government patron at the table but will still be subject to the common market rules. If the UK exits without single market membership status, we should also see increases in British firms' lobbying activity in Brussels, analogous to US business lobbying there. Thus, after German firms have overtaken British firms in their readiness to shift lobby resources from the national to the EU level by the time the data for the present study have been collected, the future may see a reversal of this trend. Even at present, however, British firms are somewhat more active in lobbying at the foreign national level than are German firms. This reflects a stronger anchoring in foreign governance structures relative to EU governance, suggesting, in turn, that British firms' political strategy is relatively well suited for Brexit and its consequences.

\section{Notes}

1. Since our sample does not include firms from Northern Ireland, in the remainder of the article we simply refer to 'British firms'.

2. We initially sampled 100 companies from Germany and the UK, but increased the country- $n$ to 104 and 107 , respectively, to compensate for low response rates.

3. Following established practice in the literature, size is measured by revenues in US\$ million made during the financial year 2012. Profit is gross profit revenues in US\$ million realised during 2012. Assets are total current assets of the corporation in US\$ million in 2012, while the number of employees is the total number of employees of a corporation for that year.

4. Other venues prompted are 'national governments of other countries in which your company has facilities, markets and/or suppliers', 'regional institutions (e.g. the European Union or NAFTA)', 'international / global institutions (e.g. WTO, UN, UNCCC)', and 'international private standard-setting bodies (e.g. ISO or International Electrotechnical Commission)'.

5. Firms are coded as belonging to the 'financial sector' if their main activity falls within the SIC Code Division H ('Finance, insurance, \& real estate'). We have also estimated all models with a dummy variable indicating the manufacturing instead of the financial sector (together these two sectors comprise $56 \%$ of the sample). This does not affect the substantive results reported here (see Table A2 in the Appendix). Due to limited degrees of freedom, we present the theoretically more interesting findings controlling for financial sector.

6. British firms are somewhat more active in lobbying at foreign national level than German firms. This reflects a stronger anchoring in foreign governance structures relative to EU governance. 
7. Respondents were asked, '[i]n the policy areas that you selected above, in which of the following ways did you express your position to policy-makers?' Responses are non-exclusive and comprise 'approach policy-makers directly ourselves', 'enlist the services of external consultants', 'work through a trade association' and 'other'. For this question we received 54 responses.

8. Here and in Figure 2, a mean of 1 would indicate that all firms adopt a particular mode of lobbying, whereas a value of 0 would suggest that none of them do.

\section{Acknowledgements}

We would like to thank Beth Leech and the participants of the workshop held in preparation for this special issue at Ruhr University Bochum, 28-29 April 2016 for very helpful comments, and Vanessa Bausch, Felix Goldberg and Carola Majer for valuable research assistance.

\section{Disclosure statement}

No potential conflict of interest was reported by the authors.

\section{Funding}

The research for this paper is part of the Borderless Politics project (www.abdn.ac.uk/ research/borderlesspolitics/) and was supported by the Economic and Social Research Council [grant ID ES/I036974/1].

\section{References}

Baumgartner, Frank R., and Bryan D. Jones (1991). 'Agenda Dynamics and Policy Subsystems', Journal of Politics, 53:4, 1044-74.

Bennett, Robert J. (1999). 'Business Routes of Influence in Brussels: Exploring the Choice of Direct Representation', Political Studies, 47:2, 240-57.

Bernhagen, Patrick, and Neil J. Mitchell (2009). 'The Determinants of Direct Corporate Lobbying in the European Union', European Union Politics, 10:2, 155-76. 
Beyers, Jan, and Bart Kerremans (2012). 'Domestic Embeddedness and the Dynamics of Multilevel Venue Shopping in Four EU Member States', Governance, 25:2, 263-90.

Boies, John L. (1989). 'Money, Business, and the State: Material Interests, Fortune 500 Corporations, and the Size of Political Action Committees', American Sociological Review, 54:5, 821-33.

Bonardi, Jean P., Amy J. Hillman, and Gerald D. Keim (2005). 'The Attractiveness of Political Markets: Implications for Firm Strategy', Academy of Management Review, 30:2, 397-413.

Chari, Raj S., and Francesco Cavatorta (2002). 'Economic Actors' Political Activity in "Overlap Issues": Privatisation and EU State Aid Control', West European Politics, 25:4, 119-42.

Coen, David (1997). 'The Evolution of the Large Firm as a Political Actor in the European Union', Journal of European Public Policy, 4:1, 91-108.

Coen, David (1998). 'European Business Interest and the Nation State: Large Firm Lobbying in the European Union and Member States', Journal of Public Policy, 18:1, 75-100.

Cowles, Marie Green (1996). 'The EU Committee of Am Cham: The Powerful Voice of American Firms in Brussels', Journal European Public Policy, 3:3, 339-58.

Cowles, Maria Green (2001). 'The Transatlantic Business Dialogue and Domestic Business-Government Relations', in Maria Green Cowles, James A. Caporaso and Thomas Risse (eds.), Transforming Europe: Europeanization and Domestic Change. Ithaca, NY: Cornell University Press, 159-79.

Dullforce, Anne-Britt (2015). 'FT 500 2015, Europe 500', Financial Times, available at http://www.ft.com/cms/s/2/a352a706-16a0-11e5-b07f-00144feabdc0.html\#axzz46ew HEMQE (accessed 15 March 2016).

Ehrlich, Sean D., and Eryn Jones (2016). 'Whom Do European Corporations Lobby? The Domestic Institutional Determinants of Interest Group Activity in the European Union', Business \& Politics, 18:4, 467-88.

Eising, Rainer (2004). 'Multilevel Governance and Business Interests in the European Union', Governance, 17:2, 211-45.

Eising, Rainer, Daniel Rasch, Patrycja Rozbicka, Danica Fink-Hafner, Mitja Hafner-Fink, and Meta Novak (2017). 'Who Says What to Whom? Alignments and Arguments in EU Policy Making', West European Politics, doi: 10.1080/01402382.2017.1320175.

Eurostat (2016). Gross Domestic Product at Market Prices, available at http://ec.europa. eu/eurostat/tgm/refresh (accessed 20 March 2016).

Falkner, Gerda (1998). EU Social Policy in the 1990s: Towards a Corporatist Policy Community. London: Routledge: European Public Policy Series.

Granovetter, Mark (1992). 'Economic Institutions as Social Constructions: A Framework for Analysis', Acta Sociologica, 35:1, 3-11.

Grant, Wyn (1993). Business and Politics in Britain, 2nd ed. London: Macmillan.

Greenwood, Justin (2003). Interest Representation in the European Union, 2nd ed. London: Palgrave Macmillan.

Greenwood, Justin (2007). 'Organized Civil Society and Democratic Legitimacy in the European Union', British Journal of Political Science, 37:2, 333-57.

Grier, Kevin B., Michael C. Munger, and Brian E. Roberts (1994). 'The Determinants of Industry Political Activity, 1978-1986', American Political Science Review, 88:4, 911-26.

Hansen, Wendy L., and Neil J. Mitchell (2000). 'Disaggregating and Explaining Corporate Political Activity: Domestic and Foreign Corporations in National Politics', American Political Science Review, 94:4, 891-903. 
Hart, David (2004). “'Business” is Not an Interest Group: On the Study of Companies in American National Politics', Annual Review of Political Science, 7, 47-69.

Hillman, Amy J., and Michael A. Hitt (1999). 'Corporate Political Strategy Formulation: A Model of Approach, Participation, and Strategy Decisions', The Academy of Management Review, 24:4, 825-42.

Hix, Simon (2005). The Political System of the European Union, 2nd ed. Basingstoke: Palgrave.

Holyoke, Thomas T. (2003). 'Choosing Battlegrounds: Interest Group Lobbying across 40 Multiple Venues', Political Research Quarterly, 56:September, 325-36.

Holyoke, Thomas T., Heath Brown, and Jeffrey R. Henig (2012). 'Shopping in the Political Arena: Strategic State and Local Venue Shopping by Advocates', State and Local Government Review, 44:April, 9-20.

Kohler-Koch, Beate (1997). 'Organized Interests in the EC and the European Parliament', European Integration Online Papers (EIoP), 1, 9, available at https://ssrn.com/ abstract $=302669$

Kohler-Koch, Beate, Peter Kotzian, and Christine Quittkat (2017). 'The Multi-Level Interest Representation of National Business Associations', West European Politics, doi: 10.1080/01402382.2017.1303244.

Lijphart, Arend (1999). Patterns of Democracy. Government Forms and Performance in Thirty-Six Countries. New Haven, CT: Yale University Press.

Marks, Gary, and Liesbet Hooghe (2001). Multi-Level Governance and European Integration. Lanham, MD: Rowman and Littlefield.

Marks, Gary, and Doug McAdam (1996). 'Social Movements and the Changing Structure of Political Opportunity in the European Union', West European Politics, 19:2, 249-78.

Mazey, Sonia, and Jeremy Richardson (1993). 'Interest Group Behaviour in the European Community: A European Lobbying Style?', in Jeremy Richardson (ed.), Pressure Groups. Oxford: Oxford University Press, 191-213.

Mazey, Sonia, and Jeremy Richardson (2001). 'Interest Groups and EU Policy-Making: Organisational Logic and Venue Shopping', in Jeremy Richardson (ed.), European Union: Power and Policy-Making. London: Routledge, 217-37.

Miller, Warren E. (1999). 'Temporal Order and Causal Inference', Political Analysis, $8: 2,119-46$.

Pauly, Louis W., and Simon Reich (1997). 'National Structures and Multinational Corporate Behavior: Enduring Differences in the Age of Globalization', International Organization, 51:Winter, 1-30.

Poletti, Arlo, Dirk De Bièvre, and Marcel Hanegraaff (2016). 'WTO Judicial Politics and EU Trade Policy: Business Associations as Vessels of Special Interest?', British Journal of Politics \& International Relations, 18:1, 196-215.

Princen, Sebastiaan, and Bart Kerremans (2008). 'Opportunity Structures in the EU Multi-Level System', West European Politics, 31:6, 1129-46.

Rasmussen, Anne, and Brendan J. Carroll (2014). 'Determinants of Upper-Class Dominance in the Heavenly Chorus: Lessons from European Union Online Consultations', British Journal of Political Science, 44:2, 445-59.

Rehbein, Kathleen (1995). "'Foreign-Owned Firms" Campaign Contributions in the United States: An Exploratory Study', Policy Studies Journal, 23:1, 41-61.

Schmitter, Philippe C. (1974). 'Still the Century of Corporatism?', Review of Politics, $36: 1,85-131$.

Siaroff, Alan (1999). 'Corporatism in 24 Industrial Democracies: Meaning and Measurement', Journal of European Research, 36:2, 175-205.

Stigler, George (1971). 'The Theory of Economic Regulation', Bell Journal of Economics and Management Science, 2:1, 3-21. 
Streeck, Wolfgang, and Philippe C. Schmitter (1991). 'From National Corporatism to Transnational Pluralism: Organizing Interests in the Single European Market', Politics and Society, 19:2, 133-64.

Vogel, David (1989). Fluctuating Fortunes: The Political Power of Business in America. New York, NY: Basic Books.

Young, Alasdair, and Helen Wallace (2000). Regulatory Politics in the Enlarging European Union. Manchester: Manchester University Press.

\section{Appendix}

Table A1. Summary statistics.

\begin{tabular}{lccccc}
\hline Variable & $N$ & Mean & Std. Dev. & Min. & Max. \\
\hline Relative EU lobbying & 48 & 41.7 & 25.2 & 0 & 90 \\
Relative national lobbying & 50 & 59.9 & 26.1 & 10 & 100 \\
National conflict & 56 & 2.25 & 1 & 1 & 4 \\
EU conflict & 56 & 2.3 & 0.9 & 1 & 4 \\
Relative conflict & 51 & 0 & 0.3 & -0.6 & 0.6 \\
Revenue (natural log) & 56 & 9.4 & 1.1 & 6.2 & 11.5 \\
Financial sector & 56 & 0.15 & 0.36 & 0 & 1 \\
Foreign CPA & 51 & 19 & 14.5 & 0 & 75 \\
Direct lobbying & 54 & 0.79 & 0.42 & 0 & 1 \\
Lobbying via consultant & 54 & 0.15 & 0.35 & 0 & 1 \\
Lobbying via trade association & 54 & 0.59 & 0.51 & 0 & 1 \\
\hline
\end{tabular}

Table A2. Multivariate regression models of EU lobbying relative to national lobbying, with financial sector replaced by manufacturing sector.

\begin{tabular}{lccc}
\hline & Model 1 & Model 2 & Model 3 \\
\hline National conflict & $7.694^{* *}$ & $14.959^{* * *}$ & \\
& $(-3.85)$ & $(-3.76)$ & $47.627^{* * *}$ \\
Relative conflict & & & $(-12.27)$ \\
Country (UK) & $-17.903^{* * *}$ & 12.131 & $-15.876^{* * *}$ \\
& $(-6.79)$ & $(-13.61)$ & $(-5.82)$ \\
Revenue (log) & 2.039 & 3.886 & 3.572 \\
& $(-3.33)$ & $(-3.301)$ & $(-2.56)$ \\
Manufacturing sector & 10.886 & 9.767 & 9.506 \\
& $(-7.53)$ & $(-5.48)$ & $(-6.02)$ \\
Foreign CPA & $0.380^{*}$ & $0.431^{*}$ & 0.213 \\
& $(-0.23)$ & $(-0.33)$ & $(-0.23)$ \\
NatConflict*UK & & $-14.009^{* * *}$ & \\
& & $(-6.06)$ & -16.858 \\
RelativeConflict*UK & & & $(-19.62)$ \\
& & & 10.514 \\
Constant & 3.410 & -31.068 & $(-25.97)$ \\
& $(-32.1)$ & $(-31.15)$ & 0.5 \\
R-square & 0.4 & 0.47 & 44 \\
$n$ & 46 & 46 & \\
\hline
\end{tabular}

Note: Bootstrapped standard errors in parentheses.

${ }^{*} p<0.1 ;{ }^{* *} p<0.05 ;{ }^{* * *} p<0.01$. 


\title{
German MPs and interest groups in EU multilevel policy-making: the politics of information exchange
}

\author{
Arndt Wonka
}

\begin{abstract}
Policy-makers regularly interact with interest groups to exchange information. This provides, it is often argued, the former with input needed to formulate effective policies and the latter with political influence. This article shares this broad perspective. In contrast to large parts of the literature, however, the paper argues for a political perspective on information exchanges between parliamentarians and interest groups. This perspective builds on party politicians' ideological positions to explain the scope of parliamentarians' information exchanges with different types of interest groups. In order to move away from the idea that information is a scarce resource for parliamentarians their interactions with interest groups are put in the context of their intra-party information exchanges. The empirical analysis of original survey data of members of the German Bundestag broadly confirms the article's main arguments.
\end{abstract}

Political parties and interest groups are omnipresent interest representatives and intermediaries in European Union politics: National political parties provide linkages which national parliamentarians and members of the European Parliament strategically employ to advance their political causes (Finke and Dannwolf 2013; Proksch and Slapin 2010; Wonka and Rittberger 2014). National and European interest groups are also active in the EU's multilevel system to promote their members' interests and to influence EU policies accordingly (Beyers 2002; Dür and Mateo 2012; Eising 2004). Unsurprisingly, there is strong agreement in the literature that both political parties and interest groups are central actors in EU multilevel politics. Their political activities have a strong effect on the dynamics of EU politics as well as the content of EU policies. The activities of political parties and interest groups in EU policy-making, however, are hardly ever analysed in a way that allows for an assessment of their mutual relevance and the factors explaining the strength of their political ties. 
In this paper I focus on parliamentarians' information exchanges with different types of interest groups. Information is a crucial resource for parliamentarians (Lupia and McCubbins 2000) as it facilitates legislators' ability to assess the political importance of political matters and their work on legislation. Drawing on theories of interest group mobilisation and of legislative behaviour, I argue that information exchanges between interest groups and legislators are driven by legislators' partisan ideologies. More specifically, I will show that legislators primarily rely on politically like-minded interest groups to acquire political information (Hall and Deardorff 2006). Parliamentarians from left-leaning political parties rely strongly on the input from labour unions and non-governmental organizations (NGOs) which represent public interests, while legislators from rightist parties primarily interact with business associations. Before focusing on the interactions between parliamentarians from different political groups and different types of interest groups, I will put legislators' interactions with interest groups into the context of their partisan exchanges. Political parties have a broadly acknowledged role as information providers (Müller 2000). Taking this role into account allows us to move away from the idea that information is a scarce resource for politicians.

While proposing a general theoretical argument, this article empirically investigates information exchanges between national parliamentarians and interest groups on EU policies in a specific institutional and political context.

National parliaments play a subordinate role in EU multilevel policy-making. While not having a direct and binding say in the formulation and adoption of EU legislation at the EU level, they have various formal information rights as well as the right to scrutinise whether EU law corresponds to the subsidiarity principle. Moreover, all legislatures in EU member states have institutionally adapted to EU policy-making by establishing EU affairs committees. While these vary in their formal powers and the extent to which they can bind governments' EU actions (Winzen 2012), they provide national parliamentarians with means to follow and participate in EU policy-making (Auel and Benz 2005). Parliamentarians complement the use of these institutional means by their partisan contacts and channels in order to involve themselves in EU politics (Finke and Dannwolf 2013; Proksch and Slapin 2010; Wonka and Rittberger 2014).

The German Bundestag has, compared to parliaments in other member states, strong powers in EU politics (Winzen 2012). These provide German parliamentarians with strong incentives to engage in EU multilevel policy-making. Moreover, I argue that the importance of ideology varies between interactions among legislators and interest groups in EU and in national policy-making. In national policy-making, ideology has a greater impact on exchanges between party politicians and interest groups than in EU policy-making, because national issues still seem to be electorally more salient (Green-Pedersen 2012; Hoeglinger 2016). Members of Parliament (MPs) might, as a consequence, select more carefully the interest groups they consult on domestic issues. If 
these considerations are correct, the empirical results presented here provide a least likely test and a conservative empirical estimation of the role which political like-mindedness plays in legislators' information exchanges with interest groups. In addition, Germany has a proportional electoral system and a corporatist system of economic governance (Siaroff 1999: 184-5). Both factors encourage cooperative relationships among political parties and between parties and interest groups (Cusack et al. 2007; Lijphart 1999: 182-3) and further contribute to the least likely character of the empirical test conducted in this study.

The article is structured as follows. In the next section I will place the information contacts which members of the Bundestag maintain with interest groups in EU policy-making in the context of their intra-party information ties to politicians in EU and national institutions. In a second step I will develop the article's main argument on the political logic of parliamentarians' interactions with interest groups. According to this argument, parliamentarians use the information provided by interest groups with similar political interests as a 'legislative subsidy' (Hall and Deardorff 2006) that helps them to advance their agenda and policy initiatives. After a brief section on the research design and the data used in the empirical analysis, I will present and discuss the empirical results. The article ends with a brief conclusion.

\section{The political logic of MPs' information demands from interest groups}

Members of parliament are in need of information to fulfil their tasks as representatives and legislators (Krehbiel 1991; Lupia and McCubbins 2000; Müller 2000). To act as representatives and legislators they require information on their constituencies' needs and preferences as well as on the potential political, economic and regulatory effects of legislation. Interest groups play an important role in the provision of this information (Baumgartner et al. 2009: 54-7, 129-48; Burstein 2014: 130-59; Hall and Deardorff 2006; Hansen 1991; Milbrath 1963).

Previous studies of interest groups' EU-related activities show that these report regularly interacting with political parties in EU (Dür and Mateo 2013; Rasmussen 2012) and national policy-making (Rasmussen and Lindeboom 2013). These studies, however, tend to neglect the effects of political ideology and interests on the intensity of these exchanges. In a recent study Otjes and Rasmussen (2017) find that interest groups lobby those political parties which share their broad political ideology but that this effect is moderated by the frequent alternation of governments of the left and right. De Bruycker 2016: 558-9) shows that NGOs in EU policy-making report to be in closer contact with left-wing party groups in the European Parliament (EP), whereas business interest groups are not found to focus their lobbying activities on rightist parties in the EP. This paper complements these studies on the alignments 
between interest groups and parties but takes a different perspective. Instead of drawing on information provided by interest groups, it relies on the information exchanges which German parliamentarians report to have with interest groups. This perspective allows for a more direct analysis of the motives which guide parliamentarians' information exchanges with interest groups. It differs from Marshall's (2015) study that also relies on information provided by parliamentarians (of the European Parliament). While Marshall is interested in interest groups' motives to approach different parliamentarians the present study focuses on the parliamentarians' demand for information.

Figure 1 shows that members of the Bundestag regularly interact with interest groups to obtain their assessments of specific pieces of EU legislation. However, while interest groups are important information providers for legislators, they are by no means the only sources of information (Hall and Deardorff 2006: 71; Milbrath 1963: 181-2, 189-91). In addition to their personal staff and media, legislative committees and plenary discussions, parliamentarians can rely on their own party organisation and on other members of their party in political office to obtain information that aids their assessment of political developments and facilitates their policy work. In short, information is not necessarily a scarce resource for legislators (Jones and Baumgartner 2005: 9-10). Supporting the argument on the diversity of legislators' information sources and on the ubiquity of information, Figure 1 shows that while members of the Bundestag regularly contact interest groups to obtain information on specific EU policies, interest groups are only one among a number of sources and not necessarily the most important one (Figure 1).

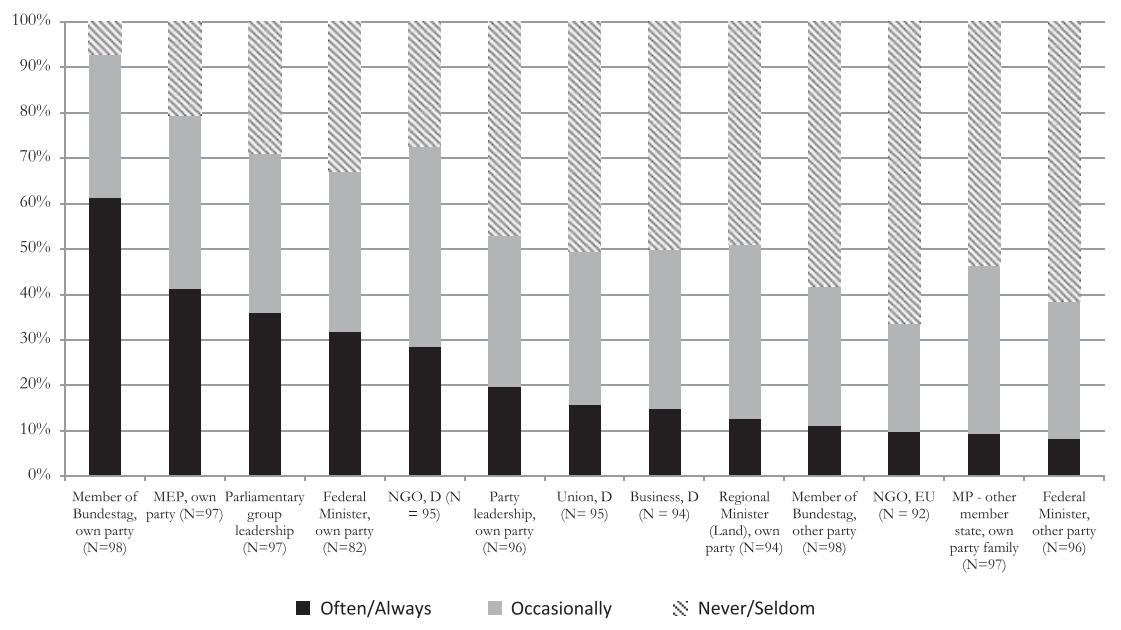

Figure 1. MPs' information contacts to party and interest group representatives.

Note: The data was obtained from an online survey with members of the German Bundestag. Parliamentarians were asked the following question:'Please indicate how often you contact the below listed [actors] to obtain information on planned or current policies at the EU level.' Only those actors are reported which were mentioned as being contacted 'often/always' or 'occasionally' by at least $30 \%$ of parliamentarians. 
The fact that interest groups are only one among a number of information sources for legislators is of theoretical relevance. It prevents us from overestimating interest groups' informational role and power over MPs resulting from it. If we conceptualise interactions between interest groups and politicians as information exchanges, the existence of a large number of potential information sources reduces bilateral information dependencies and thus the political power resulting from these exchanges of any one actor over another. In addition, the fact that information is not necessarily a scarce resource for legislators should also inform our theoretical reasoning in two related ways: on the motives which drive legislators' interactions with different types of interest groups and on the quality of the informational ties between legislators and interest groups resulting from these. It is these aspects to which I now turn.

Hall and Deardorff (2006) present two broad theoretical arguments which are centred on information and have been argued to drive interactions between legislators and interest groups. While both accounts accord information a key role in explaining interest groups' influence on legislators, they differ in the causal mechanisms they hypothesise to be at play as well as in their expectations on the types of legislators interest groups will target with their information. From a persuasion perspective, legislators interact with a heterogeneous set of (different types of) interest groups to learn more about their constituencies' interests and to adjust their own positions accordingly (Hall and Deardorff 2006: 71; Hansen 1991; Milbrath 1963). The authors, however, propose an alternative perspective of lobbying: interest groups provide information to legislators as a legislative subsidy. The subsidy perspective's implications deviate from those of the persuasion perspective. Legislators are expected to interact with those interest groups that share their interests and positions instead of exploring the positions of groups with heterogeneous positions (Hall and Deardorff 2006: 72-5).

In this article, I argue for a political perspective on information exchanges between legislators and interest groups. My argument broadly follows the subsidy argument. The definition of (EU) information employed here is broad. Information comprises both the technical and political aspects of a policy which are important for legislators' electoral (Hansen 1991: 12; Milbrath 1963: 183) and policy-seeking ambitions (Beyers 2004: 213-14; Burstein 2014: 133). Thus, the information provided by interest groups allows legislators to assess three things: the importance of issues in order to set political priorities, a policy's potential regulatory and economic effects and the relative support or opposition to a policy by electorally relevant political constituencies (Burstein 2014: 132-3). The information contacts reported below do not comprise interactions that aim at the formation of common positions or the coordination of political action. There is, however, a relatively strong correlation between information exchanges and exchanges through which members of the Bundestag coordinate 
political positions and strategies with interest groups. ${ }^{1}$ There is an analytical and a practical motivation to rely, like most survey research, on a generic concept of information: From the political support perspective laid out here, legislators will ask for any information that helps them to advance their political cause and the analytical distinction of the technical and political aspects of a policy seems less relevant. Moreover, it would have been impossible to collect data on parliamentarians' information relationships with a diverse set of actors for a number of different information dimensions without risking a further decrease in the survey response rate. The following item was used to collect data on legislators' information exchanges: 'Please indicate how often you contact the below listed [actors] to obtain information on planned or current policies at the EU level.'

As shown above (Figure 1), information is not necessarily a scarce resource for legislators. The availability of information from different sources - political parties, parliamentary debates, committee hearings, public advocacy by diverse interest groups, media, etc. (Burstein 2014: 98) - increases the likelihood that parliamentarians are knowledgeable about the positions different political actors and diverse constituencies hold on particular policies. Uncertainty about their constituencies' political preferences (Hansen 1991: 12, 16-17) should therefore not be legislators' foremost concern when interacting with interest groups. I argue instead that legislators' interactions with interest groups are primarily driven by their ambitions to pursue specific policy goals. They use these interactions to obtain information from politically like-minded groups that share and support their political interests (Vliegenthart et al. 2013: 396). Given the central role of political parties in parliamentary systems (Müller 2000; Sieberer 2006), I expect that parliamentarians' political objectives and their interactions with different types of interest groups run along partisan lines. The information provided by like-minded interest groups is supposed to support parliamentarians and their party groups in the formulation of politically and technically effective policies. The MPs can use the interest groups' political support to devise political strategies that can be more easily adopted and implemented (Hall and Deardorff 2006: 72-6). In line with this reasoning, Baumgartner et al.'s (2009: 132) and Burstein's (2014: 147) analyses of interest group advocacy in US policy-making show that the information provided by interest groups largely dealt with the importance of policy problems and the effectiveness and feasibility of policy proposals, but less with electoral concerns.

In the following, I distinguish three types of interest groups: labour unions, business associations and non-governmental organisations. The intensity of contacts that members of the Bundestag have with these groups is, in line with the political motivation outlined above, expected to systematically vary between parliamentarians from different political parties. Given their relative programmatic and ideological closeness, parliamentarians from political parties which take left-of-centre positions on the economic (left-right) 
dimension and that pursue a redistributive welfare state agenda (Kriesi 2012: 100) - socialists (DIE LINKE), social democrats (SPD) and the Greens (B90/ die Grünen) - are expected to have more intense contacts to labour unions. Parliamentarians from political parties which take right-of-centre positions on the economic left-right dimension and which pursue a relatively liberal economic policy agenda - CDU/CSU, FDP - are expected to seek information primarily from business interest groups. ${ }^{2}$ In addition, left-of-centre political parties also pursue post-material and ecological political agendas (Kriesi 2012: 100). Parliamentarians of these parties and in particular of the Greens, which accord high salience to post-material issues, are expected to seek information from NGOs more often than members of centre-right and liberal parties.

\section{Political support hypothesis:}

The further to the left (right) a political party locates itself, the more frequently a

MP of that party interacts with labour unions and NGOs (business associations).

The political support hypothesis on the influence of party affiliation on MPs' contacts to interest groups differs from large parts of the literature on EU interest group politics. In this literature, the effect of ideological factors on party-interest group interactions in EU policy-making is either not taken into account (Rasmussen 2012), or it is argued that parliamentarians in general entertain strong contacts to NGOs (Dür and Mateo 2012: 973; Eising 2007: 333) or to interest groups that represent 'encompassing' interests (Bouwen 2004: 345) while business interests and unions are thought to provide 'technical' information that is most relevant to the executive.

An alternative explanation does not predict extensive information contacts between legislators and interest groups that share political positions, but rather the opposite. According to the political screening perspective, members of parliament seek to establish contacts with a wide range of diverse interest groups to find out about potential opposition to a policy initiative and to adapt their positions to constituencies which represent considerable electoral potential (Hansen 1991: 12). In this theoretical perspective, interest groups focus their activities on legislators with opposed political interests in order to 'persuade' them to adopt a group's position (Austin-Smith and Wright 1994; Hall and Deardorff 2006; Hansen 1991). Interest groups lobbying parliamentarians who are politically close to them are said to aim at counterbalancing the lobbying of other groups (Austin-Smith and Wright 1994). In this perspective, contrary to the political support hypothesis above, legislators do not hold strong a priori policy preferences nor do they entertain stable alliances with like-minded interest groups. Instead, legislators seek the political support of various constituencies to win elections. Parliamentarians' information contacts should thus strongly vary across different types of interest groups and not concentrate on any one type of group. 


\section{Political screening hypothesis:}

There is no systematic empirical relationship between legislators' party-political left-right position and the intensity of their contacts to different types of interest groups.

While I do expect, in line with the political support hypothesis, that the information contacts of legislators from different political parties focus on specific types of interest groups, I do not claim that MPs interact exclusively with just one type of interest group. Sometimes legislators might exchange views with interest groups that hold opposing interests to learn more about their positions or to increase the acceptance of their political initiatives by acting in a politically inclusive way.

In the multiple regression analyses below, I control for a number of variables which could impact on the scope of the MPs' contacts to interest groups from a rational choice institutionalist perspective. First, I control for legislators' government and opposition status. Parliamentarians who are in opposition lack intra-party links to the executive which is directly involved in EU decision-making via the EU Council and has the bureaucratic means to follow EU developments (Wonka and Rittberger 2014). Members of the opposition might try to compensate for these disadvantages by intensifying their ties to interest groups ('govopp'). Moreover, parliamentarians' interactions with interest groups might systematically differ between MPs directly elected by a majority in their electoral district and those who entered the parliament via their party's list, since the former have stronger incentives to maintain close contacts to their constituencies (Stratmann and Baur 2002) ('election'). In addition, parliamentarians holding powerful positions in their parliamentary groups might have greater incentives to obtain information from interest groups than 'backbenchers. To control for this factor, I include a dummy variable identifying those MPs who acted as their party's spokesperson in a specific policy area ('obmann'). Finally, MPs' information acquisition might be affected by the importance parliamentarians subjectively attribute to EU policies for the success of their own political work ('EU salience') and the extent to which their area of legislative (committee) specialisation is affected by EU policies ('EU policy impact'). EU policy impact as understood here captures the extent to which parliamentary committees and their members deal with EU policies.

\section{Research design and data}

The data presented below was collected in an online-survey, which was carried out among all members of the 16th German Bundestag between January and October 2009 (see Wonka and Rittberger 2014). Parliamentarians were first contacted by email. To increase the response rate, email contacts were followed up by phone calls and a personal visit in the Bundestag. In order to make sure that all MPs had sufficient experiences in their parliamentary work 
the survey was carried out at the end of the legislative period. Ninety-eight of the 614 members of the 16th German Bundestag responded to the survey, which amounts to a response rate of $16.0 \%$. The 98 cases on which the empirical analysis is based provide innovative empirical information on legislators' demand for information from interest groups in EU multilevel politics. Most interest group research relies on interest groups' information on their lobbying activities. These studies can only indirectly assess the politicians' motives in these exchanges.

The sample is broadly representative of the partisan composition of the Bundestag (BT) (Table 1). Parliamentarians of the CDU/CSU (sample: 31.6\%; BT: $36.8 \%$ ) and DIE LINKE (sample: 7.1\%; BT: $8.8 \%$ ) are slightly underrepresented while members of the liberal FDP (sample: 16.3\%; BT: 9.9\%) are slightly overrepresented. In addition, parliamentarians in the sample were active in 21 Bundestag committees. The information presented below is therefore not biased towards activities and perspectives from members of specific committees, such as the European Affairs Committee (EAC). ${ }^{3}$ It is thus unlikely that parliamentarians' responses reflect the dynamics of specific policy areas. Moreover, the respondents vary considerably in their behaviour as well as their attitudes, indicating that the data and findings are not biased towards legislators of a particular (behavioural or attitudinal) type.

The frequencies of parliamentarians' information contacts are measured on a three-point scale ('never/seldom', 'occasionally', 'often/always', see Figure 1). To measure the independent variable of theoretical interest (parliamentarians' ideological orientation), I relied on a dummy variable (left parties) which pits leftist parties - DIE LINKE, B90/Die Grünen, SPD - against rightist parties (see Hypothesis 1). The information on the political parties' left-right placement was taken from Holger Döring and Philip Manow's (2012) Parlgov database. The dichotomous opposition variable separates members of the opposition parties (FDP, DIE LINKE, Bündnis90/Die Grünen) from parliamentarians who belonged to the governing majority (CDU/CSU, SPD) at the time of the survey. To assess the EU's policy impact on MPs' work, the committees in which the legislators in the sample are regular full members were identified. To measure the degree of EU policy impact, I draw on original data from the Bundestag administration on the number of EU documents received by the respective committee during the legislative term 2005-2009. These documents comprise

Table1. Composition of the 16th Bundestag (2005-2009) and survey response.

\begin{tabular}{lcccc}
\hline Party group & Parl. seats & Survey & Parl. seats (\%) & Survey (\%) \\
\hline CDU/CSU & 226 & 31 & 36.8 & 31.6 \\
SPD & 222 & 35 & 36.2 & 35.7 \\
FDP & 61 & 16 & 9.9 & 16.3 \\
DIE LINKE & 54 & 7 & 8.8 & 7.1 \\
Bündnis90/Die Grünen & 51 & 9 & 8.3 & 9.2 \\
$N$ & 614 & 98 & 100 & 100 \\
\hline
\end{tabular}


Table 2. Variables and descriptive statistics.

\begin{tabular}{lcccc}
\hline Variable & Range & Mean & SD & $\mathrm{N}$ \\
\hline Left parties & $0-1$ (dummy variable) & 0.52 & 0.50 & 98 \\
EU policy impact & $1.1-5.95$ (log) & 4.76 & 1.1 & 97 \\
Opposition & $0-1$ (dummy variable) & 0.33 & 0.47 & 98 \\
Salience & $0-10$ & 5.38 & 2.54 & 84 \\
Election & $0-1$ (dummy variable) & 0.39 & 0.49 & 98 \\
Obmann & $0-1$ (dummy variable) & 0.22 & 0.42 & 98 \\
\hline
\end{tabular}

EU legislation as well as consultation and other EU documents. The variable captures only those documents that were forwarded to the committee in charge after they were considered as relevant by the Bundestag administration and the EU spokespersons of all parliamentary groups. I took the natural log of the number of documents to normalise the distribution of values. The salience of the EU was measured by asking legislators about their assessments of the EU's importance for the success of their work. The variable was measured on an 11-point scale with the endpoints 'not important at all' (0) and 'very important' (10). Finally, information on whether a parliamentarian was directly elected to the Bundestag or entered it via their party's list and whether they acted as their parliamentary group's spokesperson in a specific field, was taken from the Bundestag's and the parliamentarians' homepages (see Table 2).

\section{Interest groups and partisan contacts of German MPs}

While legislators rely on diverse sources to obtain information on EU policies, Figure 1 shows also that members of the Bundestag consider interest groups to be important sources of information on EU policies. Among interest groups, German NGOs are most often contacted. This is in line with previous research which also found strong information contacts between parliamentarians and NGOs (Bouwen 2004; Dür and Mateo 2012, 2013). While German unions and business associations are contacted less frequently, about 50\% of the MPs in the sample still report contacting them 'often/always' or 'occasionally'. Moreover, MPs focus their information contacts on domestic interest groups. Information contacts to interest groups in other member states or to EU interest organisations are of limited or no importance at all. ${ }^{4}$ Their reliance on domestic interest groups reflects parliamentarians' incentives to entertain close contacts to electorally important constituencies in their country.

I will now turn to a first, bivariate assessment of the hypotheses formulated above. As proposed by the political support hypothesis, legislators entertain particularly strong information ties to interest groups that pursue similar political interests and which are part of legislators' core constituency (Figure 2): Parliamentarians from leftist parties - Die LINKE, SPD and B90/Die Grünen report more frequent contacts with German NGOs as well as with German 


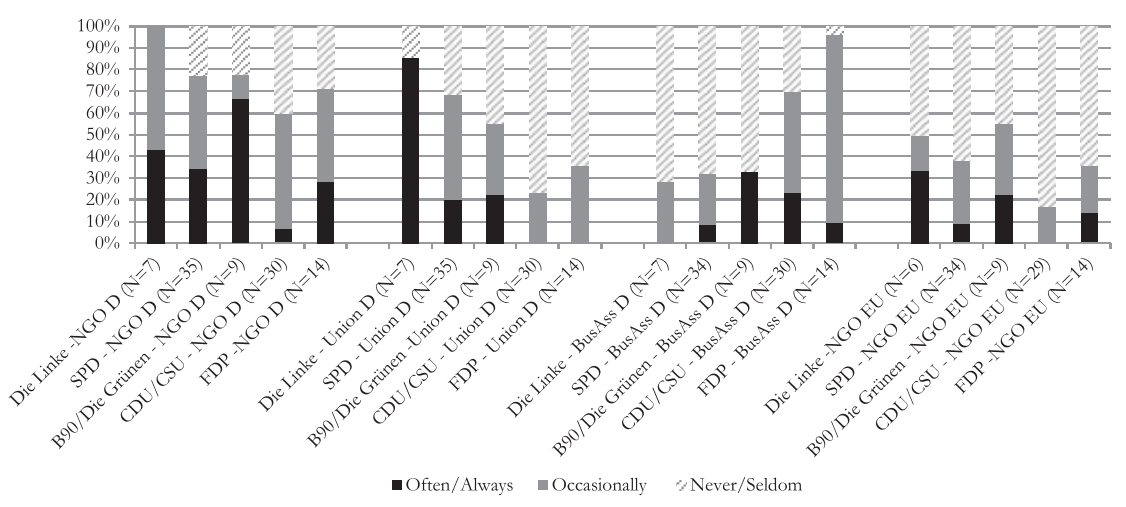

Figure 2. Frequency of contacts to different interest groups - reported by parties.

Note: The data was obtained from an online survey with members of the German Bundestag. Parliamentarians were asked the following question:'Please indicate how often you contact the below listed [actors] to obtain information on planned or current policies at the EU level.'

labour unions than legislators from centre-right parties (CDU/CSU and FDP). These, in turn, contact business groups more often. A non-parametric difference of means test (Kruskall-Wallis) shows that the differences in contact frequencies reported by parliamentarians from different political parties to German unions ( $\chi^{2}$ (with ties): 26.4, df: $4, p: 0.0001$ ) and business associations ( $\chi^{2}$ (with ties): 11.6, df: $4, p: 0.0207$ ) as well as to German NGOs ( $\chi^{2}$ (with ties): 12.187 , df: $4, p: 0.0160$ ) are statistically significant. The fact that the Social Democrats (SPD) and the Christian Democrats (CDU) formed a governing coalition at the time when the data was collected supports the interpretation that the reported contact frequencies result from differences in parties' and parliamentarians' ideological orientations. If information contacts to interest groups were driven by institutional roles and demands alone, we would not observe such differences in the information contacts between legislators of the two governing parties.

The political support character of legislators' EU-related information contacts to interest groups is also confirmed when relying on the MPs' self-placement on the (11 point) left (0)-right (10) scale. The more to the right legislators place themselves, the more frequently do they interact with German business associations (rho: 0.23 ; p: 0.05 ) and the less frequently do they contact NGOs from their country to obtain information on EU policies (rho: - 0.36 ; $p: 0.001$ ). The relationship is particularly strong for information contacts to German unions (rho: $-0.57 ; p: 0.0000$ ), whose frequency rises relatively sharply the more left-leaning MPs consider themselves to be. These findings provide individual-level empirical support for the 'political support' hypothesis discussed above.

I will now turn to a more systematic test of the political support and the political screening hypotheses. To estimate the empirical relationship between the independent variables and the ordinal dependent variables that measure 
MPs' information contacts with specific group types, I rely on ordered logistic regression models. ${ }^{5}$

For each group type (unions, business, German NGOs, EU-level NGOs) I estimate three models. Following a base model that includes only party ideology, the subsequent model adds a number of controls. The third model includes also the information on the subjectively perceived salience of EU politics for MPs' political success which is missing for a number of parliamentarians so that the number of observations in this model is slightly reduced. I take into account that the behaviour reported by parliamentarians might not be fully independent, in particular when it comes to legislators from the same political party. Due to the relatively small number of parties, however, it is not advisable to estimate clustered standard errors. Yet partisan effects on legislators' interactions with interest groups are at the centre of analytical attention in this paper. To be sure that the following empirical analysis captures these effects I conducted additional robustness checks by including dummy variables for individual political parties in the statistical models (not reported in Table 3). These also account for potential non-independence of reported behaviour by MPs from the same political party. The estimation of party effects with dummy variables for individual parties (the three leftist parties in the NGO and Union models; the two rightist parties in the business model) rather than distinguishing only between left- and right-wing parties as in Table 3 yielded the same substantive results.

The results presented in Table 3 provide strong evidence in favour of the political support hypothesis: parliamentarians from parties that pursue a leftof-centre political agenda - the Left, the Greens and the Social Democrats report having more extensive information contacts with German labour unions as well as with German NGOs and EU NGOs than right-of-centre political parties (CDU, FDP). The results on legislators' interactions with business associations also provide evidence in favour of the political support hypothesis. Parliamentarians of centre-right parties - CDU and FDP - have stronger information ties to German business groups than do parliamentarians of the left-wing parties, as indicated by the negative sign of the (left) party dummy. Legislators' information contacts to interest groups indeed seem to be motivated by their political motive to obtain information from those interest groups that share their political positions and can help them to pursue their political objectives.

Moreover, a comparison of the sizes of the regression coefficients of the left parties variable in the four models shows that the effects of party ideology are stronger for legislators' contacts to labour unions and business associations than they are for their contacts to German and EU NGOs (Table 3). This indicates, in line with the literature, that NGOs in general have fairly good access to parliamentarians in EU policy-making (Dür and Mateo 2012). At the same time, however, the fact that legislators' party group affiliations also have effects on 


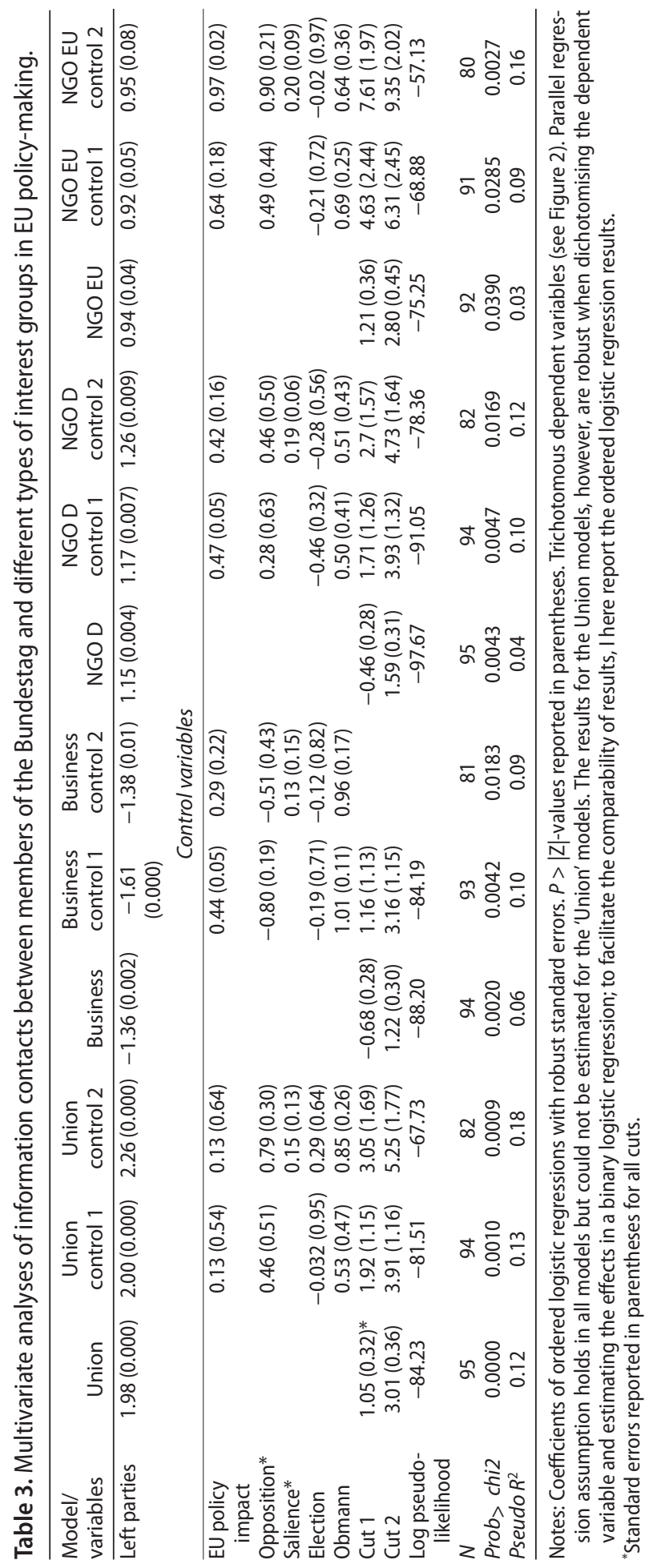


their interactions with NGOs shows that these interactions are also driven by party-political motives. Legislators' from rightist parties entertain less extensive contacts to NGOs. This finding undermines the argument that parliamentarians in general are interested in information provided by NGOs because they provide them with information that represents the public's or citizens' general interests (Dür and Mateo 2012: 973).

The party effect holds also when controlling for variables that might be expected to have a systematic effect on the scope of parliamentarians' information contacts to interest groups: the legislators' governing or opposition status, the level of the EU's policy impact in their area of legislative specialisation, whether parliamentarians acted as their parliamentary group's spokesperson in a specific policy area and whether a parliamentarian has entered the Bundestag via the party list or has been directly elected in their electoral district. In addition, I control for the salience parliamentarians subjectively attribute to EU politics more generally.

Parliamentarians' opposition or governing status does not seem to systematically affect their contact intensities with interest groups. Nor does the direct election of MPs into the Bundestag. Thus, at least with the data used in this paper, I could not find support for the conjecture that parliamentarians that were directly elected are in closer contact with constituencies in their electoral district (Stratmann and Baur 2002). The extent to which a parliamentarian's area of legislative specialisation is affected by EU policies as well as the importance which an MP attributes to EU politics for the success of his own political work are positively related to his information contacts to interest groups. But results are mixed, since the estimates do not meet conventional levels of statistical significance in some of the models.

\section{Discussion}

This paper started from the argument that information is not necessarily a scarce resource for politicians more generally and for members of the German Bundestag in EU policy-making more specifically. Other studies have shown that parliamentarians draw on different media, parliamentary debates as well as documents from their legislative committees and other institutions to obtain politically relevant information (Burstein 2014: 98; Hall and Deardorff 2006). In this paper I focused on another strategy which legislators use to acquire information on policies that are planned or already negotiated in the EU's legislative process: legislators' direct interactions with different types of interest groups. To develop my argument on the political character of the interactions between parliamentarians and interest groups, these interactions were placed in the context of parliamentarians' intra-party information exchanges. By investigating the parliamentarians' information-seeking strategies, the analytical focus is on the demand-side of politicians' relationships to interest groups in policy-making. 
Figure 1 shows that parliamentarians rely heavily on intra-party channels to other members of the legislature and the executive (see Wonka and Rittberger 2014) as well as to different types of interest groups in order to put themselves in a better position to assess the political and regulatory implications of EU policies (see Schneider et al.2014: 416-18). Both the bivariate and the regression analyses provide empirical evidence that the information-gathering strategies of the members of the German Bundestag in EU policy-making are systematically shaped by partisan ideologies and electoral incentives: instead of screening the positions of a broad and diverse set of interest groups, as suggested by the screening hypothesis (Austin Smith and Wright 1994; Hall and Deardorff 2006: 71-2; Hansen 1991: 12), legislators entertain particularly strong political ties to those types of interest groups that are part of their core constituency and broadly share their political goals. These politically like-minded interest groups provide information that supports legislators' own political positions and helps them to draft technically, politically and economically workable laws. The findings therefore confirm the political support hypothesis formulated above and Hall and Deardorff's (2006) legislative subsidy argument on which it rests.

Moreover, the findings of this paper qualify those studies which argue that NGOs in general enjoy privileged access to parliamentarians while business interests primarily interact with executive and administrative actors (Bouwen 2004: 345; Dür and Mateo 2012: 973; Eising 2007: 333). NGOs indeed seem to enjoy high levels of access to parliamentarians (Figures 1 and 2). However, parliamentarians' interactions with them are also driven by their partisan ideology (Table 3). Focusing on another set of actors (parliamentarians) and drawing on a different kind of data (survey of parliamentarians), the findings presented here support recent interest group studies which found that political parties' political ideology has a systematic effect on the contact intensity (Otjes and Rasmussen 2017) and positional closeness (De Bruycker 2016) which different types of interest groups report to have with political parties (see also Eising et al. 2017).

However, the argument made on legislators' information-seeking strategies does not imply that parliamentarians exclusively talk to like-minded interest groups and that they never give in to the pressure of groups that pursue different political goals. Of course, parliamentarians also have to engage with interest groups that advocate opposing interests. But they are not passive support seekers who are constantly screening potential constituencies in order to adapt their political preferences accordingly. Rather, parliamentarians attempt to build trustful political alliances with interest groups that allow them to advance their own political goals. ${ }^{6}$

It is in this sense that they primarily rely on interest groups with shared political interests as these are of greatest help in this regard. Hall and Deardorff put this nicely by stating that

[t] heir budget constraint thus relaxed by lobbyists' assistance, already likeminded legislators act as if they were working on behalf of the group when in fact they 
are working on behalf of themselves. In this sense our theory is 'budget-centered' rather than 'preference-centered'. (Hall and Deardorff 2006: 69)

The confirmation of the political support hypothesis invites a reconsideration of interest groups' influence on parliamentarians' positions and voting behaviour. If parliamentarians in particular and politicians more generally rely primarily on the information of politically close interest groups, the influence of interest groups on parliamentarians might not be as great as sometimes assumed by interest group scholars. However, based on the empirical information used in this paper, a reassessment of the consequences of information provided by interest groups on the political positions taken by legislators and their behaviour cannot be made.

Finally, regarding the generalisability of the findings in this paper, one might argue that, given the relatively low level of political contestation in most EU policy-making processes (Wonka et al. 2015) and the limited electoral salience of EU policies for national political parties (Green-Pedersen 2012; Hoeglinger 2016), an investigation of information-gathering strategies of parliamentarians in national policy-making would find even stronger effects of partisan ideology on interactions between party politicians and different types of interest groups.

\section{Conclusion}

The findings of this article have a number of general implications for theories of interest group politics. Theoretical approaches which treat interactions between interest groups and politicians as exchanges in which groups trade information for access or influence on political decisions should move beyond broad conceptualisations of these exchanges in which institutions as such are often argued to have a specific informational demand function (Berkhout 2013: 2379; Bouwen 2004; Dür and Mateo 2012: 973). The presented results show that the heterogeneous political preferences of decision-makers inside an institution should be taken into account. There is not one uniform demand by members of the Bundestag, but informational demand varies systematically and in a theoretically explainable way across parliamentary groups. Moving from institutions to functional and/or political groups of decision-makers inside institutions allows us to theoretically account for specific political motivations and the political nature of information as well as the politics of information exchange. Looking beyond institutional demands might be particularly relevant for those (electoral) institutions in which partisan interests play an important role and less so in bureaucracies whose personnel might be more strongly driven by specific functional and sectoral concerns. However, even in and between bureaucratic institutions, the staff's preferences might vary, because of different perspectives on policies and varying organisational incentives related to different policy outcomes. 
In addition, scholars treating information as an important access or power resource for interest groups should recognise the multiplicity of politicians' information sources in order not to overestimate the possible influence resulting from interest groups' information provision. This article shows that explicitly taking into account the complementary role of political parties and interest groups in interest intermediation contributes to explaining the contact intensity and the strength of political ties between politicians and different types of interest groups. Exchange theories of interest group politics often distinguish between technical information and political information, with the latter referring to electoral support and support in the effective implementation of policies and the former to legal, administrative or engineering aspects. However, the above results indicate that the political character of information must be acknowledged and that our theoretical thinking should move beyond a (perhaps implicit) functionalist understanding of technical information which sometimes seems to assume that policy-makers are interested primarily in technically effective policies and less so in policies of a specific (party-)political nature. Explicitly taking into account their political dimension should help us not only to better explain the scope of information exchanges but also the resulting political dynamics and conflicts in policy-making.

Finally, this paper has taken a static analytical and empirical perspective on interactions between parliamentarians from different political parties and different types of interest groups. This perspective allows us to assess the extent to which political considerations affect the more general patterns of information exchange between these actors. However, it does not shed light on trade-offs and compromises which political parties and policy-makers might have to accept during the contestation and deliberation as well as during the adoption of specific policies. It could therefore be analytically and empirically fruitful to complement and extend the analysis of the general patterns of information exchange such as this one with the resulting political alliances in specific policy-making processes. Such a policy-centred research design would also take into account the effects that potentially important contextual factors, such as the level of interest group and political party mobilisation and the broader political and media attention to policy-making processes, have on the interactions between politicians and interest groups. In addition, such a dynamic perspective could investigate if information exchanges between parliamentarians and interest groups change across different stages of the decision-making process, i.e. during the formulation of policies and when policies are voted upon.

\section{Notes}

1. The (Spearman's rho) correlation between information and political coordination contacts of members of the Bundestag with other political actors varies between 0.65 (German business associations; $p=0.0000 ; N=83$ ) and 0.77 (German labour unions; $p=0.0000 ; N=84$ ). 
2. Parties' left-right positioning is taken from Holger Döring and Philip Manow's ParlGov database (2012), which, on a 0 (left) to 10 (right) scale, locates the five parties as follows: Die Linke (1.2), Bündnis 90/Die Grünen (2.9), SPD (3.6), FDP (5.9), CDU (6.3) and CSU (7.3).

3. Only $9 \%$ of the respondents are active in the EAC.

4. Contacts to NGOs, unions and business associations in other member states or at the EU level for which less than 30\% of MPs report regular (always/ frequent + occasional) contacts are not reported in Figure 1.

5. Some authors suggest relying on ordinary least squares (OLS) regression models which are mathematically less demanding and more robust even with noncontinuous dependent variables with a limited range (Angrist and Pischke 2009). I therefore also estimated OLS regression and binary logistic regression models (dichotomous dependent: 'always/very often' and 'occasionally' vs 'never/seldom'). The coefficients and standard errors hardly change across alternative estimation techniques and, most importantly, the effect estimates of the partisan variable which is of central theoretical interest in this paper remain substantively unchanged.

6. Kohler-Koch et al. (2017) advance this argument for the relations among business interest groups and political institutions.

\section{Acknowledgements}

I would like to thank Patrick Bernhagen, Rainer Eising, Daniel Rasch, Patrycia Rozbicka and the reviewers for detailed comments on earlier versions of this manuscript. Helpful comments were also provided by Holger Döring, Alexander Gattig, Sebastian Haunss, Valentin Schröder, Laura Seelkopf and Michael Tatham. The data used in this paper was collected in a project that I co-directed with Berthold Rittberger.

\section{Disclosure statement}

No potential conflict of interest was reported by the author.

\section{Funding}

This work was supported by the German Science Foundation [grant number DFG, RI 1972/1-1]. 


\section{References}

Angrist, Joshua D. and Stefan Pischke (2009). Mostly Harmless Econometrics. An Empiricist's Companion, Princeton, NJ: Princeton University Press.

Auel, Katrin, and Arthur Benz (2005). 'The Politics of Adaptation: The Europeanisation of National Parliamentary Systems', Journal of Legislative Studies, 11:3/4, 372-93.

Austen-Smith, David, and John R. Wright (1994). 'Counteractive Lobbying', American Journal of Political Science, 38:1, 25-44.

Baumgartner, Frank R., Jeffrey M. Berry, Marie Hojnacki, Beth L. Leech, and David C. Kimball (2009). Lobbying and Policy Change. Who Wins, Who Loses, and Why, Chicago, IL: Chicago University Press.

Berkhout, Joost (2013). 'Why Interest Organizations Do What They Do: Assessing the Explanatory Potential of 'Exchange' Approaches', Interest Groups \& Advocacy, 2:2, 227-50.

Beyers, Jan (2002). 'Gaining and Seeking Access: The European Adaptation of Domestic Interest Associations', European Journal of Political Research, 41, 585-612.

Beyers, Jan (2004). 'Voice and Access. Political Practices of European Interest Associations', European Union Politics, 5:2, 211-40.

Bouwen, Pieter (2004). 'Exchanging Access Goods for Access: A Comparative Study of Business Lobbying in the European Union Institutions', European Journal of Political Research, 43, 337-69.

Burstein, Paul (2014). American Public Opinion, Advovacy, and Policy in Congress. What the Public Wants and What It Gets. Cambridge: Cambridge University Press.

Cusack, Thomas R., Torben Iversen, and David Soskice (2007). 'Economic Interests and the Origins of Electoral Systems', American Political Science Review, 101:3, 373-91.

De Bruycker, Iskander (2016). 'Power and Position: Which EU Party Groups Do Lobbyists Prioritize and Why?', Party Politics, 22:4, 552-62.

Döring, Holger, and Philip Manow. 2012. Parliament and Government Composition Database (ParlGov): An Infrastructure for Empirical Information on Parties, Elections and Governments in Modern Democracies. Version 12/10-15 October 2012.

Dür, Andreas, and Gemma Mateo (2012). 'Who Lobbies the European Union? National Interest Groups in a Multilevel Polity', Journal of European Public Policy, 19:7, 969987.

Dür, Andreas, and Gemma Mateo (2013). 'Gaining Access or Going Public? Interest Group Strategies in Five European Countries', European Journal of Political Research, $52,660-686$.

Eising, Rainer (2004). 'Multilevel Governance and Business Interests in the European Union', Governance: An International Journal of Policy and Administration, 17:2, 211-245.

Eising, Rainer (2007). 'Institutional Context, Organizational Resources and Strategic Choices, Explaining Interest Group Access in the European Union', European Union Politics, 8:3, 329-362.

Eising, Rainer, Daniel Rasch, Patrycja Rozbicka, Danica Fink-Hafner, Mitja Hafner-Fink and Meta Novak (2017). 'Who Says What to Whom? Alignments and Arguments in EU Policy Making', West European Politics. doi: 10.1080/01402382.2017.1320175.

Finke, Daniel and Tanja Dannwolf (2013). 'Whistle Blowing and Opposition Control: Parliamentary Scrutiny in the European Union', European Journal of Political Research, $52,715-46$. 
Green-Pedersen, Christoffer (2012). 'A Giant Fast Asleep? Party Incentives and the Politicization of European Integration', Political Studies, 60, 115-130.

Hall, Richard L., and Alan V. Deardorff (2006). 'Lobbying as Legislative Subsidy', American Political Science Review, 100:1, 69-84.

Hansen, John Mark (1991). Gaining Access. Congress and the Farm Lobby, 1919-1981, Chicago, IL: The University of Chicago Press.

Hoeglinger, Dominic (2016). 'The Politicisation of European Integration in Domestic Election Campaigns', West European Politics, 39:1, 44-63.

Jones, Bryan D., and Frank R. Baumgartner (2005). The Politics of Attention. How Government Prioritizes Problems. Chicage, IL: University of Chicago Press.

Kohler-Koch, Beate, Peter Kotzian and Christine Quittkat (2017). 'The Multi-Level Interest Representation of National Business Associations,' West European Politics. doi: 10.1080/01402382.2017.1303244.

Krehbiel, Keith (1991). Information and Legislative Organization. Ann Arbor: University of Michigan Press.

Kriesi, Hanspeter (2012). 'Restructuring the National Political Space: The Supply Side of National Electoral Politics', in Hanspeter Kriesi et al. (eds.), Political Conflict in Western Europe, Cambridge: Cambridge University Press, 96-126.

Lijphart, Arend (1999). Patterns of Democracy. Government Forms and Performance in Thirty-Six Countries. New Haven, CT: Yale University Press.

Lupia, Arthur, and Mathew D. McCubbins (2000). 'Representation or Abdication? How Citizens Use Institutions to Help Delegation Succeed', European Journal of Political Research, 37, 291-307.

Marshall, David (2015). 'Explaining Interest Group Interactions with Party Group Members in the European Parliament: Dominant Party Groups and Coalition Formation', Journal of Common Market Studies, 53:2, 311-29.

Milbrath, Lester W. (1963). The Washington Lobbyists. Chicago, IL: Rand McNally \& Company.

Müller, Wolfgang C. (2000). 'Political Parties in Parliamentary Democracies: Making Delegation and Accountability Work', European Journal of Political Research, 37, 309-33.

Otjes, Simon, and Anne Rasmussen (2017). 'The Collaboration between Interest Groups and Political Parties in Multi-Party Democracies: Party System Dynamics and the Effect of Power and Ideology', Party Politics, 23:2, 96-109.

Proksch, Sven-Oliver, and Jonathan B. Slapin (2010). 'Parliamentary Questions and Oversight in the European Union', European Journal of Political Research, 50:1, 53-79.

Rasmussen, Anne (2012). 'Interest Group-Party Interaction in EU Politics', Party Politics, 18:1, 81-98.

Rasmussen, Anne, and Gert-Jan Lindeboom (2013). 'Interest Group-Party Linkage in the Twenty-First Century: Evidence from Denmark, the Netherlands and the United Kingdom', European Journal of Political Research, 52, 264-89.

Schneider, Ellen, Berthold Rittberger and Arndt Wonka (2014). 'Adapting to Europe? Regional MPs' Involvement in EU Affairs in Germany', Regional and Federal Studies, 24:4, 407-27.

Siaroff, Alan (1999). 'Corporatism in 24 Industrial Democracies: Meaning and Measurement', European Journal of Political Research, 36, 175-205.

Sieberer, Ulrich (2006). 'Party Unity in Parliamentary Democracies: A Comparative Analysis', Journal of Legislative Studies, 12:2, 150-78.

Stratmann, Thomas, and Martin Baur (2002). 'Plurality Rule, Proportional Representation, and the German Bundestag: How Incentives to Pork-Barrel Differ across Electoral Systems', American Journal of Political Science, 46:3, 506-14. 
Vliegenthart, Rens, Stefaan Walgrave, and Brandon Zicha (2013). 'How Preferences, Information and Institutions Interactively Drive Agenda-Setting: Questions in the Belgian Parliament, 1993-2000', European Journal of Political Research, 52, 390-418.

Winzen, Thomas (2012). 'National Parliamentary Control of European Union Affairs: A Cross-National and Longitudinal Comparison', West European Politics, 35:3, 657-72.

Wonka, Arndt, and Berthold Rittberger (2014). 'The Ties That Bind? Intra-Party Information Exchanges of German MPs in EU Multi-Level Politics', West European Politics, 37:3, 624-43.

Wonka, Arndt, Iskander De Bruycker, Dirk De Bièvre, Caelesta Braun and Jan Beyers (2015). 'The Scope of Mobilization and Patterns of Conflict in EU Interest Group Politics', unpublished manuscript. 


\title{
Imperfect public goods and the logic of selective exit in EU interest organisations
}

\author{
Rainer Eising
}

\begin{abstract}
How do national members react to performance failures of EU-level interest groups? Albert Hirschman suggested two responses: exit and voice. Building on this distinction, the article develops the category of selective exit which denotes members' interest representation outside the boundaries of the EU-level interest organisation in response to performance failures. Selective exit enables members to raise voice from within and exert pressure from outside the group. The empirical test of this proposition draws on 100 interviews with national interest groups which provide evidence on the lobbying performance of EU-level groups on $20 \mathrm{EU}$ directive proposals. Exact logistic regressions analyse their responses to the quality of information supply by the EU-level group and the congruence of their preferences with the EU-level group's common position. The findings demonstrate that members join coalitions and participate in media debates to counter perceived performance failures. The conclusion summarises the findings and points out avenues for further research.
\end{abstract}

European Union-level interest groups have several tasks. They inform their members about EU legislation, help them to participate in EU politics, aggregate their interests, and represent them at the EU institutions (see also Berkhout et al. 2017). However, their heterogeneous national membership can hamper the formulation of joint positions as much as the effective representation of member interests. How do their members respond to such performance deficits? Albert Hirschman (1970) suggested two main responses to organisational failures: voice and exit. Discontented members demand remedial change or leave the organisation.

Building on Hirschman's distinction, I develop the category of selective exit. I argue that discontented members do not usually leave EU-level groups because the costs of membership are small and those of exit potentially large. It is more 
common to voice discontent within the EU-level groups and also use parallel channels of interest representation: the participation in media debates and coalitions as well as the direct lobbying of the European Commission and the European Parliament.

That national interest groups utilise these means to impact on EU legislation is hardly news. Frequently, these tactics are depicted as rational adaptation to the institutional context of the EU multilevel system. However, this does not account for the high degree of variance in the usage of these channels and also leaves open if they are explicit responses to EU-level groups' performance gaps. I focus on their two core functions - the provision of information to their members and the formation of policy positions - to study if performance gaps of EU-level groups lead to a selective exit of their national members. The weaker the information flow to their members and the more the EU-level groups' common positions differ from their members' preferences on EU policy proposals, the more these should seek to mobilise additional support for their causes and lobby the EU institutions themselves.

The next section presents basic theoretical ideas about loyalty, exit, and voice in EU-level interest organisations. The subsequent empirical analysis draws on semi-standardised interviews with 100 national interest groups on their representation of interests with respect to $20 \mathrm{EU}$ policy proposals. First, I present data on the relevance of exit and voice in EU-level groups. Then, I give an overview of the information flow and the positions formed in these groups as well as the use of interest representation strategies by their national members. Thereafter, I utilise exact logistic regressions to account for potential selective exit strategies: the formation of coalitions, the participation in media debates as well as the lobbying of the European Commission and the European Parliament. The findings suggest that the formation of coalitions and media strategies may be considered selective exit strategies whereas the recourse to inside lobbying at the EU level is independent of the performance of EU-level groups. The conclusion discusses the consequences of selective exit for EU-level interest groups.

\section{Selective exit in the EU interest group system}

In EU policy-making, the 'national route' has been the 'tried and tested ground' of many domestic interest organisations (Greenwood 2003: 39). But as the EU member states increasingly lost their capacity to veto EU policies, national social and economic actors with a stake in EU policies have extended their reach to the EU level (e.g. Richardson 2006). These actors have great incentives to join EU-level interest groups because the European Commission privileges consultation with these groups (Kohler-Koch 1992) and nurtures a great variety of European interests (Mahoney and Beckstrand 2011). 
Like other interest organisations, EU-level groups are said to produce public goods. The theory of collective action asks whether actors with similar interests will contribute to forming such groups (Olson 1965). Self-interested actors may decide not to engage in the formation of these groups if they can free-ride on their public goods. Olson's (1965: 51) well-known solution to that problem is the production of selective incentives which benefit only members. Several studies provide evidence that the policy information EU-level interest groups produce is a crucial selective good and an important reason to join them (e.g. Aspinwall and Greenwood 1998, Eising 2009). Nonetheless, EU-level interest groups have above all been created to produce position papers as public goods and represent their members' interests vis-à-vis the EU institutions (see also Berkhout et al. 2017).

Membership in EU-level groups helps domestic interest groups to manage risks in the EU's complex institutional environment. It allows them to monitor incoming EU legislation, supports their exchange of information with other members, and strengthens the representation of their interests at the EU institutions. For national interest groups, the question is not whether to organise interests at all but how best to represent them in EU policy-making (Jordan 1998). The annual subscription fee of EU-level groups tends to be less costly than the in-house production of the goods they provide (Greenwood 2002: 242-9) so that many national groups rely heavily on EU-level groups for information on EU legislation and for representing their interests at the EU level.

These insights explain the proliferation of EU-level interest organisations and the narrow bandwidth of their functions. But they account less well for the varied strategies of national interest groups to influence EU legislation. Classic studies indicate the general options: Streeck and Schmitter (1994: 215) draw attention to 'a wide range of choices among different paths of access to the Community's political center'. Pollack (1997) demonstrates that the EU multilevel system provides (diffuse) interest groups with multiple points of access which they use effectively. Traxler and Schmitter (1994: 52) highlight that national interest groups and large corporations tend to bypass EU-level interest groups, representing their positions on EU legislation directly at the EU institutions. Other scholars analysed members' initiation of organisational reforms in EU business interest groups (Cowles 1997). The association between important changes in socio-economic context and organisational changes was also scrutinised (e.g. Grote et al. 2008). Empirical studies indicate that most national interest groups focus their efforts on national political institutions, but that a substantial portion of them also resorts to direct lobbying of the EU institutions, joins coalitions with other groups, and engages in media debates as well as other tactics to affect EU legislation (e.g. Beyers 2004; Dür and Mateo 2016; Eising et al. 2017). According to these studies, the direct lobbying of EU institutions by national interest organisations is conditional upon a variety of factors such as group types (business vs. citizen groups), organisational 
features such as financial resources, the embeddedness of groups in domestic contexts and interest mediation, issue characteristics such as the salience, Europeanisation, or technicality of issues as well as interest groups' alignments with political institutions.

However, they remain woolly on the question of to what extent the strategic choices of national interest groups depend on the performance of EU-level groups. This is surprising because many scholars highlight the difficulties EU-level groups have to form joint positions in the face of a heterogeneous, cross-national membership (e.g. Greenwood 2002; Haas 1958; Traxler and Schmitter 1994: 52). To fill this lacuna, I analyse which strategies members employ in response to performance gaps of EU-level groups.

In correspondence with the previous literature, I depart from the assumption that domestic interest groups employ a default strategy when seeking to impact on EU legislation: They represent their interests directly vis-à-vis the national government which has a seat on the EU Council and, as cost-conscious actors, rely on 'their' EU interest group(s) to represent their interests at EU level. Stressing this membership perspective, I employ Hirschman's seminal responses to organisational failures - loyalty, exit, and voice - as a theoretical yardstick when accounting for the strategic responses of discontented members. Hirschman (1970: 1) suggested that his ideas do not only apply to firms and consumers but can be extended to interest groups. He also draws attention to the effects that the public goods these organisations provide have on members (Hirschman 1970:104).

Among his three main concepts, loyalty means a 'considerable attachment' to the organisation (Hirschman 1970: 77) which, however, is tied to the expectation that its dysfunctional behaviour 'can be moved again in the right direction' (Hirschman 1970: 78-9). Helping them to survive by keeping 'exit at bay' (Hirschman 1970: 78) and activating voice, loyalty gives organisations some slack before giving way to voice or exit (Hirschman 1970: 11).

In the economic marketplace, exit is the main response of unsatisfied customers (Hirschman 1970: 33) to poor performance by firms (Hirschman 1970: 38). They buy the products of a competing firm rather than raise voice against a specific producer. Especially in the political marketplace, to exit means to 'denounce and fight the organization from without instead of working for change from within' (Hirschman 1970: 104). However, members of an interest group cannot be sure to obtain more information and a better representation of their interests if they leave this group such that 'exit is normally entirely outside the horizon of the member' (Hirschman 1970: 88). That national members of EU-level interest organisations commonly use 'threats of exit ... to coerce their representatives into pluralist responsiveness', as some authors claim (Streeck and Schmitter 1994: 215), seems doubtful because the credibility of such threats depends on the availability, quality, and costs of alternatives. 
Interest groups produce collective goods through their formulation of joint positions which further biases members' choices towards voice rather than exit. According to Hirschman, leaving organisations providing public goods is supposedly ineffective: 'In spite of exit one remains a customer of the output or at least of its external effects from which there is no escape' (Hirschman 1970: 104). However, there are only very few pure public goods. And many interest groups provide only imperfect public goods. I argue that, in these circumstances, discontented members employ strategic options that are located outside the boundaries of interest organisations and enable them to raise both voice from within and exert pressure from without. I shall call these alternatives that fall short of full exit - selective exit strategies.

The utility of position papers as 'public goods' depends on their reception by policy-makers and their consistency with members' preferences. Position papers far away from members' preferences may carry substantial internal costs. Members threatened by these costs also seek other ways than voice to argue for their own causes and to hinder a favourable reception of this 'public good' by policy-makers. Their exit from the EU-level group can be selective and issue-specific. As position papers need not be supplied by a monopoly provider, they can buy the 'product' of interest representation in the form of a private good from political consultants, advocate their private position directly to EU institutions, or generate a competing collective good by forming coalitions with other actors or mobilising citizen support through the press. More resourceful members should have a greater ability to resort to selective exit. Typical members of EU-level interest organisations such as national interest groups, large firms, and institutions tend to have their own public affairs capacities and are well prepared for selective exit. This is more difficult for less well-endowed individuals who have joined interest groups in support of a humanitarian, social, or environmental cause.

Selective exit denotes strategies of interest representation outside the boundaries of the interest organisation by one or several members. Of course, members' strategies outside an EU-level organisation such as the direct lobbying of national institutions may be a routine affair or aim at complementing the EU-level group's activities rather than at counteracting them. Therefore, it must be stressed that selective exit strategies form explicit responses to performance gaps of interest organisations. I expect that such performance gaps result in members' direct lobbying of the European Commission and the European Parliament because these are the EU-level groups' main addressees in EU policy-making and in members' formation of coalitions and presence in the media. In other words, members will aim at mobilising additional actors in support of their positions to increase and strengthen their 'policy side' in EU legislation (on that term, see Baumgartner et al. 2009). As part of their default strategy, they will also lobby national institutions irrespective of the performance of EU-level groups. 
According to Hirschman (1970: 30), voice is 'any attempt at all to change ... an objectionable state of affairs', whether through petition, appeal, or other 'types of actions and protests', including those meant to 'mobilize public opinion.' ${ }^{1}$ Voice becomes more important the more uncertain the success of and the less feasible exit is. Its usage in interest groups is shaped by the intra-organisational mechanisms of voice. Even though the incorporation of members in their governing bodies varies (Berkhout et al. 2017), in many EU-level groups members have an important say in decision-making bodies, committees, and delegations such that they use voice rather than exit in response to performance gaps. Voice in interest groups can take on a variety of forms, such as the request to adopt a certain policy position or the demand for organisational change. Uncertainty about the positions they may advocate and the costs and benefits these imply is a strong incentive to have a say in the production of the EU-level groups' position papers. Selective exit may then be viewed as a response to the lack or failure of voice in these organisations.

Table 1 displays major properties of Hirschman's three mechanisms within interest groups. The empirical analysis in the next section focuses on the selective exit strategies.

Based on the above arguments, I put the following two hypotheses to the test:

Hypothesis 1: A poorer flow of information leads members to join coalitions, lobby EU institutions directly, and participate more in media debates.

Hypothesis 2: Members whose preferences differ from the common position formed in the EU-level group are more likely to join coalitions, lobby EU institutions directly, and participate in media debates than members with congruent preferences.

The following sections investigate to what extent their members engage in selective exit strategies when EU interest groups lag behind in performance.

\section{Information flow, positions, and selective exit: research design and data}

The empirical analysis is based on data gathered within the context of the INTEREURO project (Beyers et al. 2014; http://www.intereuro.eu ). It draws on

Table 1. Loyalty, exit, and voice in interest group systems.

\begin{tabular}{llc}
\hline Loyalty & \multicolumn{1}{c}{ Exit } & \multicolumn{1}{c}{ Voice } \\
\hline $\begin{array}{l}\text { Remain member without } \\
\text { articulation of and despite } \\
\text { discontent }\end{array}$ & Exit from the interest group & $\begin{array}{c}\text { Presence in decision-making } \\
\text { bodies, committees, delega- } \\
\text { tions } \\
\text { Articulation of discontent and } \\
\text { reform demands }\end{array}$ \\
& $\begin{array}{l}\text { Withdrawal of resources } \\
\text { Formation of a new group/Joining } \\
\text { of an alternative group } \\
\text { Selective exit strategies }\end{array}$ & \\
\hline
\end{tabular}

Source: Own characterisation based on Hirschman (1970). 
100 interviews with representatives of national interest groups in Germany, the Netherlands, the United Kingdom, Sweden, and Slovenia that were conducted in 2013 and 2014. The study covers those 71 national groups that were members in at least one EU-level interest organisation and omits the 29 national groups that did not join EU-level groups. Drawing on issue-based sampling and information, I study the potential selective exit strategies of these groups with respect to $20 \mathrm{EU}$ directive proposals which the European Commission tabled between 2008 and 2010. Of all directive proposals in that period these 20 received the greatest attention in both EU-wide (Agence Europe, European Voice) and national media (Le Monde, Frankfurter Allgemeine Zeitung, Financial Times), ensuring the relevance of these proposals to both EU-level and national interest groups. They cover distributive and regulatory policies, and among them are proposals for market integration as well as social regulation. They include directives in the energy and climate package, financial market regulation as well as in the areas of health policy, asylum policy, animal protection, etc. While not covering all EU policy areas, they allow for generalisations across policy areas. The interview partners were selected across the 20 proposals, the five member states, and based on their position towards the proposed directive (opposed or supportive). The interviews were semi-structured and contained questions about the controversial issues, the strategies of the interest groups, their organisational characteristics, their positions on the directives and issues, their influence, as well as their relation towards the EU associations. They lasted between 45 and 120 minutes.

The five countries include two large and three small nations, and among them are four prosperous north-western EU member states and one less prosperous southern European member state. The countries have also different systems of interest representation. Germany, Sweden, Slovenia, and the Netherlands are corporatist whereas the United Kingdom has pluralistic patterns of interest mediation (Lijphart 2012; Lukšič 2012).

I begin by describing exit and voice in the EU-level groups as well as presenting data on the suggested default strategy of national groups in the EU multilevel system. The data corroborate that, to members of EU-level groups, exit is a measure of last resort. In 2017 at least $95 \%$ of the national actors in the following empirical analysis are still associated with the EU-level groups they were associated with during our period of investigation, which covered the years 2008 to 2013 . $^{2}$ The interview data also confirm that it is common for national members to raise voice in the EU-level groups' decision-making bodies: $53 \%$ $(N=36$ of 68$)$ of the respondents stated that they had a seat on the executive board of the EU-level group, 52\% $(N=35$ of 67$)$ were represented in a political committee of the EU-level group that handled the EU policy proposal at hand, and $31 \%(N=21$ of 68$)$ were members of political delegations that presented the EU-level group's point of view on that proposal to the EU institutions. The institutional presence in EU-level groups is at least in part cumulative: 
board membership is positively associated with both committee work ${ }^{3}$ and the presence in a political delegation. ${ }^{4}$ The relevance of membership in an EU-level group - and of the presented default interest representation strategy - is reflected in the respondents' information exchanges: asked to indicate their 'most important source of information' on the policy proposal at hand, $31.4 \%(N=22$ of 70$)$ named an EU-level interest group, $25.7 \%(N=18)$ indicated their national government, and $17.1 \%(N=12)$ pointed to the European Commission. The remaining groups hinted at a variety of other sources. Asked to list the actor which they 'most frequently provided information to' on the proposal, 29.4\% ( $N=20$ of 68) named an EU-level interest group and another $29.4 \%$ indicated their national government. The answer shares for other recipients amounted to no more than $7.4 \%$ each.

In the following analysis, members' assessments of the EU-level interest groups' performance on two functions are the main independent variables: first, their capacity to retrieve, process, and submit relevant information on EU policies to their members as a major selective good, and secondly, their capacity to formulate common positions for their members as a major collective good. These two functions - information processing and formation of a common position - are considered to be the core functions of EU-level interest groups (Aspinwall and Greenwood 1998: 9-10). The information EU-level groups provide on incoming EU legislation can help members (1) to gauge the likely effects of the proposed directives, (2) to comprehend the strategic situation they are placed in, (3) to recognise 'that there is a common purpose' (Ahlquist and Levi 2011: 11) in the EU-level group, and may lead them (4) to reassess their preferences and positions. Recognition of a common purpose would reduce selective exit whereas the effects of the other three aspects are open in that respect.

The first explanatory variable measures the satisfaction of members with the information flow from the EU-level interest groups. Interviewees indicated their agreement with the statement that the EU-level group had delivered all relevant information on the legislative proposal to them (see Table 2) on a Likert scale: strongly disagree, disagree, neither agree nor disagree, agree, strongly agree. Most respondents found that EU-level interest groups had submitted all

Table 2. To what extent do you agree or disagree with the following statement about the information flow from the EU-level group [name]? The EU-level group [name] delivered all relevant information on this proposal to your organisation.

\begin{tabular}{lrc}
\hline Answer & $N$ & $\%$ \\
\hline Did not agree & 9 & 12.8 \\
Agree & 29 & 41.4 \\
Strongly agree & 32 & 45.7 \\
Total & 70 & 99.9 \\
\hline
\end{tabular}

Note: Own calculation based on INTEREURO project (http://www.intereuro.eu). Survey categories strongly disagree, disagree, and neither agree nor disagree grouped in one category (did not agree). 
relevant information. One member 'strongly disagreed' and another 'disagreed' with that statement. Seven respondents 'neither agreed nor disagreed'. Due to the small numbers in these three categories, Table 2 aggregates them in one category (did not agree). In contrast, 29 of 70 members 'agreed' that the EU associations had submitted all relevant information to them, and 32 'strongly agreed' with that statement. In sum, the EU-level groups' delivery of this selective good clearly meets members' expectations.

EU interest groups go a long way to incorporate their members' preferences when forming their common position. Beyond granting members a voice in their decision-making bodies, they have developed inclusive decision-making routines. Asked to verify if the EU-level group identified the common ground of its members' interests and presented that position to the EU institutions, $62 \%$ ( $N=43$ of 69$)$ of the respondents agreed or strongly agreed; $72 \%(N=49$ of 69$)$ agreed or strongly agreed that all members with a stake in the EU policy proposal had consented to the common position. By comparison, a smaller portion of members ( $43 \%$ or $N=30$ of 69 ) agreed or strongly agreed that the common position was defined by leading members of the EU-level group; $54 \%$ agreed or strongly agreed that the EU-level group' staff or leadership proactively defined the common position ( $N=37$ of 68). Hence, most members find that EU-level groups form consensual positions rather than top-down or oligarchic positions.

Nonetheless, given a heterogeneous, pan-European membership, for many EU-level groups it is impossible to satisfy all members' preferences. Furthermore, they must take heed of the EU institutions' demand for 'European encompassing interests' (Bouwen 2002) which may not always correspond with their members' preferences. The second explanatory variable indicates to what extent the common position formed in these groups corresponded with the initial preferences of the national members. The survey question had four categories. A little more than half of the respondents $(N=32$ of 60$)$ claimed that the common position was identical to their preferences; less than half $(N=26)$ indicated that the common position was 'close to' their preferences, while one respondent found it was 'a long way' from his organisation's initial preferences, and another indicated that it was the 'exact opposite. Table 3 summarises the last three answer categories in one category that covers all deviations from the common position. All in all, the common positions seem to vary only little from members' preferences. Nonetheless, almost half of the members had deviating preferences.

The dependent variables are three alternative strategies of interest representation (see Table 4). First, the national groups were asked whether they had entered into coalitions with other actors. Coalitions are issue-specific instruments that increase the information flow of actors and enable them to exert greater leverage on EU legislation by stating joint positions with other actors (Klüver 2012). In short, coalitions are formed to strengthen a 'policy side' in a policy debate (Baumgartner et al. 2009). As a selective exit strategy, they counteract 
Table 3. To what extent has the position that the EU-level group represented on this proposal been consistent with your organisation's initial preferences? Was the position identical to your initial preferences (1), close to, but not identical to your initial preferences (2), a long way from your initial preferences (3), or the exact opposite of your initial preferences (4)?

\begin{tabular}{lcc}
\hline Answer & $N$ & $\%$ \\
\hline The position was identical to your initial preferences & 32 & 53.3 \\
The position deviated from your initial preferences & 28 & 46.7 \\
Total & 60 & 100.0 \\
\hline
\end{tabular}

Note: Own calculation based on INTEREURO data (http://www.intereuro.eu). Categories 2 to 4 are summarised in one category for deviant preferences.

Table 4. How frequently did you participate in media debates and provide the following institutions with information to affect the legislative outcome? (National interest groups in percentages).

\begin{tabular}{lccccc}
\hline Frequency & $\begin{array}{c}\text { Participation } \\
\text { in media } \\
\text { debates }\end{array}$ & $\begin{array}{c}\text { European } \\
\text { Commission } \\
\text { leading DG }\end{array}$ & $\begin{array}{c}\text { EP } \\
\text { rapporteur }\end{array}$ & $\begin{array}{c}\text { Leading } \\
\text { national } \\
\text { department }\end{array}$ & $\begin{array}{c}\text { Members } \\
\text { of national } \\
\text { parliament }\end{array}$ \\
\hline Never & 24.3 & 53.5 & 50.7 & 5.6 & 54.3 \\
Rarely & 18.6 & 11.3 & 5.6 & 11.3 & 15.7 \\
Sometimes & 30.0 & 16.9 & 21.1 & 16.9 & 17.1 \\
Frequently & 21.4 & 14.1 & 15.5 & 33.8 & 8.6 \\
Very frequently & 5.7 & 4.2 & 7.0 & 32.4 & 4.3 \\
$N$ & 70 & 71 & 71 & 71 & 70 \\
\hline
\end{tabular}

Source: Own calculation based on INTEREURO project (http://www.intereuro.eu).

the representation of the EU-level group's common position and are a signal to limit the deviation from members' preferences. National members participate regularly in coalitions on EU legislation even though the majority of the respondents did not enter a coalition: 31 of 71 interviewees (43.7\%) indicated that their organisations had joined at least one coalition while 40 respondents answered that their organisations had not joined a coalition (56.3\%). Activities in coalitions are not significantly associated with members' institutionalised voice on EU-level groups' boards, committees, or delegations.

Secondly, we asked how frequently national groups voiced their positions in media debates. A media strategy is frequently regarded as an outside strategy by which interest groups seek to win the support of the public for their cause and draw the attention of decision-makers to certain problems and perspectives (Beyers 2004). As a selective exit strategy, media presence aims at winning the support of wider publics and decision-makers not just in favour of their own position but also against the stance of the EU-level group. Other than the formation of coalitions it does not require communication or coordinated action with like-minded actors. Interestingly, national groups participate more frequently in media debates on EU legislation than they supply information to the European Commission or the EP's rapporteurs. While one-quarter of the groups do not participate in media debates, $27 \%$ claim to engage frequently or 
very frequently in them. Members present on the EU-level groups executive boards, committees, or delegations do not engage significantly more (or less) frequently in media campaigns than other members.

Thirdly, the national groups stated how often they supplied information to EU institutions on the policy proposal at hand. To most national groups, the direct lobbying of the EU institutions is not a routine affair. Less than half of them submitted information to the leading Directorate General of the European Commission and the Rapporteur of the European Parliament, respectively. About three out of ten national actors were 'rarely' or 'sometimes' in contact with these institutions. Less than one-fifth submitted information 'frequently' or 'very frequently' to the Commission and slightly more than one-fifth to the EP, indicating the Parliament's increased weight in the EU's legislative process and its openness to domestic interests. Actors present in EU-level groups' boards and delegations are more frequently in touch with the EU-level institutions, suggesting a cumulative character of institutional representation and inside lobbying. ${ }^{5}$

Table 4 also provides evidence that national interest organisations routinely exchange information with national governments on EU policy-making: 94\% of them delivered information to the leading national department on the Commission's directive proposal; $11 \%$ of them did this rarely; and $17 \%$ did so sometimes. Almost two-thirds of the groups delivered such information frequently (34\%) or very frequently (32\%). Contacts with national parliaments are less common: not even half of the actors were in touch with national members of parliament.

Hence, the default strategy of national interest groups is to inform the leading national departments on their positions. Many national actors rely on their EU-level groups to represent their interests vis-à-vis the EU institutions, and those with a strong institutional presence in EU-level groups are also more vocal vis-à-vis the EU institutions. It is still uncommon for them to maintain a strong presence at both the national and the EU level. Only $18.3 \%(N=13$ of 71) of the national actors were frequently or very frequently in touch with both the leading national department and the leading Directorate General of the European Commission. These multilevel players tend to be major national peak associations such as Caritas Sweden, the Federal Association of Public Banks in Germany, the Investment Management Association or the Carbon Capture and Storage Association in the UK.

Finally, I include two common control variables in interest group studies: national modes of interest mediation and the types of interest group. A dummy variable for British associations probes whether the national modes of interest mediation matter to the strategic choices of national groups. Actors from corporatist settings may be more inclined to rely on their relations with national governments than actors from pluralistic settings such as the United Kingdom that would seek out a variety of venues to voice their demands. Moreover, 
different types of interest groups may have different strategic repertoires at their disposal. Diffuse interest groups are said to seek the support of the public through the media and elected politicians whereas specific interest groups are said to seek access to bureaucrats to whom they submit detailed technical information (e.g. Beyers 2004). I distinguish business interest associations as specific interests from both diffuse interests (for social, humanitarian, environmental interests, etc.) and other interests such as firms, professional groups, trade unions, institutions, research institutes, and regional authorities as the reference category because a wide variety of different actors was vocal on the studied directive proposals.

\section{The performance of EU-level interest groups and the selective exit of their members: exact logistic regressions}

How does the performance of EU-level interest organisations impact on the strategic choices of their members? When seeking to answer this question, the small sample size of 59 interest organisations in the subsequent analyses (due to the list-wise deletion of missing observations) requires some precautions. First, I employ exact logistic regressions with exact permutation methods to generate reliable statistical inferences (see Long 1997: 54). I also estimate logit regressions with bootstrapped standard errors (5000 replications) to check the robustness of relations among the experimental variables (see Appendix Tables A2 and A3). Second, the inspection of the data structure indicated correlations among the predictor variables in the following models below Pearson's $r=0.25$ and among predictor and outcome variables below $r=0.5$ which seems adequate (see Courvoisier et al. 2011). Furthermore, classic simulation studies claim that, in logistic regressions, 10 events are needed per predictor variable (EPV) (Peduzzi et al. 1996). In other words, for each explanatory variable, at least 10 observations are required in each category of the outcome variable. More recent simulations find that problems regarding confidence intervals and bias of estimates are 'not severe with 5-9 EPV' and 'usually comparable to those with 10-16 EPV' (Vittinghoff and McCulloch 2007: 717). To remain above the lower boundary of five EPV, the outcome categories of all presented ordinal variables were dichotomised with a 0 indicating no or rare usage and a 1 meaning usage or more frequent usage of a strategic option. Predictor variables were limited to the two experimental variables (information flow, congruence of positions) and two control variables (group type and mode of interest mediation). ${ }^{6}$

Table 5 presents the results of the regression analyses. The logit coefficients indicate the rate of change in the logged odds ratios to be in the higher (1) rather than the lower category ( 0 ) of the dependent variable if the independent variable increases by one unit. The corresponding odds ratios, standard errors, probabilities, and $95 \%$ confidence intervals are also presented. According to the model scores, the presumed selective exit options appear to be associated with the predictor variables. 


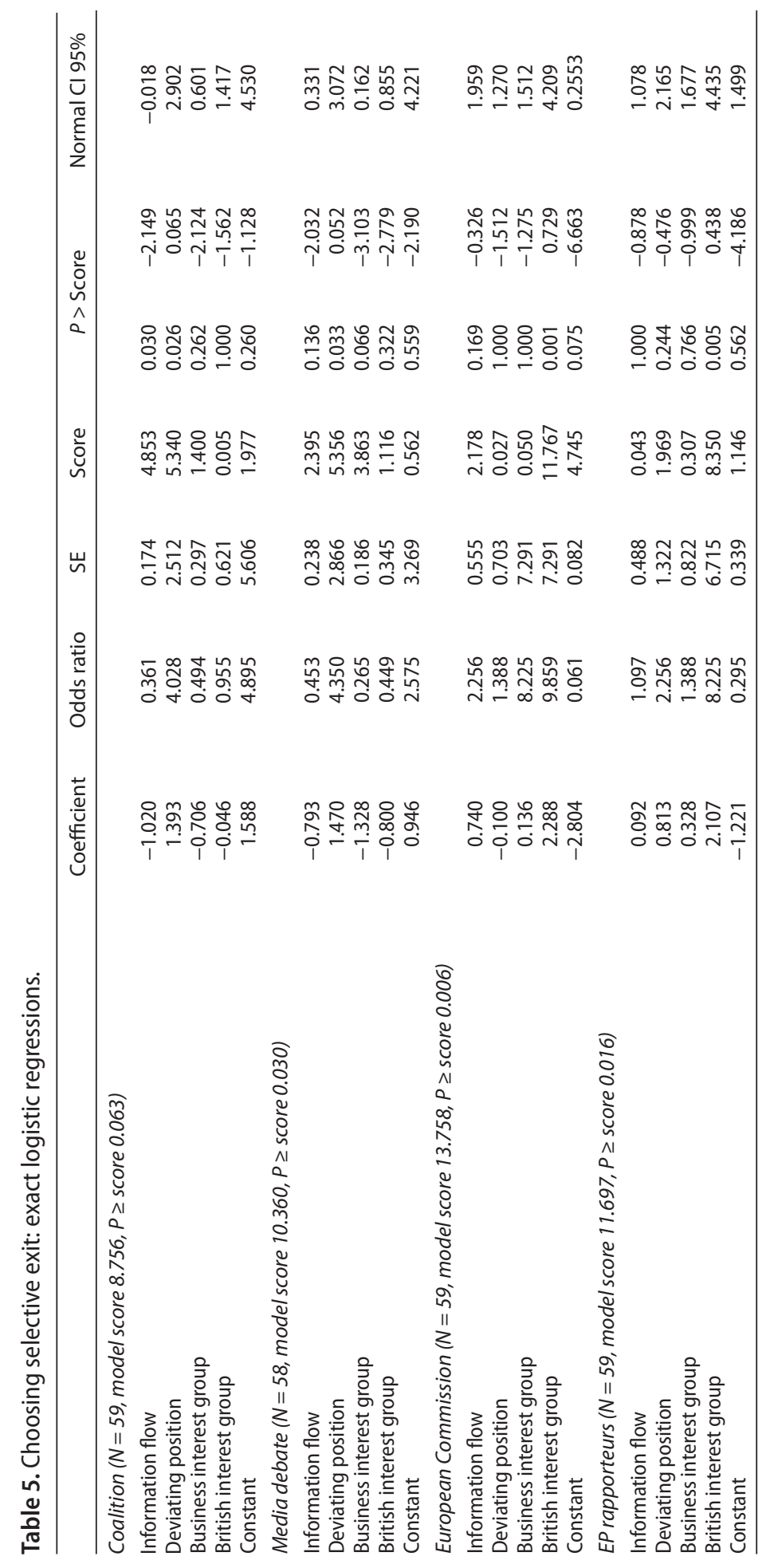


The following discussion concentrates on the impact of the information flow and the consistency of a member's preferences with the common position on this member's use of interest representation strategies outside the EU-level group. In correspondence with Hypothesis 1, the more discontented members are with the information flow from the EU-level group the more likely they are to join a coalition. The evidence on the other strategic choices is less supportive of Hypothesis 1: the information flow from EU-level groups does not impact on their members' submission of information to the EP rapporteurs, the European Commission or on their engagement in media debates. Apparently, issue-specific information deficits of EU-level groups do not lead national interest groups to cultivate or intensify relations with the EU institutions. ${ }^{7}$ In sum, Hypothesis 1 only finds empirical support with respect to members' participation in coalitions.

In accordance with Hypothesis 2, members whose preferences deviate from the EU-level group's common position are more likely to join a coalition than members whose preferences are consistent with it. On average, the odds of joining a coalition are four times higher for the former than for the latter. ${ }^{8}$ Figure 1 visualises major findings of the exact logistic regression. It illustrates the predicted marginal probability of non-business and non-British actors joining a coalition conditional upon the information flow and the consistency of their preferences with the EU-level groups' common positions. The upper, dashed line indicates the probability that members with deviating preferences will join a coalition. The lower, solid line illustrates the probability of members whose preferences are identical to the common position joining a coalition. The negative slopes of both curves suggest that a better information flow makes it less

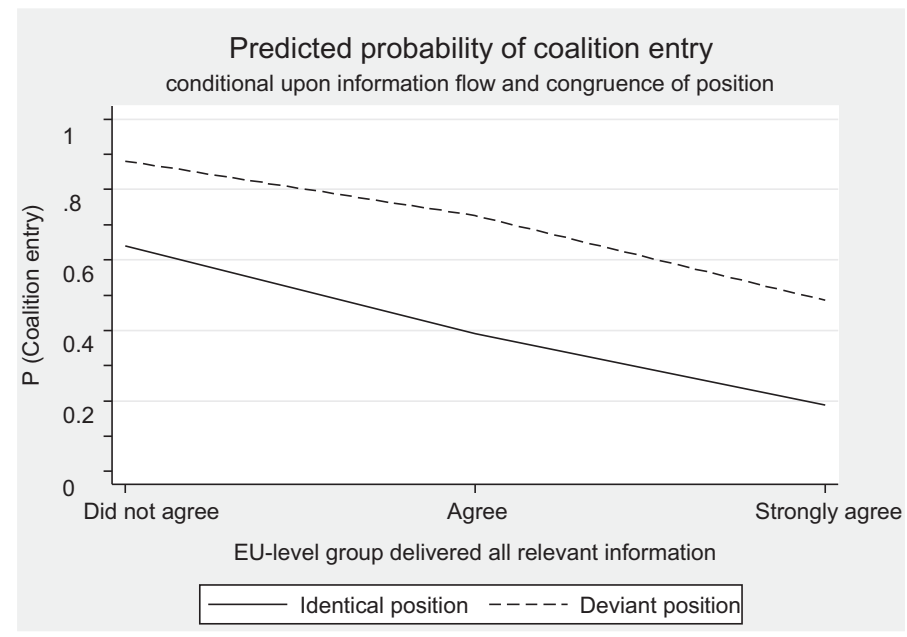

Figure 1. Predicted probability of coalition entry conditional upon information flow and consistence of preferences with EU-level group's common position. 
likely for members to join a coalition. Regardless of the positional congruence, the probability of joining a coalition drops by about 0.4 points from a rather poor information flow to a very good information flow.

According Figure 1, members with deviating positions are more likely to join a coalition than those whose preferences are identical to the EU-level group's position. If the former also perceive a poor information flow from the EU-level group they almost certainly join a coalition $(P=0.88)$ to counteract the EU-level group's activities. Coalition members signal to EU decision-makers that the EU-level group does not represent the interests of important segments of actors in its domain and indicate to the EU-level group's staff and other members that these cannot move the group's position to their preferred outcome without sincere opposition. The difference among members with deviant positions and members who share the EU-level group's position increases slightly when members 'agree' or 'strongly agree' that they obtained all relevant information from the EU-level organisation compared to a poor information flow. Two mechanisms may account for that effect: First, for members who side with the EU-level group's position, a poor information flow is a strong incentive to enter a coalition. Second, a better information flow from the EU-level group can increase the information of members with deviating positions in three respects. It can raise their awareness about the deviation of the common position from their preferences, ${ }^{9}$ increase their knowledge about the strategic context, and enhance the amount of information that is at their disposal in coalitions, turning them into more valuable coalition partners.

Members with deviating preferences also seek to contain the effects of the EU-level groups' positions on policy-makers through an increased media presence (Hypothesis 2), even though this finding is not sustained by the bootstrap regression that includes only the experimental variables. Moreover, business interest groups tend to be less present in the media than other types of actors, a pattern which corresponds well with their presumed recourse to inside rather than outside lobbying. An interim conclusion is that national members mobilise external support in response to incongruent positions by entering coalitions and alerting the public and policy-makers through media reports. In other words, they counter deficient collective goods and strengthen their 'policy side' (Baumgartner et al. 2009) by mobilising collective support for their positions.

In contrast to standard predictions in the literature, national groups' information exchange with EU-level institutions does not depend on the issuespecific performance of EU-level groups. More than half of the national actors forgo that option entirely (Table 4) and several groups resort to inside lobbying at EU level as a general complement to their lobbying at the national level and membership in EU-level groups. ${ }^{10}$ Yet others utilise it conditional upon factors not controlled for in this study (organisational resources, etc.). ${ }^{11}$ Finally, note that direct lobbying of EU institutions is associated with national patterns of interest mediation: as anticipated, pluralistic British groups are more frequently 
in touch with the EU institutions than corporatist Swedish, Dutch, German, or Slovenian actors.

\section{Conclusion}

Domestic interest organisations have several options to represent their positions in EU policy-making. Their ideal-typical interest representation strategy combines direct lobbying at national level with reliance on EU-level interest groups at the EU level. Stressing their membership in the EU-level groups, the article has augmented Hirschman's distinction of exit and voice as major responses to organisational performance failures. The study pointed out that EU-level interest groups have installed governance structures that grant their members a significant voice in their executive bodies, political committees and delegations as well as decision-making routines that aim at consensus formation rather than at top-down or oligarchic decisions. As a consequence, EU-level interest groups' common positions tend to be identical to or not far off their members' preferences.

It is very uncommon among national members to exit from EU-level interest groups in response to performance failures. I put forward the concept of selective exit to take the character of position papers as imperfect public goods as well as the divisibility of interest representation into account more than Hirschman's dichotomy does. Selective exit connotes members' use of interest representation strategies outside the EU-level groups in response to the performance gaps of these groups. Four potential selective exit strategies were suggested: coalition formation, media presence, lobbying the European Commission, and lobbying the European Parliament. In combination with raising voice within their boards, committees, and delegations, selective exit would enable members to address performance failures both from within and from outside EU-level interest organisations.

The empirical analysis identified two forms of selective exit. Members discontented with its information flow and members whose preferences differ from the common position formed in the EU-level group choose to join a coalition. The latter also show some tendency to participate in media debates to strengthen their 'policy side' (Baumgartner et al. 2009) in the EU's legislative debate. Countering the EU-level group's common position as an imperfect public good requires collective rather than individual action, which is why these members do not have increased recourse to the European Commission or the European Parliament. These rather specific strategic reactions to the performance gaps of the EU-level groups have gone unnoticed in previous studies on the strategies of national interest groups in EU policy-making. They were simply subsumed among all other channels of interest representation available in the EU multilevel system, no matter if used routinely or if conditional upon other factors. 
I conclude with a caveat and a research outlook: given the limited number of observations, findings should be verified in future studies with a wider empirical scope. Furthermore, the organisational leverage points that help EU associations contain and cope with selective exit merit attention. The preceding analysis pointed to: (1) the definition of their organisational domain, (2) the design of their governance and voice structures, (3) the combination of the goods and incentives EU-level groups supply, and (4) the extent of slack that selective exit may grant them.

\section{Notes}

1. According to Hirschman, the mobilisation of the public through media coverage is a form of voice. Here, I regard it as a variety of selective exit because it constitutes the usage of an alternative channel of interest articulation outside the boundaries of the EU-level interest group.

2. Of 59 national actors that are included in the subsequent analyses (or their successors in the case of name changes or mergers), 54 are today still associated with the EU-level associations (or their successors, respectively) they were associated with during our period of investigation. For three actors I could not find any information on their membership through national actors' websites, the websites of EU-level groups, or the Transparency Register (on 10 March 2017). Two actors had provided insufficient information on the name of the EU-level group they had joined to verify membership.

3. Pearson's $r=0.34[P=0.005], N=67$.

4. Pearson's $r=0.36[P=0.003], N=67$.

5. There are significant correlations between board membership and information provision to the Commission (Pearson's $r=0.35[P=0.003], N=68$ ) and the EP's rapporteurs (Pearson's $r=0.24[P=0.045], N=68$ ), between committee membership and information provision to EP's rapporteurs (Pearson's $r=0.35$ $[P=0.003], N=67)$, and between membership in a delegation and information provision to the Commission (Pearson's $r=0.28[P=0.020], N=68$ ).

6. Appendix Table A1 lists the definitions and descriptive statistics of the variables.

7. Neither a poor information flow nor a deviant position causes more frequent contacts with the national government or national members of parliament. Exact logistic regressions not reported.

8. The exact logistic regression model misses conventional significance levels even though the individual coefficients match them. The logit analysis utilising bootstrapped standard errors (Appendix Tables A2 and A3) suggests significant associations among the information flow and positional congruence, on the one hand, and the formation of coalitions on the other.

9. There is indeed a positive correlation between the information flow and the deviance of a member's position (Pearson's $r=0.260[P=0.047], N=68$ ).

10. Lobbying of the national government is positively associated with lobbying of the European Commission (Pearson's $r=0.388[P=0.001], N=71$ ), which in turn is positively associated with lobbying of the EP rapporteurs (Pearson's $\mathrm{r}=0.612[P=0.000], N=71)$. Actors lobbying the national MPs are more inclined to lobby the EP rapporteurs (Pearson's $r=0.292[P=0.014], N=70$ ).

11. Note that the salience of an issue to an interest group is not significantly correlated with its lobbying of EU and national institutions. 


\section{Acknowledgements}

I would like to thank the contributors to this special issue for their helpful comments. Moreover, I am grateful for the insightful suggestions of the anonymous reviewers.

\section{Disclosure statement}

No potential conflict of interest was reported by the author.

\section{Funding}

Research for this article was financed by the Deutsche Forschungsgemeinschaft [grant number EI 461/6-1] and the European Science Foundation project 10-ECRP-008: Comparative Research on Interest Group Politics in Europe (INTEREURO). The FritzThyssen-Foundation funded a workshop on multilevel interest representation that was held in preparation of this special issue at the Ruhr-University Bochum, 28-29 April 2016.

\section{References}

Ahlquist, John S., and Margaret Levi (2011). 'Leadership: What It Means, What It Does, and What We Want to Know about It', Annual Review of Political Science, 14, 1-24.

Aspinwall, Mark, and Justin Greenwood (1998). 'Conceptualising Collective Action in the European Union', in: Justin Greenwood and Mark Aspinwall (eds.), Collective Action in the European Union. Interests and the New Politics of Associability. London: Routledge, 1-30.

Baumgartner, Frank R., Jeffrey M. Berry, Marie Hojnacki, Beth L. Leech, and David C. Kimball (2009). Lobbying and Policy Change: Who Wins, Who Loses, and Why. Chicago, IL: University of Chicago Press.

Berkhout, Joost, Marcel Hanegraaff, and Caelesta Braun (2017). 'Is the EU Different? Comparing the Diversity of National and EU-Level Systems of Interest Organizations', West European Politics, doi: 10.1080/01402382.2017.1308695.

Beyers, Jan (2004). 'Voice and Access. Political Practices of European Interest Associations. 'European Union Politics 5:2, 211-240.

Beyers, Jan, Laura C. Bonafont, Andreas Dür, Rainer Eising, Danica Fink-Hafner, David Lowery, Christine Mahoney, and William Maloney (2014). 'The Intereuro Project: Logic and Structure', Interest Groups \& Advocacy, 3:2, 126-140.

Bouwen, Pieter (2002). 'Corporate Lobbying in the European Union: The Logic of Access', Journal of European Public Policy, 9:3, 365-390. 
Courvoisier, Delphine S., Christophe Combescure, Thomas Agoritsas, Angèle GayetAgeron, and Thomas V. Perneger (2011). 'Performance of Logistic Regression Modeling: Beyond the Number of Events per Variable, the Role of Data Structure', Journal of Clinical Epidemiology, 64:9, 993-1000.

Cowles, Maria G. (1997). 'Organizing Industrial Coalitions: A Challenge for the Future?', in Helen Wallace and Alasdair R. Young (eds.), Participation and Policy-Making in the European Union. Oxford: Clarendon Press, 116-140.

Dür, Andreas, and Gemma Mateo (2016). Insiders versus Outsiders. Interest Group Politics in Multi-Level Europe. Oxford: Oxford University Press.

Eising, Rainer (2009). The Political Economy of State-Business Relations in Europe. Interest Mediation, Capitalism and EU Policymaking. London: Routledge.

Eising, Rainer, Daniel Rasch, Patrycja Rozbicka, Daniela Fink-Hafner, Mitja HafnerFink, and Meta Novak (2017). 'Who Says What to Whom? Alignments and Arguments in EU Policy-Making', West European Politics, doi: 10.1080/01402382.2017.1320175.

Greenwood, Justin (2002). 'EU Interest Groups and Their Members: When is Membership a "Collective Action Problem”?', in Richard Balme, Didier Chabenet, and Vincent Wright (eds.), Laction Collective En Europe/Collective Action in Europe. Paris: Presses de Sciences Po, 227-253.

Greenwood, Justin (2003). Interest Representation in the European Union. Basingstoke: Palgrave McMillan.

Grote, Jürgen, Achim Lang, and Volker Schneider (2008). Organized Business Interests in Changing Environments: The Complexity of Adaptation. New York, NY: Palgrave.

Haas, Ernst B. (1958). The Uniting of Europe. Political, Social and Economic Forces, 1950-1957. Stanford: Stanford University Press.

Hirschman, Albert O. (1970). Exit, Voice, and Loyalty. Responses to Decline in Firms, Organizations, and States. Cambridge MA: Harvard University Press.

Jordan, Grant (1998). 'What Drives Associability at the European Level? The Limits of the Utalitarian Explanation', in Greenwood, Justin and Mark Aspinwall (eds.). Collective Action in the European Union. Interests and the New Politics of Associability. London: Routledge, 31-62.

Klüver, Heike (2012). 'Biasing Politics? Interest Group Participation in European PolicyMaking', West European Politics, 35:5, 1114-1133.

Kohler-Koch, Beate (1992). 'Interessen und Integration. Die Rolle organisierter Interessen im westeuropäischen Integrationsprozess', in Michael Kreile (ed.), Die Integration Europas (Politische Vierteljahresschrift Sonderheft 23). Opladen: Westdeutscher Verlag, 81-119.

Lijphart, Arendt (2012). Patterns of Democracy. Yale: Yale University Press, 2. ed.

Long, J. Scott (1997). Regression Models for Categorical and Limited Dependent Variables. Thousand Oaks, CA: Sage.

Lukšič, Igor (2012). 'Slowenien: Verbände und Interessengruppen', in Werner Reutter (ed.), Verbände und Interessengruppen in den Ländern der Europäischen Union. Wiesbaden: Springer VS, 2012, 699-721.

Mahoney, Christine, and Michael J. Beckstrand (2011). 'Following the Money: European Union Funding of Civil Society Organizations', Journal of Common Market Studies, 49:6, 1339-1361.

Olson, Mancur (1965). The Logic of Collective Action. Public Goods and the Theory of Goods. Cambridge: Harvard University Press.

Peduzzi, Peter N., John Concato, Elizabeth Kemper, Theodore R. Holford, and Alvan R. Feinstein (1996). 'A Simulation Study of the Number of Events per Variable in Logistic Regression Analysis', Journal of Clinical Epidemiology, 49:12, 1373-1379. 
Pollack, Mark (1997). 'Representing Diffuse Interests in EC Policy-Making', Journal of European Public Policy, 4:4, 572-590.

Richardson, Jeremy (2006). 'Organized Interests in the European Union', in Knud Jørgensen, Mark Pollack, and Ben J. Rosamond (eds.), The Sage Handbook of European Union Politics. London: Sage, 231-246.

Streeck, Wolfgang, and Philippe C. Schmitter (1994). 'From National Corporatism to Transnational Pluarlism: Organized Interests in the Single European Market', in Volker Eichener and Helmut Voelzkow (eds.), Europäische Integration und verbandliche Interessenvermittlung. Marburg: Metropolis, 181-216.

Traxler, Franz, and Philippe C. Schmitter (1994). 'Perspektiven europäischer Integration, verbandlicher Interessenvermittlung und Politikformulierung', in Volker Eichener and Helmut Voelzkow (eds.), Europäische Integration und verbandliche Interessenvermittlung. Marburg: Metropolis, 45-70.

Vittinghoff, Eric, and Charles E. McCulloch (2007). 'Relaxing the Rule of Ten Events per Variable in Logistic and Cox Regression', American Journal of Epidemiology, $165: 6,710-718$.

\section{Appendix}

Table A1. Definitions and descriptive statistics of variables $(N=59)$.

\begin{tabular}{|c|c|c|c|c|c|}
\hline Variable & Definition & Mean & $\mathrm{SD}$ & Min. & Max. \\
\hline $\begin{array}{l}\text { Media debates } \\
\quad(N=58)\end{array}$ & $\begin{array}{l}\text { Participation in media debates ( } 0=\text { never, rarely, } \\
\text { sometimes; } 1=\text { often, very often) }\end{array}$ & 0.31 & 0.47 & 0.00 & 1.00 \\
\hline $\begin{array}{l}\text { European } \\
\text { Commission }\end{array}$ & $\begin{array}{l}\text { Submission of information to leading DG of Europe- } \\
\text { an Commission ( } 0=\text { never, rarely; } 1=\text { sometimes, } \\
\text { often, very often) }\end{array}$ & 0.39 & 0.49 & 0.00 & 1.00 \\
\hline EP rapporteur & $\begin{array}{l}\text { Submission of information to EP rapporteur }(0= \\
\text { never, rarely; } 1=\text { sometimes, often, very often) }\end{array}$ & 0.49 & 0.50 & 0.00 & 1.00 \\
\hline Coalition & $\begin{array}{l}\text { Participation in coalition }(0=\text { not a member of a } \\
\text { coalition; } 1=\text { member of coalition) }\end{array}$ & 0.41 & 0.50 & 0.00 & 1.00 \\
\hline $\begin{array}{l}\text { Information } \\
\text { flow }\end{array}$ & $\begin{array}{l}\text { EU-level interest group delivered all relevant infor- } \\
\text { mation ( } 1=\text { neither agree nor disagree; } 2 \text { = agree; } \\
3=\text { agree strongly) }\end{array}$ & 2.36 & 0.66 & 1.00 & 3.00 \\
\hline $\begin{array}{l}\text { Deviating } \\
\text { position }\end{array}$ & $\begin{array}{l}0 \text { = identical position of a member with the EU-level } \\
\text { group's common position; } 1=\text { deviating position } \\
\text { of a member from the EU-level group's common } \\
\text { position }\end{array}$ & 0.48 & 0.50 & 0.00 & 1.00 \\
\hline $\begin{array}{l}\text { Business } \\
\text { interest } \\
\text { organisation }\end{array}$ & $\begin{array}{l}0=\text { diffuse and other interest groups; } 1=\text { business } \\
\text { interest organisation }\end{array}$ & 0.41 & 0.50 & 0.00 & 1.00 \\
\hline United Kingdom & $\begin{array}{l}0 \text { = Germany, Netherland, Slovenia, and Sweden; } \\
1 \text { = United Kingdom }\end{array}$ & 0.24 & 0.43 & 0.00 & 1.00 \\
\hline
\end{tabular}


Table A2. Logit regressions for experimental variables with bootstrapped standard errors.

\begin{tabular}{lrrrrrr}
\hline & Coefficient & Bootstrap SE & $\mathrm{Z}$ & $\mathrm{P}>|\mathrm{Z}|$ & Normal Cl 95\% \\
\hline European Commission & & & & & & \\
Information flow & 0.449 & 0.523 & 0.860 & 0.391 & -0.577 & 1.474 \\
Deviating position & 0.166 & 0.660 & 0.250 & 0.802 & -1.127 & 1.458 \\
Constant & -1.597 & 1.210 & -1.320 & 0.187 & -3.969 & 0.775 \\
EP rapporteurs & & & & & & \\
Information flow & -0.760 & 0.454 & -0.170 & 0.867 & -0.966 & 0.814 \\
Deviating position & 0.921 & 0.596 & 1.550 & 0.122 & -0.246 & 2.089 \\
Constant & -0.293 & 1.068 & -0.270 & 0.784 & -2.386 & 1.800 \\
Media debate & & & & & & \\
Information flow & -0.532 & 0.630 & -0.850 & 0.398 & -1.766 & 0.701 \\
Deviating position & 1.415 & 0.801 & 1.770 & 0.077 & -0.156 & 2.985 \\
Constant & -0.300 & 1.334 & -0.230 & 0.822 & -2.914 & 2.314 \\
Coalition & & & & & & \\
Information flow & -0.949 & 0.474 & -2.000 & 0.045 & -1.879 & -0.195 \\
Deviating position & 1.464 & 0.629 & 2.330 & 0.020 & 0.231 & 2.697 \\
Constant & 1.104 & 1.172 & 0.940 & 0.346 & -1.194 & 3.401 \\
\hline
\end{tabular}

Table A3. Attributes of bootstrap regressions.

\begin{tabular}{lcccc}
\hline & European Commission & EP rapporteurs & Media debate & Coalition \\
\hline$N$ & 59 & 59 & 58 & 59 \\
Replications & 5000 & 5000 & 4993 & 4999 \\
Wald X2 & 1.19 & 2.45 & 3.12 & 7.63 \\
$\mathrm{P}>\mathrm{X}^{2}$ & 0.553 & 0.294 & 0.210 & 0.022 \\
$\mathrm{LL}$ & -38.7417 & -39.434 & -33.147 & -35.807 \\
Pseudo R & 0.018 & 0.0355 & 0.077 & 0.102 \\
\hline
\end{tabular}




\title{
The multilevel interest representation of national business associations
}

\author{
Beate Kohler-Koch, Peter Kotzian and Christine Quittkat
}

\begin{abstract}
The role of interest groups in EU policy-making has been widely researched, but findings are still inconclusive. With regard to national business interest associations (BIAs), it is generally acknowledged that they have adopted a multilevel strategy in the course of EU integration. Yet there is little empirical knowledge as to how much attention they devote to national compared to EU institutions, how this varies between different levels of responsibility and which features of BIAs allow for access. Based on a large new dataset of BIAs from France, Germany, Poland and the United Kingdom, this article tests hypotheses derived from an exchange model of interest intermediation. The analysis shows that BIAs with high financial resources, BIAs with a high level of representativeness and multisectoral BIAs have the highest probability of access, whereas the economic importance of the represented sector has no relevance, not even for access to elected political actors, be they national or European.
\end{abstract}

This contribution puts the focus on the representation of national business interests in EU policy-making. It analyses the activities of national-level business interest associations (BIAs) among the range of potential advocates, as these are still the main interlocutors of $\mathrm{EU}$ and national institutions despite growing activities of individual firms and consultancies in EU lobbying (Bernhagen and Mitchell 2009; Coen 2009; Vannoni 2013).

While it is widely acknowledged that national-level BIAs pursue a multilevel strategy in EU lobbying, there is little empirical knowledge as to how much attention they devote to national compared to EU institutions and how their activities vary between different levels of responsibility, such as between the top level and the working level of an institution. To contribute to filling this 
gap, our study tackles the question of which factors foster access to policymaking institutions: are the associations' financial resources or rather the economic importance of the represented sector the prime predictor for access? How important are other, so far neglected, organisational properties, such as the size of the sectoral domain and the representativeness of the association?

In recent years, a number of research projects have looked more closely at the lobbying activities of national interest groups in the EU's multilevel system (for example Beyers and Kerremans 2012; Dür and Mateo 2016; Eising et al. 2017). The comparative analysis of BIAs, non-governmental organisations, professional organisations or trade unions has demonstrated the importance of group type in explaining associational behaviour, whereas results concerning the effect of differences in the endowment with material resources are still inconclusive, particularly in the light of the systematic correlations that exist between group type and availability of resources. By concentrating our analysis on one specific kind of interest group, employing a most similar cases research design and examining other organisational properties in addition to material resources, our findings will help to clarify and resolve this discussion.

We focus on the continuous efforts of BIAs to make institutional actors aware of business interests and therefore do not follow the recent trend in studying the factual influence of groups (Dür 2008; Dür and Mateo 2016; Dür et al. 2015; Klüver 2013; Lowery 2013). The reason for this is that presenting business interests in the EU is not just an ad hoc affair which starts when salient issues appear on the agenda, but an ongoing endeavour to establish social recognition and smooth working relations, all of which prepares the ground for exerting influence on a more consistent basis. Thus, BIAs do not only consider targeted contacts an important means of influencing specific EU policies but also find regular, personal contacts and the exchange of background information highly useful (Eising 2009: 133-4; Kohler-Koch and Quittkat 2016: 18). Accordingly, we are interested in access, which we define as contacts between national BIAs and public institutions, without qualifying these contacts - ranging from informal bilateral meetings to institutionalised multilateral consultations (Binderkrantz et al. 2016). Certainly, access does not imply influence (Bouwen 2004: 337). However, we contend that business still has a preference for insider strategies (Dür and Mateo 2016), assuming David Truman's dictum of 1951 that power cannot be reached without access (Truman 1951: 264) still to be valid today.

In this paper, we study the access of national BIAs to both EU and national target institutions in EU policy-making. Based on a comprehensive survey of BIAs from four countries, we use a multivariate analysis to test the explanatory value of different theory-based hypotheses. Specifically, we are interested to find out which characteristics of national BIAs or their members account for (preferential) access on a regular basis and which do not. Accordingly, we do 
not aim to maximise the explained variance in access. As to our theoretical approach, we start with a straightforward rational choice-based actor model and enrich it by understanding lobbying as an exchange relation. We modify Bouwen's (2004) well-known information-exchange model and introduce additional 'access goods' such as the representativeness of BIAs and the economic importance of the member companies. In methodological terms, we take greater care of sampling problems in interest group research than previous access studies by employing a selection model. The first part of the Heckman probit model analyses whether interest groups have access, and the second part studies how frequently they have access (in case they do). The results show that especially national BIAs address EU institutions almost as frequently as national institutions and that resources as well as representativeness increase the probability of access, whereas the economic importance of the represented sector has no relevance.

\section{Back to the roots: a parsimonious conceptual framework of BIA access}

According to a parsimonious rational choice approach, interest groups will concentrate their lobbying efforts on institutions that are decisive in the decision-making process and will expand their activities in accordance with available resources. With the deepening of the European integration, a multilevel system of governance emerged (Hooghe and Marks 2001), resulting in states 'losing their grip on the mediation of domestic interest representation in international relations' (Marks et al. 1996: 341). However, the multilevel governance (MLG) model does not preclude the importance of national institutions. Despite the continuous shift of competencies to the EU, national-level institutions still have a decisive say not just in the high politics of the EU but also in the low politics of economic regulation (Jordan 2001: 204; Marks et al. 1996: 346) and are relevant for implementing EU policies.

A more sophisticated approach identifies lobbying as an exchange relation. Pieter Bouwen has pointed out that business lobbying is not 'a unidirectional activity' (Bouwen 2004: 339) but depends on the decision-maker's interest in what BIAs have to offer. In his concept, it is an exchange relation in which information is traded for access (Bouwen 2002, 2004; Chalmers 2013). Bouwen attributes specific functional needs to EU institutions and explores the various access opportunities of European and national associations as well as of firms by distinguishing among three kinds of access goods: expert knowledge (offered by firms and consultancies), information about the European Encompassing Interest (offered by European associations) and information about the Domestic Encompassing Interest (offered by national associations) (Bouwen 2004: 340). Information is an access good, and the kind of information that is considered to be crucial is very much a matter of demand, as Arndt Wonka (2017) emphasises 
in his contribution to this special issue. Information, however, is not the only good decision-making institutions are interested in. Whether or not a BIA is a valid interlocutor also depends on its representativeness and its economic and political leverage. Therefore, we need to modify Bouwen's model by expanding the range of access goods. Unlike Wonka, we focus on the supply of access goods and consider the gatekeeper's role of lobbying addressees only indirectly (Binderkrantz et al. 2016).

As for the institutions, we put the focus on both the executive and the legislative institutions in the member states and in the EU. Taking into account differences in accessibility, we distinguish between the top decision-making level and the working level of the institutions (national government/administration: prime minister and ministers compared to permanent secretary and desk officers; European Commission: commissioners and cabinets compared to director-general and desk officers). Regarding the legislatures, we ask about contacts to the members and the committees of the national Houses of Parliament and the European Parliament. We did not include the European Council, the Council and the Permanent Representatives Committee (Comité des représentants permanents, COREPER), because interviews revealed that national BIAs usually do not contact them as collective EU institutions, but with the intention to target their national representatives.

Consistent with the characterisation of the EU as a multilevel system of governance, we suppose that BIAs pursue a multilevel lobbying strategy as described in the literature (Beyers 2002; Eising 2004). Even though many national BIAs are experienced in finding their way to the EU-level decision-makers and have adjusted to the rules of the game in the EU's multilevel system of governance, we side with Justin Greenwood's dictum that the 'national route represents the tried and tested ground' for interest representation (Greenwood 1997: 32). Furthermore, a rational consideration of lobbying options implies that efforts are affected by the likelihood of success, as it makes little sense to invest much effort in getting access to an actor who is unlikely to respond to these efforts (see also Eising et al. 2017; Wonka 2017), regardless of the importance this actor may have for the decision process. Given the EU institutions' preference for dealing with EU-level associations and the great competition for influence at EU level, the embeddedness of national associations in the domestic political systems makes it likely that national BIAs find it easier to contact 'their' national decision-makers rather than European decision-makers:

Hypothesis 1: National BIAs are multilevel players but have more frequent contacts with national institutions than with EU institutions.

Lobbying in the EU's multilevel system incurs far higher transaction costs than lobbying in the national arena. The complexity of EU decision-making requires an additional effort, and it is far costlier to organise events in Brussels than at home. Thus, the need for material resources is felt most strongly when national BIAs engage in direct EU lobbying. Several authors have already put 
the analysis of the impact of resources centre stage (Beyers and Kerremans 2012; Dür 2008: 1214; Dür and Mateo 2016; Eising 2004, 2007, 2009; and critically Beyers 2008). We expand the argument by claiming that the endownment with financial means is more crucial when national BIAs seek to address EU rather than national institutions.

Hypothesis 2(a): The greater a BIA's financial resources, the better access it has to political institutions in general.

Hypothesis 2(b): The relevance of financial resources is greater for access to EU institutions than for access to national institutions.

An influential factor often mentioned in EU interest group studies (e.g. Saurugger 2008) but rarely empirically examined (for an exception, see Klüver 2010, 2012) is legitimacy based on representativeness. Bouwen (2002: 370) suggests that 'The density of the interest group's membership is the basis for its recognition by the public authorities as a legitimate interlocutor. We argue that representativeness in terms of membership density is an access good for two reasons: first, the greater the representativeness of an association, the more encompassing is its view of the constituent business community. Second, the greater an association's membership density, the more capable it is of campaigning for a wide acceptance of the regulatory output if participation in policy-making was previously granted to it. As decision-makers tend to be interested in minimising or at least reducing opposition to bills and their implementation, being able to speak for many or all individual stakeholders increases the attractiveness as a partner in a political deal. Thus, both EU and national institutions will more readily listen to associations which represent all relevant stakeholders and can point to a high degree of organisation (see also Berkhout et al. 2017). As representation is also a highly valued democratic principle, we expect elected political actors to be more susceptible to an association's representativeness than bureaucrats at the working level.

Hypothesis 3(a): The greater the representativeness of a BIA, the more frequently it obtains access.

Hypothesis 3(b): Representativeness is more relevant for access to parliament and to the executive's top level than for access to the executive's working level.

A similar logic applies to the political importance of BIAs. Apart from the economic clout of business, which is said to make state actors receptive to the voice of business (Offe and Wiesenthal 1980: 80-86), BIAs may also be relevant in electoral terms. Associations representing a large share of the workforce should find it easier to gain access to decision-makers because their member firms' employees are voters. The receptiveness of politicians to BIA's demands may therefore translate into favourable voting behaviour. Consequently, responsiveness should be highest among elected national politicians, such as the toplevel actors of government and the members of parliament, and far lower for the EU Commission, especially at the working level. 
Hypothesis 4: The larger the workforce represented by an association, the higher the frequency of contacts with elected political actors.

Our study focuses on the supply side of 'information as an exchange good'. We expect that the capacity to offer information varies with the sectoral scope of national BIAs. We distinguish between three categories of sectoral scope: first, associations representing more than one industrial or service sector (e.g. mechanical engineering and metal working) or industry in general, as is the case for industry confederations and federations such as the Confederation of British Industry (CBI), Mouvement des entreprises de France (MEDEF), Bundesverband der Deutschen Industrie (BDI) and Polska Konfederacja Pracodawców Prywatnych Lewiatan (PKPP Lewiatan); second, associations representing just one sector (e.g. mechanical engineering); third, associations representing a (specialised) subsector (e.g. robotics).

Unlike previous studies that distinguish technical and political information (e.g. Dür et al. 2015), we separate technical information from broader economic information. We argue that small and highly specialised subsector associations provide high-quality, most often technical, expert knowledge. In contrast, multisector associations monitor the general industrial policy framework and dispose of information on a range of sectors or on the entire domestic industry. In between these two are the sector associations which have both expert knowledge and information about the implications of EU regulations at the meso level of sectors (see Table 1).

With respect to the members of national parliaments, Wonka (2017) argues that interest groups are far from being the only information sources these public actors can access. Based on a systematic study of German industry associations (Kohler-Koch forthcoming), we contend that BIAs are the most important information brokers in many policy processes. Especially information containing technical knowledge is a rather exclusive good that is provided by experts based more often in companies than in public research institutions. Subsector associations know in which member firms the experts are located and connect them to the public actors. Sector associations do the same but refer to a wider range of expert knowledge, whereas multisector BIAs usually do not offer technical expert knowledge but rather information about the broader economic effects of a policy. Furthermore, representing a very large part of the economy, they have more issues on their agenda and need to be present in more decision-making processes than sectoral or subsectoral associations.

Table 1. Command of different types of information by national bias.

\begin{tabular}{lcc}
\hline & Technical information & Information on larger economic effects \\
\hline Subsector BIAs & $\mathrm{X}$ & $\mathrm{X}$ \\
Sector BIAs & $\mathrm{X}$ & $\mathrm{X}$ \\
Multisector BIAs & & \\
\hline
\end{tabular}


Hypothesis 5(a): Multisector BIAs have better access to national and EU institutions than the other types of associations because they act for a broader range of interests.

However, there is also a counter-argument leading to a competing hypothesis. It is based on the assumption that contacts with the top level are of a more general political nature, whereas contacts to the working level concern primarily technical issues. In arenas in which the details of legislation, requiring particular technical expertise, are drafted, the aggregation of interests by multisector BIAs is likely to count for less. On the other hand, associations with a smaller sectoral scope, being closer to the practice, can provide more detailed (technical) information. Thus, sectoral and subsectoral associations might be able to have at least as frequent access as multisectoral associations to the working level of the Commission and the national governments as well as to the committees of the EP and the national parliaments.

Hypothesis 5(b): Multisector BIAs do not have more frequent access to the work-

ing level of the EU and national institutions than sectoral or subsectoral BIAs.

\section{Research design and operationalisation}

As we are interested in testing hypotheses about which properties of BIAs enable them to get access to political institutions, we collected empirical information on the BIAs' access to institutions at both the national and European level as well as on their endownment with the resources that are relevant according to our theoretical arguments. We sampled BIAs from four countries to control for the effects of national modes of interest representation and on having long- or short-term experience in dealing with the EU. In terms of interest representation, Germany is generally classified as a neo-corporatist country, the United Kingdom as a pluralist one, and France as a statist one, where the state dominates in interest intermediation (Beyers and Kerremans 2012, Schmidt 2006). Poland is characterised as a system of 'fragmented representation of interests' (Jasiecki 2014) which shows similarity to neither the corporatist nor pluralist model. The first three countries have been EU members for a long time. Newcomer Poland, which joined the EU during the Eastern enlargement, was selected for the cross-national comparison because it comes closer to the three 'old' member states in terms of economic size than any other new EU member state. Since we included four distinct variations of state-interest group relations, our findings regarding the relevance of institutions' and BIAs' organisational properties should be representative for national BIAs from a large variety of different countries.

In each of the four countries, we gathered information on the national population of BIAs by using the main directories of interest groups and collecting expert advice. ${ }^{1}$ In addition, we screened the internet for missing or unclear 
information. We did not exclude national BIAs without EU-level contacts in order to be able to draw inferences for the entire population of nationwide BIAs. However, many associations listed in the directories turned out to exist only on paper or not to fit our definition of a BIA: i.e. a voluntary not-for-profit association with private business firms and/or other business associations as members and committed to the common interests of its members. We excluded the craft sector and associations representing only employer interests or professional interests as well as organisations geared towards research promotion, education, or which are only active at the subnational or local level. However, we included BIAs with a dual function, operating also as employer associations, as is often the case in France (Quittkat 2006). The survey was conducted in several steps between 2012 and 2015. We addressed 1515 national BIAs in total; the final response rate came to $29.5 \%$ (447 participants), which is in line with response rates obtained in similar research projects (Marchetti 2015: 276). The response rates vary among the countries, amounting to $23 \%$ in the UK and France and to about $37 \%$ in Germany and Poland (see the Appendix 1).

The sample is representative of the national BIA populations in so far as its composition, measured by the size of BIAs, corresponds to general descriptions in the literature (Reutter 2012, Traxler and Huemer 2007). The very small BIAs with up to five full-time employees prevail in each of our country samples; their number is especially large in Poland (56.0\%) and France (44.6\%), and amounts to about a third of the sample in the UK (33.0\%) and Germany (32.2\%). This closely corresponds to other studies (see, for example, Bernhagen, 2013: 7; Dür and Mateo 2016). The share of mid-sized BIAs with 6-25 full-time employees is higher in the UK (48\%) and Germany (46.3\%) than in France (35.9\%) and Poland (34.0\%). Regarding large BIAs with more than 25 full-time employees, their share in Germany (17.6\%) lies above their shares in the UK and France (both $13.0 \%$ ), whereas in Poland they represent only a minority (2.0\%).

Despite the representativeness of the sample in several regards, it should be noted that there probably is some self-selection bias in our sample although we did not exclude national BIAs without EU-level contacts. It is plausible that BIAs which do not have any contact with the EU are less likely to participate in the survey. To get an estimate of the magnitude of this problem, we drew a random sample of BIAs that did not reply to the survey and asked for their reasons. The main reason given by the 138 respondents was a lack of resources (44.9\%), but many (37.7\%) also declared that they have no lobbying activities which aim directly at the EU institutions. Both statements are highly correlated, which made us wonder whether the lack of contact is decisive for not participating and thus for being under-represented in our survey. However, a comparison of the non-respondents' answers with our survey data indicates that our sample does not differ fundamentally from the non-respondents in terms of having contact. In our survey, the share of BIAs reporting no contacts with EU institutions ranges from 55\% in the case of the EU top level to about 33\% 
in the case of the other EU institutions; this compares to the percentages found among the non-respondents. Still, the analysis of the non-responses hints at a potential problem, which is taken into account by our statistical analysis. While we have no data to model the selection process itself - i.e. to explain who did participate in the survey and who did not - we use a Heckman procedure (see below) to differentiate between explaining if a BIA has contacts and if it has, what drives the frequency of its contacts.

In terms of the following statistical analysis, the survey provides us with unique data concerning properties of BIAs and their access to national and $\mathrm{EU}$ institutions. The dependent variable, the BIAs' access to institutions in the context of EU law-making, was measured by asking respondents about the frequency of their organisations' contacts with European and national political institutions. We include financial resources, representativeness, the size of the association's domain (scope) and the number of employees in the BIAs' member companies in the analysis. In addition, we control for the concentration of the represented economic sector, i.e. the share of turnover generated by the three largest members in the BIA. If the sector is dominated by a small number of large actors, we expect the collective action problem to be less pertinent. Given that the employed statistical procedure requires that the selection model, which explains whether or not BIAs have any contact, has more explanatory variables than the model that explains how many contacts they have, we omitted this variable from the latter.

\section{Empirical findings}

We proceed in three steps. We begin with a brief descriptive presentation of our data to give insight into the multilevel character of EU lobbying. We explore the contacts of BIAs with national institutions compared to EU institutions. The main part of our empirical analysis is based on a multivariate ordinal regression analysis that tests our hypotheses about the factors affecting access of national BIAs in the EU.

\section{The general pattern: multilevel lobbying}

Regarding the first hypothesis, our data indicate that interest representation in EU affairs is a multilevel lobbying endeavour for national BIAs. Two-thirds of our respondents $(66.0 \%, N=295)$ indicated that they pursue a multilevel strategy by means of forging contacts to both institutional levels, which confirms our previous findings (Eising 2009, 2004; Kohler-Koch and Quittkat 1999; Quittkat 2006) and the predominant view in the literature (Beyers and Kerremans 2012; Pappi and Henning 1999). This is a very high figure, especially when compared to other types of organisations (Klüver 2010) and to BIAs from other EU member countries and accession countries (Cekik 2017; Dür and Mateo 2016). Still, 
a relevant number of the national BIAs among our respondents $(5.15 \%, N=23)$ do not engage in EU lobbying at all, at EU level or at national level.

The vast majority of national BIAs (73.2\%) state that they have at least some contact with EU institutions with only minor variations across countries (UK $64.0 \%$, Poland 70.0\%, France $73.9 \%$, Germany 78.1\%). The share of BIAs having at least some contact with national institutions in the context of EU interest intermediation is higher, amounting to $87.7 \%$. We also find a considerable difference between the French BIAs (75.0\%) and the BIAs from the other three countries (Germany 89.8\%; UK 91.0\%; Poland 96.0\%). Comparing the mean access at the EU level with that at the national level confirms that national BIAs tend to have significantly more contacts at the national level than at the EU level ( $t$-test, $\mathrm{df}=447, t=-4.31$ ), which is clear support for hypothesis 1 . When studying each country individually, only in the case of France is the difference between the mean contacts to national and EU institutions not significant.

\section{Explaining difference in access: a multivariate analysis}

In the theoretical discussion, we singled out the factors that are most likely to affect BIA access. We study the relationship between these factors and the access to the institutions in charge of the majority of EU policy-making, as measured by the frequency of contacts with these national and EU institutions. Given the sample-selection problem mentioned above, we choose a two-stage Heckman ordinal probit model. First, we analyse whether a BIA has access at all (selection model). Second, provided it does, we analyse the factors impacting on the frequency of access. We do so by means of an ordered probit model, as the contact frequency with the national and EU institutions is ordered in six different frequency categories $(1=$ no contact; $2=$ yearly, $3=$ half-yearly, $4=$ quarterly, $5=$ monthly, and $6=$ weekly contact). As for interpreting the results, positive coefficients in the selection model (upper part of Table 2) indicate a higher likelihood of having any contact, and positive coefficients in the ordinal probit model (lower part of Table 2) indicate a higher frequency of contacts. Brant tests confirm that the underlying proportional odds assumption of ordered logit regression analysis holds; furthermore, the relationships between the explanatory variables and the dependent variables are approximately linear with no structural breaks, which can be illustrated by using a smoother line.

The explanatory variables are budget, level of representativeness, size of workforce, member dominance (defined by the market share of the three largest members of the BIA) and the sectoral scope of a BIA. Budget, representativeness, member dominance and workforce are all measured as ordinal variables. Three categories are used for the variable sectoral scope. The category with the lowest scope ('subsector') serves as the reference category. The national origin of the BIA was included using dummy variables that indicate the origin, with the UK serving as the reference category. See Table 3 for the descriptive statistics. 


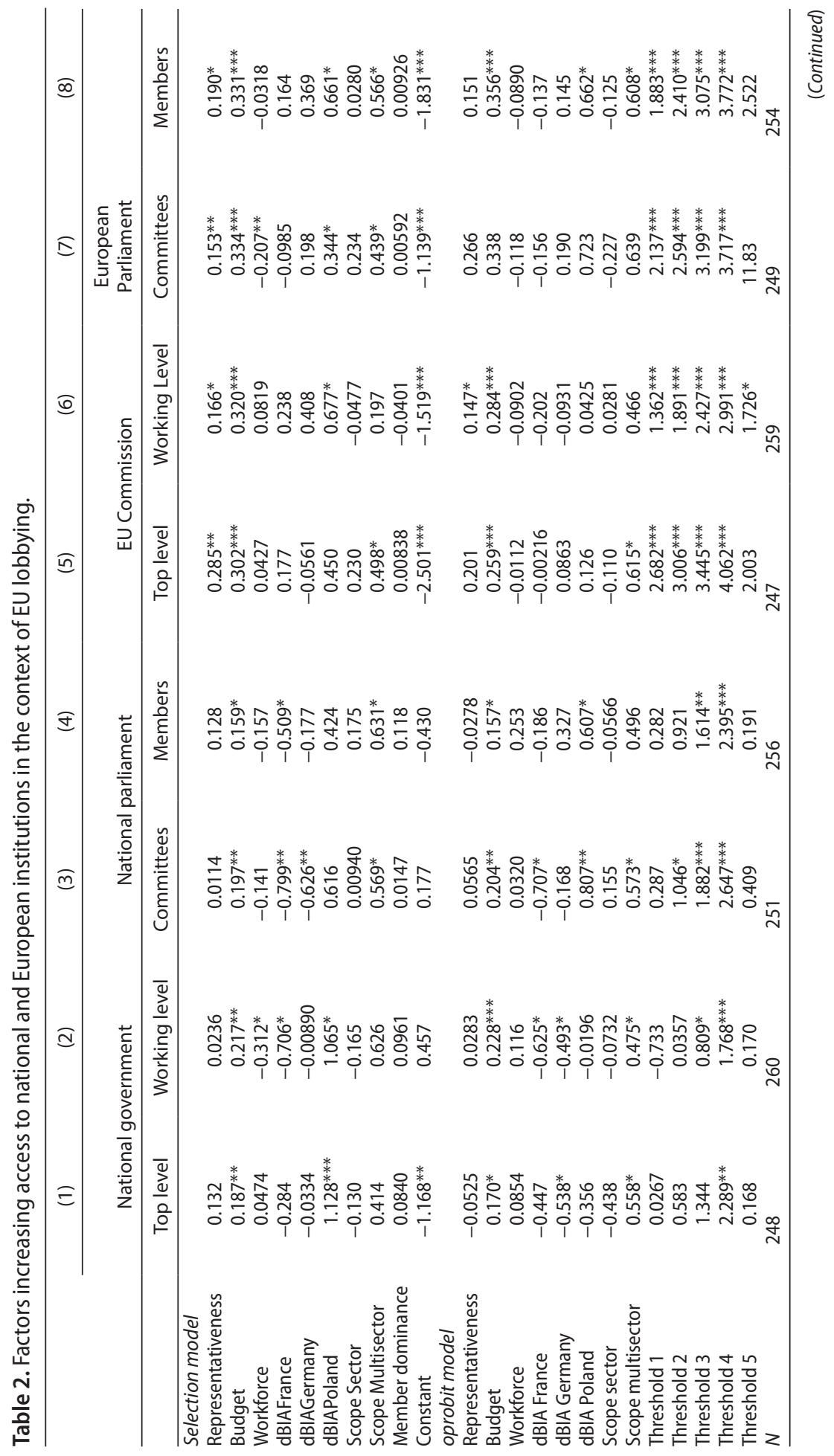




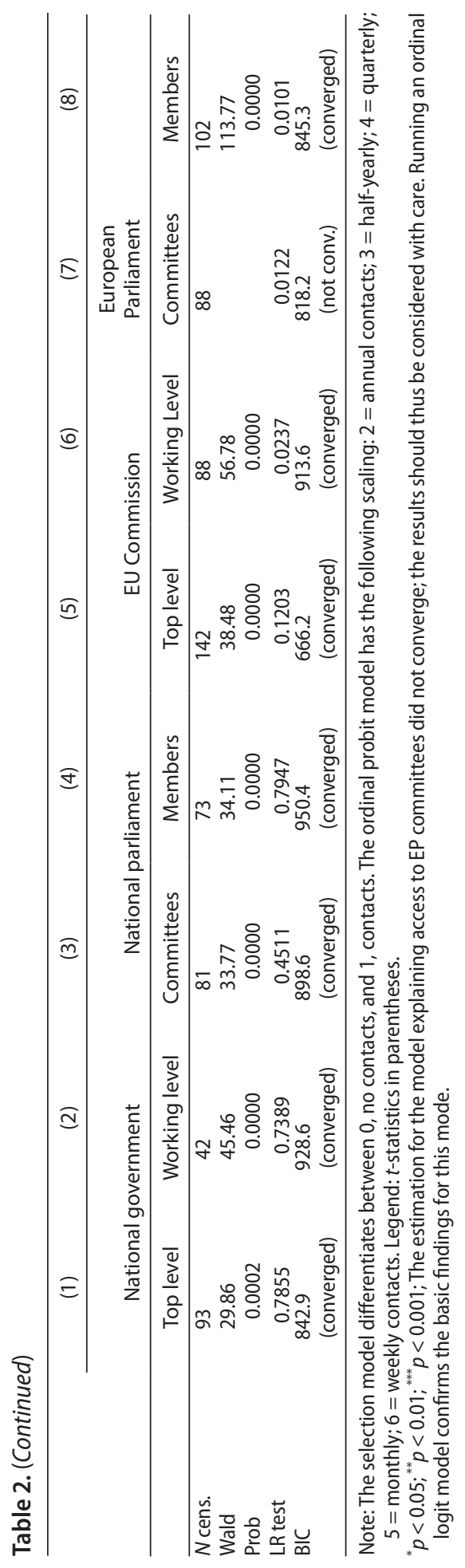


Table 3. Descriptives of dependent and explanatory variables.

\begin{tabular}{llllll}
\hline Variable & Obs & Mean & Std. Dev. & Min & Max \\
\hline Access EU institutions & 423 & 1.921986 & 1.304772 & 1 & 6 \\
EU Commission top level & 441 & 2.868481 & 1.697841 & 1 & 6 \\
EU Commission working level & 421 & 2.926366 & 1.794646 & 1 & 6 \\
EP committees & 434 & 2.778802 & 1.710425 & 1 & 6 \\
EP members & & & & & \\
Access national institutions & 422 & 2.511848 & 1.485832 & 1 & 6 \\
National government top level & 441 & 3.873016 & 1.676637 & 1 & 6 \\
National government working level & 434 & 3.156682 & 1.721583 & 1 & 6 \\
National parliament members & 425 & 2.856471 & 1.639895 & 1 & 6 \\
National parliament committees & & & & & \\
Explanatory variables & 406 & 3.142857 & 1.022843 & 1 & 4 \\
Representativeness & 377 & 3.647215 & 1.801359 & 1 & 7 \\
Budget & 401 & 1.543641 & 0.8992862 & 1 & 4 \\
Workforce & 322 & 2.751553 & 0.9733589 & 1 & 5 \\
Member dominance & 447 & 0.2058166 & 0.40475 & 0 & 1 \\
dBIAFrance & 447 & 0.458613 & 0.4988425 & 0 & 1 \\
dBIAGermany & 447 & 0.1118568 & 0.3155434 & 0 & 1 \\
dBIAPoland & 441 & 0.122449 & 0.3281759 & 0 & 1 \\
Scope sector & 441 & 0.1814059 & 0.3857918 & 0 & 1 \\
Scope multisector & & & & \\
\hline Notes: Coding of access variables: & cont; & & & & \\
\end{tabular}

Notes: Coding of access variables: 1 = no contact; 2 =yearly; $3=$ half-yearly; 4 = quarterly; $5=$ monthly; $6=$ weekly. Coding of representativeness: $1=1-25 \% ; 2=26-50 \% ; 3=51-75 \% ; 4=76-100 \%$. Coding of budget: $1=$ up to 100,$000 ; 2=$ up to 250,$000 ; 3=$ up to 500,$000 ; 4=$ up to 1 million; $5=$ up to 3 million; $6=$ up to 5 million; $7=$ more than 5 million. Coding of workforce: $1=$ up to 100,$000 ; 2=$ up to 500,000 ; up to 1 million; $4=$ more than 1 million. Coding of member dominance: $1=0 \% ; 2=1-25 \% ; 3=26-50 \%$; $4=51-75 \% ; 5=76-100 \%)$.

Table 2 presents the results of the ordered probit model with sample selection (heckoprobit). All models indicate significant associations between predictors and dependent variables (see the rows 'Wald' and 'Prob', giving the Waldstatistic and its significance, respectively). The 'LR test' towards the bottom of Table 2 indicates the probability of the null-hypothesis, i.e. that sample-selection problems are irrelevant. We find that using just an ordered probit model would indeed be inappropriate in the case of the EU institutions: if not taken into account, the sample-selection problem would have biased the results; there is no such problem in the case of the national-level institutions. Heckman models require that the selection model (is there access at all?) has at least one more variable than the set used in the ordered probit part of the model (if there is access, how often?); thus, member dominance was omitted in the latter.

Looking at the findings with regard to the hypotheses, we see that the results confirm some but not all of our hypotheses.

In line with Hypothesis 2(a), the endowment with financial resources has a very strong positive influence on access to all institutions. Furthermore, financial resources are more relevant for obtaining access to EU institutions and less for obtaining access to institutions in the member states, a pattern we assumed in hypothesis 2 (b). ${ }^{2}$ Disposing of a higher budget significantly increases the probability of having access to the EU institutions for national BIAs, and in 
this case a higher budget significantly increases the probability of high contact frequencies.

When we examine access to national institutions, the budget of national BIAs is basically the only relevant feature for establishing contacts with the top level of the government and the bureaucrats at the working level, and it is also important for contacts to parliamentary committees. By comparison, getting access to members of the national parliaments is not only dependent on the BIA's budget but also on their sectoral scope. Unlike other factors, budget is a significant predictor in almost all models (with the notable exception of Model 7 estimating the number of contacts with EP committees) and there are no diminishing returns. Nevertheless, it might not be the most crucial resource, as we will see in the following.

We suggested the representativeness of a BIA to be also a relevant access good, but expected a differentiated effect: it should be more relevant for having contacts with elected political actors, namely members of parliaments and the top level of the executive institutions at the national and the EU level than for having contact with the working-level bureaucrats. First of all, our findings indicate a clear division between the national and the European level. The representativeness of BIAs is indeed highly important for having access to the EU level at all, as postulated in hypothesis 3(a). But the assumption does not hold for the national level; here, representativeness is relevant neither for having access nor for the frequency of contacts, once access is granted.

Looking at hypothesis 3(b), we see that a BIA's representativeness is still of some relevance once it is a member of the 'club' of those with access to the EU institutions. The coefficients are large, albeit mostly insignificant and therefore irrelevant for explaining differences in the degrees of access. However, one interesting finding stands out: among the national BIAs that have access, being representative is highly relevant for the frequency of access to the Commission's working level. Since, as argued above, the working level is a crucial access point for influencing policy in the making, representativeness is a resource of a highly specific utility: it determines access to the circles that are most relevant to the preparation of EU policy proposals and the implementation of EU policies.

Surprisingly, the size of the member firms' workforce seems to have little effect on the access of BIAs to political institutions. We expected BIAs representing firms with a large workforce to have more frequent contacts with elected politicians (hypothesis 4 ) but find no support for this in our data. On the contrary, there are negative effects for the national government's working level and for the EP's committees. This absence of a positive effect is surprising, especially for national institutions, and here in particular for national MPs, since it could be assumed that there was a link between regionally concentrated industries and MPs directly elected on a district basis. Still, the data do not support the argument.

Regarding the sectoral scope of BIAs and their ability to deliver different kinds of information and to speak for a varying range of interests, the results 
basically confirm hypothesis 5(a): multisector BIAs have more access to national and EU institutions than small-scale BIAs. The presumed effect is present and strong, albeit it does not always reach statistical significance. For reasons of clarity, we may emphasise that representativeness in terms of membership density and sectoral scope are conceptually and statistically independent notions. As we see no substantial differences in the relevance of the scope variable between the institutional top level, which is presumably interested in general information, and the working level, which is presumably interested in specific and technical information, we have to reject hypothesis 5 (b).

Finally, we observe the persistence of some established findings when looking at the effects of the BIAs' national origin and controlling for organisational properties, but there are also findings that contradict other surveys. French BIAs still have less access to national-level institutions than British BIAs, the reference category, suggesting that the statist model persists at the national level. At the European level, however, access of BIAs from the 'old' member states does not differ. Interestingly, the BIAs from newcomer Poland are much more active than those of the old members in our survey. This finding is contradictory to the outcomes of another comparative research project that includes Slovenia as a newcomer (see Hafner-Fink et al. 2016).

\section{Conclusion}

One way to demonstrate the working of EU multilevel governance is to analyse patterns of interest representation. BIAs are a worthwhile object to study because of their widespread presence in EU lobbying. We examined business lobbying as the continuous effort of BIAs to make decision-makers at $\mathrm{EU}$ and national level aware of their members' interests in the context of EU law-making. By analysing the access of national BIAs, defined as contacts to public institutions, we gained insights which partly confirm and partly refute established knowledge.

National BIAs are of particular interest due to their embeddedness in their home countries and because, as a matter of principle, EU institutions assign them only a secondary role compared to EU-level associations. Both factors might induce them to focus on their home turf. Yet, we found most national BIAs to be active players in EU lobbying and, with few exceptions, to target both national and $\mathrm{EU}$ institutions. The national route of interest intermediation is clearly visible and, although the large majority of national BIAs are multilevel players, they more frequently turn to their national government, addressing first and foremost the relevant desk officer in the administration. National differences in EU lobbying persist, and access patterns of BIAs from old member states fit well into national traditions of interest representation, whereas our research findings on Polish interest groups is not in line with survey results from other new member states. 
Turning to the factors facilitating access, conventional wisdom has it that resource endowment, in particular financial resources, is a key factor for active advocacy. Our results fully support this: budget is a universal resource in relation to all addressees and at all stages of the process. However, we gain a far more differentiated and realistic assessment by conceptualising EU lobbying as an exchange relation. BIAs vary in their capacity to deliver what political institutions are looking for.

Information is an important access good in public consultations and the core of Bouwen's original exchange model. Economic governance is a matter of regulation, built both on detailed technical expertise and wider socio-economic knowledge. The more information BIAs have to offer, the easier they will find access to decision-makers. We proposed that the range and type of information varies with the scope of the association and that this will affect which actor grants access. The more encompassing the domain of an association, the more likely it can provide general information on economic policy effects and aggregate views of a large part of the business world. Associations representing a specific sector or subsector of the economy are less able to do so, but they can excel in specialised technical knowledge. The data confirm the hypothesis of an overall presence of multisector associations and thus (implicitly) also the relevance of information on policy effects. Yet they are incompatible with the view that sector and subsector BIAs can use their specialised knowledge to get better access to actors in need of this type of information, e.g. working level bureaucrats and committees.

We therefore extended the range of access goods in two ways. First, we argued that decision-makers are receptive to an interlocutor's political relevance. BIAs representing a large share of the workforce should have particularly close contacts to elected politicians, as they may have some influence on a large group of voters. It turned out, however, that basically this argument does not hold true, as already noted by Graham K. Wilson (1990: 164-5). Second, representativeness - i.e. the ability to speak for the greater part of the respective business community - plays a greater role than expected. A higher level of representativeness increases the probability of having contacts with decision-makers in the member states as well as at EU level. Among the groups having access, representativeness has a differentiated effect: It does not allow for a better access to major representative institutions of parliamentary democracies: i.e. the parliamentary committees and members of parliament. ${ }^{3}$ Representativeness is also less important for national institutions than for EU institutions. With the Commission's new consultation regime and the Lisbon Treaty, representativeness has become a cherished principle in EU policy consultations. Accordingly, EU associations are given precedence and when the dialogue is extended to national BIAs they ought, at least, to fully represent their business sector.

Our findings are thus significant for the wider debate on the relevance of resources in EU lobbying. They reveal that not only material resources matter 
but also normative claims have a considerable impact. Furthermore, not all economic resources are important. Whereas the associations' financial resources have clear effects, the size of member firms' workforce does not. Thus, we reject the idea that business associations just bring the economic power of their constituencies to bear and add it to the overall power of the dominant member states. The real world is far more differentiated.

\section{Notes}

1. The directories used were: France: membership list of the Centre d'Etudes des Directeurs d'Associations Professionnelles (CEDAP) 2014; Mouvement des Entreprises de France 2011: L’Annuaire du MEDEF, Paris: Medef. Germany: Oeckl online Deutschland, Bonn: Festland Verlag GmbH (accessed 10 November 2014); Oeckl 2009: Taschenbuch des öffentlichen Lebens, Deutschland 2010, Bonn: Festland Verlag GmbH. Poland: Lista organizacji uprawnionych do wnoszenia środków ochrony prawnej w 2010r. Urząd Zamówień Publicznych, http://www.uzp.gov.pl/cmsws/page/?D;1290 (accessed 15 March 2012); Funkcjonowanie samorządu gospodarczego w Polsce, Ministerstwo Gospodarki, Departament Analiz i Prognoz, Warszawa 2007, http://www. mg.gov.pl/NR/rdonlyres/EECFD29E-4EE1-4B81-B38B-3421FD74C13E/31956/ FunkcjonowaniesamorzdugospodarczegowPolsce.pdf (accessed 15 March 2012). United Kingdom: Trade Association Forum, Trade Associations, http:// www.taforum.org/Members (accessed 23 June 2015 and 12 October 2011).

2. The standardised regression coefficients are fully in line with the b-coefficients and were not reported.

3. For the interaction of interest groups with the EP see Carroll and Rasmussen (2017).

\section{Acknowledgements}

We thank Rainer Eising, David Friedrich, Sebastian Fuchs and Arndt Wonka for helpful comments on earlier versions of this article. Jana Anzlinger and Franziska Jahn offered helpful research assistance. We also thank Hannah Laumann for proof reading. Without the many respondents from the national business interest associations who were willing to participate in the survey or to be interviewed, this research would not have been possible.

\section{Disclosure statement}

The authors declare no potential conflict of interests with respect to the research, authorship and/or publication of this article.

\section{Funding}

This work was supported by the Deutsche Forschungsgemeinschaft (DFG, German Research Foundation) [EUROLOB II - QU 333/1-1]. The research infrastructure was provided by the Mannheim Centre for European Social Research (MZES)/Mannheim University. 


\section{References}

Berkhout, Joost, Caelesta Braun, and Marcel Hanegraaff (2017). 'Is the EU Different? Comparing the Diversity of Dutch and European Systems of Interest Organizations', West European Politics, doi: 10.1080/01402382.2017.1308695.

Bernhagen, Patrick (2013). 'When Do Politicians Listen to Lobbyists (and Who Benefits When They Do)?', European Journal of Political Research, 52:1, 20-43.

Bernhagen, Patrick, and Neil J. Mitchell (2009). 'The Determinants of Direct Corporate Lobbying in the European Union', European Union Politics, 10:2, 155-76.

Beyers, Jan (2002). 'Gaining and Seeking Access: The European Adaptation of Domestic Interest Associations', European Journal of Political Research, 41:5, 585-612.

Beyers, Jan (2008). 'Policy Issues, Organisational Format and the Political Strategies of Interest Organisations', West European Politics, 31:6, 1188-211.

Beyers, Jan, and Bart Kerremans (2012). 'Domestic Embeddedness and the Dynamics of Multilevel Venue Shopping in Four EU Member States', Governance, 25:2, 263-90.

Binderkrantz, Anne S., Helene H. Pedersen, and Jan Beyers (2016). 'What is Access? A Discussion of the Definition and Measurement of Interest Group Access', European Political Science, doi: 10.1057/eps.2016.17.

Bouwen, Pieter (2002). 'Corporate Lobbying in the European Union: The Logic of Access', Journal of European Public Policy, 9:3, 365-90.

Bouwen, Pieter (2004). 'The Logic of Access to the European Parliament: Business Lobbying in the Committee on Economic and Monetary Affairs', Journal of Common Market Studies, 42:3, 473-95.

Carroll, Brendan, and Anne Rasmussen (2017). 'Cultural Capital and the Density of Organized Interests Lobbying the European Parliament', West European Politics, doi: 10.1080/01402382.2017.1303243.

Cekik, Aneta (2017). 'Adapting to Europe? Business Interests and Civil Society Groups in Accession Countries', Special Issue 2017, West European Politics, doi: 10.1080/01402382.2017.1308696. 
Chalmers, Adam William (2013). 'Trading Information for Access: Informational Lobbying Strategies and Interest Group Access to the European Union', Journal of European Public Policy, 20:1, 39-58.

Coen, David (2009). 'Business Lobbying in the European Union', in David Coen and Jeremy Richardson (eds.), Lobbying the European Union: Institutions, Actors, and Issues. Oxford: Oxford University Press, 145-68.

Dür, Andreas (2008). 'Interest Groups in the European Union: How Powerful Are They?', West European Politics, 31:6, 1212-30.

Dür, Andreas, and Gemma Mateo (2016). Insiders versus Outsiders. Interest Group Politics in Multilevel Europe. Oxford: Oxford University Press.

Dür, Andreas, Patrick Bernhagen, and David Marshall (2015). 'Interest Group Success in the European Union: When (and Why) Does Business Lose?', Comparative Political Studies, 48:8, 951-83.

Eising, Rainer (2004). 'Multilevel Governance and Business Interests in the European Union', Governance, 17:2, 211-45.

Eising, Rainer (2007). 'The Access of Business Interests to EU Institutions: Towards élite Pluralism?', Journal of European Public Policy, 14:3, 384-403.

Eising, Rainer (2009). The Political Economy of State-Business Relations in Europe. Interest Mediation, Capitalism and EU Policy-Making. London: Routledge.

Eising, Rainer, Daniel Rasch, Patrycja Rozbicka, Danica Fink-Hafner, Mitja Hafner-Fink, and Meta Novak (2017). 'Who Says What to Whom? Alignments and Arguments in EU Policy Making', West European Politics, doi: 10.1080/01402382.2017.1320175.

Greenwood, Justin (1997). Representing Interests in the European Union. Basingstoke: Macmillan.

Hafner-Fink, Mitja, Meta Novak, Danica Fink-Hafner, Rainer Eising, Daniel Rasch, and Patrycja Rozbicka (2016). 'Giants and Dwarfs: The Multilevel Lobbying Strategies of National Interest Organisations', Teorija in Praksa, 53:3, 605-624.

Hooghe, Liesbet, and Gary Marks (2001). Multi-Level Governance and European Integration. New York, NY: Rowman \& Littlefield Publishers.

Jasiecki, Krzysztof (2014). 'Europeanization of the Polish Economic Interests in the Light of the Varieties of Capitalism (VoC) Approach' Paper presented at the First Annual Research Symposium 2014: Territorialisation of Interest Representation in Times of Economic Crises, Willy Brandt Centre of German and European Studies, University of Wrocaw, Poland, 31 January-1 February 2014.

Jordan, Andrew (2001). 'The European Union: An Evolving System of Multi-Level Governance ... or Government?', Policy and Politics, 29:2, 193-208.

Klüver, Heike (2010). 'Europeanization of Lobbying Activities: When National Interest Groups Spill over to the European Level', Journal of European Integration, 32:2, 175-91.

Klüver, Heike (2012). Interessenvermittlung in der Europäischen Union. Nationale Verbände auf dem Weg nach Brüssel. Saarbrücken: AV Akademikerverlag.

Klüver, Heike (2013). Lobbying in the European Union. Interest Groups, Lobbying Coalitions, and Policy Change. Oxford: Oxford University Press.

Kohler-Koch, Beate (Forthcoming). 'Stability and Change in the Representation of Business Interests in Germany', MZES Working Papers, Mannheim: MZES.

Kohler-Koch, Beate, and Christine Quittkat (1999). 'Intermediation of Interests in the European Union', MZES Working Papers 31, Mannheim: MZES.

Kohler-Koch, Beate, and Christine Quittkat (2016). 'New and Not-So-New Trends in the Representation of Economic Interests in the EU: EUROLOB II Report 2016, MZES Working Papers 165, Mannheim: MZES. 
Lowery, David (2013). 'Lobbying Influence: Meaning, Measurement and Missing', Interest Groups \& Advocacy, 2:1, 1-26.

Marchetti, Kathleen (2015). 'The Use of Surveys in Interest Group Research', Interest Groups \& Advocacy, 4:3, 272-82.

Marks, Gary, Liesbet Hooghe, and Kermit Blank (1996). 'European Integration from the 1980s: State-Centric v. Multi-Level Governance', Journal of Common Market Studies, $34: 3,341-78$.

Oeckl (2009). Taschenbuch des öffentlichen Lebens, Deutschland 2010. Bonn: Festland Verlag $\mathrm{GmbH}$.

Offe, Claus, and Helmut Wiesenthal (1980). 'Two Logics of Collective Action: Theoretical Notes on Social Class and Organizational Form', Political Power and Social Theory, 1:1, 67-115.

Pappi, Franz U., and Christian H.C.A. Henning (1999). 'The Organization of Influence on the EC's Common Agricultural Policy: A Network Approach', European Journal of Political Research, 36:2, 257-81.

Quittkat, Christine (2006). Europäisierung der Interessenvermittlung. Französische Wirtschaftsverbände zwischen Beständigkeit und Wandel. Wiesbaden: VS-Verlag für Sozialwissenschaften.

Reutter, Werner, ed. (2012). Verbände und Interessengruppen in den Ländern der Europäischen Union. Wiesbaden: VS-Verlag für Sozialwissenschaften.

Saurugger, Sabine (2008). 'Interest Groups and Democracy in the European Union', West European Politics, 31:6, 1274-91.

Schmidt, Vivien A. (2006). Democracy in Europe. The EU and National Polities. Oxford: Oxford University Press.

Traxler, Franz, and Gerhard Huemer, eds. (2007). Handbook of Business Interest Associations, Firm Size and Governance. A Comparative Analytical Approach. London/ New York: Routledge/Chapman \& Hall.

Truman, David (1951). The Governmental Process. Political Interests and Public Opinion. Westport, CT: Greenwood Press.

Vannoni, Matia (2013). 'The Determinants of Direct Corporate Lobbying in the EU: A Multi-Dimensional Proxy of Corporate Lobbying', Interest Groups \& Advocacy, 2:1, 71-90.

Wilson, Graham K. (1990). Interest Groups. Oxford: Basil Blackwell.

Wonka, Arndt (2017). 'German MPs and Interest Groups in EU Multilevel PolicyMaking: The Politics of Information Exchange', West European Politics, doi: 10.1080/01402382.2017.1303247.

\section{Appendix 1}

Table A1. Rate of return Eurolob II.

\begin{tabular}{lccccc}
\hline & Germany & France & Poland & UK & Total \\
\hline$N$ & 553 & 394 & 132 & 436 & 1515 \\
Participation $(N)$ & 205 & 92 & 50 & 100 & 447 \\
Participation $(\%)$ & 37.1 & 23.4 & 37.9 & 22.9 & 29.5 \\
\hline
\end{tabular}




\title{
Adapting to Europe? Business interests and civil society groups in accession countries
}

\author{
Aneta Cekik
}

\begin{abstract}
While the Europeanisation of national interest groups is an important research agenda in the EU, very little research examines their Europeanisation outside the $\mathrm{EU}$, and during the EU accession process. The article fills this gap by focusing on Europeanisation of interest groups in Macedonia, Montenegro and Serbia. Using new survey data, the article looks at interest groups' involvement in the national pre-accession process, and their activity at the EU level. The main argument of the paper stresses the absence of significant differences between the levels of Europeanisation of business and other types of interest groups (especially NGOs) in the current phase of EU accession. The regression analyses provide support to this argument, showing that access to national institutions, resources, the Europeanisation of policy areas and dependence on EU funding account for interest groups' levels of Europeanisation, while variations across group types are not very significant.
\end{abstract}

Most studies on the Europeanisation of interest groups focus on groups from current and, especially, older European Union member states. But being considerably affected by the EU accession process, interest groups from EU accession countries also take into consideration their future EU membership and try to adapt to the EU accession process. This makes their activity an important research agenda.

However, studies on the Europeanisation of interest groups from newer post-communist member states are still rare (for exceptions, see Blavoukos and Pagoulatos 2008; Císař and Vráblíková 2012) and studies on interest groups during the $\mathrm{EU}$ accession process are almost non-existent (some exceptions are Fagan 2010; Fink-Hafner 1998). Previous research is mostly of a qualitative nature, focusing on specific case studies (Koutalakis 2010; Sudbery 2010), 
types of groups (Börzel and Buzogány 2010), or single countries (Fink-Hafner et al. 2015; Hristova and Cekik 2015). In this article, I analyse how interest organisations in the post-communist democracies of Macedonia, Montenegro and Serbia have responded to the challenge of accession to the EU drawing on survey data and covering various types of interest groups. Other than previous research (Beyers 2002: 593; Dür and Mateo 2016) would suggest, I argue that business associations in EU accession countries are not more Europeanised than other types of interest groups, particularly non-governmental organisations (NGOs). This is especially the case when it comes to their EU-level activity. Business associations in these countries still keep the national level as their main level of activity and adapt only slowly to the EU lobbying style. In contrast, NGOs show significant levels of Europeanisation because EU-related funding is of particular importance for their organisational survival. The following empirical analysis supports this argument, indicating that the embeddedness in domestic politics, resource dependencies and policy areas are important factors for interest groups' Europeanisation.

To examine the Europeanisation of interest groups, first, I look at the importance of the EU level of governance and EU political developments for interest groups. Second, I examine their involvement in national level consultations during the EU accession process and their participation in EU-related events organised by national political institutions. Finally, I look at EU-level activity of interest groups via their membership in EU-level associations and contacts with EU institutions.

The article adds to the study of the Europeanisation of interest groups by testing factors that figure prominently in this literature in new contexts and by shedding light on the particularities of interest organisations operating in post-communist political systems.

I first develop my arguments using the existing literatures on EU lobbying, the Europeanisation of interest groups, and on civil society in the post-communist democracies of Central and Eastern Europe. I then explain the research design and empirical results. The conclusion summarises the main argument and the findings of the paper.

\section{Theoretical background}

The Europeanisation of interest groups refers to the effects of European integration on national interest groups and practices of interest intermediation. European integration leads to the adaptation of interest groups to EU policymaking and affects their political strategies and action repertoires (Beyers 2002; della Porta and Caiani 2007; Saurugger 2005). Although there are important differences across policy sectors, the effects of European integration are farreaching also for the national systems of interest intermediation (Falkner 2000). When it comes to the adaptation of interest groups, Europeanisation is 
commonly defined as the importance attributed to the EU level of governance (Beyers 2002) and the spillover of interest group activity to the EU level (Klüver 2010). Dür and Mateo (2016) operationalise Europeanisation as the share of time interest groups devote to lobbying on EU legislation, and that spent on lobbying EU institutions. While the literature often captures interest group activity at the EU level, the Europeanisation of national interest intermediation is less frequently examined.

I examine Europeanisation looking at the attitudes and activities of interest groups, as well as the national interest representation practices related to EU accession. First, I capture the general orientation of interest groups towards the EU by examining the importance they attribute to the EU level of governance and monitoring of EU political developments. Second, I study their activities at the domestic level related to the $\mathrm{EU}$ accession process, namely their taking part in consultations on the transposition of EU legislation, their participation in accession-related events organised by political institutions, the programming of EU funds, etc. Through the politics of conditionality in post-communist countries, the EU explicitly demands governments to consult interest groups in the national political process. The ultimate goal of this pressure is not only related to $\mathrm{EU}$ accession, but to the functioning of the democratic process in general. Finally, I analyse the most commonly studied activities in the Europeanisation literature on interest groups: their membership in EU peak associations and their direct lobbying contacts with EU institutions.

Previous research demonstrates that national interest groups as 'carriers of Europeanization' (della Porta and Caiani 2007) try to influence EU politics by lobbying national officials and by being active at the EU level, in addition to the national route. Researchers also hypothesised that interest groups either try to overcome their weakness at national level by acting directly at the EU level (Beyers 2002; Beyers and Kerremans 2012; Eising 2007), or that they engage in EU lobbying foremost because of its greater effectiveness (Dür and Mateo 2016). While early studies of EU lobbying showed that business actors were pioneers among the various types of interest groups to reach the EU arena (Aspinwall and Greenwood 1998; Mazey and Richardson 1993), the current literature examines various factors accounting for the interest groups' levels of Europeanisation including organisational characteristics, resources, policy areas and national interest intermediation practices (Beyers 2002; Dür and Mateo 2016; Eising 2007). Business interests are frequently considered to be most successful in terms of presence in Brussels, contacts with EU institutions and the ability to exert influence (Bouwen 2004; Mahoney 2004), although newer research came to somewhat different conclusions (Beyers and Kerremans 2012; Dür et al. 2015). NGOs, on the other hand, are considered to be less prone to Europeanisation because of their scarce resources for transnational lobbying, and because of the importance of national-level activity for their goals of securing membership and support (Dür and Mateo 2016). I examine the relevance 
of these factors in post-communist countries and during the period before accession to the EU. Given that in post-communist political systems many NGOs were established only after 1990, while most business associations had already served rather different purposes during socialism, differences between old and new democracies can be expected.

\section{Interest groups in post-communist democracies on the path to EU accession}

In post-communist democracies, the role of international actors in domestic politics, including the structuring of the interest groups systems, is quite significant. Since the 1990s, international donors have been important for funding non-governmental citizen organisations, particularly the activities of liberal groups, contributing to a larger number of associations with higher levels of professionalisation (Carmin 2010; Uhlin 2006). In the domain of economic interest groups, the International Labour Organization and the World Bank have initiated the creation of new organisations in accordance with the practices of Western democracies (employers' associations, most noticeably) and supported the pluralisation of interest representation systems. With the start of the EU accession process, the EU became increasingly involved in these processes. EU accession demands are generally in line with the activities of the abovementioned organisations, but go even further in affecting interest groups and their relationship with political institutions. As part of the current EU conditionality, the EU institutions have placed more attention on the inclusion of interest groups in the $\mathrm{EU}$ accession process and in national politics in general, compared to the 2004 and 2007 enlargement wave. Owing to this pressure, national governments now consult interest groups on various issues related to the transposition of EU legislation, introduce practices of parliamentary committee hearings involving the civil society, and even make changes in their laws which regulate the participation of interest groups in the preparation of public policy (Hristova and Cekik 2015). Nonetheless, the quality of involvement is assessed as being low and insufficient (Fagan 2010).

Many national interest groups try to adapt to these processes. According to the literature on the Eastern enlargement, EU accession effects vary depending on the type of group. Business associations have received special attention from both the European Commission and EU-level associations. These provided support for their professional development to prepare the newcomers for EU membership (Fink Hafner 1998; Pérez-Solórzano Borragán 2006). They had great incentives and opportunities to be involved in the transposition of EU legislation in the technical areas of the Single Market (Koutalakis 2010). Special emphasis was also placed on the tripartite social dialogue (Pérez-Solórzano Borragán and Smismans 2012). Results in terms of their adaptation to the EU were assessed in some cases partly positively (Mansfredova 2007 on the 
Czech Republic) while in others as 'contradictory' (Grosse 2010 on Poland and Estonia). When it comes to NGOs, the EU has become a powerful tool for their national-level activity, although this conclusion refers mostly to the period after accession (Císař and Vráblíková 2012; Sudbery 2010).

I argue that, in the current enlargement wave, NGOs are not significantly less Europeanised than business groups. This is for two reasons. First, the EU pressure for increased consultation of interest groups is especially beneficial for groups that do not enjoy insider positions in domestic policy-making. Second, the $\mathrm{EU}$ is an important donor in these countries. In some of them it is even the largest donor (Balkan Civil Society Development Network 2012). The substantial EU funding for civil society provides strong incentives for NGOs to monitor EU-level developments, and to keep close contacts with EU institutions and EU-level networks. Business, professional associations and trade unions have more stable funding secured by their (compulsory) membership fees. Thus, NGOs will pay at least as much attention to the EU level of governance as business associations.

H1. The EU level of governance is not less important to NGOs than it is to business associations.

Regardless of the EU's pressure, however, national institutions are still in a position to select their partners in the policy-making process using other criteria. During the transition period of post-communist countries to democracy and capitalism, many NGOs are engaged in watchdog activities. Due to their continued monitoring of democratic standards and government behaviour, political institutions remain suspicious of their activity (Císař and Vráblíková 2012: 143-4; Komar 2015). Business, on the other hand, remains a stable partner of political institutions because of the significance of EU policies that regulate the Single Market. In addition, in Macedonia, Montenegro and Serbia, although a pluralism of association is allowed, business' political interests are usually represented by large cross-sectoral associations, some of which were already established under communist rule and still enjoy privileged access. The same is the case with trade unions, which are part of the tripartite (neo-corporatist) institutions in these countries.

More generally, as previous research suggests (Beyers and Kerremans 2007, 2012; Eising 2004), interest groups that are well embedded in domestic politics should also be more frequently involved in national consultations on EU-related issues. Thus, I expect:

H2. Interest groups with a better access to national institutions are also more involved in the national EU accession process.

My second set of arguments refers to the activity of interest groups at the EU level. Interest groups from post-communist EU member states are only slowly adapting to the EU policy process. They display lower levels of EU-level activity compared to interest groups from Western and Northern Europe 
(Eising et al., 2017; Obradovic and Damsma 2007; Pleines 2010). This applies also to business associations (but see Kohler-Koch et al., 2017) and large firms. Sallai (2013) demonstrates that communist networking and clientelistic relations with national institutions still have effects on the ability of these actors to adapt to the EU lobbying environment. Due to their embeddedness in domestic contexts, I argue that business interests in the EU accession countries primarily opt for lobbying via the national route and are not much more active at EU level than NGOs. For example, in Macedonia, the biggest chamber of commerce maintains only formal/protocol relations with the EU institutions. The only nationwide and broadly cross-sectoral representative employers' association is still not a member of Business Europe. The biggest agricultural association which had a Brussels office from 2008 to 2010 (financed by foreign sources) did not make effective use of its Brussels presence (Hristova and Cekik 2015). Neither the biggest chambers of commerce of Macedonia and Montenegro nor any other business associations are currently present in Brussels with their own offices. In Serbia, only the largest chamber of commerce maintains an office in Brussels. NGOs on the other hand try to use the opportunities introduced by EU conditionality to increase their influence at the national level. They seek to compensate their national-level weakness by also addressing the EU institutions.

$\mathrm{H} 3 \mathrm{a}$. Business associations are not more likely to be members of EU-level associations than NGOS.

$\mathrm{H} 3 \mathrm{~b}$. Business associations do not maintain more direct contacts with EU institutions than NGOs.

In accordance with the existing literature (Dür and Mateo 2016; Eising 2004), I expect interest groups' resources (budget and staff) to be good predictors of their Europeanisation, since significant resources are needed to monitor EU political developments and to engage in multi-level lobbying.

H4. The more resources an association commands the more active will it be at EU level.

I also expect the effect of policy areas to be in line with the findings in previous research (Beyers and Kerremans 2007; Dür and Mateo 2016), that is:

H5. Interest groups active in policy areas with strong EU competences will be more Europeanised.

In terms of control variables, the age of associations can be an important factor, since significant experience is needed for performing multi-level lobbying (e.g. Eising et al., 2017). Hence, associations established only after the fall of communism might be less Europeanised than older groups. ${ }^{1}$ I do not expect remarkable cross-national variations, since the selected countries share great similarities with regard to the level of democratic and economic development, the structures of interest group populations and the practices of 
interest mediation. They differ, however, when it comes to the initiation of the $\mathrm{EU}$ accession process in one crucial aspect. In Macedonia, the EU accession process was initiated earlier (in 2001) than in Montenegro (2007) and Serbia (2009) such that interest groups in Macedonia may experience higher levels of Europeanisation. Furthermore, 'dissident' civil society during the 1980s was more developed in Serbia than in Macedonia and Montenegro which were mainly inert followers as small republics in Yugoslavia. Finally, although all three countries are small states when compared to the average EU member state, Serbia is four times larger than Macedonia, and more than 10 times larger than Montenegro. This may have a positive effect on the size and resources of associations and their ability to become multi-level players.

\section{Data and operationalisation}

The data used in this article were collected by means of a survey of associations in Macedonia, Montenegro and Serbia that was conducted between April and October 2014. The survey covered the total population of interest groups with internet presence (visible interest groups): 493 in Serbia, 297 in Macedonia and 201 in Montenegro. While all sectoral chambers, employers' associations and branch trade unions within national-level federations are included in the study, the requirement of an online presence may exclude very small associations, especially NGOs, and some professional associations for which there exists a scarcity of information. To ensure a broad coverage of the survey, I include also associations which instead of an organisational web page maintain blogs or social media profiles. While for the needs of this article, the targeted population is suitable, because significant resources are needed for engaging in EU affairs, the sample may be biased towards including a disproportionate share of more Europeanised groups.

Various sources were used to compile the survey population, including official registers, voluntary (unofficial) directories, NGO publications and other sources (see online appendix I). The national populations are remarkably similar and dominated by citizen associations/NGOs: more than $50 \%$ of the interest groups are NGOs (Table 1). This percentage is even higher if one looks at official registers of associations (see online appendix I). The large majority of NGOs were formed only after the introduction of political pluralism in the

Table 1. The composition of the populations and samples by country and group type (\%).

\begin{tabular}{|c|c|c|c|c|c|c|c|c|c|c|c|c|}
\hline & \multicolumn{6}{|c|}{ Population } & \multicolumn{6}{|c|}{ Sample } \\
\hline & TU & $B A$ & PA & NGO & Oth. & $\mathrm{N}$ & TU & BA & PA & NGO & Oth. & $\mathrm{N}$ \\
\hline Macedonia & 11.7 & 16.6 & 5.5 & 56.2 & 10.0 & 297 & 8.7 & 16.5 & 4.3 & 61.7 & 9.0 & 115 \\
\hline Montenegro & 12.4 & 14.5 & 15.4 & 50.2 & 7.5 & 201 & 10.3 & 17.2 & 15.5 & 51.7 & 5.2 & 58 \\
\hline Serbia & 17.0 & 10.5 & 12.8 & 54.4 & 5.3 & 493 & 9.8 & 13.6 & 7.6 & 64.4 & 4.5 & 132 \\
\hline
\end{tabular}

Note:TU-trade union; BA - business association; PA - professional association; NGO - non-governmental association; Oth. - other.

Source: Survey of interest groups in Macedonia, Montenegro and Serbia conducted by the author. 
1990s, while a significant number of trade unions, chambers of commerce and professional associations existed already during socialism. Competition within these representative domains is rare: the interests of workers and firms are typically represented by nationwide umbrella associations. The number of business associations outside the system of chambers of commerce is still small. The greatest organisational concentration in the interest group system exists in Montenegro, which is by far the smallest country in this analysis.

Associations were asked to fill in the questionnaire online; to those which did not do so after three invitations, it was sent by regular mail. The overall response rate is $31 \%$, ranging from $27 \%$ in Serbia (132 associations) and $29 \%$ in Montenegro (58 associations) to $40 \%$ in Macedonia (115 associations). Comparisons of the age and types of groups present in the population and among the respondents show that the characteristics of the sample resemble those of the population (see Table 1 and online appendix II). The conclusions drawn may therefore be regarded as being representative of the population from which the sample was drawn. Interest associations were grouped into several categories: trade unions, business associations, professional associations, citizen associations (NGOs), as well as the category 'other' $(N=19)$ which mainly consists of think tanks $(N=15)$ and foundations $(N=4)$ that fund activities in the areas of democratisation, civil society capacity building and perform research. ${ }^{2}$

\section{Dependent and explanatory variables}

To construct the dependent variables, I use the responses to a block of questions related to the $\mathrm{EU}$ and the accession process. Interest groups could rate the importance of the EU level of governance and of monitoring political developments at the EU level on a five-point scale, where 1 means 'not at all important' and 5 is 'very important'. The scores of the responses to these two questions were used to construct the first dependent variable: the importance of the EU level. In relation to the $\mathrm{EU}$ accession process within their country the interest groups were asked how frequently (never, rarely, sometimes or often) they: have been consulted by political institutions on issues falling within their areas of expertise; have participated in parliamentary committees' hearings; have participated in forums/conferences organised by political institutions; have participated in the working groups of negotiations (only for Serbia and Montenegro; accession negotiations for Macedonia have not yet started); have been consulted during the preparation of the responses to the EC questionnaire; have participated in the programming of EU pre-accession funds; and have been involved in any other activities. The scores on these questions were used to construct the second index/dependent variable: the inclusion in the national EU accession process.

With regard to their EU-level activity, the interest groups were asked if they are members or have an observer status in some EU-level associations, and how they rate the usefulness of this membership (on a scale from 1 to 5 , where 1 is 
'not at all useful' and 5 is 'very useful'). Furthermore, they should indicate the frequency of contacts (never, rarely, sometimes or often) with the following EU institutions: European Commission, European Parliament (EP), EU regulatory agencies, European Economic and Social Committee (EESC) and Committee of the Regions. To construct the dependent variable EU contacts, the sum of scores for contacts with the Commission, the $\mathrm{EP}$ and EU regulatory agencies were used. All dependent variables were recoded to start at 0 .

Regarding the potential explanations of interest groups' Europeanisation, aside from group type, staff, budget and policy areas can be important determinants of interest group activity. To measure the Europeanisation of policy areas in which the groups are active, I constructed a composite variable summing up the scores for the importance that groups assign to several policy areas with significant EU competences (civil and human rights, agriculture, consumer policy, environment, migration, trade and transport) (see Dür and Mateo 2016). I added the area of civil and human rights to the highly Europeanised sectors, since these topics have a prominent place in the EU conditionality policy. To measure their resource dependency on the $\mathrm{EU}$, a variable indicating whether the groups receive EU funding was included. The groups' embeddedness in national politics is measured by the variable 'national access', which is a composite index of their contacts with the executive (working and ministerial level), the parliament (members of parliament, political parties and parliamentary working bodies), the national regulatory agencies, the local self-government institutions, and other institutions they could additionally indicate. Its original values range from 1 to $6: 1$ indicates no contacts and 6 denotes weekly contacts. Finally, I also control for the country of origin and the age of associations.

\section{Results}

\section{Importance of EU-level governance and EU funds for interest groups}

I begin by presenting the descriptive findings. The interest associations in Macedonia, Montenegro and Serbia are highly interested in EU political developments and consider the EU level of governance not much less important for their activity than the national and local levels. On a scale from 1 to 5 where 1 is 'not at all important' and 5 is 'very important', the importance of monitoring EU political developments has a mean score of 3.8 whereas that for monitoring national political developments amounts to 4.1. A comparison of the importance business associations and NGOs attach to the EU level of governance supports Hypothesis 1 . There is no statistically significant difference among these types of groups with regard to their monitoring of EU political developments. Put otherwise, for $75 \%$ of the interest groups in Macedonia, $78 \%$ of the interest groups in Serbia and $81 \%$ of the interest groups in Montenegro, the EU level of governance is 'important' or 'very important'. All in all, the EU 
is more important than international institutions, and slightly less important than national and local institutions (Table 2).

As mentioned, EU funding is important for interest groups in the accession countries (see Table 3). In Macedonia and Serbia, more than half of the groups receive some kind of EU funding. In Montenegro, this amounts to 39\%. In the three countries, significant portions of the categories 'other groups' (89\%) and NGOs (60\%), but also of business associations (50\%) receive EU funding, while only a small number of trade unions and professional associations obtain EU funds (see Table 4). Other international funding is also important, especially to NGOs and 'other groups'. The structure of resource dependencies varies greatly across the different group types. More than $96 \%$ of the trade unions and business associations, and almost $80 \%$ of the professional associations rely on membership fees in comparison to $31 \%$ of NGOs and $11 \%$ of others. Interest

Table 2. Importance of different levels of government by country (\%).

\begin{tabular}{lccc}
\hline & Macedonia & Montenegro & Serbia \\
\hline Local level & 81.7 & 81.0 & 81.0 \\
National level & 90.4 & 89.6 & 90.7 \\
European (EU) level & 74.8 & 81.0 & 77.9 \\
International level & 67.8 & 75.8 & 74.1 \\
\hline
\end{tabular}

Note: Percentage of groups finding a level of government 'important' or 'very important'.

Source: Survey of interest groups in Macedonia, Montenegro and Serbia conducted by the author.

Table 3. Sources of income by country (\%).

\begin{tabular}{llccc}
\hline & All & Macedonia & Montenegro & Serbia \\
\hline Membership fee & 50.7 & 53.2 & 48.2 & 49.6 \\
Payments for services to members & 22.6 & 23.4 & 16.1 & 24.8 \\
Income from own products and services & 26.4 & 27 & 17.9 & 29.5 \\
Funds from public sources & 50 & 34.2 & 58.9 & 59.7 \\
Funds from private sources & 45 & 35.1 & 44.6 & 43.4 \\
Funds from EU sources & 52 & 55.9 & 39.3 & 54.3 \\
Funds from other foreign sources & 58.8 & 73 & 46.4 & 51.9 \\
Other & 5.1 & 3.6 & 5.4 & 6.2 \\
\hline
\end{tabular}

Note: Percentage of groups funded by specific kinds of funds.

Source: Survey of interest groups in Macedonia, Montenegro and Serbia conducted by the author.

Table 4. Sources of income by group type (\%).

\begin{tabular}{lccccc}
\hline & TU & BA & PA & NGO & Oth. \\
\hline Membership fee & 96.6 & 97.8 & 79.2 & 31.3 & 11.1 \\
Payments for services to members & 10.3 & 73.9 & 25 & 12.3 & 11.1 \\
Income from own products and services & 3.4 & 32.6 & 37.5 & 25.7 & 38.9 \\
Funds from public sources & 3.4 & 30.4 & 50 & 64.2 & 33.3 \\
Funds from private sources & 17.2 & 28.3 & 37.5 & 49.2 & 27.8 \\
Funds from EU sources & 10.3 & 50 & 25 & 59.2 & 88.9 \\
Funds from other foreign sources & 17.2 & 28.3 & 33.3 & 73.2 & 94.4 \\
Other & 0 & 2.2 & 8.3 & 5.6 & 11.8 \\
\hline
\end{tabular}

Note: Percentage of groups funded by specific kinds of funds. TU - trade union; BA - business association; PA - professional association; NGO - non-governmental association; Oth. - other.

Source: Survey of interest groups in Macedonia, Montenegro and Serbia conducted by the author. 
groups receiving EU funds find the EU level of governance more important $(M=4.3)$ than those that do not $(M=3.9)(t=3.554 ; p<0.01)$. Likewise, monitoring EU developments is more important to the former $(M=4.1)$ than to the latter $(M=3.7)(t=3.237 ; p<0.01)$.

\section{Involvement in the national EU accession process}

The participation in national consultation procedures shows important similarities but indicates also some differences across countries (see Figure 1). Interest groups in Macedonia, where the accession process has lasted longer than in the other countries, are more involved in the national EU accession process than groups in Montenegro and Serbia. In all three countries, consultations on issues in their areas of expertise and participation in forums/conferences organised by political institutions are the most common forms of interest group involvement in the EU accession process. The level of involvement in these subjects is considerable: $53.1 \%$ of the groups in Macedonia, $47.4 \%$ of the groups in Montenegro and 39.3\% of the groups in Serbia have 'sometimes' or 'often' been consulted; $61.2 \%$ of the groups in Macedonia, 38.6\% of the groups in Montenegro and $44.5 \%$ of the groups in Serbia have participated in forums/ conferences organised by the political institutions; around one-third of the groups have taken part in consultations on the preparation of responses to the EC questionnaire or in the programming of pre-accession EU funds for their countries; as much as $42 \%$ of the groups in Montenegro and 23.8\% of the groups in Serbia were involved in working groups for negotiations with the EU (which have not yet started in Macedonia).

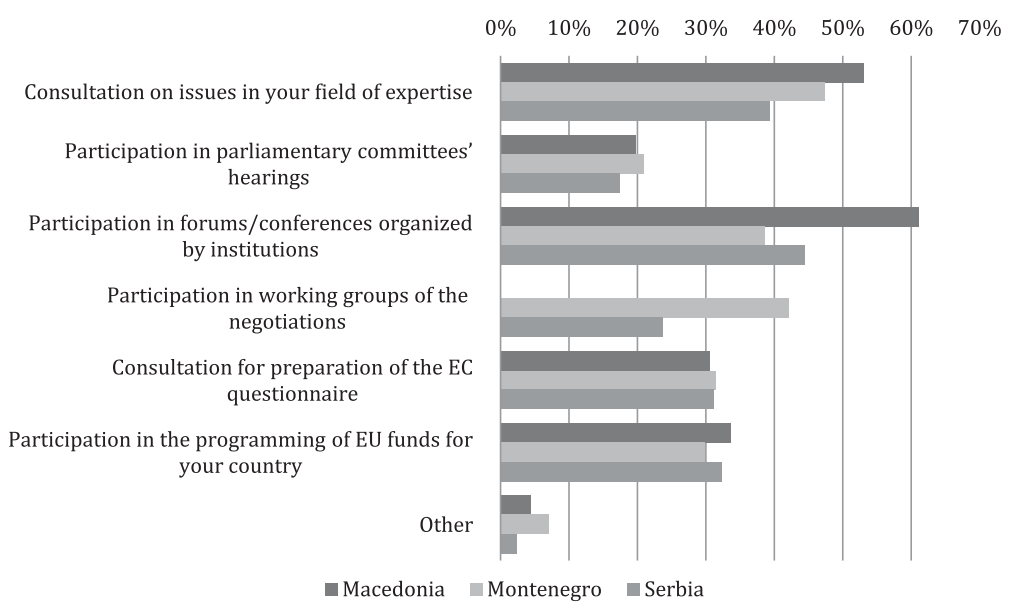

Figure 1. Participation in the national EU accession process by country.

Source: Survey of interest groups in Macedonia, Montenegro and Serbia conducted by the author. Note: Percentages of groups which sometimes or often participate in these types of activities. 
Table 5. Participation of interest groups in national-level activities related to EU accession.

\begin{tabular}{|c|c|c|c|c|c|c|}
\hline & Trade unions & Business & Professional & NGO & Oth. & $X^{2} ; \mathrm{d} f=4$ \\
\hline $\begin{array}{l}\text { Consultation } \\
\text { on issues in } \\
\text { IG's field of } \\
\text { expertise }\end{array}$ & 31 & 54 & 42 & 45 & 57 & ns \\
\hline $\begin{array}{l}\text { Participation in } \\
\text { parliamentary } \\
\text { committees' } \\
\text { hearings }\end{array}$ & 21 & 27 & 8 & 15 & 50 & $\begin{array}{c}14.452 \\
P<0.01\end{array}$ \\
\hline $\begin{array}{l}\text { Participation in } \\
\text { forums/confer- } \\
\text { ences organ- } \\
\text { ised by political } \\
\text { institutions }\end{array}$ & 41 & 53 & 29 & 51 & 72 & $\begin{array}{c}8.785 \\
P<0.1\end{array}$ \\
\hline $\begin{array}{l}\text { Participation in } \\
\text { working group } \\
\text { of the negoti- } \\
\text { ations }\end{array}$ & 32 & 50 & 10 & 28 & 22 & $\begin{array}{c}8.902 \\
P<0.1\end{array}$ \\
\hline $\begin{array}{l}\text { Consultation dur- } \\
\text { ing preparation } \\
\text { of the respons- } \\
\text { es of the EC } \\
\text { questionnaire }\end{array}$ & 17 & 56 & 17 & 28 & 39 & $\begin{array}{c}18.687 \\
P<0.01\end{array}$ \\
\hline $\begin{array}{l}\text { Participation in } \\
\text { the program- } \\
\text { ming of EU } \\
\text { funds }\end{array}$ & 10 & 44 & 17 & 32 & 56 & $\begin{array}{c}16.565 \\
p<0.05\end{array}$ \\
\hline
\end{tabular}

Note: Percentages of groups which sometimes or often participate in these types of activities. ns - not significant.

Source: Survey of interest groups in Macedonia, Montenegro and Serbia conducted by the author.

When grouping these responses in binary variables with values 0 for 'never' and 'rarely' taking part in these forms of involvement, and 1 for 'sometimes' and 'often' taking part, overall, business associations and 'other groups' are more involved in the national EU accession process than NGOs and, for that matter, trade unions. Professional associations are least involved, except when it comes to the consultation on issues in their areas of expertise (Table 5).

These results are in line with Hypothesis 2, which implied a higher extent of business involvement in the national EU accession process. Groups with a high level of professionalisation and expertise such as think tanks are also highly involved in the domestic accession process.

\section{EU-level activity}

\section{Membership in EU-level associations}

One of the most common forms of EU-level activity is the membership in EU-level umbrella associations. Through such membership, national interest groups obtain information about EU policies and legislation, learn how to socialise at EU level and get help in establishing contacts with EU institutions 
(Eising, 2017; Pérez-Solorzano Borragan 2001). EU-level associations are particularly important for national interest groups with limited resources that cannot afford a continuous presence in Brussels. But only around 20\% of the surveyed associations are members of EU-level associations. Trade unions (34\%) and professional associations (33\%) are more likely to join EU-level peak associations, whereas the proportion of business associations is only slightly above the average (24\%). Only $17 \%$ of the NGOs and $11 \%$ of the other groups are members of EU-level associations or networks. This is evidence against Hypothesis $3 \mathrm{a}$ and might be due to the tradition of international networking in the trade union movement and in the professions, which dates back to communist times.

Interest groups that have joined EU-level associations tend to find that their membership is useful. Indicating the usefulness of different aspects of their membership on a scale ranging from 1 which is 'not at all useful' to 5 which is 'very useful' they obtain average scores that are higher than 4.2. This is with regard to obtaining information in their areas of expertise, networking with similar organisations, training and capacity building, participation in joint projects, knowledge of EU interest representation, and contacts with EU institutions.

Interest groups in Macedonia seem to be better integrated and more active within EU-level associations (Figure 2): 80\% participate in formal events and $76 \%$ participate at least sometimes in the working groups of EU-level associations. The proportions are around 54\% in Montenegro and Serbia for participation in annual events, and $36 \%$ and $44 \%$, respectively, for participation in the activities of working groups. Groups from all three countries participate in regional training and events organised by EU-level associations. Participation

0\% 10\% 20\% 30\% 40\% 50\% 60\% 70\% 80\% 90\%

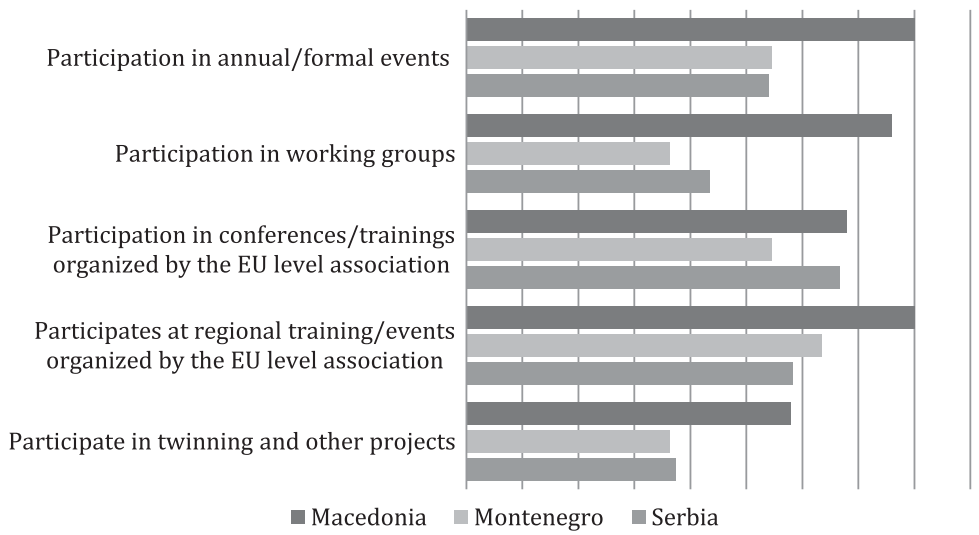

Figure 2. Activity of national groups in EU-level associations.

Source: Survey of interest groups in Macedonia, Montenegro and Serbia conducted by the author. Note: Percentage of groups which sometimes or often participate in these types of activities. 
in twinning or other projects tends to be the least frequent activity. However, in Macedonia 58\% of the associations also take part in this activity.

\section{Contacts with EU institutions}

The contacts of interest groups with EU institutions tend to be rare and aim mostly at the European Commission. Table 6 presents the percentage of groups which 'sometimes' or 'often' have contacts with EU institutions, by group type.

These results support Hypothesis $3 \mathrm{~b}$ stating that business associations are not more often in touch with the EU institutions than NGOs. Surprisingly, when compared to findings on the Europeanisation of interest groups from Western European member states, think tanks and foundations (the category 'other groups') are most often in contact with the European Commission, the European Parliament and EU regulatory agencies. Note also that NGOs have more frequent contacts with the Commission and the EP than business associations. These have the most frequent contacts only with the consulting EU institutions ECOSOC and Committee of the Regions. Around 17\% of trade unions are regularly in touch with the Commission and ECOSOC, while less than $10 \%$ of the professional associations maintain contacts with the Commission and with EU regulatory agencies.

\section{Empirical analysis of the Europeanisation of interest groups in accession countries}

Above, I presented five hypotheses on factors that shape interest group Europeanisation. In contrast to existing research, I argued that differences between business interests and non-governmental groups are less pronounced in accession countries than in established EU member states regarding the importance of the EU to these groups (H1), their membership in EU-level interest groups and contacts with EU institutions ( $\mathrm{H} 3 \mathrm{a}, 3 \mathrm{~b})$. In line with existing research I claim that policy insiders will be more involved in the accession

Table 6. Contacts with EU institutions by group type (\%).

\begin{tabular}{lccccc}
\hline & $\begin{array}{c}\text { Business } \\
\text { Associations }\end{array}$ & Trade unions & $\begin{array}{c}\text { Professional } \\
\text { associations }\end{array}$ & NGOs & Other \\
\hline $\begin{array}{l}\text { European Commis- } \\
\quad \text { sion }\end{array}$ & 22.7 & 17.2 & 8.4 & 30.9 & 50.0 \\
$\begin{array}{l}\text { European Parliament } \\
\text { EU regulatory }\end{array}$ & 9.1 & - & - & 10.1 & 38.9 \\
$\quad$ agencies & 18.2 & 10.3 & 4.2 & 8.4 & 22.3 \\
$\begin{array}{l}\text { ECOSOC } \\
\text { Committee of the }\end{array}$ & 18.2 & 17.2 & - & 7.8 & 5.6 \\
$\quad$ Regions & 18.1 & 6.8 & - & 4.5 & 5.6 \\
\hline
\end{tabular}

Note: Percentage of groups which 'sometimes' or 'often' have contacts with the EU institutions.

Source: Survey of interest groups in Macedonia, Montenegro and Serbia conducted by the author. 
process than policy outsiders (H2). Moreover, a higher level of resources should facilitate adaptation to the EU (H4) and a greater amount of activities in policy areas in which the EU enjoys many competencies should spur greater Europeanisation efforts (H5), particularly in regard to the establishment of direct contacts with EU institutions.

I will now test these propositions by means of regression analysis. Table 7 presents the definitions of variables and their descriptive statistics. The first three columns in Table 8 present the outcomes of three linear regression analyses on indexes constructed to measure the importance of the EU level, the extent of participation in national accession processes, and the amount of direct contacts with the EU institutions. The first index is a composite variable of the values of the EU's importance for interest groups' activity and their monitoring of EU political developments. The second variable measures the involvement of interest groups in the national EU accession process, and is the sum of the scores (values) that an interest group attributes to the different forms of inclusion in the national EU accession process presented in the descriptive analysis. Third, the variable 'contacts with the EU institutions' is constructed as the sum of the contact frequencies with the European Commission, the European Parliament and the EU regulatory agencies. The fourth column reports the results of a logistic regression analysis performed on the binary variable membership in EU-level associations (no/yes).

The findings suggest that previous accounts of the Europeanisation of national interest groups may apply less to post-communist accession countries than to long-standing EU member states. Notably, the differences between business interests and public interest groups are less pronounced in the former countries. Model 1 confirms (Hypothesis 1 ) that the EU is not more important to business interests than it is to non-governmental organisations. It is even more relevant to 'other groups' than it is to business associations. The second model shows that, surprisingly, business groups are not more involved in domestic accession processes than NGOs. As expected, business groups and NGOs do not vary at all when it comes to the membership in EU associations (Hypothesis 3a) and the establishment of direct contacts with the EU institutions (Hypothesis 3b).

Factors other than the group type seem to matter more when accounting for the differential Europeanisation of groups. In line with previous studies (Beyers and Kerremans 2007; Eising 2004), a policy insider status at the domestic level promotes greater adaptation to the EU, greater involvement in the domestic accession process (Hypothesis 2) as well as a greater amount of contacts with EU institutions. ${ }^{3}$ In addition, resources matter to the adaptation of groups to the EU. The greater their budget, the more they participate in the accession process. A higher number of staff is positively associated with contact frequencies at EU level (Hypothesis 4). Receiving EU funds leads groups to attribute more importance to the EU but does not lead to more contacts with 


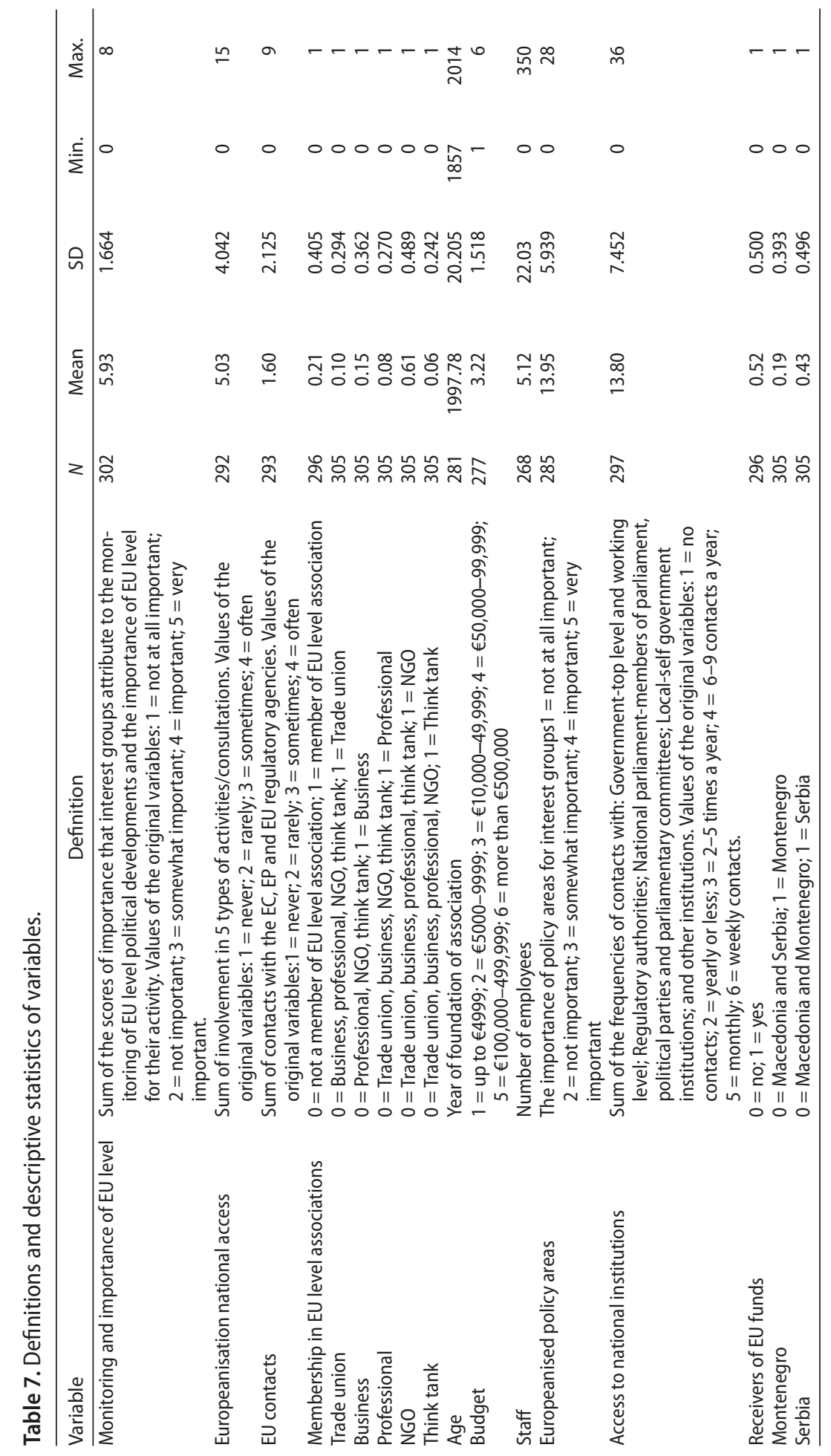


Table 8. Regression analyses on the extent of Europeanisation.

\begin{tabular}{|c|c|c|c|c|}
\hline & $\begin{array}{l}\text { (1) Importance } \\
\text { of EU level }\end{array}$ & $\begin{array}{c}\text { (2) Inclusion } \\
\text { in the national } \\
\text { EU accession } \\
\text { process }\end{array}$ & $\begin{array}{l}\text { (3) Contacts with } \\
\text { EU institutions }\end{array}$ & $\begin{array}{c}\text { (4) Membership } \\
\text { in EU-level asso- } \\
\text { ciations }\end{array}$ \\
\hline Trade union & $\begin{array}{c}0.803 \\
(0.457)\end{array}$ & $\begin{array}{c}0.600 \\
(0.930)\end{array}$ & $\begin{array}{c}0.232 \\
(0.485)\end{array}$ & $\begin{array}{c}0.167 \\
(0.693)\end{array}$ \\
\hline Professional & $\begin{array}{c}0.945 \\
(0.496)\end{array}$ & $\begin{array}{c}0.641 \\
(0.991)\end{array}$ & $\begin{array}{c}0.598 \\
(0.516)\end{array}$ & $\begin{array}{c}0.445 \\
(0.773)\end{array}$ \\
\hline NGO & $\begin{array}{c}0.717 \\
(0.373)\end{array}$ & $\begin{array}{c}0.641 \\
(0.757)\end{array}$ & $\begin{array}{c}0.504 \\
(0.394)\end{array}$ & $\begin{array}{l}-0.389 \\
(0.587)\end{array}$ \\
\hline Other & $\begin{array}{l}1.418^{* *} \\
(0.529)\end{array}$ & $\begin{array}{c}1.231 \\
(1.071)\end{array}$ & $\begin{array}{c}0.747 \\
(0.559)\end{array}$ & $\begin{array}{l}-1.034 \\
(0.951)\end{array}$ \\
\hline Age & $\begin{array}{c}0.005 \\
(0.007)\end{array}$ & $\begin{array}{c}0.004 \\
(0.013)\end{array}$ & $\begin{array}{l}0.018^{* *} \\
(0.007)\end{array}$ & $\begin{array}{l}-0.020 \\
(0.011)\end{array}$ \\
\hline Budget & $\begin{array}{l}-0.023 \\
(0.095)\end{array}$ & $\begin{array}{l}0.508^{* *} \\
(0.192)\end{array}$ & $\begin{array}{c}0.001 \\
(0.100)\end{array}$ & $\begin{array}{c}0.273 \\
(0.159)\end{array}$ \\
\hline Staff & $\begin{array}{l}-0.002 \\
(0.020)\end{array}$ & $\begin{array}{c}0.014 \\
(0.041)\end{array}$ & $\begin{array}{l}0.094^{* *} \\
(0.021)\end{array}$ & $\begin{array}{c}0.004 \\
(0.033)\end{array}$ \\
\hline Policy area & $\begin{array}{l}0.068^{* *} \\
(0.019)\end{array}$ & $\begin{array}{l}0.104^{* *} \\
(0.037)\end{array}$ & $\begin{array}{l}-0.007 \\
(0.019)\end{array}$ & $\begin{array}{c}0.044 \\
(0.032)\end{array}$ \\
\hline $\begin{array}{l}\text { Access to national } \\
\text { institutions }\end{array}$ & $\begin{array}{l}0.071^{* *} \\
(0.015)\end{array}$ & $\begin{array}{l}0.274^{* *} \\
(0.031)\end{array}$ & $\begin{array}{l}0.136^{* *} \\
(0.016)\end{array}$ & $\begin{array}{c}0.032 \\
(0.026)\end{array}$ \\
\hline $\begin{array}{l}\text { Receivers of EU } \\
\text { funds }\end{array}$ & $\begin{array}{l}0.519^{*} \\
(0.256)\end{array}$ & $\begin{array}{c}0.056 \\
(0.513)\end{array}$ & $\begin{array}{c}0.429 \\
(0.267)\end{array}$ & $\begin{array}{c}0.376 \\
(0.429)\end{array}$ \\
\hline Serbia & $\begin{array}{l}-0.222 \\
(0.229)\end{array}$ & $\begin{array}{l}-1.558^{* *} \\
(0.464)\end{array}$ & $\begin{array}{l}-0.799^{* *} \\
(0.241)\end{array}$ & $\begin{array}{l}-0.504 \\
(0.389)\end{array}$ \\
\hline Montenegro & $\begin{array}{l}-0.221 \\
(0.291)\end{array}$ & $\begin{array}{c}-1.785^{* *} \\
(0.587)\end{array}$ & $\begin{array}{c}-0.805^{* *} \\
(0.306)\end{array}$ & $\begin{array}{l}-0.383 \\
(0.448)\end{array}$ \\
\hline $\begin{array}{l}\text { Observations } \\
R^{2} / \text { Nagelkerke } R\end{array}$ & $\begin{array}{c}252 \\
0.235\end{array}$ & $\begin{array}{c}251 \\
0.448\end{array}$ & $\begin{array}{c}252 \\
0.427\end{array}$ & 252 \\
\hline Adjusted R & 0.196 & 0.420 & 0.398 & \\
\hline $\begin{array}{l}\text { F-statistics/Wald } \\
\text { test }\end{array}$ & 6.107 & 16.089 & 14.854 & 71.625 \\
\hline
\end{tabular}

EU institutions. Furthermore, interest groups highly active in policy areas in which the EU has more competencies are also more involved in the domestic accession process and pay more attention to the EU level of governance. But opposite to Hypothesis 5, being active in Europeanised policy areas is not associated with a greater likelihood to be more frequently in touch with EU institutions. Finally, none of the explanatory factors accounted for membership in EU-level associations.

With regard to control variables, older, established associations are more likely to establish direct contacts at EU level. Cross-national differences point to the importance of mobilisation experiences (see also Eising et al., 2017): groups in Macedonia, where the accession process lasts longer than in Serbia and Montenegro, tend to be more involved in domestic consultations and are also more often in contact with EU institutions. 


\section{Conclusions}

I examined the Europeanisation of national interest groups from EU acceding countries. Drawing on insights from the literatures on EU lobbying and postcommunist civil society, I hypothesised that business associations are not more Europeanised than non-governmental organisations in these countries. The empirical analysis of comprehensive survey data on interest groups in Macedonia, Serbia and Montenegro supports this argument. Overall, think tanks and foundations attribute even greater importance to the EU than business associations and are heavily involved in monitoring the EU preaccession process. NGOs do not differ significantly from business interests when it comes to the involvement in the national $\mathrm{EU}$ accession process, to joining EU-level groups, and to the direct lobbying of the European Commission or the European Parliament.

The absence of variation across groups may result from EU conditionality, which, as has been shown elsewhere (Hristova and Cekik 2015), is centred precisely on the involvement of interest groups in the EU accession process, and is potentially more beneficial to NGOs. It may also be a result of the demand for expertise on EU-related issues by political institutions that groups specialising in particular areas might possess (for example environment or consumer policy, in addition to the single market). The time constraints related to the pre-accession process (e.g. the need to provide timely responses to the EC's questionnaire) and the demands related to the transposition of the European legislation might also be strong incentives for governments to open up to their interest environment and benefit from the expertise of various interest groups. This, however, does not necessarily lead to an equal importance of the various types of groups in the long term and may, especially in the cases of NGOs and think tanks, change in the future, once the EU conditionality related to the fulfilment of democratic standards loses its relevance.

The research findings suggest that EU integration reinforces established national patterns. Interest groups that are strong at national level demonstrate a greater capacity to act at the EU level. Indeed, interest groups with a domestic insider status monitor EU politics more intensively, are more involved in the national EU accession process and are also more frequently in touch with EU institutions. The effect of the age of associations is in the same direction: established groups have better chances of becoming multi-level players. The resources of interest groups also matter for their Europeanisation: budget and staff are important for both the involvement in the domestic EU accession process and EU-level activities. All in all, the embeddedness in domestic contexts and the organisational properties of groups seem to be of major importance during the pre-accession process.

At the same time, even though associations receiving EU funding are more likely to assign greater importance to the EU, they are not more likely to get in 
touch with EU institutions. The reason for this is related to what Beyers and Kerremans (2012) call 'critical resource dependencies'. EU funding is more important to small groups, which are less likely to engage in EU-level activity, than to established groups. The latter also secure their funding through other sources (membership fees, most importantly). Similarly, groups active in more Europeanised policy areas tend to attribute a greater importance to EU governance and are more involved in national accession consultations but seem to lack the necessary capacities to engage in direct EU lobbying.

To conclude, the main difference between the highly Europeanised actors in old EU democracies and the accession countries is that in the case of former, these actors are specific business interests (Beyers and Kerremans 2012; Eising 2004), while this does not happen to be the case in post-communist countries. Currently, NGOs and think tanks may possess more knowledge of the EU policy process and have developed the professional lobbying skills suitable for the competitive EU lobbying arena.

\section{Notes}

1. In 2014, interest groups in Montenegro had an average age of 11.5 years. In Macedonia it was 14.5 years and in Serbia it amounted to 19.5 years. Between $20 \%$ and $23 \%$ of the interest groups in these countries were established in the first decade of pluralism (1990-1999), while around half of the respondents are relatively new associations established between 2000 and 2009. In addition, $20.8 \%$ of the associations in Montenegro, $17.6 \%$ of the associations in Macedonia and $12.7 \%$ of the associations in Serbia were only formed in the last four years prior to the research performed for this study (2010 or later). Hence, the interest group populations in these democracies are rather dynamic. The number of organisations which appear and then cease to operate after a short period of time might be rather high.

2. This category is used because of the higher level of professionalisation and knowledge on EU issues that these associations might possess, in comparison to NGOs which typically focus more on advocacy for their membership.

3. To probe whether the variable national access covers potential group type effects, I removed it from the model (not reported). The effects of group type did not change.

\section{Acknowledgements}

This research was conducted during my postdoctoral research stay at the Department of Political Science, University of Salzburg, Austria, under the supervision of Prof. Dr. Andreas Dür, to whom I am thankful for the generous advice and motivation. I would also like to thank the editors of this special issue, especially Rainer Eising, the participants at the workshop for this special issue held on 28 and 29 April 2016 at Ruhr University Bochum, and two anonymous reviewers for very helpful comments on earlier versions of the paper. 


\section{Disclosure statement}

There is no conflict of interest.

\section{Funding}

This research was supported by an Erasmus Mundus SIGMA scholarship [SIGM1200460].

\section{References}

Aspinwall, Mark, and Justin Greenwood, eds. (1998). Collective Action in the European Union: Interests and the New Politics of Associability. London: Routledge.

Balkan Civil Society Development Network (2012). Donors' Strategies and Practices in Civil Society Development in the Balkans. Civil Society Lost in Translation? Skopje: Balkan Civil Society Development Network.

Beyers, Jan (2002). 'Gaining and Seeking Access: The European Adaptation of Domestic Interest Associations', European Journal of Political Research, 41:5, 585-612.

Beyers, Jan, and Bert Kerremans (2007). 'Critical Resource Dependencies and the Europeanization of Domestic Interest Groups', Journal of European Public Policy, $14: 3,460-81$.

Beyers, Jan, and Bert Kerremans (2012). 'Domestic Embeddedness and the Dynamics of Multilevel Venue Shopping in Four EU Member States', Governance: An International Journal of Policy, Administration, and Institutions, 25:2, 263-90.

Blavoukos, Spyros, and George Pagoulatos (2008). 'Enlargement Waves' and Interest Group Participation in the EU Policy-Making System: Establishing a Framework for Analysis', West European Politics, 31:6, 1147-65.

Börzel, Tanja, and Aron Buzogány (2010). 'Governing EU Accession in Transition Countries: The Role of Non-State Actors', Acta Politica, 45:1/2, 158-82.

Bouwen, Peter (2004). 'Exchanging Access Goods for Access: A Comparative Study of Business Lobbying in the European Union Institutions', European Journal of Political Research, 43:3, 337-69.

Carmin, JoAnn (2010). 'NGO Capacity and Environmental Governance in Central and Eastern Europe', Acta Politica, 45:1/2, 183-202.

Císař, Ondřej, and Kateřina Vráblíková (2012). 'Transnational Activism of Social Movement Organizations: The Effect of European Union Funding on Local Groups in the Czech Republic', European Union Politics, 14:1, 140-60.

Fink-Hafner, Danica, Mitja Hafner-Fink, and Meta Novak (2015). 'Europeanization and Interest Group Political-Cultural Change: The Case of Interest Groups in Slovenia', East European Politics and Societies and Cultures, 29:1, 287-305.

Della Porta, Donatella, and Manuela Caiani (2007). 'Europeanization from below? Social Movements and Europe', Mobilization: An International Quarterly, 12:1, 1-20. 
Dür, Andreas, and Gemma Mateo (2016). Insiders versus Outsiders. Interest Group Politics in Multilevel Europe. Oxford: Oxford University Press.

Dür, Andreas, Patrick Bernhagen, and David Marshall (2015). 'Interest Group Success in the European Union: When (and Why) Does Business Lose?', Comparative Political Studies, 48:8, 951-83.

Eising, Rainer (2004). 'Multilevel Governance and Business Interests in the European Union', Governance: An International Journal of Policy, Administration and Institutions, $17: 2,211-45$.

Eising, Rainer (2007). 'Institutional Context, Organizational Resources and Strategic Choices: Explaining Interest Groups Access to the European Union', European Union Politics, 8:3, 329-62.

Eising, Rainer (2017). 'Imperfect Public Goods and the Logic of Selective Exit in EU Interest Organizations', West European Politics, doi: 10.1080/01402382.2017.1320173

Eising, Rainer, Daniel Rasch, Patrycja Rozbicka, Danica Fink-Hafner, Mitja Hafner-Fink, and Meta Novak (2017). 'Who Says What to Whom? Alignments and Arguments in EU Policy Making', West European Politics, doi: 10.1080/01402382.2017.1320175

Fagan, Adam (2010). 'The New Kids on the Block- Building Environmental Governance in the Western Balkans', Acta Politica, 45:1/2, 203-28.

Falkner, Gerda (2000). 'Policy Networks in a Multi-Level System: Convergence towards Moderate Diversity?', West European Politics, 23:4, 94-120.

Fink-Hafner, Danica (1998). 'Organized Interests in the Policy-Making Process in Slovenia', Journal of European Public Policy, 5:2, 285-302.

Grosse, Tomasz G. (2010). 'Social Dialogue during Enlargement: The Case of Poland and Estonia', Acta Politica, 45:1-2, 112-35.

Hristova, Lidija, and Aneta Cekik (2015). "the Europeanization of Interest Groups: EU Conditionality and Adaptation of Interest Groups to the EU Accession Process in the R. Macedonia, East European Politics, 31:1, 23-38.

Klüver, Heike (2010). 'Europeanization of Lobbying Activities: When National Interest Groups Spill over to the European Level', Journal of European Integration, 32:2, 17591.

Kohler-Koch, Beate, Peter Kotzian, and Christine Quittkat (2017). 'The Multi-Level Interest Representation of National Business Associations,' West European Politics, doi: 10.1080/01402382.2017.1303244

Komar, Olivera (2015). 'The Development of Civil Society in Montenegro', in Danica Fink-Hafner (ed.), The Development of Civil Society in the Countries on the Territory of the Former Yugoslavia since the 1980s. Ljubljana: Faculty of Social Sciences, University of Ljubljana, 145-64.

Koutalakis, Charalambos (2010). 'Enabling Harmonization - Business Actors and the Eastern Enlargement of the EU', Acta Politica, 45:1/2, 247-67.

Mahoney, Christine (2004). 'The Power of Institutions: State and Interest Group Activity in the European Union', European Union Politics, 5:4, 441-66.

Mansfredova, Zdenka (2007). 'Czech Trade Unions and Employers' Associations in the European Social Dialogue, in Daniela Obradovic and Heiko Pleines (eds.), The Capacity of Central East European Interest Groups to Participate in EU Governance. Stuttgart: ibidem-Verlag, 213-30.

Mazey, Sonia, and Jeremy Richardson, eds. (1993). Lobbying in the European Community. Oxford: Oxford University Press.

Obradovic, Daniela, and Redmar Damsma (2007). 'Central and Eastern European Civil Society as a Constituency in the Commissions' Consultations', in Daniela Obradovic and Heiko Pleines (eds.), The Capacity of Central East European Interest Groups to Participate in EU Governance. Stuttgart: ibidem-Verlag, 127-49. 
Pérez-Solórzano Borragán, Nieves (2001). 'Organized interest in Central and Eastern Europe. Towards Gradual Europeanisation?', Politique européene, 3, 61-87.

Pérez-Solórzano Borragán, Nieves (2006). 'Post-Communist Interest Politics: A Research Agenda', Perspectives on European Politics and Society, 7:2, 134-54.

Pérez-Solórzano Borragán, Nieves, and Stijn Smismans (2012). 'The EU's Promotion of Social Dialogue in the New Member States', in Stijn Smismans (ed.), The European Union and Industrial Relations. Manchester, NH: Manchester University Press, 116-38.

Pleines, Heiko (2010). "Is this the Way to Brussels? CEE Civil Society Involvement in EU Governance', Acta Politica, 45:1/2, 229-46.

Sallai, Dorottya (2013). 'European Union Lobbying and the Golden Cage of PostSocialist Network Capitalism in Hungary', Journal of Common Market Studies, 51:5, 948-64.

Saurugger, Sabine (2005). 'Europeanization as a Methodological Challenge: The Case of Interest Groups', Journal of Comparative Policy Analysis: Research and Practice, $7: 4,291-312$.

Sudbery, Imogen (2010). 'The European Union as a Political Resource: NGOs as Change Agents?', Acta Politica, 45:1/2, 136-57.

Uhlin, Anders (2006). Post-Soviet Civil Society: Democratisation in Russia and the Baltic States. London: Routledge. 


\title{
Networkers, fund hunters, intermediaries, or policy players? The activities of regions in Brussels
}

\author{
Michaël Tatham
}

\begin{abstract}
Regions started opening offices in Brussels in the mid-1980s. Today, well over half of Europe's regions are present there. What do they do once they are in Brussels? Are they mainly networking, chasing funding, acting as intermediaries, monitoring legislation, or trying to influence the EU's decision-making process? No study has analysed this question apart from the pioneering work by Marks et al. in 2002. This article breaks new ground by analysing both group-level and contextual factors in a series of multilevel models. Based on a survey of regional offices in Brussels, results indicate that contextual factors, such as levels of self-government back home, matter. However, group-level characteristics, such as an office's longevity in Brussels, seem to affect a wider range of activities. Overall, older offices are more interested in the EU policy-making process and less interested in chasing funds or networking. Conversely, offices representing regions with weaker self-governing capacities rather conceive of their role as that of an intermediary, acting as an interface between the region and the EU institutions.
\end{abstract}

As European integration has deepened, the incentives for interest groups to mobilise at the supranational level have increased. This has led to a steady growth in the Europeanisation of interest groups. Such Europeanisation has been visible both at home, in terms of internal structures such as having an EU affairs division, but also in Brussels, in terms of presence in the European capital, ranging from short visits and ad hoc meetings to opening an office directly at the heart of the EU. In other words, not only is the diversity of such groups increasing but the depth and width of their involvement has also grown (Greenwood 2011).

The expanding nature of this supranational mobilisation has encouraged researchers to study how and under what circumstances these actors mobilise (Bernhagen and Mitchell 2009; Dür and Mateo 2012), via what channels 
and through what access points (Eising 2007; Kriesi et al. 2007), and by what strategies (Beyers 2004; Dür and Mateo 2013). This research has highlighted a diversity of patterns driven by various group-specific as well as contextual factors (Beyers et al. 2008; Eising 2017; Eising et al. 2017).

Wishing to further explore the effects of both actor-specific and contextual factors, this article seeks to deepen our knowledge in two areas often neglected by the mainstream EU interest representation literature. First, while the current literature has produced robust findings on a series of multilevel interest representation patterns, it has often focused on activities related to one type of objective: achieving policy influence. This has been to the detriment of other activities such as funds-hunting or networking, which may or may not be related to influence-seeking. Second, while there is much knowledge regarding the determinants of mobilisation by different types of groups, ranging from businesses to trade unions, one type of interest group has received comparatively less attention from the EU interest representation literature: regions.

This article seeks to increase our knowledge at the intersection of those two research areas. It does so by analysing the factors which affect the decision of regional offices in Brussels to focus on some activities (such as hunting for funds) to the detriment of others (such as networking). Using original survey data containing information on over 100 regional offices, it identifies five types of activities. It finds that these are varyingly prioritised. Policy influence and funds hunting come across as the most popular, followed by legislative information-gathering and networking activities, and finally adopting a more passive role as a facilitating interface between the region itself and the EU institutions. The prioritisation of these activities over one another is differently affected by office resources and by the region's domestic institutional and partypolitical contexts. It is unaffected by party-political configurations back home. It is to some extent affected by the domestic distribution of powers, but to a lesser extent than expected from the literature. It is mostly affected by the length of presence of the region in Brussels. Indeed, the greater the office's longevity, the greater the likelihood that it will seek to influence the EU's decision-making and to gain information about upcoming EU legislation relevant to its region. Greater longevity in Brussels implies that other activities consequently fall down the pecking order, such as funds-chasing or networking with other subnational representations. In sum, this article emphasises the importance of experience and longevity in the Brussels pond to better understand the activities that representational offices undertake.

\section{What to do in Brussels? Five types of activities}

Interest groups of all kinds have increased their mobilisation in Brussels over time. This is the result of the EU's development in terms of the funding opportunities it provides and of its regulatory reach. This mobilisation has taken 
different forms, such as setting up meetings with Commission officials, anonymously briefing members of the European Parliament (MEPs) on policy drafts, joining pan-European associations, hiring intermediaries (such as consultants, law firms, or professional lobbyists) to carry out representational tasks, or more simply setting up an internal EU affairs division. One of the more remarkable forms of mobilisation has been to open an office directly in Brussels. This is indeed one of the costliest mobilisation activities. It tends to co-vary with other activities such as registering on the European Parliament (EP) lobbyist registry or having an EU division back home (Bernhagen and Mitchell 2009: 168). Estimates of the total number of representational offices in Brussels fluctuate. For example, in 2003 Greenwood counted 1627 offices, rising to 2169 in 2011, and each time including a variety of groups from companies, consultancies, law firms, trade/professional associations, citizen associations, think tanks, or regions (Greenwood 2003: 9; 2011: 14).

However, not all offices carry out the same tasks. I argue that at least five types of activities can be of interest. Whilst some offices will clearly focus on lobbying activities understood as attempts to influence the EU's decisionmaking process in one's favour (1), other offices will focus on different activities than 'hard' lobbying. These may include gaining information on upcoming and relevant legislation (2). This is a proactive type of activity with a legislative dimension but with an emphasis on information-gathering. It might be undertaken as preparatory work for forthcoming lobbying activities, but it may also be geared towards preparing for future challenges related to implementation or organisational adaptation. A third type of activity is related to increasing chances of funding by gaining privileged information about such financial opportunities (3). This funding may be aimed at co-financing public policies or projects. It may also be aimed at helping private firms within the region, for example as a way of subsidising research and development. A fourth type of activity is more passive, with the office acting as an intermediary or liaison between its group constituents and EU institutions (4). For example, a corporate office may act as an interface for different divisions within the mother company and EU institutions. Similarly, a regional office may act as a platform facilitating exchange between regional stakeholders on the one hand, and the EP, the Commission, and the EU's various agencies on the other. Finally, a fifth type of activity may have to do with networking, understood as building ties with other offices (5). This networking activity may be conceived as serving information-gathering activities (of a funding or regulatory nature) or as a coalition-building exercise in view of future lobbying activities. Or it may be geared towards best practice exchange and the setting up of bi/multilateral joint ventures. Hence, at least five types of activities can be identified which, though distinct, are by no means mutually exclusive.

As indicated above, a variety of groups ranging from corporations, labour unions, and employers' federations have opened such offices. Among those 
groups are regional authorities. Regions have mobilised in Brussels since the mid-1980s. There is much knowledge on this mobilisation drive, especially in terms of the determinants of mobilisation itself (Marks et al. 1996; Tatham and Thau 2014), the forms of such mobilisation (Donas and Beyers 2013), the channels of mobilisation (Bomberg and Peterson 1998; Tatham 2008), or the interaction patterns and strategies generated by such mobilisation (Beyers and Donas 2014; Tatham 2016). However, just as for other EU stakeholders, there is relatively little knowledge on the determinants of the different activities regions decide to undertake once they set foot in the Brussels microcosm.

To gain greater insights into the drivers of the different Brussels-based activities of regional offices, this research builds on the two existing studies which have previously made inroads into this subject. The first is the ground-breaking study by Marks et al. (2002). This study identified 10 types of activities and argued that they clustered into three meta-types: 'exerting influence,' 'liaising,' and 'networking/information-gathering. This seminal publication was innovative in terms of data, methods, and insights into the world of Brussels offices. However, it provides an incomplete picture. Indeed, it generated much knowledge about the drivers of influence, but was less interested in accounting for variation in other types of activities. Similarly, its structural equation modelling approach focused on relations within a specified causal chain which does not allow an assessment of how these relations behave in a fully multivariate environment. Finally, the study's data date from 1999. This was a very different EU environment. The Union counted only 15 member states, was in the course of implementing the reforms ratified in the Amsterdam Treaty and had yet to experience preparations for the Nice Treaty (2003), and the signed but never ratified Treaty establishing a Constitution for Europe (2004), which was finally implemented in all but name ${ }^{1}$ in the Lisbon Treaty (2009).

The second study is a re-run of the Marks et al. (2002) survey by Mbaye (2009). Relying on 2008 data, her analysis provides a glimpse into the postenlargement EU27, in the transition from the Constitutional Treaty to the Lisbon Treaty. It therefore provides an up-to-date view of the EU as we know it today. However, her study's main value-added also represents its biggest drawback. By replicating the Marks et al. (2002) study it fell victim to the offices' changing role. Whilst the Brussels offices of the late 1990s seemed to perceive different activities with different levels of importance, the offices of the late 2000s are either unwilling to reveal that they perceive some activities as less important than others, or have become more generalist over time as a result of the expansion of the EU's competences. Hence, instead of activities neatly clustering into different types, her analysis reveals little variation among offices over the 14 types of activities proposed. This results in most variance being captured by a 'generalist' profile: offices claim that almost all of their possible activities are of prime importance. This lack of variation implies that it is then next to impossible to determine why certain offices focus on certain 
activities and not others. As Mbaye (2009: 13) indicates, 'the offices all seem to think they're doing nearly everything?.

If one is to accept the claim that 'offices in 2008 tend to believe that they are pursuing many activities simultaneously' (Mbaye 2009: 10), the interesting question to ask then shifts in nature. It is no longer informative to enquire about what activities are perceived as important in absolute terms as the answer - as experienced by Mbaye (2009: 13) - will be 'nearly everything'. It then becomes much more interesting to enquire about the rank-ordering of these activities in other words, to enquire about the importance of each activity in relative terms, compared to other activities. The research question hence shifts from learning what offices perceive as important, to learning why offices prioritise certain activities over others. The following section highlights three explanatory approaches which might shed some light on the drivers of differential rankorderings of activities.

\section{Resources, institutions, and partisanship}

Both the interest representation literature and the territorial politics literature have highlighted the role played by two types of factors. The first concerns group-level characteristics; the second concerns environmental or contextual factors. Clearly, in some cases these are mutually influential. However, the distinction between the two is analytically useful, as some group characteristics can be altered, whilst some contextual factors are rather harder to change. To gain a better understanding of why certain offices may prioritise some activities over others, I test for three types of explanations which have to do with the office's resources, the region's domestic institutional context, and finally its partisan context.

The first explanation deals with office-level resources. An office's resources will play a key role in determining its capacity and also its interest in undertaking more or less challenging activities. Indeed, some activities require a greater capacity in terms of material resources, but also in terms of expertise or knowledge. I distinguish between two types of resources. The first is material resources, as crystallised by larger operational budgets or a bigger pool of staff. The second type, non-material resources, covers experience and know-how. I expect that the greater an office's resources, the greater its capacity to engage in more costly activities such as seeking to influence the EU decision-making process or tracking upcoming legislative developments whilst those are still in the pipeline (Dür and Mateo 2012: 971-2; Klüver 2012: 505; Marks et al. 2002: 12). This implies that offices with weaker resources will be more likely to prioritise less costly activities such as funds-chasing, networking, or the more passive role of acting as an interface between domestic stakeholders and EU institutions. 
Hypothesis 1: The greater the office's resources, the more it will prioritise policy influence and legislative monitoring over other activities.

The second explanation has to do with the region's domestic institutional context. Brussels offices represent stakeholders that are domestically embedded. The same goes for regional offices in Brussels: the institutional context in which their 'home' region is embedded may affect the role and activities that the office takes on. The interest group literature has focused on different types of domestic institutional contexts, such as the tension between corporatist, pluralist, statist, clientelist, or consociational systems (e.g. Binderkrantz and Rasmussen 2015: 555-6). When it comes to regions and their interaction with the EU level, the relevant dimensions of the institutional context have to do with (1) the extent of self-government of the region in the domestic polity, and (2) to what extent it can shape its parent state's position on EU affairs.

The degree to which the region has self-government authority within the domestic polity shapes its regulatory exposure to the EU political system. Indeed, Marks et al. (1996: 170) have argued that 'the larger the scope of political autonomy of a subnational government, the more it will seek information concerning policy developments in the European pipeline and the more it will wish to express its interests there. The effect of domestic self-government on the behaviour of the offices in Brussels has been documented (Donas and Beyers 2013: 541; Tatham 2016: 238-51) but has not been explored when it comes to the actual prioritisation of activities in Brussels. However, the literature tends to associate higher levels of self-government with a greater interest in the EU's legislative activities and a desire to achieve policy influence (Callanan and Tatham 2014: 198-200; Tatham 2008: 506-8).

The extent to which the region has leverage on its member state in EU affairs may well have the reverse effect, however. Indeed, having secured a degree of influence over EU affairs domestically, via its member state, the region will have less of an incentive to invest heavily in lobbying and legislative activities in Brussels, where it has to compete with a myriad of other stakeholders. Domestic influence through intra-state channels (Bomberg and Peterson 1998: 231; Jeffery 2000: 14) implies that the region can then prioritise other activities when it engages in extra-state mobilisation. Hence, intra-state influence would lead to a different division of labour between the region's home administration and its antenna in Brussels, and thus a different rank-ordering of activities by the latter.

Hypothesis 2a: The greater the region's level of self-government, the more its Brussels office will prioritise policy influence and legislative monitoring over other activities.

Hypothesis 2b: The greater the region's domestic leverage on EU affairs, the less its Brussels office will prioritise policy influence and legislative monitoring over other activities. 
The third contextual explanation concerns domestic party-political constellations. Similarly to the institutional expectation above, it taps into the idea that a group's domestic opportunity structure will affect whether, how, and for what purposes it mobilises supranationally. Whereas the above explanation focuses on institutional determinants which affect the extent to which the region is exposed to the EU's regulatory reach (H2a) and the extent to which domestic channels are more efficient than supranational channels (H2b), this explanation focuses on partisanship. Party-political incongruence, here understood as government of the region by a party in opposition to central government, may lead to the domestic exclusion of its interests and hence loss of access to intra-state channels. This process has been well documented in the territorial politics literature (Marks 1996: 411-12; for an overview see Tatham 2016: 24-6) and increasingly in the interest representation literature (Eising et al. 2017; Rasmussen 2012; Rasmussen and Lindeboom 2013; Wonka 2017). One can therefore expect that, as intra-state channels are closed down, groups need to find alternative routes into the supranational decision-making process. Hence, party-political incongruence will lead to greater supranational mobilisation on policy and legislative issues, so as to compensate for their domestic blockade.

Hypothesis 3: If the region is governed by an opposition party to central government, its Brussels office will prioritise policy influence and legislative monitoring over other activities.

There are many other possible factors which may affect how regional offices situate different activities further up or down their list of priorities. However, focusing on office-level resources, as well as the domestic institutional and partisan contexts, provides a first cut towards a better understanding of offices' prioritisation logics. I nonetheless control for a series of factors which may also play a role. This is because all of these factors have been shown to affect other dimensions of regional mobilisation to the supranational level, such as opening an office, having a bigger rather than smaller office, or focusing on certain policy domains (e.g. economic vs cultural activities). First, I control for a region's absolute size (Nielsen and Salk 1998). Second, I control for the level of economic development of the region (Marks et al. 1996). Third, I control for a region's demographic make-up in terms of how densely or sparsely populated it is (Tatham and Thau 2014). Finally, I control for the possibility that a region may be distinctive in cultural or identity terms (Blatter et al. 2009). All of these factors help to better model the bewildering heterogeneity of the population of European regions. These regions range from the small (e.g. the German community in Belgium) to the big (e.g. North Rhine-Westphalia), from the less economically developed (e.g. Județ Vrancea) to the wealthier (e.g. région Îlede-France), from the more rural (e.g. Lapland) to the more urban (e.g. région de Bruxelles-Capitale), and include areas which are highly distinctive within their embedding state (e.g. Northern Ireland, Basque Country, or Sardegna). 


\section{Data and methods}

There is no official repository of the activities of regional representations in Brussels. To collect information on these activities, I conducted an online survey. The survey ran for a period of 13 months between 2008 and 2009, and was accessible through personalised, individual, password-protected links. It was sent to 217 heads of office in Brussels (i.e. estimated population). Over $52 \%$ logged in the survey (i.e. 114) and over $49 \%$ responded fully (i.e. 107). Four cases, however, had to be dropped because of missing data on non-survey variables, hence corresponding to a sample of 103 complete observations, representing about $47 \%$ of the estimated population. Table S1 in the online supplemental material displays a list of the surveyed offices.

Offices from 20 countries participated in the survey. On average, about five offices from each country participated. The seven countries which are not included in the sample are Bulgaria, Cyprus, Estonia, Greece, Luxembourg, Malta, and Slovenia. All these countries are rather small, often do not have a regional level (Cyprus, Malta, or Luxembourg), or only have very few or no offices at all in Brussels (Bulgaria, Estonia, Greece, or Slovenia).

As participation in the survey is voluntary, it is possible that it suffers from a self-selection bias. To assess to what extent the sample may be biased, the survey data were compared to population data. There are few datasets available covering the population of regional offices in Brussels. Tatham and Thau (2014) provide a point of comparison. Their study is different from this one, as they use a narrower definition of a region, understood as the level of government and/or administration situated immediately below the state (thus excluding the lower tier in countries where there are two regional tiers). They find that 156 regions out of 233 'upper tier' regions have an office in Brussels. These 156 offices hence represent population data for these regions. As Table S2 in the online supplemental material illustrates, deviations between the present survey data and the 2012 population data are minimal.

It is through this survey instrument that questions were asked about the importance of different activities. Following the seminal work carried out by Marks et al. (2002), I reproduced a number of questions from their original questionnaire about the importance of different activities. However, instead of grading the importance of each activity on a scale ranging from 1 (not at all important) to 5 (very important), I asked the head of each office to select which activity is the most important, second most important, third most important, fourth most important, and fifth most important. The rationale behind such forced ranking is to avoid respondents rating all activities as tremendously important, with scores varying between 4 and 5 .

Indeed, whilst offices surveyed in the late 1990s tended to carry out a more limited range of activities, current offices in Brussels tend to adopt a more generalist profile (Mbaye 2009). This may be the result of deeper European 
integration: with the Union's deepening, regional offices have had to widen the scope of their activities and embrace a broader, more encompassing profile. However, this may also be the consequence of (1) strategic signalling by office heads who may wish to communicate that their office treats all possible activities as very important and/or (2) wishful thinking by office heads, who would ideally like to treat all activities as highly important. Whatever the reason, be it a result of the natural evolution of offices or of strategic signalling/wishful thinking, simply enquiring about the importance of different activities has proved increasingly unfruitful.

Rather than evaluating the 'importance' of each activity in absolute terms, a more informative way to collect data on offices' activities is to ask them to rank these activities in relative terms. Forcing respondents to choose their most important activity followed by their second, third, etc. certainly introduces artificial variance. For example, the top two priorities might be tightly clustered together while the third and fourth might also be hanging more closely together than their ranking would suggest. However, these answer categories also force respondents (i.e. heads of offices) to make difficult prioritisation decisions with regard to the activities of their office. These are the same difficult prioritisation decisions that they have to make on a daily basis in the distribution and rankordering of the workload in their team. Such a ranking procedure might therefore depict office priorities more accurately than their non-mutuallyexclusive grading would. In sum, rank-ordering rather than scoring activities is a different question altogether. The latter enquires about absolute importance, the former about the relative importance of each activity compared to the other available activities.

Consequently, the survey enquired about nine activities overall, borrowed from Marks et al. (2002). ${ }^{2}$ It asked heads of offices 'which of the following nine activities are the most important in your office's work' from the 'most important activity' to the 'fifth most important activity'. Out of those nine activities, five were then selected for analysis due to their central importance in the literature. ${ }^{3}$ These five activities deal with policy influence ('To influence decision-making in the EU in favour of your region'), legislative information-gathering ('To gain information about upcoming EU legislation relevant to your region'), funds-hunting ('To gain information about funding opportunities for your region'), liaison activities ('To act as liaison between groups in your region and EU institutions'), and networking ('To build ties with other regional or local representations'). The data were then recoded to obtain the rank of each activity for each office on an ordinal scale (5-0) where higher values reflect a higher rank.

It is also through this survey instrument that data was collected on offices' resources in Brussels. To measure material resources, the survey enquired about the office's full-time staff. This excludes part-time staff, which is by definition more unstable and often includes short-term interns, stagiaires, or job-sharing 
support staff (e.g. secretarial and IT personnel). The focus on staff numbers is due to the fact that this variable usually correlates highly with budget. Whilst offices are reluctant to disclose their budget, they are usually willing to reveal their number of employees (e.g. Klüver 2012: 500). To measure non-material resources related to experience and know-how, the survey asked about the office's opening date. Case study evidence suggests that older offices are more embedded and have, over time, managed to strengthen and entrench their presence in the European capital (Moore 2008b: 517), thereby accumulating experience and social capital in the Brussels microcosm.

Party-political incongruence was measured in two ways via the survey instrument. First by identifying whether the region is indeed governed by 'the main state-wide opposition party' ( $=1$, otherwise 0$)$. Second by identifying whether it is governed by 'a nationalist or regionalist party' (=1, otherwise 0$)$. The nationalist/regionalist dimension is useful in terms of capturing possible ideological or preference incongruence which may in turn affect the domestic opportunity structure in the same way as government by the opposition party would.

Finally, the domestic institutional context was measured in two ways, so as to reflect the countervailing pressures it may generate on the use of intrastate and extra-state channels. Self-government is measured through Hooghe et al's (2016) updated measure of 'self-rule', which includes five dimensions: a region's institutional depth, policy scope, fiscal autonomy, borrowing autonomy, and representation. The regions' domestic leverage on EU affairs is measured through Tatham's (2011) measure of 'institutionalised regional involvement in the domestic EU policy-shaping process' which includes eight indicators related to the pre-legislative, legislative, and post-legislative involvement of regions in terms of extent, legal basis, and bindingness. ${ }^{4}$

Regarding the control variables, regional size was measured through demographic weight (i.e. population levels). Consistently with past analyses, regional economic development was operationalised via a gross domestic product per capita measure (Donas and Beyers 2013; Nielsen and Salk 1998). Data for these indicators as well as a measure of population density was made available by Eurostat. Finally, regional distinctiveness was measured thanks to typologies carefully created and documented by Brigevich (2012).

Information on all the variables with regard to data sources and descriptive statistics is summarised in Table 1. These data are analysed using multilevel ordered logit models. Multilevel models are used to factor in any residual cross-national variation, whilst ordered models are used because the ordinal nature of the data does not allow the assumption of equal distance between each point along the scale (i.e. they cannot be expressed on an interval scale, see above discussion). 


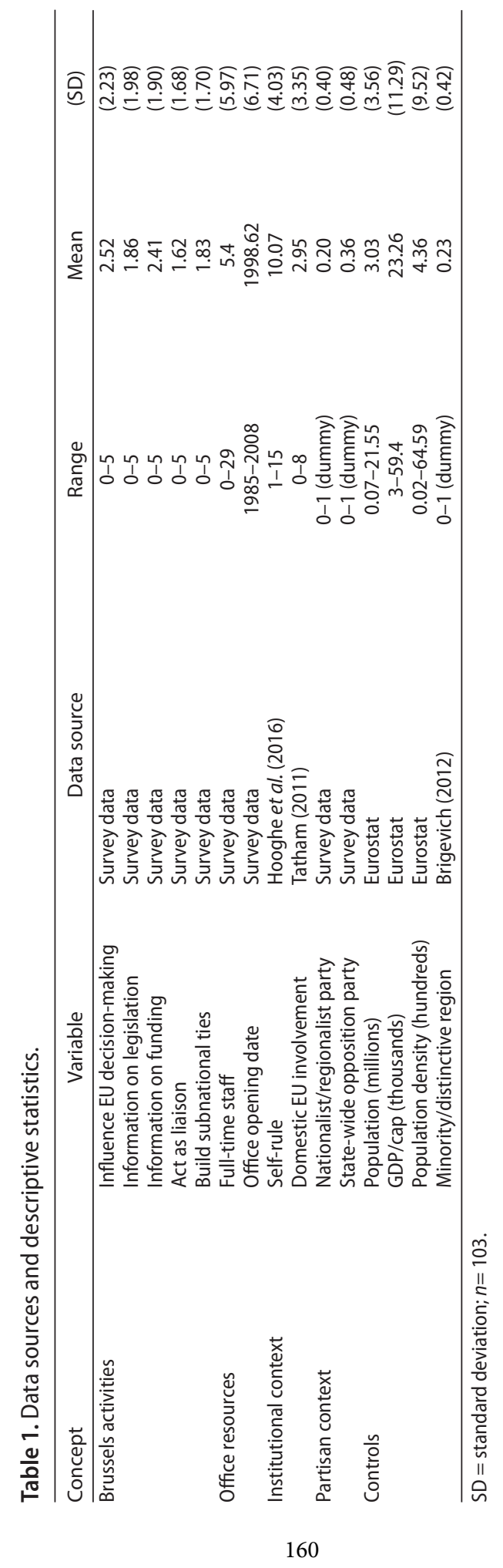




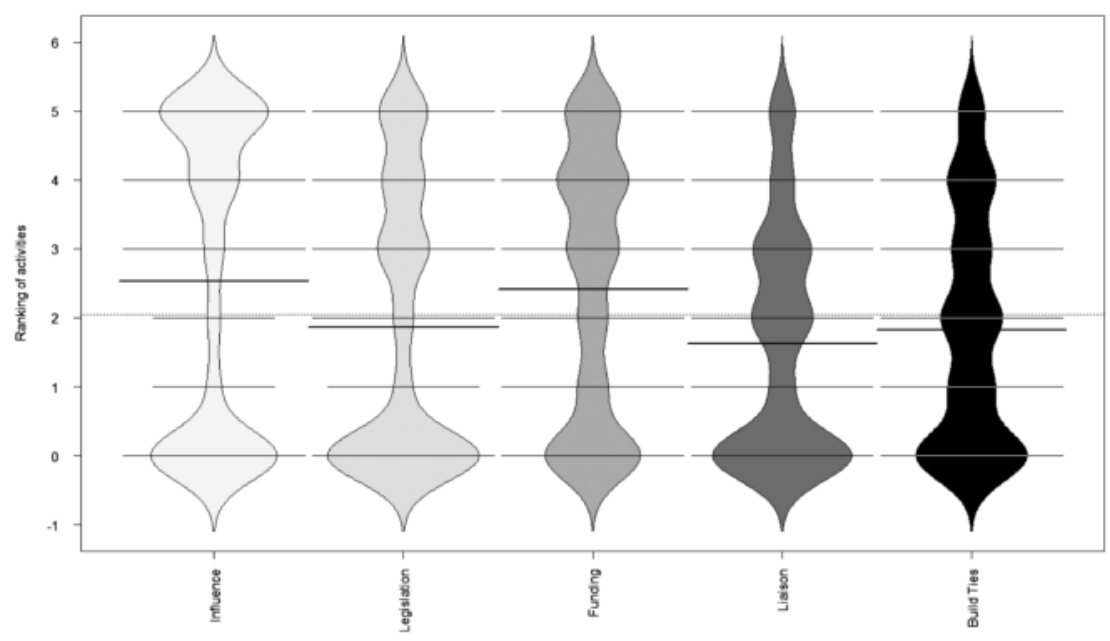

Figure 1. Regional office activities.

Notes: Bean plots with density trace of the ranking of different activities carried out by regional offices in terms of their importance from the most important activity $(=5)$ to the least important $(=0)$. Thick line $=$ mean, dotted line $=$ overall average.

\section{New kids on the block: the importance of Brussels-based experience}

The data presented in Table 1 is further summarised in Figures 1 and 2. Figure 1 presents bean plots with a density trace - in other words, a combination of a boxplot and a histogram. Figure 2 presents a correlation and scatter plot matrix detailing the bivariate relations between the dependent and explanatory variables. These data are already highly informative. On average, influence and funds-chasing are the most prioritised activities. They are followed by legislative information and networking among offices. Liaison activities are least popular. What is even more striking is that, as depicted in Figure 1, influence seems to be an 'either/or' type of activity. Either offices are interested in influence and they rank it highly, or they are not interested in influence and they rank it very low on their list of priorities. This is why the influence measure mostly consists of two distinctive bulges: one at values of five (i.e. the most important activity) and another at values of zero (i.e. activity ranked sixth or lower). To some extent the same applies to legislative information, which consists of a bulging zero category, thin one and two categories, and thicker three, four, and five categories. In other words, offices rank influence and legislative activities either very highly or very low. Hence these two activities come across as distinct from funds-chasing, liaison, or networking which exhibit a less polarised spread.

This interpretation of the data is reinforced when inspecting the matrix in Figure 2. Influence and legislative information are positively related $(r=$ $0.30, p \leq 0.002)$. However, both of these activities are systematically negatively 




Figure 2. Correlation and scatter plot matrix.

Notes: Bivariate scatter plots with confidence ellipses below the diagonal, histograms on the diagonal, and Pearson correlations above the diagonal.' $n b \_E m p '=$ number of full-time employees, ${ }^{\prime} N a t \_R e g '=$ government by a nationalist or regionalist party.

associated with funds-chasing $(r=-0.27, p \leq 0.006$ and $r=-0.37, p \leq 0.0001)$, liaison $(r=-0.34, p \leq 0.0004$ and $r=-0.21, p \leq 0.04)$, or networking $(r=-0.53$, $p \leq 0.0001$ and $r=-0.25, p \leq 0.02$ ). Meanwhile, these last three activities (funding, liaison, and networking) hardly correlate with one another, hence indicating that they are not polarising activities. The take-home message is that focusing on influence and legislative activities generates a systematic neglect of the other activities. This echoes past findings which have argued in favour of a simplified understanding of regional offices, distinguishing those interested in legislative influence as opposed to all the others (Callanan and Tatham 2014: 191-3; Tatham 2008: 506-8).

Figure 2 also provides some support for the resource and institutional context explanations, but suggests a rather trivial effect for partisan incongruence. Indeed, none of the two partisan variables relate significantly to the ranking of any of the activities. However, there is much bivariate support for 
the resource and institutional context variables. Offices with greater staff and longer experience in Brussels are significantly more interested in influence and legislation, and significantly less interested in funding or networking. However, these resources fail to affect the ranking of liaison activities. Similarly, self-rule and EU leverage are (either both or individually) positively associated with influence and legislative activities and negatively related to funding, liaison, and networking. These bivariate findings mirror those of case studies which have suggested linkages between these various factors (Bomberg and Peterson 1998; Jeffery 2000; Moore 2008b; Tatham 2008).

Most of these relations, however, do not survive the multivariate test of the multilevel ordered logit analysis presented in Table 2. First, the effect of the 'home' institutional context on office activities becomes much less pronounced. In the more controlled setting of the full models, self-rule fails to affect funds-hunting and networking. Consistent with theoretical expectations, greater self-rule does lead to the prioritisation of influence-seeking and legislative information. Each time a one-unit increase of self-rule increases the odds of prioritising influence or legislative monitoring by $17 \%$ and decreases those of liaison activities by $16 \%$. Following our theoretical expectations, domestic EU leverage has the contrary effect: every additional unit decreases the odds of influence-seeking by $16 \%$ and increases those of liaison activities by $13 \%$ (although this last result is not statistically significant). The contrasting effects of self-government and EU leverage - the one increasing incentives to invest in costly extra-state activities, the other decreasing such incentives - is all the more striking as these two variables are highly related. In other words, despite their positive correlation (self-rule and domestic leverage on EU issues tend to go hand-in-hand), they have opposite effects. ${ }^{5}$

Although the effect of material and non-material resources tend to go in the same direction, the staff resources indicator never achieves statistical significance. The length of experience in Brussels, however, affects all activities bar that of liaison. With each additional year of experience in Brussels, an office will prioritise influence and legislative information by $7 \%$ and $10 \%$ and will be likelier to neglect funds-chasing and networking by $10 \%$ and $8 \%$. These findings reinforce those of qualitative case study research which had highlighted the length of experience in Brussels as a key variable affecting regional behaviour in the EU capital.

For example, in her study of Polish and Czech regional offices, Moore (2008a) highlights how new regional entrants in the Brussels world tend to put greater emphasis on funds-hunting and networking. According to her, they are understandably concerned with 'the aim of securing favourable recognition in programming documentation for structural funds' and this becomes an explicitly 'articulated objective' (Moore 2008a: 224). Meanwhile, their emphasis on networking activities is driven by a desire to maximise the 'exchange of best practice in regional representation and [to] foster social learning among' 


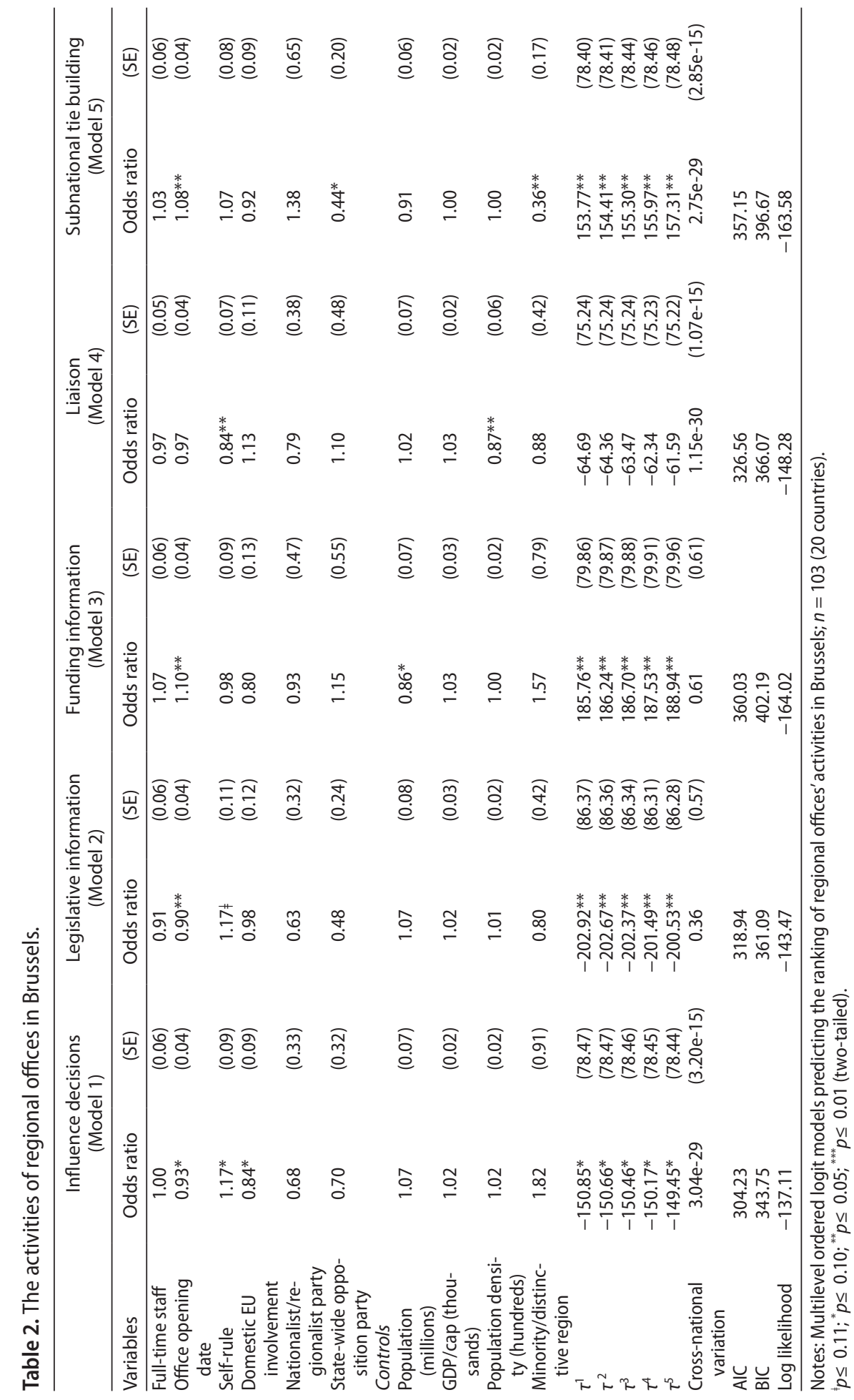


themselves (Moore, 2008a: 224). Moore (2008a: 225) had already highlighted that these are also 'familiar concerns' for regional representations from 'old' Europe, hence underlining that this is not a reflection of an 'old' vs 'new' member state cleavage ${ }^{6}$ or an artefact of the date at which the region joined the EU itself.7 The drivers were rather perceived as related to lower economic development (GDP/capita), weaker institutional status back home (e.g. self-rule or domestic leverage on EU issues), and poor staffing in Brussels. This research, however, shows that, controlling for all of these factors, the length of experience in Brussels has a direct and independent effect on the prioritisation of activities geared towards influence, legislation, funding, and networking. Hence, older offices with greater experience of the Brussels world will be more likely to focus on the demanding tasks of policy influence and legislative monitoring, but will have less of an interest in hunting for funds and less of a need (due to their already larger know-how and Brussels-based social capital) to engage in networking activities.

\section{Conclusion}

In this article I have sought to answer some of the key questions raised by the special issue in terms of the relevance of individual- and contextual-level explanations of interest representation patterns in the EU's multi-tier system. To do this, I have focused on a group of actors commonly overlooked by the mainstream interest representation literature: regions. Regions, like many other domestic actors, mobilise to the supranational level through a variety of channels and instruments. One of those consists of opening an office directly at the heart of Europe. Similarly to other interest groups, such as firms, professional associations, or citizen associations, these offices sometimes seek to influence the policy process or to monitor legislative developments. However, offices can also undertake other tasks which are different from policy or legislative activities. These are related to funding, liaising, or networking. Such activities may be complementary to policy and legislative activities, but they may also be quite distinct in terms of the purpose they serve and the objectives they seek to achieve.

I here show that regional offices in Brussels tend to prioritise two types of activities: seeking to influence policy and seeking to uncover funding opportunities. Moreover, policy influence and legislative monitoring tend to go hand-in-hand, to the exclusion of other types of activities. Hence, policy and legislative activism has a polarising effect: offices either pursue these activities or not. Other activities such as funds-chasing, liaising, or networking appear less polarising.

I also show that both contextual and office-level characteristics seem to matter. But I additionally find that, when it comes to prioritising certain activities over others, office-level characteristics seem to matter more. Indeed, higher 
levels of domestic self-government within the national context tend to push influence and legislative activities to the top of offices' agendas, to the detriment of liaison activities. However, an office's length of experience in the Brussels polity affects a wider range of activities. Long-established, experienced offices seem to have the greater know-how and Brussels-based social capital necessary to engage in more complex and cost-intensive activities such as influencing the EU's decision-making process or gaining early legislative information relevant for their home region. This means that these more seasoned offices put a lower emphasis on funds-chasing and networking.

This study represents an encouragement to interest representation scholars to consider two issues which are sometimes neglected. First, it is useful to remember that not all instances of supranational mobilisation by domestic interest groups are aimed at policy influence or legislative activities. There are numerous other benefits related to mobilisation in Brussels. These range from gaining funding - and indeed many private companies benefit from public funding programmes such as Horizon 2020 - to networking with other actors so as to develop cooperation, joint projects, or more simply exchange best practice in the running or implementation of various programmes. Second, it may well be fruitful to focus on non-material resources in addition to material ones. Very often they co-vary. However, there are different types of non-material resources, such as perceived legitimacy, entrepreneurship, technical expertise, or experience of a certain milieu. These types of resources may well provide insights into interest group behaviour beyond those provided by material resources, or the institutional and partisan context. Future research will need to establish whether the patterns observed regarding regional authorities also extend to the wider population of Brussels stakeholders.

\section{Notes}

1. This is the official view of the EU itself. See the description of the Lisbon Treaty on its EUR-Lex services: http://eur-lex.europa.eu/legal-content/EN/ TXT/?uri=uriserv\%3Aai0033 (accessed 18 April 2016).

2. The full list of activities is presented in the online supplemental material.

3. An analysis of the four remaining activities is available in the online supplemental material.

4. For more details on the measure please refer to the online supplemental material.

5. This is also the case for other activities such as responding to information requests. Self-rule decreases the odds of prioritising this activity whilst domestic EU leverage actually increases them (see supplemental material, Table S3). The concomitant use of the self-rule and domestic EU leverage variables does not pose any multicollinearity problems (average model variance inflation factor $=1.91$; highest individual measure is for the number of employees [3.14], followed by domestic EU leverage [3.10], and self-rule [2.74]).

6. Introducing a 'new member state' dummy triggers multicollinearity issues within the models. This is because such a dummy correlates highly with the 
measure of GDP per capita $(\mathrm{r}=-0.82, p<0.0001)$, hence generating variance inflation factor values of 6.98 (new member state) and 5.41 (GDP per capita). When replacing the GDP per capita variable with the new member state dummy, the latter is always insignificant (except for Model 4) and does not affect the reported results apart from the de minimis exception of Model 5, where the office opening date variable becomes insignificant. This is the only model where that is the case. It suggests that networking is less affected by the age of the Brussels office if one no longer controls for GDP per capita but instead includes a new member state dummy. One should note, however, that the effect of office opening date is robust to the simultaneous inclusion of GDP per capita and the region's accession date to the EU (see note 7).

7. I have re-run all models adding the date at which the region joined the EU. The effect of the age of the office across models is unaffected $(+7 \% *$ for influence, $+10 \%^{* *}$ for legislative information, $-10 \%^{* *}$ for funding, $-8 \%^{\star}$ for networking). Indeed, the date of membership of the region correlates only at medium levels with the length of presence in Brussels $(r=0.32, p \leq 0.001)$. This is because half to a third of current EU regions do not have an office (Donas and Beyers 2013; Tatham and Thau 2014), whilst some regions open an office prior to accession (Cekik 2017; Moore 2008a), and others still have offices despite their country having low or non-existent prospects of joining the EU, such as Canada, Norway, Switzerland, Turkey, or the United States (Greenwood 2011). The supplemental material provides a more in-depth discussion of the correlates of the length of presence in Brussels for the offices here surveyed (see section 6 and Table S4). A reverse causation argument could also be made about the relationship between policy influence/legislative monitoring on the one hand and survival in Brussels on the other. The argument would be that a greater emphasis on policy influence/legislation would in turn affect an office's allocation of resources and hence its survival chances. This argument is only partially convincing. While there are inevitable feedback effects, the same survival logic could also be applied to funds-hunting. An office focusing on funding opportunities (i.e. a financially rewarding activity for the region) could also thereby increase its chances of survival. The data do not support this 'success breeds capacity building and hence survival' explanation and rather suggest that older offices simply prioritise different sets of activities than others, irrespective of (i.e. controlling for) their material resources, such as staffing levels or levels of economic development back home.

\section{Acknowledgements}

Special thanks go to Rainer Eising, Patrycja Rozbicka, Daniel Rasch, Aneta Cekik, Anne Rasmussen, Arndt Wonka, Beate Kohler, Yvette Peters, and the anonymous reviewers. Usual disclaimers apply.

\section{Disclosure statement}

No potential conflict of interest was reported by the author. 


\section{References}

Bernhagen, Patrick, and Neil J. Mitchell (2009). 'The Determinants of Direct Corporate Lobbying in the European Union', European Union Politics, 10:2, 155-176.

Beyers, Jan (2004). 'Voice and Access: Political Practices of European Interest Associations', European Union Politics, 5:2, 211-240.

Beyers, Jan, and Tom Donas (2014). 'Inter-Regional Networks in Brussels: Analyzing the Information Exchanges among Regional Offices', European Union Politics, 15:4, 547-571.

Beyers, Jan, Rainer Eising, and William Maloney (2008). 'Researching Interest Group Politics in Europe and Elsewhere: Much We Study, Little We Know?', West European Politics, 31:6, 1103-1128.

Binderkrantz, Anne Skorkjær, and Anne Rasmussen (2015). 'Comparing the Domestic and the EU Lobbying Context: Perceived Agenda-Setting Influence in the Multi-Level System of the European Union', Journal of European Public Policy, 22:4, 552-569.

Blatter, Joachim, Matthias Kreutzer, Michaela Rentl, and Jan Thiele (2009). 'Preconditions for Foreign Activities of European Regions: Tracing Causal Configurations of Economic, Cultural and Political Strategies', Publius: The Journal of Federalism, 40:1, 171-199.

Bomberg, Elizabeth, and John Peterson (1998). 'European Union Decision Making: The Role of Sub-National Authorities', Political Studies, 40:2, 219-235.

Brigevich, Anna (2012). 'Pairing up or Pairing down? Exploring Regional Identity Combinations in the EU', Paper presented at the Council for European Studies Conference, Boston.

Callanan, Mark, and Michaël Tatham (2014). 'Territorial Interest Representation in the European Union: Actors, Objectives and Strategies', Journal of European Public Policy, 21:2, 188-210.

Cekik, Aneta (2017). 'Adapting to Europe? Business Interests and Civil Society Groups in Accession Countries', West European Politics, doi: 10.1080/01402382.2017. 1308696.

Donas, Tom, and Jan Beyers (2013). 'How Regions Assemble in Brussels: The Organizational Form of Territorial Representation in the European Union', Publius: The Journal of Federalism, 43:4, 527-550.

Dür, Andreas, and Gemma Mateo (2012). 'Who Lobbies the European Union? National Interest Groups in a Multilevel Polity', Journal of European Public Policy, 19:7, 969-987. 
Dür, Andreas, and Gemma Mateo (2013). 'Gaining Access or Going Public? Interest Group Strategies in Five European Countries', European Journal of Political Research, $52: 5,660-686$.

Eising, Rainer (2007). 'Institutional Context, Organizational Resources and Strategic Choice. Explaining Interest Group Access in the European Union', European Union Politics, 8:3, 329-362.

Eising, Rainer (2017). 'Imperfect Public Goods and the Logic of Selective Exit in EU Interest Organizations', West European Politics, doi: 10.1080/01402382.2017. 1320173.

Eising, Rainer, Daniel Rasch, Patrycja Rozbicka, Danica Fink-Hafner, Mitja Hafner-Fink and Meta Novak (2017). 'Who Says What to Whom? Alignments and Arguments in EU Policy Making', West European Politics, doi: 10.1080/01402382.2017.1320175.

Greenwood, Justin (2003). Interest Representation in the European Union. Basingstoke: Palgrave Macmillan.

Greenwood, Justin (2011). Interest Representation in the European Union, 3rd ed. Basingstoke: Palgrave Macmillan.

Hooghe, Liesbet, Gary Marks, Arjan H. Schakel, Sandi Chapman, Sari Niedzwiecki, and Sarah Shair-Rosenfield (2016). Measuring Regional Authority. A Postfunctionalist Theory of Governance, Volume I. Oxford: Oxford University Press.

Jeffery, Charlie (2000). 'Sub-National Mobilization and European Integration: Does It Make Any Difference?', Journal of Common Market Studies, 38:1, 1-23.

Klüver, Heike (2012). 'Informational Lobbying in the European Union: The Effect of Organizational Characteristics', West European Politics, 35:3, 491-510.

Kriesi, Hanspeter, Anke Tresch, and Margit Jochum (2007). 'Going Public in the European Union. Action Repertoires of Western European Collective Political Actors', Comparative Political Studies, 40:1, 48-73.

Marks, Gary (1996). 'Exploring and Explaining Variation in EU Cohesion Policy', in Liesbet Hooghe (ed.), Cohesion Policy and European Integration: Building Multi-Level Governance. Oxford: Oxford University Press, 388-422.

Marks, Gary, François Nielsen, Leonard Ray, and Jane Salk (1996). 'Competencies, Cracks, and Conflicts: Regional Mobilization in the European Union', Comparative Political Studies, 29:2, 164-192.

Marks, Gary, Richard Haesly, and Heather Mbaye (2002). 'What Do Subnational Offices Think They Are Doing in Brussels?', Regional and Federal Studies, 12:3, 1-23.

Mbaye, Heather (2009). 'So What's New? Mapping a Longitudinal Regional Office Footprint in Brussels', Paper presented at the European Union Studies Association, Marina del Rey, CA.

Moore, Carolyn (2008a). 'Beyond Conditionality? Regions from the New EU Member States and Their Activities in Brussels', Comparative European Politics, 6:2, 212-234.

Moore, Carolyn (2008b). 'A Europe of the Regions vs. the Regions in Europe: Reflections on Regional Engagement in Brussels', Regional \& Federal Studies, 18:5, 517-535.

Nielsen, François, and Jane Salk (1998). 'Ecology of Collective Action and Regional Representation in the European Union', European Sociological Review, 14:3, 231-254.

Rasmussen, Anne (2012). 'Interest Group-Party Interaction in EU Politics', Party Politics, 18:1, 81-98.

Rasmussen, Anne, and Gert-Jan Lindeboom (2013). 'Interest Group-Party Linkage in the Twenty-First Century: Evidence from Denmark, the Netherlands and the United Kingdom', European Journal of Political Research, 52:2, 264-289.

Tatham, Michaël (2008). 'Going Solo: Direct Regional Representation in the European Union', Regional and Federal Studies, 18:5, 493-515. 
Tatham, Michaël (2011). 'Devolution and EU Policy-Shaping: Bridging the Gap between Multi-Level Governance and Liberal Intergovernmentalism', European Political Science Review, 3:1, 53-81.

Tatham, Michaël (2016). With, Without, or Against the State? How European Regions Play the Brussels Game. Oxford: Oxford University Press.

Tatham, Michaël, and Mads Thau (2014). 'The More the Merrier: Accounting for SubState Paradiplomats in Brussels', European Union Politics, 15:2, 255-276.

Wonka, Arndt (2017). 'German MPs and Interest Groups in EU Multilevel Policy Making: The Politics of Information Exchange', West European Politics, doi: 10.1080/ 01402382.2017.1303247. 


\title{
Is the EU different? Comparing the diversity of national and EU-level systems of interest organisations
}

\author{
Joost Berkhout, Marcel Hanegraaff and Caelesta Braun
}

\begin{abstract}
The European Union interest group population is often characterised as being biased towards business and detached from its constituency base. Many scholars attribute this to institutional factors unique to the EU. Yet, assessing whether or not the EU is indeed unique in this regard requires a comparative research design. We compare the EU interest group population with those in four member states: France, Great Britain, Germany and the Netherlands. We differentiate system, policy domain and organisational factors and examine their effects on interest group diversity. Our results show that the EU interest system is not more biased towards the representation of business interests than the other systems. Moreover, EU interest organisations are not more detached from their constituents than those in the studied countries. Everywhere, business interest associations seem to be better capable of representing their members' interests than civil society groups. These findings suggest that the EU is less of a suigeneris system than commonly assumed and imply the need for more fine-grained analyses of interest group diversity.
\end{abstract}

Is the European Union interest group population different from other interest group populations? According to most experts the answer is yes, especially on two dimensions. On the one end, there is widespread concern that the EU is biased towards business interest organisations because their proportion is larger in the EU than in domestic interest group populations, leading observers to conclude that the EU system is more receptive to business interests (e.g. Berkhout et al., forthcoming).

This is an Open Access article distributed under the terms of the Creative Commons Attribution-NonCommercialNoDerivatives License (http://creativecommons.org/licenses/by-nc-nd/4.0/), which permits non-commercial re-use, distribution, and reproduction in any medium, provided the original work is properly cited, and is not altered, transformed, or built upon in any way. 
On the other end, interest groups in Europe are also thought to be more detached from constituents than equivalent groups in most domestic systems (Kohler-Koch 2013: 16). This relates to the organisational tension identified by Schmitter and Streeck (1999:21) between the logic of membership and the logic of influence which means that interest associations continually have to manage demands from both members and policy-makers. In particular regarding the $\mathrm{EU}$, the concern is that interest groups are more focused towards policy-makers at the expense of membership demands. This is problematic from a democratic perspective as interest groups might be more willing to listen to the arguments of policy-makers than represent the interests of their members.

To date, however, we do not know whether these concerns are valid as there have been no direct comparisons of the interest group population in the EU with other political systems (but see Mahoney 2008). To put it differently, while we know that there are more business groups active in Europe than other types of interest organisations, we do not know whether this relates to the openness of the EU system, reflects an indication of bias, or simply is because economic issues are more discussed at this level. Likewise, while we know that groups at the European level are rather detached from their membership base, we do not know whether this is substantially different from membership involvement in domestic political systems. At this point we cannot meaningfully assess such questions because comparable data of interest group populations across political systems are lacking. To overcome this problem, we aim to provide a first comparison of different interest group populations in a single research design. We collected interest group population data in four countries (France, Great Britain, Germany and the Netherlands) and in the EU based on similar sampling strategies and coding schemes. This design provides us with the best opportunity to analyse the uniqueness of the EU compared to domestic interest group populations across several dimensions.

In our analysis we focus on two dimensions of diversity in interest group populations. First, we analyse whether there is a business bias in the EU interest group population. Several studies have suggested the existence of an increasing mobilisation bias toward business groups at supranational governance levels compared to national levels (Baumgartner et al. 2009; Beyers and Kerremans 2007; Hanegraaff 2015). A particular, sui generis EU version of this argument can be found in earlier studies on European integration (Eising 2004). To examine a potential EU business bias, we compare the proportion of business groups at the EU system level with those in the four countries included in this study. More importantly, we also assess differences in business mobilisation at the level of policy domains. This is important because normative concerns about business bias are related to business influence on (specific) public policies. To do this in a meaningful manner, we compare the share of business groups active in similar domains such as in agricultural, environmental, or energy policy. If we observe a higher proportion of business interest groups within these domains 
at the EU level compared to the domestic level, this is indeed an indication that the institutional characteristics of the EU produce a more severe bias. Yet if there is no significant difference between the EU and the four countries this suggests that characteristics of the policy domains attract business interests rather than the specific EU institutional environment.

Second, we study variation in the representational capacity of groups active across different interest group populations. Representational capacity refers to the ability of interest groups to operate as mediating organisations by aggregating societal interests and translating these interests to policy-makers. In other words, we examine how interest groups in the EU and in the four countries balance policy interests with membership involvement and hence are capable of operating as transmission belts. This issue has attracted much attention as it taps directly into the debate on whether or not the EU interest groups increasingly become part of the so-called 'Brussels bubble', thereby potentially ignoring the transmission belt function interest groups should play in democratic systems (e.g. Kohler-Koch 2013; Streeck and Schmitter 1991). While most current studies emphasise that EU groups are substantially detached from their constituency (Kohler-Koch 2013: 16; Schmitter and Streeck 1999: 21, 54), some argue otherwise. The fact that European associations 'outsource' membership-oriented activities to national associations or affiliates means that these organisations have developed relatively advanced internal structures for membership engagement (De Bruycker et al. 2016). As a result, the representative capacity, or the ability to translate membership preferences to policy-makers, could in fact be more advanced at the EU level. Such strengths can, on the one end, reduce the bias of the interest group system by empowering non-business groups, but, on the other end, it can also enhance a business bias in case business interest associations appear more qualified to 'transmit' the concerns of members to policy-makers. We therefore also examine whether the representational capacity of different types of interest groups varies across the $\mathrm{EU}$ and at the domestic level.

In the following, we set out our theoretical framework. We discuss our two analytical concepts of diversity - business bias and bias in representational capacity - and how we expect them to vary across the EU and national governance levels. We subsequently present our research design, after which we test our hypotheses. We end with some concluding remarks and an avenue for future research.

\section{Organisational diversity across interest group systems}

The diversity of interest group systems has been a traditional concern in the interest group literature (Baumgartner and Leech 1998; Beyers et al. 2008). A biased pattern of interest representation is potentially problematic as it may imply that some interests have a magnitude of influence that is disproportional to their interests in society (Lowery and Gray 2004; Lowery et al. 2015). This is a valid concern, and especially for the EU interest group population, as empirical 
studies repeatedly show a substantial skewness in the pattern of interest representation, such as a dominance of business interests in supranational systems such as the EU (Rasmussen and Carroll 2013; Schlozman et al. 2015).

The question, however, is whether the observed skewness is indeed an indication that the EU interest population is biased. To answer this question, we take up three challenges: first, we follow Lowery and Gray's (2004: 21) advice that the assessment of diversity or bias 'should entail comparisons across time, jurisdictions or venues.' While 'bias' may be impossible to identify in absence of a proper benchmark of 'unbiasedness' (Lowery et al. 2015), comparisons allow us to identify relative bias. Second, there is a theoretically unresolved puzzle regarding the relationship between the level of government and the likely bias of the group system. That is, the collective action problems of diffuse interests seem to be more easily resolved at lower levels through the provision of expressive and solidary selective benefits (Wilson 1974: 30-55). This should make it easier for social movements and civil society groups to maintain themselves locally rather than regionally, nationally, or internationally. At the same time, the expansion of the scope of conflict from the lower to higher level potentially favours exactly those groups that are typically excluded from narrowly defined local conflicts, and in that way increase diversity (Schattschneider 1960), a phenomenon or mechanism similar to what Keck and Sikkink (1998) label the 'boomerang pattern'. This theoretical conundrum is only infrequently studied empirically: an important omission in the population literature is a lack of studies that pay attention to multi-level dynamics in interest group populations by comparing geographical levels within communities (but note such attention in the United States case, e.g. Baumgartner et al. 2009). Third, there is an EU-specific discussion related to theories of European integration about the relative tendency of several types of interests to mobilise at the European level. These theoretical debates, in broad strokes, relate to incentives on the part of European institutions to seek the backing of especially major business interests (Beyers and Kerremans 2007; Eising 2007).

As said, however, suspicions of bias in the EU interest group population remain mostly tentative. We lack comparative studies to empirically assess whether the EU interest group population is indeed different from those in other political systems. To overcome these problems we rely on a comparative design to analyse two dimensions of interest group diversity: business bias and representational capacity. Both have important normative consequences for how we view the EU as a democratic and responsive political system.

\section{Business bias}

Contemporary research on EU interest representation commonly differentiates between citizen groups and business interest representation (Dür et al. 2015; Eising 2004, 2007; Klüver 2013; Rasmussen and Carroll 2013). Building on this research, we compare the presence of business and other interests in the 
EU and the national interest group populations. As indicated, several scholars suggest that the interest group system in the EU is more biased towards business interests than national political systems.

First, the EU's geographical scale exacerbates collective action problems that typically affect non-business interests in a more severe way. To start with, groups vary in the extent to which they have a 'local' membership base. Groups that rely on national resources to maintain themselves, such as national government subsidies or the 'local' constituencies of certain unions, are less likely to mobilise at the EU level (Beyers and Kerremans 2007). In addition, the so-called 'public sphere' deficit (e.g. Schlesinger 1999) at the EU level, i.e. the absence of a common EU media environment hinders mobilisation of non-business groups that typically rely on national media sources to arouse salience of the issues they stand for and mobilise their constituency. This makes it more challenging for them to mobilise EU-wide through professional marketing, direct contacts with journalists, and joint activities nurturing solidary or purposive benefits for their constituencies. As a result, the EU interest system is seen by many as being biased towards business interests.

We contend, however, that assessing bias at the system level does not take into consideration that bias is structured at the level of policy domains. For instance, it is expected that we would see more citizen group activity on cultural or social issues, while the political goals of business groups lead them to be more active on economic issues. In other words, it could very well be that the overall bias we observe in the $\mathrm{EU}$ is not caused by the particular institutional EU context but is a function of the type of issues on the agenda of the EU institutions, given its explicit mandate to regulate economic, rather than social or cultural policies (Majone 1998). Despite these trepidations, most scholars still argue that the EU favours the input of business groups, regardless of the issue on the table (e.g. Bouwen 2004; Coen and Katsaitis 2013), spurred by the demand of EU policy-makers. Coen and Katsaitis (2013), for instance, note that the regulatory nature of most EU policies and the small number of the Commission's staff, produces 'demand' on the part of policy-makers for technical information. Scholars also point out that different EU institutions, most notably the European Parliament and the European Commission, attract different types of lobbyists (Bouwen 2004). Combined, the literature would predict that the EU-level interest group population is more biased than the national-level interest group populations towards the mobilisation of business groups over other types of organisations. We therefore hypothesise that the EU is more biased towards business groups both at the system level and at the level of policy domains. Regarding the latter hypothesis, we take into consideration that it has not yet been tested directly but is based on aggregate assessments of bias in the EU. It could be that at the level of policy domains business bias is absent.

Hypothesis 1: The EU interest group population as a whole and per domain is more biased towards business than national interest group populations. 


\section{Representational capacity}

Our second conceptualisation of diversity takes into account how interest groups balance their political orientation with their membership orientation. We refer to the combination of interest aggregation and interest articulation as representational capacity. We define representational capacity as the capability of groups to manage the membership involvement with the exercise of political influence. This directly builds upon the organisational tension identified by Schmitter and Streeck (1999: 21-54) between the logic of membership and the logic of influence: interest associations continually have to manage demands from both members and policy-makers. This is not an easy task. Members put other demands on interest organisations than policy-makers. Members prefer organisations with a clearly demarcated identity so that their interests align with those of other members and are distinct from other organisations. To ensure their support in the form of dues, participation in (voluntary) activities, and information on what members prefer, organisations have to provide selective benefits, such as services or collective insurances to their membership. Ensuring membership engagement with the organisation thus calls for relatively specialised organisations so that members perceive their interests to be properly represented. Policy-makers, on the other hand, require a distinct set of policy-relevant information, including constituency information, technical expertise, but also information about broad societal support. In other words, they prefer generalist organisations to have a guarantee on the legitimate nature of the policy input (see also Kohler et al. 2017). This tension can lead organisations to specialise in the provision of policy input (similar to think tanks) or the involvement of members (similar to social clubs).

Assuming some level of organisational specialisation, conceptualising diversity in terms of representational capacity is relevant in at least two important ways. First, it points our attention to the kind of policy information we can expect groups to offer to policy-makers. In broad terms, this may be information on the interest or preference of the members of the organisation or it may be information on the technical quality of certain proposals (Bouwen 2004; Braun 2012). Organisations with a strong focus on membership involvement are more likely to provide a different type of policy information compared to organisations with a well-developed policy orientation (Daugbjerg et al., 2017). Hence, organisational specialisation results in different kinds of interest groups capable of offering distinct types of policy information (Minkoff et al. 2008).

Second, the way in which interest groups strike a balance between policy influence and membership involvement determines the extent to which they are capable of performing a 'transmission belt' function. After all, attributing a transmission belt function assumes that interest groups simultaneously transmit societal interests to policy-makers and convey policy compromises 
to their membership (Braun 2015; Halpin and Fraussen 2017). This notion is especially relevant in neo-corporatist approaches to interest representation (Schmitter and Streeck 1999) and particularly applicable to the EU context as the European Commission explicitly requires such an intermediary function of the groups it reaches out to (European Commission 2001; Kohler-Koch and Finke 2007).

The representational capacity of interest groups and the different dimensions groups tend to prioritise are likely to vary across national- and EU-level interest group populations. First, the relative 'weakness' of EU-level policy-makers allows interest groups, even when relatively non-cohesive or specialist, to be involved in the political process. This should produce a relatively strong focus on interest articulation at the EU level compared to the national level. Second, as regards the membership environment of European umbrella groups, we expect multi-layered European federations to 'outsource' their membership-oriented activities to national associations or affiliates. We expect that these organisations have advanced internal structures for membership engagement, offering multiple types of membership and well-developed channels for engagement in EU public policy-making. By comparison, at the national level, such a specialised type of organisation would not exist and similar types of task division are also unlikely. As a result, we hypothesise:

Hypothesis 2: EU-level interest groups have stronger representational capacity than interest groups active at the national level.

\section{Design}

To test our hypotheses, we compare the composition of national-level and EU-level populations of politically interested membership organisations. This data collection strategy is in line with recent mapping studies of interest group populations (Berkhout et al., forthcoming; Halpin and Jordan 2011). Next to the EU level, we select four member states: France, United Kingdom, Germany and the Netherlands. As our expectations relate to differences between the EU and national-level political systems, we do not focus on systemic factors explaining variation across national-level interest group populations. At the same time, by selecting four countries considered to belong to different interest representation regime types (e.g. Balme and Chabanet 2008: 28) - the UK as a pluralist system, the Netherlands and Germany as corporatist systems, and France as statist system - we enhance the external validity of the observed differences between the EU and these different types of member states. We combine top-down (policy-oriented) and bottom-up (mobilisation-oriented) mapping strategies to construct representative samples of the organisational populations. The use of different types of sources reduces potential sampling bias (cf. Berkhout and Lowery 2008). These sources include, first, directories 
of associations, most notably the European directory of Public Affairs (2014), OECKL Deutschland (2011), ${ }^{1}$ the Pyttersen Almanak (2014), ${ }^{2}$ the Directory of British Associations (2012), ${ }^{3}$ and a combination of French lists of associations. ${ }^{4}$ The sections listing business, professional and trade associations, and the section on NGOs of the European Public Affairs Directory are comparable to the relevant sections of the national directories of associations. Secondly, from the 'top down', we include membership organisations active in the parliaments and sample these from: the Lobby register of the Bundestag (2014), the register of accredited lobbyists to the European Parliament as can be found in the EU Transparency Register (2014), and from the participants in hearings and roundtables in the French (2011-2014), Dutch (2011) and British (2011) parliaments. The Dutch and British parliamentary lists have been shared by researchers in the Interarena project (see Helboe Pedersen et al. 2015). The sample sizes vary between 309 interest associations in the Netherlands and 448 interest associations in the United Kingdom amounting to a total of 1785 interest associations.

These sampling procedures do not produce perfectly comparable samples of interest groups. First, as regards the directories, for the French case we could not rely on a general inclusive directory and used alternative lists instead. This makes the inclusion of established, professionalised associations in the French case more likely than in the other cases. The figures presenting data on membership involvement in the French case (Figure 3) should be read with this in mind. Second, as regards the parliamentary data, the Bundestag and European Parliament registers do not require 'invitation' on the part of members of the parliament whereas presence in the parliamentary hearings in the UK, France and the Netherlands does. We do not aspire to compare the individual member states with each other and these differences largely average out in the comparison with the EU.

\section{Data collection}

To examine our two concepts of diversity (group type and representational capacity), we rely on information provided on the websites of the interest groups. This information has been coded by six extensively trained master's students. The coders are fluent in at least two languages and were assigned records from multiple countries and sources. The data sources were sampled randomly and the sample presented below includes a sufficient number of organisations for the aggregate-level analysis undertaken. The intercoder-reliability test shows that coders reached higher agreement on the policy interest scale (Krippendorff Alpha 0.61) than on the members-service scale (Krippendorff Alpha 0.38). Note that when accounting for co-variation, these scores need not be interpreted conservatively (Neuendorf 2002: 152). Records coded in the first months of the data collection were coded by two coders (25\%) and only included when the 
coders agreed on the selection of the organisation and its types of members. This implies that for the data we use in this paper the intercoder-reliability scores are higher than for the test records. The operationalisation of the (in) dependent variables is summarised in Table 1.

We have two dependent variables. The first dependent variable, business bias, is the proportion of business interest associations per policy domain. We distinguish between business associations and other interests based on their types of members. Associations with commercial firms as members are business interest associations. As said, we focus on bias in policy domains because normative concerns about the 'overrepresentation' of business interests are mainly related to the presumably business-friendly implications for policy-making. To see whether or not policy-makers in the EU are more receptive to business groups than those at the national level, we need to compare bias at the level of policy-makers which are structured along policy domains (Pappi and Henning 1998: 554-6). We use the UN Classification of the Functions of Government (COFOG) to measure policy domains. Each organisation is coded in the most specific category applicable. We then aggregate these categories into 18 policy domains. Organisations may be active in multiple policy fields, but we rely only on the area which coders judged to be the most important. Overall, this provides us with the proportion of business groups per policy domain across the four countries and the EU.

We disaggregate our second dependent variable, representational capacity, into three distinct components. First, the variation in policy interest is the extent to which organisations provide policy input and position themselves in relation to specific public policy programmes. This is indicated in press or policy statements published on the website. Second, student coders classify the extent to which the organisation involves members in organisational decision-making and activities. This includes participatory structures such as committees, membership meetings and internal elections aimed at aggregating and representing the preferences of members. Third, we combine these measures into a single indicator of the organisations' capability to represent interests. More specifically, we construct a dummy variable that identifies organisations with high levels of policy involvement and membership involvement (scores of 4 or higher). It follows that these interest groups have high representational capacities and are capable to perform the transmission belt function (see Appendix for full coding instructions).

The independent variable in both analyses is the variation across the five political systems (the EU and the four countries). We thereby aim at isolating the institutional effect that causes the variation in interest group diversity, in particular the distinction between EU and national-level political systems. We include country dummy variables in the analyses to see whether the countries and the EU differ regarding the proportion of business groups active and the representational capacity of individual organisations. 
Table 1. Variables, operationalisation and measurement.

\begin{tabular}{lc}
\hline Variable & \multicolumn{1}{c}{ Variable description } \\
\hline $\begin{array}{l}\text { Dependent variables } \\
\text { Business bias }\end{array}$ & $\begin{array}{c}\text { Proportion of business interests } \\
\text { in policy domain } \\
\text { Representational capacity 1 - } \\
\text { policy interest dimension } \\
\text { which an organisation is } \\
\text { involved in policy-making }\end{array}$ \\
$\begin{array}{l}\text { Representational capacity 2 } \\
\text { membership dimension }\end{array}$ & $\begin{array}{c}\text { Membership involvement: the } \\
\text { extent to which an organisa- } \\
\text { tion involves its membership }\end{array}$ \\
$\begin{array}{c}\text { Representational capacity 3 }- \\
\text { ideal type transmission belt' }\end{array}$ & $\begin{array}{c}\text { Combination of policy interest } \\
\text { and membership dimension }\end{array}$
\end{tabular}

Independent variable

Institutional effect ( $\mathrm{H} 1$ and $\mathrm{H} 2)$

\section{Control variables \\ Density}

Policy competence

Group type

Membership structure

Social/leisure focus
Effect of different governance levels

Number of interest groups per policy domain in member state/EU level

Extent to which a policy domain is an EU competency; conversion table of COFOG coding into EU or national competencies

Business vs other groups; based on type of members

Presence of decentralised organisational units, such as geographical or functional chapters, or sub-associations

Organisations that are predominantly focused on social or leisure goals
Details

Based on membership variable (see below)

1 to 6 scale that indicates no policy interest at all (1) and full policy interest (6). (see Appendix for full coding-scheme)

1 to 6 scale that indicates membership involvement ranging from: involvement at all (1) to fully run by members (6) (see Appendix)

Variable based on policy interest and membership involvement scales.

Dummy variable: 1 = organisations with a score higher than 4 on both scales; 0 = organisations with lower scores on both scales

Dummy variables that represent variation between: the Netherlands, the UK, France, Germany and the EU level

Proportions per policy domain based on the COFOG classification (see http://unstats.un.org/unsd/cr/registry/regcst.asp? $\mathrm{Cl}=4$; and below)

EU competency: 05: Environmental protection; 0.42: Agriculture

Shared competency: 01: General public services; 02: Defence; 04: Economic affairs; 0.43 : Energy; 0.44: Manufacturing and construction; 0.54: Landscape protection; 0.45 : Transport

National competency: 03: Public order and safety; 06: Housing and community amenities; 07: Health; 08: Recreation, culture and religion; 09: Education; 10: Social protection; 0.73: Hospital services; 0.82: Culture; 10.4: Family; 10.7: Social exclusion

Dummy variable: $1=$ Members are commercial firms, $0=$ Members are not firms. In Table 3: additional category used: members are individuals as professional

Does the organisation have an 'indirect' membership structure?

$1=$ Yes, $0=$ No

Domain of membership according to the International Classification of Non-Profit Organizations is:

1) Group 1 'Culture and recreation' or Group 10'Religion'

2) Not in any of these 
We also control for several factors. For our first analysis, on business bias, a first crucial control variable is the competency-level of policy domains. The main reason for doing so is the strong regulatory nature of the EU system, implying a large amount of economic competences. This means that any skewness towards business groups might be a result of the type of issues that are dealt with rather than a function of system-level institutional prioritisation of business interests. We use a conversion table (see Table 1) based on our own assessment of policy competence of policy domains and distinguish among domains of EU competence, shared and national competences. Secondly, we control for the density of the policy domain, as business bias could be a result of the crowdedness of policy domains, although previous findings are inconclusive in this regard. That is, at the level of issues, Baumgartner and Leech (2001) suggest that business interest organisations are more likely than others to maintain presence on issues with a low density, whereas Berkhout et al. (2016) found a higher relative presence of business interests on 'crowded' issues. To measure the relative density, we use the proportions of actor types per policy domain in each system.

We add three controls to the analyses on representational capacity. First, we control for group type (business or professional group). Firms, as members of associations, are already 'organised' and their participation is likely to be of a different kind than that of individual citizens (e.g. Offe and Wiesenthal 1980). Second, we control for the nature of the membership structure (presence of geographical or functional chapters or sub-associations). Such subsections are tools used to manage organisational consensus formation and should therefore be positively related to membership involvement. Finally, we also control for predominant social or leisure goals of organisations. Such goals are likely to reduce the policy orientation of groups and affect the nature of the membership involvement. They are likely to lower the representative capacity of groups.

\section{Analysis}

Our analysis proceeds in two steps. First we descriptively assess business bias across the different levels of governance. By means of a multivariate OLSregression analysis, we subsequently examine the statistical significance of these differences between the EU and national levels while controlling for several alternative explanations of bias. Second, after describing differences regarding the representative capacity of organisations we follow up with regression analyses to account for the variation between the EU and national levels.

Figure 1 shows the proportion of associations representing firms as members per system. Using this measure, about half of the groups in the EU are business associations. This is consistent with findings in recent studies (see Berkhout et al., forthcoming; Lowery et al. 2015). The share of business interest groups in the EU is similar to that in France and higher than those in the Netherlands 


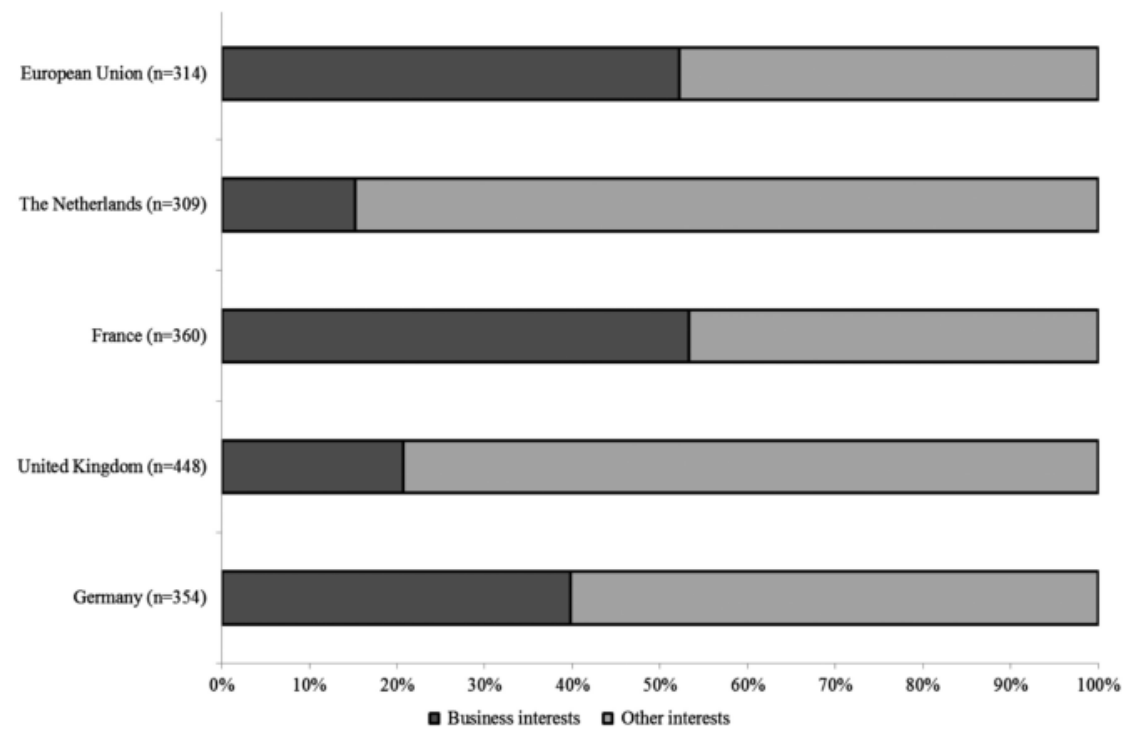

Figure 1. Proportion of business interests per political system.

and the United Kingdom. Please note that we here operationalise bias in the form of proportions of group types per political system rather than per policy domain (as we will do in the regression analysis in Table 2). Moving to the domain level allows us to examine differences in bias across domains. This matters greatly for our understanding of the policy implications of bias because averages per system mask the strong bias that exists in certain policy domains. That is, as a crude indicator, 13 out of 91 policy domains have $100 \%$ business interest representation, whereas in seven of them we note a complete absence of business interests. There must be important sector-level dynamics that explain such variation. We will examine this in the regression models in Table 2.

To test whether business bias can be explained by systemic, institutional effects we ran a multivariate OLS-regression analysis on the proportion of business interests per policy field. The country coefficients restate the minor cross-national differences observed in Figure 1. We control for the organisational density of the policy domain and do not find a significant relationship. This means that business bias is unrelated to the number of organisations active within a given community. This is in contrast to findings at the level of issues (Baumgartner and Leech 2001; Berkhout et al. 2016), where business interest organisations were found to have lower (US), respectively higher (EU), relative presence on 'crowded' issues. The bottom rows of the table indicate that a larger proportion of business interest organisations is active in policy domains in which the EU - rather than the member states - enjoys exclusive competences. Areas of exclusive EU competences, such as trade and market regulation, attract 
Table 2. OLS regression on the proportion of business interest associations per policy domain, $n=90$ policy domains in four countries.

\begin{tabular}{llc}
\hline Country & The Netherlands & -0.15 \\
Reference category: European Union & & $(-1.27)$ \\
& France & 0.18 \\
& & $(1.53)$ \\
& United Kingdom & -0.15 \\
& & $(-1.33)$ \\
& Germany & 0.10 \\
Density & Proportion of organisations in policy field & $(0.88)$ \\
Policy competence & & 0.089 \\
& National competence & $(0.93)$ \\
& & $-0.53^{* * *}$ \\
& Mixed national/EU competence & $(-4.12)$ \\
& & -0.16 \\
& $R^{2}$ & $(-1.24)$ \\
\hline
\end{tabular}

Standardised beta coefficients; $t$ statistics in parentheses; $n=90$.

${ }^{*} p<0.10 ;{ }^{* *} p<0.05 ;{ }^{* * *} p<0.01$.

business interest organisations to a stronger extent than other interest groups, regardless of this being at the EU or national level.

We now turn to the second part of the empirical analysis in which we focus on representational capacity, and for which we individually assess policy interest, membership involvement and subsequently examine the combination of a group's policy interest and membership involvement. High scores on both dimensions indicate a strong representational capacity. We start by presenting the frequency distributions of the policy interest and membership involvement scales in Figures 2 and 3. The national distributions resemble each other. As can be seen in Figure 2, around 20\% of the organisations is fully committed to influencing public policy, and, when adding up the proportions of the top categories on the x-axis (labelled 4, 5 and 6) one finds that around $40 \%$ of the organisations falls into any of these categories (ranging from 33\% in the United Kingdom to $44 \%$ in Germany). The organisations in these national systems also are relatively similar regarding the extent to which they allow members to be involved in the organisation. Around $40 \%$ of the organisations provide substantial opportunities for members to engage within the organisation (Figure 3).

The key difference is between the organisations active in the EU and those active at the national level. EU-level organisations are definitively more policyoriented, with about $50 \%$ aiming to influence policy, and surely less open to involve their members in strategic decision-making. Less than $10 \%$ of them fully embrace membership control over the organisation. Around 30\% (labelled 5) does allow substantial membership input. Consequently, the differences between the EU and the national systems in the sums of the top categories (labelled 4, 5 and 6) are quite substantial (ranging from 58\% in the EU to $83 \%$ in Germany). These differences are in line with our expectations. They indicate that EU-level interest groups tend to be better at engaging with policy-makers rather 


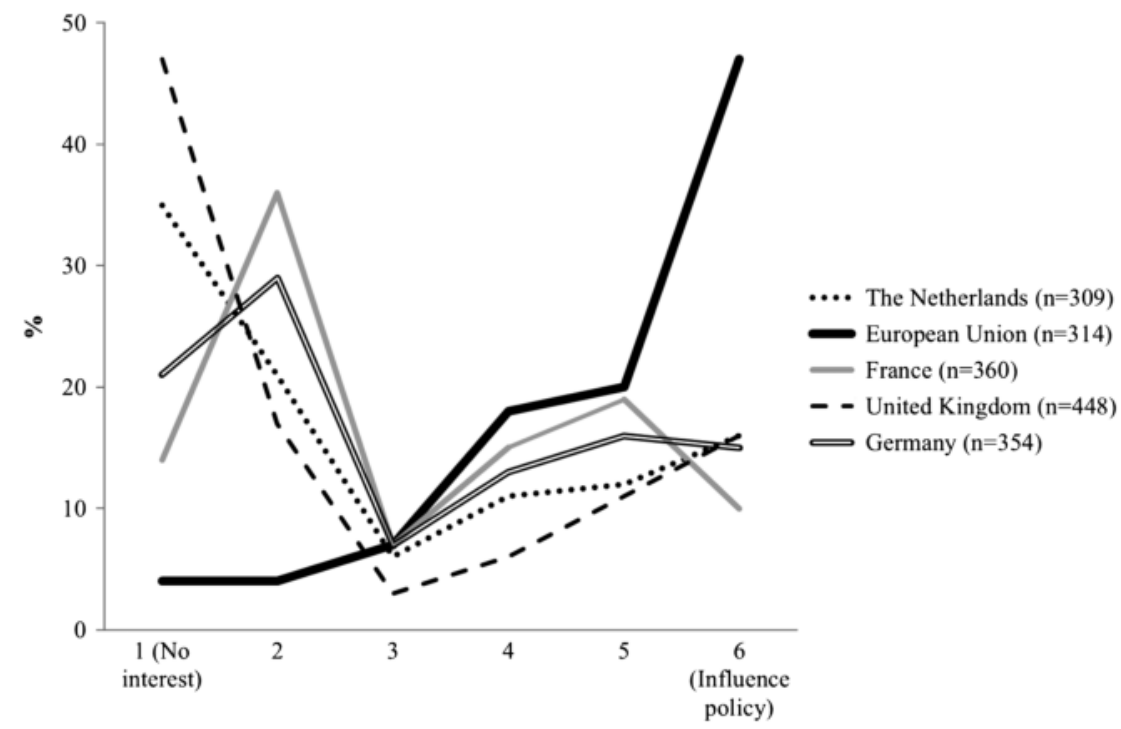

Figure 2. Organisational orientation per political system: frequency distributions of scores on policy interest.



Figure 3. Organisational orientation per political system: frequency distributions of scores on membership involvement.

than with their members when compared to national groups (see also KohlerKoch and Buth 2013). Nonetheless, we note that EU organisations tend to score relatively high on both dimensions. Moreover, these aggregate differences do 
not tell us much about the specialisation of individual organisations and may no longer hold when controlling for organisational factors. We look at this in the discussion of Table 3.

Table 3 presents nine OLS and three logistic regression analyses on the policy involvement and member involvement of the individual interest organisations studied in the EU and the four member states. These are clustered in three models. Model 1 assesses whether EU-level groups have indeed a stronger representative capacity than national-level groups (hypothesis 2). We compare the countries and control for clubs interested in culture and social activities. ${ }^{5}$ These tend to be more numerous at the national level than at the European level. The nature of the participation of members in these organisations is, partially, of a different kind than the decision-making-oriented participation common in other types of organisations included in our study. The coefficients are significant in the expected directions (negative for policy interest, positive for membership involvement, negative for the combined measure). As already observed in Figures 2 and 3, the orientations towards polices and members differ between EU-level groups and national groups. As can be seen from the negative coefficients in Model 1(1), national interest organisations tend to be less policy interested than EU-level organisations. The reverse is the case for membership involvement, Model 1(2). The logistic regressions assess the likelihood that organisations have high scores on both policy interest and membership involvement ( $>4)$. The negative significant coefficients reported in Model 1(3) indicate that EU organisations generally are 'stronger' than their national counterparts. They are more likely to have high scores on both dimensions, and, in that way, should be able to develop stronger representational functions than national organisations.

Model 2 controls for the type and structure of membership. The positive and significant coefficients in all sub-models indicate that business, professional and multi-levelled associations compared to other organisations are more likely to be interested in public policy, engage members and combine these functions. Also note that the addition of these explanatory variables adds only little explanatory power to the models (compare Model 1 and Model 2). This indicates that when it comes to representational capacity, cross-national differences are more important than the differences among the types of interest represented. In Model 3 we include an interaction effect between EU and business interest associations. The coefficient of this variable is positive and significant for Models 3(8) and 3(9) on membership involvement and representative capacity. Business interest associations in the EU, compared to those active at the national level, are more likely to involve members and, as a consequence, more capable in representing interests in the policy process. We visually present the strength of this relationship in Figure 4 where we plot the predicted probabilities of the representative capacity of business interest associations versus other association in the EU and the member states studied. ${ }^{6}$ The figure demonstrates 









Figure 4. Predicted probabilities of the representative capacity of business interest associations versus other associations in the $\mathrm{EU}$ and four member states, adapted version of Model 3(9) from Table 3.

that business interest associations have a stronger representational capacity, in particular those at the EU level.

\section{Conclusion}

This paper is a first attempt to compare interest group populations across governance levels in the EU. More precisely, we compared the business bias and representational capacity of interest groups in the EU with those in France, the UK, the Netherlands and Germany. As regards business bias, we found no substantial differences between the interest group population at the European level and those at the national level. Our analyses suggest that system-level variation is not associated with this variation but that policy competences are and possibly also other policy domain-related factors. This is in line with the finding that interest group mobilisation is largely specific to policy domain or issue (Berkhout et al., forthcoming). Put more concretely, this means that, overall, there might be more business groups active in Europe, but at the level of policy issues, for instance as regards agriculture, the environment or construction policy, the share of business groups in the EU compares to their shares in the four countries. This finding supports the idea that business bias is related to the type of issues on the EU legislative agenda rather than the effect of institutional characteristics.

In terms of representational capacity we find a stronger policy engagement at the EU level as opposed to the national level and a stronger membership orientation at the national level compared to the EU level. Yet, surprisingly, 
our results also suggest that in particular EU-level organisations with either professionals or firms as members and a multi-level membership structure have the strongest representational capacity. So, although in terms of business bias the diversity of the interest group population at EU level does not seem to be as limited as is commonly argued, in terms of our second aspect of diversity, representational capacity, the EU-level system seems more biased to business interests. They seem, across the board, to perform better in terms of representational capacity than other types of interests. The bias towards business in the numbers of organisations active is consequently exacerbated by the organisational capacity of business interest associations to aggregate and articulate interests.

We would like to identify a number of venues for future research. First, business bias is a far more complex phenomenon than commonly understood. That is, business and non-business interests do not randomly distribute over policy domains. And various factors affect this process. Some country-specific institutions may encourage encompassing interest aggregation, certain policy domains may be very open to various groups, and certain interests are just not easy to organise. Second, assuming that we want to study implications for public policy or representation more broadly, business bias must be related to the varying capacities of organisations to exhibit meaningful activities in relation to politics. In other words, this means that the 'transmission belt' function of interest organisations is deeply related to questions about bias. That is, 'transmission' puts substantial organisational demands on groups that only relatively strong groups are willing and able to develop. Our finding that there is a strong correlation between business interests and representational capacity suggests that especially business interests are better transmission belts than others, and that this is particularly the case at the EU level. This is in line with previous research demonstrating that more consultation practices seem to reinforce existing biases (De Bièvre et al. 2015). This is normatively problematic in light of the Commission's deliberate outreach to civil society organisations on precisely the grounds of their representational capacity (Perez-Solorzano Borragan and Smismans 2012). Third, the limited findings on difference between EU and national political systems also nuance arguments about the effect of political institutions for the formation of interest group communities. Institutional factors such as the legal competence of policy-makers matter at the level of policy domains rather than political systems. In addition, supply factors, i.e. the structure of the economy and salience of issues in a given geographical setting as well as the internal structure of interest groups, seem to outweigh attempts by government to structure the composition of interest group communities (Berkhout et al. 2015).

Our study is hopefully a stepping stone towards more comparative studies of interest group populations. Over the last decade students of interest groups have started to map interest group population in many countries. Our study 
shows the potential relevance of comparing the outcomes of these studies. We therefore urge other scholars to engage in comparative studies of interest group density and diversity across different political systems, but even more so across different policy domains within distinct political systems.

\section{Notes}

1. We rely on the selection of 4830 'politically active' associations by Jentges et al. (2012).

2. The Dutch Pyttersen's Almanak (2014), section A, lists 9601 collective action organisations which are (primarily) non-profit and 'of supra-local interest'.

3. The Directory of British Associations reports collective action organisations of 'national' interest.

4. There is no French directory of associations similar to the directories in the other countries. Similar to the EUROLOB II project (Kohler-Koch et al. 2017), we therefore use the members of the two major business interest federations. These are the 220 professional member-federations of the French association for smalland medium-sized companies Confédération Général des Petites et Moyennes Entreprises (CGPME) (see http://www.cgpme.fr/le-reseau/federations) and the 87 member-federations of the major employers' federation Mouvement des Entreprises de France (MEDEF) (see http://www.medef.com/medef-corporate/ le-medef/federations.html). The study also includes the 133 members (Titulaire and Suppleant) of the Le conseil national de la vie associative (2014) in order to guarantee the inclusion of French citizen groups (see http://www.associations. gouv.fr/112-le-conseil-national-de-la-vie.html).

5. Organisations classified under Group 1 and Group 10 of the International Classification of Non-Profit Organisations.

6. We calculated these probabilities on the basis of an adapted version of Model 3(9) from Table 3. We contrasted the EU-level groups to all national groups rather than including each country as a dummy variable.

\section{Disclosure statement}

No potential conflict of interest was reported by the authors.

\section{Funding}

We would like to acknowledge the financial support of the Netherlands Organisation for Scientific Research project [grant number 461-10-519]. 


\section{References}

Balme, Richard, and Didier Chabanet (2008). European Governance and Democracy: Power and Protest in the EU, Governance in Europe. Lanham: Rowman and Littlefield.

Baumgartner, Frank, and Beth Leech (1998). Basic Interests: The Importance of Groups in Politics in Political Scientists. Princeton, NJ: Princeton University Press.

Baumgartner, Frank, and Beth Leech (2001). 'Interest Niches and Policy Bandwagons: Patterns of Interest Group Involvement in National Politics', Journal of Politics, 63:4, 1191-1213.

Baumgartner, Frank, Virginia Gray, and David Lowery (2009). 'Federal Policy Activity and the Mobilization of State Lobbying Organizations', Political Research Quarterly, $62: 3,552-67$.

Berkhout, Joost, et al. (2015). 'Interest Organizations Across Economic Sectors: Explaining Interest Group Density in the European Union', Journal of European Public Policy, 22:4, 462-80.

Berkhout, Joost, and David Lowery (2008). 'Counting Organized Interests in the European Union: A Comparison of Data Sources', Journal of European Public Policy, $15: 4,489-513$.

Berkhout, Joost, Caelesta Braun, and Marcel Hanegraaff (2016). 'The Not So Hollow Core: How Active are Interest Groups in Europe?' Paper prepared for the ECPR General Conference, Prague, 5-8 September.

Berkhout, Joost, Jan Beyers, Caelesta Braun, Marcel Hanegraaff, and David Lowery (Forthcoming). 'Making Inference across Mobilization and Influence Research: Comparing Top-Down and Bottom-Up Mapping of Interest Systems', Political Studies.

Beyers, Jan, and Bart Kerremans (2007). 'Critical Resource Dependencies and the Europeanization of Domestic Interest Groups', Journal of European Public Policy, $14: 3,460-81$.

Beyers, Jan, Rainer Eising, and William Maloney (2008). 'Researching Interest Group Politics in Europe and Elsewhere: Much We Study, Little We Know?', West European Politics, 31:6, 1103-28.

Bouwen, Pieter (2004). 'Exchanging Access Goods for Access: A Comparative Study of Business Lobbying in the European Union Institutions', European Journal of Political Research, 43:3, 337-69.

Braun, Caelesta (2012). 'The Captive or the Broker? Explaining Public Agency-Interest Group Interactions', Governance, 25:2, 291-314.

Braun, Caelesta (2015). 'Lobbying as a Leveraged Act: on Resource Dependencies and Lobby Presence', in David Lowery, Virginia Gray, and Darren Halpin (eds.), The Organizational Ecology of Interest Communities: An Assessment and Agenda. London: Palgrave MacMillan, 137-55. 
Coen, David, and Alexander Katsaitis (2013). 'Chameleon Pluralism in the EU: An Empirical Study of the European Commission Interest Group Density and Diversity across Policy Domains', Journal of European Public Policy, 20:8, 1104-19.

Daugbjerg, Carsten, Bert Fraussen, and Darren Halpin (2017). 'Interest Groups and Policy Capacity: Modes of Engagement, Policy Goods and Networks', in: Wu Xun, Michael Howlett, and Michael Ramesh (eds.), Policy Capacity: State and Societal Perspectives. London: Palgrave Macmillan, Chapter 17.

De Bièvre, Dirk, Arlo Poletti, and Marcel Hanegraaff (2015). 'WTO Judicial Politics and EU Trade Policy: Business Associations as Vessels of Special Interest?', British Journal of Politics and International Relations, Online first, June 1, 2016.

De Bruycker, Iskander, Marcel Hanegraaff, and Joost Berkhout (2016). 'The Paradox of Collective Action', Paper prepared for the ECPR General Conference, Prague, 5-8 September.

Dür, Andreas, Patrick Bernhagen, and David Marshall (2015). 'Interest Group Success in the European Union: When (and Why) does Business Lose?', Comparative Political Studies, 48:8, 951-83.

Eising, Rainer (2004). 'Multilevel Governance and Business Interests in the European Union', Governance, 17:2, 211-45.

Eising, Rainer (2007). 'The Access of Business Interests to EU Institutions: Towards Elite Pluralism?', Journal of European Public Policy, 14:3, 384-403.

European Commission (2001). European Governance - A White Paper. Brussels: Commission of the European Communities, COM, 428-final.

Halpin, Darren, and Bert Fraussen (2017). 'Conceptualizing the Policy Engagement of Interest Groups: Involvement, Access and Prominence', European Journal of Political Research. doi:10.1111/1475-6765.12194.

Halpin, Darren, and Grant Jordan, eds. (2011). The Scale of Interest Organization in Democratic Politics: Data and Research Methods. London: Palgrave MacMillan.

Hanegraaff, Marcel (2015). 'Transnational Advocacy over Time: Business and NGO Mobilization at UN Climate Summits', Global Environmental Politics, 15:1, 83-104.

Jentges, Erik, Matthias Brändli, Patrick Donges, and Otfried Jarren (2012). 'Die Kommunikation Politischer Interessengruppen in Deutschland: Adressaten, Instrumente und Logiken', Studies in Communication | Media, 3:4, 281-409.

Keck, Margaret, and Kathryn Sikkink (1998). Activists Beyond Borders: Advocacy Networks in International Politics. New York: Cornell University Press.

Klüver, Heike (2013). Lobbying in the European Union: Interest Groups, Lobbying Coalitions, and Policy Change. Oxford: Oxford University Press.

Kohler-Koch, Beate (2013). 'Civil Society and Democracy in the EU: High Expectation under Empirical Scrutiny', in Beate Kohler-Koch, and Christine Quittkat (eds.), DeMystification of Participatory Democracy: EU Governance and Civil Society. Oxford: Oxford University Press, 1-17.

Kohler-Koch, Beate, Peter Kotzian, and Christine Quittkat (2017). 'The Multi-level Interest Representation of National Business Associations', West European Politics. doi: 10.1080/01402382.2017.1303244.

Kohler-Koch, Beate, and Vanessa Buth (2013). 'The Balancing Act of European Civil Society: Between Professionalism and Grass Roots', in Beate Kohler-Koch and Christine Quittkat (eds.), De-Mystification of Participatory Democracy: EU Governance and Civil Society. Oxford: Oxford University Press, 114-48.

Kohler-Koch, Beate, and Barbara Finke (2007). 'The Institutional Shaping of EU Civil Society Relations: A Contribution to Democracy via Participation?', Journal of Civil Society, 3:3, 205-21. 
Lowery, David, and Virginia Gray (2004). 'Bias in the Heavenly Chorus Interests in Society and before Government', Journal of Theoretical Politics, 16:1, 5-29.

Lowery, David, Frank Baumgartner, Joost Berkhout, Jeffrey Berry, Darren Halpin, and Marie Hojnacki (2015). 'Images of an Unbiased Interest Group System', Journal of European Public Policy, 22:8, 1212-31.

Mahoney, Christine (2008). Brussels versus the Beltway: Advocacy in the United States and the European Union. Washington, DC: Georgetown University Press.

Majone, Giandomenico (1998). 'Europe's 'Democratic Deficit': The Question of Standards', European Law Journal, 4:1, 5-28.

Minkoff, Debra, Silke Aisenbrey, and Jon Agnone (2008). 'Organizational Diversity in the US Advocacy Sector', Social Problems, 55:4, 525-48.

Neuendorf, Kimberly (2002). The Content Analysis Guidebook. Thousand Oaks, CA: Sage.

Offe, Claus, and Helmut Wiesenthal (1980). 'Two Logics of Collective Action: Theoretical Notes on Social Class and Organizational Form', Political Power and Social Theory, 1:1, 67-115.

Pappi, Franz, and Christian Henning (1998). 'Policy Networks: More than a Metaphor?', Journal of Theoretical Politics, 10:4, 553-75.

Pedersen, Helboe, Darren Halpin Helene, and Anne Rasmussen (2015). "Who Gives Evidence to Parliamentary Committees? A Comparative Investigation of Parliamentary Committees and their Constituencies", Journal of Legislative Studies, 21:3, 408-27.

Perez-Solorzano Borragan, Nieves, and Stijn Smismans (2012). 'Representativeness: A Tool to Structure Interest Intermediation in the European Union?', JCMS: Journal of Common Market Studies, 50:3, 403-21.

Rasmussen, Anne, and Brendan Carroll (2013). 'Determinants of Upper-Class Dominance in the Heavenly Chorus: Lessons from European Union Online Consultations', British Journal of Political Science, 44:2, 445-59.

Schattschneider, Elmer Eric (1960). The Semisovereign People: A Realist's View of Democracy in America. New York: Holt, Rinehart, and Winston.

Schlesinger, Philip (1999). 'Changing Spaces of Political Communication: The Case of the European Union', Political Communication, 16:3, 263-79.

Schlozman, Kay, Philip Jones, Yu Hyu Young, Traci Burch, Sidney Verba, and Henry Brady (2015). 'Louder Chorus - Same Accent: The Representation of Interests in Pressure Politics, 1981-2011', in David Lowery, Virginia Gray, and Darren Halpin (eds.), The Organization Ecology of Interest Communities: An Assessment and an Agenda. London: Palgrave MacMillan, 157-81.

Schmitter, Philippe, and Wolfgang Streeck (1999). 'The Organization of Business Interest: Studying the Associative Action of Business in Advanced Industrial Societies', MPIfG Discussion Paper 99 / 1 (org. version (1981): WZB Discussion Paper, IIM / LMP 81-13).

Streeck, Wolfgang, and Philippe Schmitter (1991). 'From National Corporatism to Transnational Pluralism: Organized Interests in the Single European Market', Politics and Society, 19:2, 133-64.

Wilson, James (1974). Political Organizations. New York: Basic Books. 


\section{Appendix. Coding scheme concerning the dimensions of representational capacity}

\begin{tabular}{|c|c|}
\hline Representational capacity & $\begin{array}{l}\text { 1. No mention of interest representation before government or through } \\
\text { creating broader awareness }\end{array}$ \\
\hline - Policy-interest scale & $\begin{array}{l}\text { 2. Interest representation is mentioned in mission statement or some- } \\
\text { where else on website, but no mention of policy-oriented activities } \\
\text { 3. Minimal policy-oriented activities reported, such as: 'the association } \\
\text { land owners find sustainable forest management important' } \\
\text { 4. One or two concrete policy-oriented activities found, including moni- } \\
\text { toring and information-oriented activities } \\
\text { 5. A separate section of the website reports on policy campaigns and } \\
\text { positions, or throughout the website one finds references to public } \\
\text { policy, including indirect strategies such as creating awareness } \\
\text { 6. The policy section is substantial and includes several different types of } \\
\text { documents (policy statement, public campaigns, etc.) }\end{array}$ \\
\hline $\begin{array}{l}\text { Representational capacity } \\
\text { - Membership involvement } \\
\text { scale }\end{array}$ & $\begin{array}{l}\text { 1. The members only transfer money (e.g. called 'donors' or 'supporters') } \\
\text { 2. Members may have some official rights but there is no explicit refer- } \\
\text { ence to this } \\
\text { 3. Members are called 'members', and seem formally to have voting } \\
\text { rights } \\
\text { 4. Members have some opportunity to participate in the organisation, } \\
\text { such as through volunteering } \\
\text { 5. Members have several ways to participate and decision-makers have } \\
\text { a track-record within the organisation/cause } \\
\text { 6. Members fully run the organisation, also paid staff seem to be } \\
\text { selected primarily on the basis of their loyalty to the cause rather than } \\
\text { management experience (e.g. association of doctors is managed by a } \\
\text { doctor) }\end{array}$ \\
\hline
\end{tabular}




\title{
๖ OPEN ACCESS
}

\section{Cultural capital and the density of organised interests lobbying the European Parliament}

\author{
Brendan J. Carroll and Anne Rasmussen
}

\begin{abstract}
Drawing on a new dataset the article investigates a case study of the population of interest representatives lobbying the European Parliament. It examines the role of economic and cultural resources to account for the representation of organised interests from different EU member states. It adds to the existing literature on the density of organised interests by showing that in addition to economic resources, cultural capital plays a significant role in stimulating the activity of organised interests. Whether countries have a high number of organised interests in the parliament's interest group community depends on both whether they are economically prosperous and how large a share of their citizens participate in associational life. In addition, the findings demonstrate how the ranking of countries in the population of organised interests lobbying the parliament depends on the benchmark used to measure density.
\end{abstract}

During the frequent waves of negotiations about its institutional structure, the EU has often revealed an inherent tension in the balance of power between representatives from the member states in its formal bodies. As an example, the balance of seats between the member states has been a complex issue in the European Parliament (EP) (Corbett et al. 2007). ${ }^{1}$ In September 2007, when members of the European Parliament (MEPs) debated their own proposal for the redistribution of its seats, one of the two co-rapporteurs of the parliament on the matter, Mr. Lamassoure, emphasised how 'reason and logic should prevail over passion and national interest' ${ }^{2}$ on an issue which he later characterised as 'a hot potato.' The question of how the EP should be composed is important in light of the substantial increase in its powers over the last decades. The EP has gone from being a consultative body with limited powers to acting as a co-legislator in the vast share of EU legislative areas (Burns et al. 2013; Lehmann 2009).

This is an Open Access article distributed under the terms of the Creative Commons Attribution-NonCommercialNoDerivatives License (http://creativecommons.org/licenses/by-nc-nd/4.0/), which permits non-commercial re-use, distribution, and reproduction in any medium, provided the original work is properly cited, and is not altered, transformed, or built upon in any way. 
The expansion of EP power has made it a more attractive venue for lobbyists and has given rise to increased attention from the interest group community (e.g. Kohler-Koch 1997; Marshall 2010; Rasmussen 2015; Wessels 1999). The relative emphasis on lobbying the EP as opposed to other venues has risen. Studies of companies have shown that these devote an increasing share of their resources towards lobbying the EP (Coen 1997). Of the 8462 actors listed in the EU Transparency Register in April 2015, 2044 held one or more passes to the EP. ${ }^{4}$ This is a high share given that many of the organised interests listed in the Transparency Register are unlikely to have a permanent physical presence in Brussels.

Organised interests lobbying the EP exist in many forms including membership associations, firms, think tanks and national institutions (Baroni et al. 2014). There are various ways of classifying the interests they represent. Some actors can be grouped according to functional, substantive interests (such as producers, consumers or labour) whereas for other types of actors such a classification is harder to make. At the same time, a substantial share of the organised interests present in Brussels have their roots in different member states (Eising et al. 2017; Rasmussen and Gross 2015; Wonka et al. 2010). Yet, to date, research on the population density of organised interests in the EU has focused on explaining variation in the number of organised interests between different policy issues and areas (Broscheid and Coen 2007; Coen and Katsaitis 2013; Rasmussen et al. 2014) as well as between economic and social sectors of group activity (Berkhout et al. 2015; Messer et al. 2011) rather than between countries.

Our analysis makes two important contributions: we perform the first systematic study of the population density of interest groups from different member states lobbying the EP. We pay attention to their absolute number as well as to relative measures of the density of these organised interests. Regarding the latter, we place the national interest organisations in relation to different country-specific benchmarks (see also Gray and Lowery 2000) such as the size of the national economy, the size of the national population and the country's number of seats in the EP. These benchmarks help us to link the examination of interest group density to the wider study of descriptive representation in the EP. ${ }^{5}$ Second, we add to existing work on the density of organised interests in the US and the EU (for a recent review, see Berkhout et al. 2015) by considering not only economic but also cultural resources as a source of the density of an interest group population. Relying on the social capital literature (see e.g. Andrews 2011; Boix and Posner 1998; Putnam 1993; Tavits 2006) we develop our argument that cultural resources also serve as important push factors for the mobilisation of organised interests vis-à-vis the EP. We hypothesise that a strong national associational culture stimulates the volume of national, organised interests active in the EP. Our analysis is based on a new dataset of the population of organised interests registered to lobby the EP between 2005 and 2009. The data was coded in the European-wide INTEREURO project (Beyers et al. 2014). 
It is essential to understand how well represented national interest groups are in the EU system in an institution such as the EP, which is a co-legislator in the vast share of the policies dealt with by the EU. Moreover, it is widely recognised that organised interests play a particularly prominent role in the EU. In the EU's political system, political parties do not play the same role as in the member states when it comes to transmitting public views to decision-makers (Lindberg et al. 2008). Instead there is a high emphasis on securing legitimacy through the involvement of civil society whose participation is actively encouraged and financially supported by the EU institutions. ${ }^{6}$ Clearly, organised interests need to respond to a range of different principals apart from their national constituency as a whole: Organised interests typically represent different substantive interests irrespective of which country they come from. At the same time, territorial interests are also important in the complex EU construction, which is still far from being an actual state. Rather it forms a political system in which national divisions between countries with different attitudes towards European integration play a role in many political discussions alongside other types of conflicts (Marks and Steenbergen 2004).

Our findings underline the value of considering the number of organised interests in relation to different benchmarks. These help us to obtain a more nuanced picture of the density of different national populations of organised interests lobbying the EP. Our findings show important similarities between various countries in the relative density of their organised interests even though the choice of benchmark also affects the ranking of a given country. Most importantly, the old member states have a significantly higher interest group density per seat in the EP than younger member states. Moreover, in line with our expectations we find evidence that not only economic but also cultural resources play a role in accounting for the number of national organised interests lobbying the EP. Both countries with a large economy as well as those with a large share of the population active in voluntary associations have a high number of interest representatives lobbying the EP. These findings have important implications for understanding national representation in EU lobbying as well as for future theorising about the density of organised interests.

\section{Lobbying the European Parliament}

As already mentioned, the strengthened role of the EP and its increased relevance as a venue for organised interests active in EU lobbying has not gone unnoticed in the literature (Lehmann 2009). Studies of EP lobbying have for example examined the access of organised interests to the EP and other institutions (see e.g. Bouwen 2004; Dür and Mateo 2012; Eising 2007), the strategies of organised interests with respect to who to lobby in the EP (e.g. Marshall 2010, 2015) as well as the lobbying success of organised interest groups in the EP (e.g. Baroni 2014; Rasmussen 2015). Our aim is to explain cross-national variation 
in the number of organised interests lobbying the EP. Our focus is thus not on explaining which elements at the level of individual, national groups determine whether they decide to actively lobby the EP (see e.g. Dür and Mateo 2012; Eising 2007) but in understanding country-level differences in the representation of organised interests at a higher level of aggregation.

Representation is a complex phenomenon involving many different dimensions, such as: are elected politicians representative in terms of descriptive characteristics (e.g. race, gender)? Do they enact policies in line with the substantive interests of their constituencies (see Pitkin 1967)? We are interested in the descriptive representation of different geographical areas, or what has been referred as 'territorial representation' in work comparing the opinion of voters and MEPs in different EU countries (Marsh and Wessels 1997). In the EU literature on interest representation, a distinction has sometimes been made between studies examining 'territorial interest representation' of EU subnational entities (regions and localities) and those examining 'functional interest representation' of different substantive interests such as business versus labour (Knodt 2011). These different forms of interest representation have been portrayed as occurring in different types of arenas even if there is not necessarily a strong cleavage between functional and territorial interest representation in practice. In fact, many commonalities can be found in the strategies of regions and interest groups (Knodt 2011; see also Tatham 2017). Therefore, we do not depart from the assumption that interest organisations always represent a specific type of interest or contribute to a specific form of representation, be it 'territorial,' 'functional' or maybe sometimes even 'party political'. Instead, organised interests may represent and align different types of interests in practice.

Understanding representation of interest representatives from the different member states in EU institutions such as the European Parliament is important in the EU which - despite sharing many attributes of a political system - is not a state (Hix and Hoyland 2011). As a result of variation in both the level of regulation and regulatory traditions across the EU member states, policy negotiations in Brussels often need to find compromises between different political parties and different national interests. In such negotiations, interest organisations not only speak on behalf of specific substantive interests but may also represent distinct national approaches to tackling a given policy issue. Therefore, organised interests of the same type - such as trade unions or business groups - from different member states do not always represent a unified front on a given issue. Similarly, MEPs from a given party group within the EP may sometimes be divided according to their national affiliation. This emphasises the need to consider how actors from different EU member states are represented in the EU, not only in the formal EU bodies but also in the population of interest representatives. Existing research makes it clear that alongside European associations, national associations continue mobilising and getting access to the EP (e.g. Bouwen 2004; Eising 2007). 


\section{Explaining variation in national groups}

We share the interest of scholars studying the density of interest groups (Gray and Lowery 2000) in modelling differences in the number of organised interests across 'aggregate units' (in our case: countries). However, we expand the focus of the existing cross-national studies. These have focused on explaining variation in the number of trade and business associations (Bischoff 2003; Coates et al. 2007) or that of interest representatives that attend the ministerial conferences of the WTO (Hanegraaff et al. 2015). The number of groups present in political venues is not only important in its own right but also because it may impact on other aspects of interest representation, such as the strategies and potential lobbying success of groups as well as the performance of the political system as a whole (Berkhout et al. 2015; Messer et al. 2011). ${ }^{7}$ Similar to work done by interest group population ecologists on the US states (Gray and Lowery 2000), we focus on the structural determinants of the activity of organised interests from different territorial entities. Our explicit focus is on how the supply of resources (or the 'area') available to groups affects the number of groups lobbying the EP. We also control for demand-side factors that might create an incentive for them to mobilise. According to Berkhout et al. (2015: 464), the EU system may be a least likely case for finding an effect of supply-side explanations given the "long causal chain between "supply" factors and the actual lobbying venue, whereas considerable support for demand-side effects were found in early work in this context (see e.g. Broscheid and Coen 2003). Moreover, we add to existing work on population ecology in interest group research by considering not only economic but also cultural resources as a factor that might affect the capacity of national groups to lobby the EP.

To begin with, the literature on organised interests contains no lack of accounts of how economic resources affect the mobilisation of individual groups. The interest group community in both the EU and elsewhere has often been accused of being 'biased' towards resourceful groups (Rasmussen and Carroll 2014; Schattschneider 1960; Schlozman 1984). Access to resources should make it easier for national interest representatives to expand the range of their lobbying activities from the national to the supranational level. Mobilising at the EU level requires resources to monitor policy-making, to design and implement strategies and to forge alliances with other stakeholders (for a similar argument related to transnational advocacy, see Hanegraaff et al. 2015). In work on the mobilisation of subnational governments in Brussels, Marks et al. (1996) speak of a 'resource push': a greater amount of financial resources facilitates EU-level activity.

In a similar way, explanations of the density of organised interests by interest group population ecologists attach high emphasis to the importance of economic factors when it comes to explaining the number of groups. Just as biological species depend on resources for their survival, the number of groups is 
expected to be constrained by the economic resources available in their environment (Berkhout et al. 2015; Gray and Lowery 2000). According to population ecology, increases in organisational constituents will result in larger populations because more constituents should make it possible for organisations to represent niches of interests that are narrower and more specific. Moreover, the number of interest groups is not only affected by the number of potential constituents (e.g. the number of firms in the case of a business association) but also by the wealth of those constituents given that better-endowed interests are more likely to mobilise in the first place (Berkhout et al. 2015).

In line with such a logic, work on the density of national trade associations has found evidence that economic development stimulates a higher number of interest groups (Bischoff 2003; Coates et al. 2007). Economic development lowers the costs of group mobilisation through better transportation and information infrastructure, which makes it easier to both form and maintain organised interests (Bischoff 2003). It also increases the total number of interests in a society through labour specialisation, product differentiation and the growing choice of products and activities that consumers with additional income possess. Our expectation is therefore that the economic resources of a country can help stimulate the activity of organised interests. However, importantly, we do not expect the relationship between economic resources and interest group density to be linear. As argued by population ecologists, decreasing returns to scale will mean that the marginal utility of additional groups will start declining at some point as more resources become available (Berkhout et al. 2015). Our first hypothesis is therefore that the number of organised interests from a country lobbying the European Parliament increases with its amount of economic resources but at a declining rate.

Yet, apart from economic resources, historical legacies and cultural traditions might also be important among the supply-side factors that stimulate the number of organised interests from a country. Putnam (1993) has for example argued that a country's legacy with respect to associational engagement may have an impact on the status of its current civil society (see also Bailer et al. 2013). Such associational activity has often been regarded as an important component of the concept of 'social capital', which is a term used to evaluate the quality of the social environment among people (Coleman 1990: 304; Putnam 1995). The idea is that citizens acquire social capital through their interactions and networks with others. This social capital may help them achieve their goals more effectively and have a positive impact on societal governance more generally. Even if the usage of the concept of social capital in the recent literature has not escaped criticism (e.g. Jackman and Miller 1998), several studies have provided evidence of a link between social capital and the effectiveness of public governance (e.g. Andrews 2011; Cusack 1999; Putnam 1993). Rather than referring to the general concept of social capital, which aggregates many different sub-dimensions (e.g. Putnam 2000), we look directly at support for voluntary associations. 
Such support and engagement in civil society organisations can serve as a foundation for the maintenance of a strong lobbying presence not only at the national but also the supranational level. It may for example increase the level of political sophistication within a given society, which will in turn help overcome potential collective action problems and ensure that citizen demands are articulated (Boix and Posner 1998; Putnam 1993). According to Putnam (1993: 183), 'Where norms and networks of civic engagement are lacking, the outlook for collective action appears bleak'. A higher stock of associational capital makes it more likely that collective action takes place resulting in a higher degree of policy activism by which citizens and organised interests aim to monitor and influence government (Andrews 2011; Tavits 2006). The idea is that participation in voluntary association stimulates a learning process in which national actors become more exposed to information and the benefits of actively engaging in policy activism such as EP lobbying. In a study on the mobilisation of subnational governments in Brussels, Marks et al. use a similar line of reasoning. They argue 'that the skills and habit developed within a strong associational culture may spill over into public life' (Marks et al. 1996: 169) and exert a positive influence on the likelihood of having regional representation in Brussels. Accordingly, the regions with the strongest associational culture should be the ones most visible in the lobbying landscape. Even if their data requires them to test this argument via an indirect proxy (the share of the workforce in the industrial sector), they find considerable support for the idea. Following the argumentation above, our second hypothesis is that there is a positive relationship between the share of the public active in voluntary associations and the number of organised interests from a country lobbying the European Parliament.

\section{Data and variables}

To examine the density of interest group representatives from different countries in the EP, we rely on a dataset collected for INTEREURO, an international research project examining multiple facets of interest group lobbying in the $\mathrm{EU}$ and its member states (Beyers et al. 2014). The population consists of all organisations that held a 'doorpass' to access the EP building for any period of time between 2005 and 2009. Given our focus on national groups lobbying the $\mathrm{EP}$, using a register for this institution only is key for us. The data for a five-year period allows us also to control for short-term fluctuations in the representation of organised interests from different countries. Importantly, this period was not marked by radical changes in the use of the register itself in comparison to the EU's Transparency Register. The latter has experienced several changes in the rules guiding registration and witnessed a steep increase in the number of registrants ever since its introduction in 2011. Relying on the INTEREURO coded dataset also gives us the distinct advantage that we do not have to rely on 
self-reported information about the groups that has been the subject of criticism (ALTER-EU 2012). Moreover, our INTEREURO doorpass data enable us to single out groups by using the coded information about the scope of interest that they represent. ${ }^{8}$

From our dataset we select all organised interests that are headquartered in an EU member state and represent national or subnational interests. To create our dependent variable, we aggregate numbers of groups across the entire five-year period to smooth out marginal differences over time and to construct density measures based on the largest possible number of organised interests. The number of groups varies only marginally over time as our data are for a relatively short time period. The main variation is thus cross-national and not time-varying, such that cross-sectional variation is the main focus of our explanation. ${ }^{9}$

In total, 693 business associations, firms, citizen groups, labour and professional associations, institutions, national authorities and other actors from the member states are present in the registry for this period. Rather than restricting the term 'organised interest' to membership associations, we are thus employing a broader, behavioural definition, which classifies actors 'based on their observable, policy related activities' (Baroni et al. 2014: 142; see also Beyers et al. 2008). Among these groups, 112 are located in Belgium, whose capital Brussels hosts not only central government authorities but also the EP itself, giving its organised interests a unique advantage in terms of access to this institution. Because of this exceptionalism, we exclude Belgium from the analyses that follow.

The first part of our empirical analysis explores national differences in density. Rather than only considering the raw number of groups, we also examine relative density measures, thus placing the number of groups in relation to different benchmarks. Already when Gray and Lowery published their seminal book they emphasised that:

While a raw number of interest organizations provides a starting point for measuring interest population density, it is not obvious that by itself it is an adequate indicator. Density is a relational concept ... Therefore, numbers of organizations must be compared to some frame of reference to give the indicator meaning in terms of the underlying concept of density. (Gray and Lowery 2000: 86)

We therefore compare different density measures such as: (a) absolute density (i.e. the number of groups per country); (2) GDP per organised interest; (3) citizens per organised interest; and (4) EP seats per organised interest. This helps us to give more nuanced answers to the broader question of representation to which our work relates.

The second part of the analysis aims at explaining variation in density between countries. Our main goal is to examine the explanatory power of cultural versus economic resources. Following Gray and Lowery (2000) we model the absolute number of organised interests in this part of our article. According to Gray and Lowery, such a strategy is advantageous given that relative density measures (such as citizens per organised interest) are not 
natural entities that act or are acted on directly. They are products or artifacts of what happens to numbers of interest organizations in relation to something else ... Therefore, when our focus shifts to explanation ... attention will be given exclusively to interest organization numbers. (Gray and Lowery 2000: 107-8)

We model the differences in density by regressing the total count of organised interests on two main independent variables that capture economic and cultural resources, respectively, and controlling for alternative explanations. With the exception of our measure of cultural resources (described below), we average the independent variables over the 2005-2009 period.

For economic resources, we measure the size of a country's economy by its GDP (obtained from Eurostat). Because we do not expect a linear relationship between economic size and density but instead one that reflects diminishing marginal returns to economic size (that is, the effect of wealth on density remains positive but diminishes in magnitude with wealth), we take the logarithm of this variable.

For cultural resources we use a measure of associational membership adapted from Norris (2003). We construct the measure based on a question included irregularly in Eurobarometer surveys. Respondents are asked to select from a list of 14 types of voluntary membership organisations ${ }^{10}$ (and one residual choice for membership organisations not included in the 14) the ones to which they belong. We then take the share of respondents who indicate membership in any one category of voluntary organisations. Using survey weights, we finally determine the share of citizens in each member state that belong to such organisations. Within our time period from 2005 to 2009, only Eurobarometer 66.3 (fieldwork conducted in 2006) includes the question, so we construct our measure from this survey alone. Among the 26 member states used in the analysis, the average national share of individuals participating in voluntary organisations is $31 \%$ with a low of $10 \%$ (Bulgaria) and a high of $60 \%$ (Austria). ${ }^{11}$

As mentioned, the number of national groups may not only be a question of the capacity but also the incentive of groups from a given country to seek rents from mobilising. Hence, organised interests from some countries may have a higher incentive to be active in the European Parliament than others. Therefore, we control for two additional factors that represent incentives for organised interests to mobilise at the EP. The first represents EU expenditures in each of the member states and measures the direct transfers to each country (in billions of euros), obtained from the website of the Directorate-General for Budget. The amount of EU fiscal transfers such as transfers of structural funds or agricultural subsidies to different member states varies so that some are greater beneficiaries of EU funds than others. This might provide interest groups from these countries with a greater incentive to maintain a strong presence in Brussels. The second reflects a country's reliance on trade within the EU and outside it. Groups from countries with high trade integration may be more 'energised' to get involved in lobbying the EU institutions since the 
EU regulatory environment ultimately affects them more (Rasmussen and Alexandrova 2012) (for a similar argument, see also Broscheid and Coen 2007; Cram 1998; Richardson and Mazey 2015). The internal market policies of the EU will be likely to draw national, organised interests from countries that benefit from trade within the EU. EU customs and competition policies will provide incentives for groups to mobilise from countries that benefit from external trade. Hence we measure trade reliance as the total value of imports and exports both with member states and with non-member states standardised by a country's GDP.

\section{Density of national, organised interests}

Table 1 shows cross-national differences in the density of organised interests from the EP doorpass registry using four alternative measures. The first is a simple count of the number of organised interests per country, and the table ranks the countries according to this measure (which will be the dependent variable in the next section). Germany has the most organised interests in the

Table 1. Interest groups in the European Parliament registry per country.

\begin{tabular}{|c|c|c|c|c|c|c|c|c|}
\hline Country & Count & Rank & $\begin{array}{c}\text { GDP/group } \\
\text { (euro } \\
\text { millions) }\end{array}$ & Rank & $\begin{array}{c}\text { Population/ } \\
\text { group } \\
\text { (thousands) }\end{array}$ & Rank & $\begin{array}{l}\text { EP seats/ } \\
\text { group }\end{array}$ & Rank \\
\hline Germany & 148 & 1 & 3991 & 8 & 556 & 9 & 0.67 & 3 \\
\hline Belgium & 112 & 2 & 734 & 1 & 95 & 1 & 0.21 & 1 \\
\hline France & 95 & 3 & 4854 & 15 & 669 & 12 & 0.81 & 4 \\
\hline Italy & 89 & 4 & 4258 & 10 & 665 & 11 & 0.86 & 5 \\
\hline $\begin{array}{l}\text { United } \\
\text { Kingdom }\end{array}$ & 74 & 5 & 6328 & 17 & 825 & 13 & 1.04 & 8 \\
\hline Netherlands & 43 & 6 & 3248 & 4 & 381 & 4 & 0.62 & 2 \\
\hline Spain & 36 & 7 & 7059 & 18 & 1244 & 15 & 1.48 & 10 \\
\hline Sweden & 19 & 8 & 4160 & 9 & 480 & 7 & 0.99 & 7 \\
\hline Austria & 18 & 9 & 3715 & 6 & 460 & 6 & 0.99 & 6 \\
\hline Denmark & 13 & 10 & 4278 & 11 & 420 & 5 & 1.06 & 9 \\
\hline Finland & 8 & 11 & 5381 & 16 & 660 & 10 & 1.73 & 11 \\
\hline Romania & 6 & 12 & 4669 & 14 & 3495 & 20 & 3.43 & 16 \\
\hline Hungary & 6 & 13 & 3958 & 7 & 1677 & 17 & 3.93 & 17 \\
\hline Ireland & 5 & 14 & 8727 & 19 & 866 & 14 & 2.56 & 13 \\
\hline Poland & 5 & 15 & 15,032 & 22 & 7628 & 22 & 10.64 & 21 \\
\hline Slovenia & 4 & 16 & 2088 & 3 & 503 & 8 & 1.75 & 12 \\
\hline Greece & 4 & 17 & 13,614 & 21 & 2793 & 19 & 5.90 & 18 \\
\hline Cyprus & 2 & 18 & 1954 & 2 & 381 & 3 & 3.00 & 14 \\
\hline Luxembourg & 2 & 19 & 4366 & 12 & 238 & 2 & 3.00 & 15 \\
\hline Estonia & 1 & 20 & 3542 & 5 & 1345 & 16 & 6.00 & 19 \\
\hline Latvia & 1 & 21 & 4567 & 13 & 2208 & 18 & 8.80 & 20 \\
\hline Slovakia & 1 & 22 & 13,261 & 20 & 5375 & 21 & 13.80 & 22 \\
\hline $\begin{array}{l}\text { Czech } \\
\text { Republic }\end{array}$ & 1 & 23 & 32,591 & 23 & 10,289 & 23 & 23.60 & 23 \\
\hline Bulgaria & 0 & & & & & & & \\
\hline Lithuania & 0 & & & & & & & \\
\hline Malta & 0 & & & & & & & \\
\hline Portugal & 0 & & & & & & & \\
\hline
\end{tabular}


register with a total of 148, while Bulgaria, Lithuania, Malta and Portugal had none during the examined period. The average number of organised interests per country is 22.4 (including Belgium it is 25.7), but most countries have fewer organised interests than the mean. The standard deviation of 37.7 is well above the mean, indicating a high variability.

The remaining columns of Table 1 show the density of organised interests in the EP in relation to three alternative benchmarks. The analysis is limited to those countries with at least one organised interest present. Beside each of these benchmarks is a ranking of each country in order of descending density. As the benchmarks all measure density inversely, the ranking is in ascending order of the values for each country.

We start by looking at GDP in relation to groups. Interest group research often emphasises how economic resources serve as an important basis of group activity (Schattschneider 1960; Schlozman and Tierney 1986). As a result, Gray and Lowery (2000) suggest using the size of the economy as a benchmark when assessing the number of groups. In order to do so, the column labelled GDP represents the gross domestic product in millions of euros per organised interest. It relies on the average GDP for each country across the five-year period for its construction. This measure of 'representational economic density' (Gray and Lowery 2000: 89) is an inverse measure of density as higher values indicate fewer groups relative to the size of a country's economy. It ranges from $€ 734$ million per group (Belgium) to $€ 32,591$ million per group (Czech Republic) with a means of $€ 6799$ and $€ 7075$ million per group with and without Belgium, respectively. Excluding Belgium, the densest countries with respect to this benchmark are a diverse set that includes countries with few organised interests (Cyprus and Slovenia) and one with a relatively high number of interest groups (the Netherlands).

The next benchmark we use is population. It measures the number of inhabitants (in thousands) in a country per organised interest (with population averaged across the five-year period). As with the previous measure it is an inverse density measure, with lower values indicating fewer inhabitants per group and hence higher density. Density using this benchmark ranges from 95,000 inhabitants per group for Belgium (the next highest is Luxembourg with 238,000 inhabitants per group) to over 10 million inhabitants per group present in the EP for the Czech Republic. This measure has an average of 1,881,000 inhabitants per group (or 1,962,000 inhabitants per group excluding Belgium). Countries that rank high on representational economic density tend to rank high on this measure as well, but there are some notable exceptions. Hungary drops from the seventh position in terms of GDP to the seventeenth position in terms of population; Estonia drops from the fifth to the sixteenth position and Luxembourg rises from the twelfth to the second position.

Finally, the last benchmark we use concerns representational political density and looks at the relationship between the number of organised interests 
from a country and its number of official MEPs in the European Parliament. The measure - calculated as the number of EP seats per organised interest - is also a measure of inverse density. On the one hand, the densest member states with respect to this benchmark are also the oldest member states: Belgium, the Netherlands, Germany, France and Italy are five of the six founding members of the European Economic Community. On the other hand, the least dense member states are all new member states (the Czech Republic, Slovakia, Poland, Latvia and Estonia occupy the highest ranks for this measure). The measure ranges from 0.2 (or 0.7 if Belgium is excluded) to $23.6 \mathrm{EP}$ seats per organised interest with an average of 4.2 and 4.4 with and without Belgium, respectively.

Thus although there are similarities in the ranking of countries when using these alternative benchmarks, the differences that remain suggest that assessments of the degree to which countries are represented by organised interests lobbying the EP depend to some extent on the chosen criterion of representation. Given the high correlation between GDP and population in EU countries, the difference in ranking between economic representation and representation by population is relatively small, with wealthy, smaller countries and relatively poorer but larger countries driving the differences observed. The departure from pure proportionality in EP seats (Delgado-Márquez et al. 2013) means that the ranking of EP seats per group differs from that of population per group. Remarkably, a pattern emerges for the former that follows the duration of EU membership.

\section{Variation in national numbers of organised interests}

As a next step, we now explore variation in the number of organised interests in the EP doorpass registry from 2005 to 2009 for $26 \mathrm{EU}$ countries (every member state during that period except Belgium). As our dependent variable

Table 2. Negative binomial regression explaining density.

\begin{tabular}{lcccc}
\hline & $(1)$ & $(2)$ & $(3)$ & $(4)$ \\
\hline Log of GDP & $1.061^{* * *}$ & & $1.064^{* * *}$ & $1.038^{* * *}$ \\
Associational membership & $(0.084)$ & & $(0.045)$ & $(0.091)$ \\
& & $0.059^{* * *}$ & $0.020^{* * *}$ & $0.020^{* * *}$ \\
Direct transfers (euro billions) & & $(0.020)$ & $(0.004)$ & $(0.005)$ \\
& & & & 0.009 \\
Trade & & & & $(0.020)$ \\
& & & & 0.015 \\
Constant & $-23.973^{* * *}$ & 1.009 & $-24.789^{* * *}$ & $-24.069)$ \\
McFadden pseudo-R2 & $(2.138)$ & $(0.714)$ & $(1.195)$ & $(2.224)$ \\
Observations & 0.26 & 0.03 & 0.34 & 0.34 \\
Log Likelihood & 26 & 26 & 26 & 26 \\
$\Theta$ & -74.556 & -97.345 & -65.994 & -65.878 \\
& 6.284 & $0.451^{* * *}$ & 462.840 & 381.521 \\
Akaike Inf. Crit. & $(4.050)$ & $(0.122)$ & $(1756.730)$ & $(1184.140)$ \\
& 153.113 & 198.689 & 137.989 & 141.755 \\
\hline
\end{tabular}

Note: $p<0.1 ;{ }^{* *} p<0.05 \% ; * * 0<0.01$. 
is an overdispersed count of the number of organised interests, we estimate these models in Table 2 using negative binomial regressions. Because the raw coefficients of negative binomial regression models do not have a straightforward interpretation, we include the exponentiated coefficients in Table 3 . The first model is a bivariate regression model of the number of organised interests on the logarithm of a country's GDP, the independent variable that represents a country's economic resources. The effect of this variable on density is as expected: a larger economy is associated with a higher density $(p<0.01)$. The

Table 3. Negative binomial regression explaining density (exponentiated coefficients).

\begin{tabular}{lcccc}
\hline & $(1)$ & $(2)$ & $(3)$ & $(4)$ \\
\hline Log of GDP & 2.890 & & 2.898 & 2.823 \\
& $(0.084)$ & & $(0.045)$ & $(0.091)$ \\
Associational membership & & 1.060 & 1.020 & 1.020 \\
& & $(0.020)$ & $(0.004)$ & $(0.005)$ \\
Direct transfers (euro billions) & & & & 1.009 \\
& & & & $(0.020)$ \\
Trade & & & & 1.015 \\
& 0.000 & 2.744 & 0.000 & $0.069)$ \\
Constant & $(2.138)$ & $(0.714)$ & $(1.195)$ & $(2.224)$ \\
& & & &
\end{tabular}

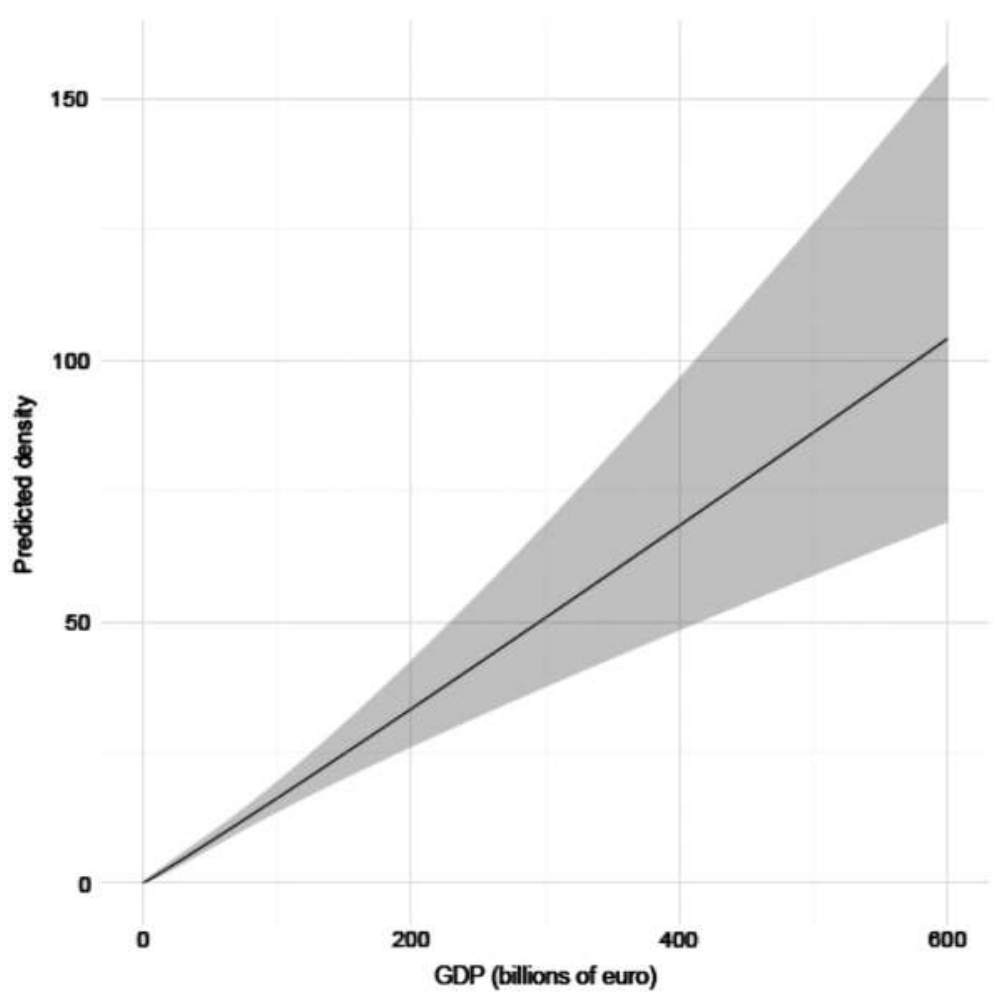

Figure 1. Plot of predicted density vs. GDP. 
pseudo- $\mathrm{R}^{2}$ is relatively high for this model $(0.26)$, indicating that economic resources are a very strong predictor of density.

The second model is also bivariate and uses instead the variable that represents a country's cultural resources. Its effect is as hypothesised: a greater share of individuals who participate in one or more voluntary associations is associated with a higher density $(p<0.01)$. Although the variable is significant, the model fit (pseudo- $R^{2}=0.03$ ) does not reach the level observed in Model 1. In Model 3 we combine the two main variables whose effects remain significant. Note that the correlation between associational membership and the logarithm of GDP is moderate $(r=0.35)$ but the effect of both variables are significant. Finally, Model 4 introduces controls for EU direct transfers and trade dependence. Both variables are correlated with economic resources, justifying their inclusion as control variables. ${ }^{12}$ Neither of them are significant but the variables representing economic and cultural resources are robust to this specification (for both variables, $p<0.01$ ).

Table 3 allows for a more intuitive substantive interpretation of the coefficients in the negative binomial models. When the coefficient from a negative

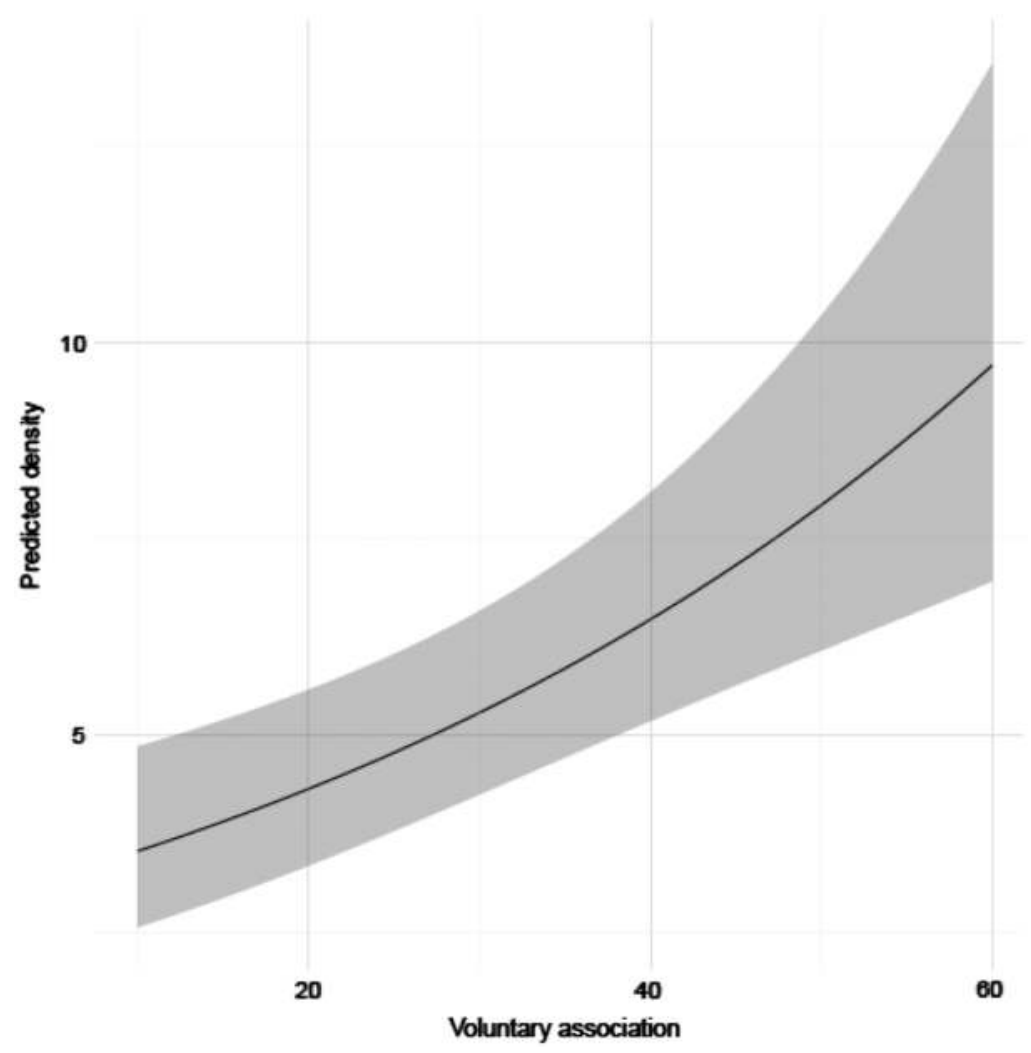

Figure 2. Plot of predicted density vs. voluntary association. 
binomial model is exponentiated, the resulting value (referred to in some contexts as the incidence rate ratio) can be interpreted as the marginal factor change in the dependent variable for a one-unit change in the independent variable. Increasing the logarithm of a country's GDP by one increases the expected density by a factor of nearly three in the three models in which that variable is present. The effect of a change in the logarithm of a country's GDP is in itself not substantively meaningful, so Figure 1 plots the expected number of organised interests for changes in raw GDP along with the 95\% confidence interval and with all other variables held constant at their means. The figures underline the substantial effect of GDP on the predicted number of groups as GDP moves within its observed range.

Considering cultural resources, according to Table 3 , a one percentage point increase in the proportion of individuals who participate in national associational life increases the expected density of groups present in the EP by a factor of 1.02 (Models 3 and 4). Figure 2 plots the expected number of organised interests for changes in this variable along with its $95 \%$ confidence interval and shows a modest increase in the predicted density across the observed range of this variable.

\section{Conclusion}

Even if interest groups are widely perceived as playing a crucial role in European governance and may represent both territorial and functional interests, existing interest group research has paid little attention to the descriptive representation of organised interests from different member states. Focusing on the case of the EP and relying on a new, unique dataset of actors registered to lobby this institution we conduct a comparative study of the density of national organised interests. We first argue that density is a relational concept and show how the density rank is affected by the benchmark employed. Countries with a high number of interest groups per MEP are among the oldest members of the EU and not necessarily the same ones as those that score highest when we examine the number of organised interests in relation to the size of the economy or the size of the population.

Second, we present a systematic explanation of the number of organised interests from different member states in the lobbying community of the EP. We focus on those factors which might affect the capacity of national organised interests to be represented in the EP lobbying community and control for factors that might affect their incentives to mobilise. In contrast to existing studies of the density of organised interests we draw specific attention to not only economic but also cultural resources.

Even if it has been argued that the EU might be a least likely case for finding strong support that supply-side factors affect density, we find strong support that not only economic but also cultural resources affect the number of 
organised interests from a country. Both the size of the national economy as well as the level of organisational engagement of the population are highly significant when it comes to explaining variation in the national number of interest groups. That the number of groups in the EP is constrained by the economic resources available in the environment in which they operate delivers strong support for the work of interest group population ecologists (e.g. Berkhout et al. 2015; Gray and Lowery 2000). We add to this work by emphasising the role which cultural resources play as a foundation for the maintenance of a strong lobbying presence at the supranational level. Citizens' associational engagement might help to overcome collective action problems of mobilising and stimulate learning processes that help organised interests to develop an effective supranational lobbying presence.

Importantly, the reason many countries do not have a strong presence of interest groups in the EP is therefore not only related to low levels of economic resources but also to the fact that they have a small engagement in organised civil society to begin with. This issue is relevant in the new Eastern and Central European member states that do not have the same tradition of civil society involvement as many older Western European member states (see also Cekik 2017). For them, a lobbying presence in Brussels is unlikely to result from increasing trade and fiscal transfers as long as their civil society engagement remains weak. Strong trade integration into the EU and fiscal transfers will still be beneficial for their economies but will not in themselves stimulate stronger involvement in EU lobbying.

There is potential to scrutinise the explanatory potential of associational engagement further in future work on interest group density when additional interest group population data are coded and when more associational engagement data from cross-national surveys on the EU member states become available. Future research should also expand our study of national differences in organised interests in the EP to other lobbying venues. Moreover, even if research at the national level of lobbying in several arenas or venues (e.g. Binderkrantz et al. 2015) leads us to expect that there is likely to be a high correlation between the number of national groups lobbying the EP and other venues, there is potential to extend our approach to other venues for EU lobbying. Examining the determinants of having a strong lobbying presence is particularly important in the European Union, which is designed in such a way that it is highly dependent on interest representatives from its different member states to secure input legitimacy.

\section{Notes}

1. http://europa.eu/legislation_summaries/institutional_affairs/treaties/lisbon_ treaty/ai0010_en.htm (accessed 20 March 2015).

2. http://www.europarl.europa.eu/sides/getDoc.do?language=EN\&type=IM-PRE SS\&reference=20070910BKG10267 (accessed 22 March 2015). 
3. http://www.europarl.europa.eu/sides/getDoc.do?pubRef=-//EP//TEXT+IM-PR ESS+20071008IPR11353+0+DOC+XML+V0//EN (accessed 22 March 2015).

4. http://ec.europa.eu/transparencyregister/public/homePage.do? redir=false\& locale=en (accessed 24 April 2015).

5. Focusing on the EP has the advantage that it enables us to look at country-level representation not only with respect to benchmarks for the size of the economy and population but also with respect to representatives from a country in the European Parliament.

6. http://ec.europa.eu/transparency/civil_society/general_overview_en.htm\#9 (accessed 22 March 2015).

7. There is disagreement on whether a higher number of groups impact on governmental performance in a positive or negative way. According to 'pluralists', a higher number of groups might help ensure a smoother transmission of public preferences to policy-makers whereas another prominent view expects a higher number of groups to increase the likelihood that policies are biased away from the interest of the median voter (for a review of this literature, see Rasmussen et al. 2014).

8. The downside to using the EP doorpass data for 2005 to 2009 is that the population data are not as up-to-date as in the Transparency Register. However, because questions about associational engagement have not been asked in recent Eurobarometer surveys, we could not relate this variable to the latest version of the Transparency data.

9. Another important reason for not exploiting the time dimension in the EP data between 2005 and 2009 is that that we do not have yearly measures of associational engagement for the period.

10. These include recreational organisations (sports or outdoor clubs); education, arts, music or cultural associations; trade unions; business or professional organisations; consumer organisations; international organisations; organisations for environmental protection or animal rights; charity or social aid organisations; leisure associations for the elderly; organisations for the defence of elderly rights; religious or church organisations; political parties or organisations; organisations defending the interests of patients and/or the disabled; and other interest groups for specific causes such as women, people with specific sexual orientations, or local issues.

11. In a related study, Messer et al. (2011) use the number of EU citizens active in groups related to a social policy area (or 'guild') to measure the potential number of constituents for groups in the area active in EU lobbying, which they expect to be positively related to actual numbers of groups. Instead we use the overall share of associational engagement to measure the cultural capital of a country. What matters to us is therefore the relative support for associations in the electorate rather than absolute number of citizens participating in groups.

12. By this token, population should also be included as a control variable, but the very high degree of correlation between population and GDP in EU countries introduces significant multicollinearity to models containing both variables. Because of the likely effect of length of EU membership on density and its moderate correlation with associational engagement, this variable might also be included as a control variable, but the low number of observations limits the possibility for additional controls. Nevertheless, the results are robust when the length of EU membership is added to the final model. 


\section{Acknowledgements}

We would like to thank Jens Blom-Hansen, Rainer Eising, Darren Halpin, Mads Dagnis Jensen, Heike Klüver and Michael Tatham for helpful comments on previous drafts of this paper. In addition, the paper received useful feedback from the participants at the workshop on Multilevel Interest Representation in the European Union at the Ruhr University of Bochum on 28-29 April 2016, the workshop on Interest Group Populations in Comparative Perspective at the University of Hamburg on 8-9 May 2015, the 2015 Annual Meeting of the Danish Political Science Association in Kolding and the 2015 Annual Conference of the European Political Science Association in Vienna. Moreover, we are grateful for the insightful and constructive comments from our two reviewers, whose feedback was helpful in revising our contribution.

\section{Disclosure statement}

No potential conflict of interest was reported by the authors.

\section{Funding}

This work was financially supported by the Netherlands Organisation for Scientific Research [grant number 461-10-519] under the European Science Foundation [grant number 10-ECRP-008] and the Danish Council for Independent Research [grant number 0602-02642B].

\section{References}

ALTER-EU (2012). 'Dodgy Data: Time to Fix the EU's Transparency Register, available at http://www.Alter-Eu.Org/Sites/Default/Files/Documents/Dodgy-Data.Pdf (accessed 12 August 2012).

Andrews, Rhys (2011). 'Exploring the Impact of Community and Organizational Social Capital on Government Performance: Evidence from England', Political Research Quarterly, 64:4, 938-49. 
Bailer, Stefanie, Thilo Bodenstein, and V. Finn Heinrich (2013). 'Explaining the Strength of Civil Society: Evidence from Cross-Sectional Data', International Political Science Review, 34:3, 289-309.

Baroni, Laura (2014). 'Information Counts: Interest Group Success in the European Parliament', Salzburg Centre of European Union Studies, PhD-Dissertation.

Baroni, Laura, Brendan J. Carroll, Adam William Chalmers, Luz Maria Munoz Marquez, and Anne Rasmussen (2014). 'Defining and Classifying Interest Groups', Interest Groups \& Advocacy, 3:2, 141-59.

Berkhout, Joost, Brendan J. Carroll, Caelesta Braun, Adam W. Chalmers, Tine Destrooper, David Lowery, Simon Otjes, and Anne Rasmussen (2015). 'Interest Organizations Across Economic Sectors: Explaining Interest Group Density in the European Union', Journal of European Public Policy, 22:4, 462-80.

Beyers, Jan, Rainer Eising, and William Maloney (2008). 'Researching Interest Group Politics in Europe and Elsewhere: Much We Study, Little We Know?', West European Politics, 31:6, 1103-28.

Beyers, Jan, Laura Chaqués Bonafont, Andreas Dür, Rainer Eising, Danica Fink-Hafner, David Lowery, Christine Mahoney, William Maloney, and Daniel Naurin (2014). 'The Intereuro Project: Logic and Structure', Interest Groups \& Advocacy, 3:2, 126-40.

Binderkrantz, Anne Skorkjær, Peter Munk Christiansen, and Helene Helboe Pedersen (2015). 'Interest Group Access to the Bureaucracy, Parliament, and the Media', Governance, 28:1, 95-112.

Bischoff, Ivo (2003). 'Determinants of the Increase in the Number of Interest Groups in Western Democracies: Theoretical Considerations and Evidence from 21 OECD Countries', Public Choice, 114:1/2, 197-218.

Boix, Carles, and Daniel N. Posner (1998). 'Social Capital: Explaining Its Origins and Effects on Government Performance', British Journal of Political Science, 28:4, 686-93.

Bouwen, Pieter (2004). 'Exchanging Access Goods for Access: A Comparative Study of Business Lobbying in the European Union Institutions', European Journal of Political Research, 43:3, 337-69.

Broscheid, A., and D. Coen (2003). 'Insider and Outsider Lobbying of the European Commission an Informational Model of Forum Politics', European Union Politics, $4: 2,165-89$.

Broscheid, Andreas, and David Coen (2007). 'Lobbying Activity and Fora Creation in the EU: Empirically Exploring the Nature of the Policy Good', Journal of European Public Policy, 14:3, 346-65.

Burns, Charlotte, Anne Rasmussen, and Christine Reh (2013). 'Legislative Codecision and its Impact on the Political System of the European Union', Journal of European Public Policy, 20:7, 941-52.

Cekik, Aneta (2017). 'Adapting to Europe? Business Interests and Civil Society Groups in Accession Countries', West European Politics, doi: 10.1080/01402382.2017.1308696.

Coates, Dennis, Jac C. Heckelman, and Bonnie Wilson (2007). 'Determinants of Interest Group Formation', Public Choice, 133:3-4, 377-91.

Coen, David (1997). 'The Evolution of the Large Firm as a Political Actor in the European Union', Journal of European Public Policy, 4:1, 91-108.

Coen, David, and Alexander Katsaitis (2013). 'Chameleon Pluralism in the EU: An Empirical Study of the European Commission Interest Group Density and Diversity Across Policy Domains', Journal of European Public Policy, 20:8, 1104-19.

Coleman, James Samuel (1990). Foundations of Social Theory. Cambridge, MA: Harvard University Press. 
Corbett, Richard, Francis Jacobs, and Michael Shackleton (2007). The European Parliament. London: John Harper Publishing.

Cram, Laura (1998). 'The EU Institutions and Collective Action: Constructing a European Interest', in J. Greenwoord and M. Aspinwall (eds.), Collective Action in the European Union. Interests and the New Politics of Associability. London: Routledge, 63-80.

Cusack, Thomas R. (1999). 'Social Capital, Institutional Structures, and Democratic Performance: A Comparative Study of German Local Governments', European Journal of Political Research, 35:1, 1-34.

Delgado-Márquez, Blanca L., Michael Kaeding, and Antonio Palomares (2013). 'A More Balanced Composition of the European Parliament with Degressive Proportionality', European Union Politics, 14:3, 458-71.

Dür, Andreas, and Gemma Mateo (2012). "Who Lobbies the European Union? National Interest Groups in a Multilevel Polity', Journal of European Public Policy, 19:7, 969-87.

Eising, Rainer (2007). 'Institutional Context, Organizational Resources and Strategic Choices: Explaining Interest Group Access in the European Union', European Union Politics, 8:3, 329-62.

Eising, Rainer, Daniel Rasch, Danica Fink-Hafner, Mitja Hafner-Fink, Meta Novak and Patrycja Rozbicka (2017). 'Who Says What to Whom? Alignments and Arguments in EU Policy Making', West European Politics, doi: 10.1080/01402382.2017.1320175.

Gray, Virginia, and David Lowery (2000). The Population Ecology of Interest Representation. Ann Arbor: University of Michigan Press.

Hanegraaff, Marcel, Caelesta Braun, Dirk De Bièvre, and Jan Beyers (2015). 'The Domestic and Global Origins of Transnational Advocacy: Explaining Lobbying Presence During WTO Ministerial Conferences', Comparative Political Studies, 48:12, 1591-1621.

Hix, Simon, and Bjorn Hoyland (2011). The Political System of the European Union. London: Palgrave Macmillan.

Jackman, Robert W., and Ross A. Miller (1998). 'Social Capital and Politics', Annual Review of Political Science, 1:1, 47-73.

Knodt, Michèle (2011). 'Strategies of Territorial and Functional Interests: Towards a Model of European Interest Intermediation?', Journal of European Integration, 33:4, 419-35.

Kohler-Koch, Beate (1997). 'Organized Interests in the EC and the European Parliament', European Integration Online Papers (EIoP) Vol. 1 (1997) No 9, 1:9. http://eiop.or.at/ eiop/texte/1997-009a.htm

Lehmann, Wilhelm (2009). 'The European Parliament', in David, Coen and Jeremy Richardson (eds.), Lobbying the European Union. Institutions, Actors, and Issues. Oxford: Oxford University Press, 39-69.

Lindberg, Björn, Anne Rasmussen, and Andreas Warntjen (2008). 'Party Politics as Usual? The Role of Political Parties in EU Legislative Decision-Making', Journal of European Public Policy, 15:8, 1107-26.

Marks, Gary, and Marco Steenbergen, eds. (2004). European Integration and Political Conflict. Oxford: Oxford University Press.

Marks, Gary, Francois Nielsen, Leonard Ray, and Jane E. Salk (1996). 'Competencies, Cracks, and Conflicts: Regional Mobilization in the European Union', Comparative Political Studies, 29:2, 164-92.

Marsh, Michael, and Bernhard Wessels (1997). 'Territorial Representation', European Journal of Political Research, 32:2, 227-41.

Marshall, David (2010). 'Who to Lobby and when: Institutional Determinants of Interest Group Strategies in European Parliament Committees', European Union Politics, 11:4, 553-75. 
Marshall, David (2015). 'Explaining Interest Group Interactions with Party Group Members in the European Parliament: Dominant Party Groups and Coalition Formation', Journal of Common Market Studies, 53:2, 311-29.

Messer, Anne, Joost Berkhout, and David Lowery (2011). 'The Density of the EU Interest System: A Test of the ESA Model', British Journal of Political Science, 41:1, 161-90.

Norris, Pippa (2003). Democratic Phoenix: Reinventing Political Activism. Cambridge: Cambridge University Press.

Pitkin, Hanna (1967). The Concept of Representation. Berkeley: University of California Press.

Putnam, Robert D. (1993). Making Democracy Work. Civic Traditions in Modern Italy. Princeton, NJ: Princeton University Press.

Putnam, Robert D. (1995). 'Tuning in, Tuning Out: The Strange Disappearance of Social Capital in America', Political Science and Politics, 28:4, 1-20.

Putnam, Robert D. (2000). Bowling Alone: The Collapse and Revival of American Community. NewYork, NY: Simon \& Schuster.

Rasmussen, Maja Kluger (2015). 'The Battle for Influence: The Politics of Business Lobbying in the European Parliament', Journal of Common Market Studies, 53:2, 365-82.

Rasmussen, Anne, and Petya Alexandrova (2012). 'Foreign Interests Lobbying Brussels: Participation of Non-EU Members in Commission Consultations', Journal of Common Market Studies, 50:4, 614-31.

Rasmussen, Anne, and Brendan Carroll (2014). 'Determinants of Upper-Class Dominance in the Heavenly Chorus: Lessons from European Commission Online Consultations', British Journal of Political Science, 44:2, 445-59.

Rasmussen, Anne, and Vlad Gross (2015). 'Biased Access? Exploring Selection to Advisory Committees', European Political Science Review, 7:3, 343-72.

Rasmussen, Anne, Brendan Carroll, and David Lowery (2014). 'Representatives of the Public? Public Opinion and Interest Group Activity', European Journal of Political Research, 53:2, 250-68.

Richardson, Jeremy, and Sonia Mazey (2015). 'Shooting Where the Ducks Are: EU Lobbying and Institutionalized Promiscuity', in Jeremy, Richardson and Sonia Mazey (eds.), European Union. Power and Policymaking. London: Routledge, 419-40.

Schattschneider, Elmer E. (1960). The Semisovereign People. New York, NY: Holt, Rinehart, and Winston.

Schlozman, Kay Lehman (1984). 'What Accent the Heavenly Chorus? Political Equality and the American Pressure System', The Journal of Politics, 46:4, 1006-32.

Schlozman, Kay Lehman, and John T. Tierney (1986). Organized Interests and American Democracy. New York, NY: Harper and Row.

Tatham, Michaël (2017). 'Networkers, Fund-Hunters, Intermediaries, or Policy Players? The Activities of Regions in Brussels', West European Politics, doi: 10.1080/01402382.2017.1303246.

Tavits, Margit (2006). 'Making Democracy Work More? Exploring the Linkage between Social Capital and Government Performance', Political Research Quarterly, 59:2, 211-25.

Wessels, Bernhard (1999). 'European Parliament and Interest Groups', in Richard S. Katz and Bernhard Wessels (eds.), The European Parliament, National Parliaments, and European Integration. Oxford: Oxford University Press, 105-28.

Wonka, Arndt, Frank R. Baumgartner, Christine Mahoney, and Joost Berkhout (2010). 'Measuring the Size and Scope of the EU Interest Group Population', European Union Politics, 11:3, 463-76. 


\section{Index}

access: business interest associations

117-22; influence $v s .109$

accession: background 129-31; conclusions

145; contacts with EU institutions

141; data 134-5; empirical analysis

141-4; Europeanisation of interest

groups 141-4; governance importance

136-8; interest group funding 136-8;

involvement in accession process 138-9;

membership, association level 139-40;

operationalisation 134-5; overview 13,

128-9; post-communist democracies

131-4; results 136-9; variables,

dependent and explanatory 135-6

adaptation 131-2; see also accession

age and experience: of associations 144;

regions activities in Brussels 159,

161-5, 167n7

Agence Europe 26, 93

alignments and arguments: conclusions

37-8; control variables 25-6; data and research design $26,28-32$; empirical analysis $32-7$; overview $11-12,19-20$; venue selection $20-5$

Amsterdam Treaty 153

Australia 48

Austria 48

'backbenchers' 73

Belgium 204-5

Berkhout, Joost 171-89

Bernhagen, Patrick 43-62

best practices $152,163,166$

bias: avoidance of 10, 26; business bias 174-5, 181; conflict perception and venue choice 43 ; diversity $171-5$; representational 176-7; towards resourceful groups 198-9 binary logistic regression models $83 \mathrm{n} 5$

bottom-up strategies 9, 11, 177

Bouwen's information-exchange model 110-14

Brant tests 117

Braun, Caelesta 171-89

'Brexit' 61

British companies 43-62

Brussels: activities of regions 150-67; presence in 130

'Brussels bubble' 173

budget, BIAs 121

'budget-centeredness' 81

Bulgaria 157-66, 204

Bundestag see Germany

business interest associations (BIAs): access difference 117-22; conclusion 122-4; continuous efforts 109; empirical findings 116-22; multilevel lobbying pattern 116-17; multivariate analysis 117-22; operationalisation 114-16; overview 13, 108-10; parsimonious rational choice approach 110-14; research design 114-16

Carroll, Brendan J. 194-210

Cekik, Aneta 128-46

chambers of commerce 135

Christian Democrats (CDU) 76

clout, economic 112

coalitions 88, 92, 95-6, 100-2

Comité de représentants permanents (COREPER) 111

compromises, information strategies 82 conflict perception: conclusion 59-61; data and research strategy 50-3; lobbying 45-50; overview 12, 43-5; results 53-9; venue shopping $45-50$ 
Constitutional Treaty 153

contacts: with EU institutions 141; frequency of 136

corporatist systems $48-50,59-60$

cost-benefit calculations 23-4, 31-2

cross-national comparisons 8-9, 114

cross-national differences 144, 185, 203

cross-national joint positions 90

cross-national surveys 209

cross-national variation 133,159 ,

196-8, 201

'crowded' issues 181-2

cultural capital and density of interests: conclusion 208-9; data 200-3; density of interests 203-5; lobbying 196-7; overview 14, 194-6; variables 200-3; variation 198-200, 205-8

Cyprus 157-66, 204

Czech Republic 132, 204-5

decision-making level vs. working level 111 density see cultural capital and density of interests

detachment from constituents 171-89

difference of means test 76

diffuse interest groups 98

Directory of British Associations 178

diversity: across interest group systems 173-7; analysis 181-6; business bias 174-5; conclusion 187-9; data collection 178-81; design of study $177-81$; overview 14, 171-3; representational capacity $176-7$

\section{ECOSOC 141}

Eising, Rainer 1-15, 19-38, 87-103

electoral terms 112

embeddedness: accession process 132, 136; conflict perception and venue choice 48 ; contacts 111; lobbying 122 ; selective exit 90

empirical analysis and findings: accession countries 141-4; alignments and arguments 32-7; business interest associations 116-22

Estonia: accession 132; activities of regions in Brussels 157-66; density of interests 205

EUROLOB II project 11, 189n4

European Affairs Committee (EAC) 74

European directory of Public Affairs 178

European Economic and Social Committee 48-9
Europeanisation see accession

European Parliament: information strategies 66-83; lobbying 194-210

European Voice 26, 93

events per predictor variable (EPV) 98

exact logistic regressions 87-102, 103n8

exit: opposition as causes 38 ; threats of 90 ; see also selective exit

expert knowledge 23, 113

Financial Times 26, 93

Fink-Hafner, Danica 19-38

flexibility development 49

'fragmented representation' 114

France: access 122; business interest associations 114, 117-22; density of interests 205; diversity 171-89; statist system 177

Frankfurter Allegemeine Zeitung 26, 93

frequency of contacts, accession 136

'functional interest representation' 197

funding: accession countries 136-8; activities of regions in Brussels 150-67

future research 166, 173, 188, 209

Germany: alignments and arguments 19-38; business interest associations 114, 117-22; conflict perception and venue choice 43-62; corporatist system 177 ; density of interests 205 ; diversity 171-89; information strategies 66-83; selective exit 93-8

governance, accession countries 136-8

Great Britain 171-89

Greece 157-66

Greens 72

Gross Domestic Product (GDP) 25, 204-8

group types 36

Hafner-Fink, Mitja 19-38

Hanegraaff, Marcel 171-89

Heckman procedure/model 116-17

Hirschmann response 87-102, 103n1

Horizon 2020166

horizontal venue shifts 47,60

ideological positions: activities of regions in Brussels 159; alignments 8-9, 21-3, 35,37 ; information strategies $66-83$

influence 109, 153, 158

information brokers 113

information exchange 113

information flow $88,92-8$ 
information strategies: conclusion 81-2; data and research design 73-5; discussion 79-81; overview $12,66-8$; partisan contacts 75-9; political logic, MP's information demands 68-73; routine exchanges 97; scarcity 69-71, 79

institutions, regions activities in Brussels 154-6

Interarena project 178

intercoder-reliability test $178-9$

INTEREURO project 11, 26, 31, 92, 195, 200-1

intermediary activities of regions in Brussels 150-67

International Labour Organization 131

inverse density 205

Italy 205

joint domestic mobilisation 38

Kohler-Koch, Beate 108-24

Kotzian, Peter 108-24

Krippendorff's alpha 31

Kruskall-Wallis test 76

Latvia 205

left-leaning political parties: alignment 20, 22,35 ; information strategies 66-83

legitimacy 112-13, 166, 196, 209

Le Monde 26, 93

liaison activities 153, 158, 161-3

like-mindedness: information strategies $66-83$; seeking out $20,34,37-8$

Lisbon Treaty 153

Lithuania 204

lobbying: business interest associations 111-12, 116-17; conflict perception and venue choice 44, 45-50, 59, 61; European Parliament 194-210; as exchange relation 110; large firms, policy-making 44; multilevel 116-17; selective exit 88 , $91,103 n 8$

logistic regressions see exact logistic regressions

loyalty 90

Luxembourg 157-66

Macedonia 129-46

Malta 157-66, 204

Marshall, David 43-62

MAXQDA 31

media: information strategies 69 ; selective exit $88,96,102$ membership: accession countries 139-40; accession process 135-6; EU-level associations 139-40; future membership 128; involvement 183-5; outsourcing activities 173, 177; selective exit 89-90, 94-5, 100

members of Parliament (MPs) 67-8

Montenegro 129-46

multiplicity, information strategies 82

multivariate analysis 117-22

multivariate regression models 56-7

national contexts 36

national interest organisations $1-5$

national investor compensation $38 \mathrm{n} 5$

(neo)corporatism: access frequency 114; conflict perception and venue choice 44

the Netherlands: alignments and

arguments 19-38; corporatist system

177 ; density of interests $204-5$; diversity

171-89; selective exit 93-8

networking, activities of regions in Brussels $150-67$

'new member state' dummy variable 166 n6

Nice Treaty 153

non-governmental organizations

(NGOs): accession process 139, 141;

Europeanisation 130-2; information

strategies 75-7; pre-existence 135

non-parametric difference of means test 76

Novak, Meta 19-38

obligations, reallocating 24

'obmann' 73

observer status 135-6

OECKL Deutschland 178

Olsonian logic, collective action 26

operationalisation: accession countries

134-5; business interest associations

114-16

ordered logit models 159, 163

ordinal probit model 117

ordinary least squares (OLS) regression models $83 n 5,181-2$

'overlap issues' 46

Parlgov database $74,83 \mathrm{n} 2$

parliamentarians 66-83

parsimonious rational choice: business

interest associations $110-14$

participation patterns $4,33-4,38$

partisan contacts 75-9

partisanship 154-6 
Pearson's $r 32$

performance failures 102; see also selective exit

persuasion 70,72

pluralism and pluralist systems: accession, post-communist democracies 131; conflict perception and venue choice 44 , 48-50, 59-60

Poland: access 122; accession 132; business interest associations 114, 117-22; density of interests 205; regions activities in Brussels 163

Policy Agendas project 25

policy contexts 36-7

policy-making process $150-67$

political logic 68-73

Portugal 204

position and position papers:

alignment 8-9, 21-3, 25, 30, 37;

information strategies 73 ; selective exit 91, 92-8

post-communist democracies 128-9, $131-4$

'preference-centeredness' 81

pressure, exertion of 91

professional associations 136-7, 139

proposals, new $v s$. recast 8

public goods $89,91,94$

pull/push factors 50

Pyttersen Almanak 178, 189n2

Quittkat, Christine 108-24

rank-ordering 154, 157-8, 165

Rasch, Daniel 1-15, 19-38

Rasmussen, Anne 194-210

redistributive welfare state agenda 72

regions activities in Brussels: age and experience 161-5; conclusion 165-6; data 157-60; institutions 154-6; overview 13-14, 150-1; partisanship 154-6; resources, office-level 154-6; types of activities 151-4

regression analysis 142

relationship, measurement of quality $52-3$

relative conflict 59

representation: business interest associations 121-2, 123; conflict perception and venue choice $48,53-4$, 59; cultural capital and density of interests 197

representational capacity $173,176-7$, $179,183-5$ resources: access 123-4; cultural capital and density of interests 209; full-time staff 158-9; office-level 154-6; selective exit 90

right-leaning political parties 66-83

rights, reallocating $24,31-2,35-6$

RILE index 32

Rozbicka, Patrycja 1-15, 19-38

screening, information strategies 80 sectoral associations 113-14, 121-2 selective exit: 'Brexit' 61; conclusion 102-3; data and research design 92-8; exact logistic regressions $98-101$; information flow 92-8; in the interest group system $88-92$; overview 9 , 12-13, 87-8; position 92-8; see also exit

self-government/self-rule 159, 163, $166,166 \mathrm{n} 5$

self-selection bias 115

Serbia 129-46

size: as benchmarks 195; measurements 61n3; regression coefficient comparison 77

Slovakia 205

Slovenia: access 122; activities of regions in Brussels 157-66; alignments and arguments 19-38; density of interests 204; selective exit 93-8

Social Democrats (SPD) 76

Spearman's rho correlation $82 \mathrm{n} 1$

staff: activities of regions in Brussels 158-9, 163; contact frequencies 142; information strategies 69, 81

Standard \& Poor's Capital IQ database 51

status quo supporters 34

subscription fees 89

subsectoral associations 113-14, 117

subsidy perspective 70

Sweden: alignments and arguments 19-38; as corporatist system 48 ; selective exit 93-8

Tatham, Michaël 150-67

'territorial interest representation' 197

think tanks: accession process 135,139 , 141, 145-6; activities of regions in Brussels 152; diversity 176; EU policy process 8; lobbying 195

top-down strategies 9, 11, 177

trade-offs: accession process 137 ; information strategies 82 
trade unions 135; see also unions

'transmission belt' function 173, 176, 179,188

Transparency Register 200, 210n8

tripartite social dialogue 131

umbrella organizations 139

unions: accession process 137;

information strategies 75-7; pre-

existence 135

United Kingdom (UK): alignments and arguments 19-38; business interest associations 114, 117-22; conflict perception 43-62; pluralist system 48, 177; selective exit 93-8

United States, pluralist system $48-9$ variables: accession countries 135-6; selective exit 95-6

venues: actors index value 30 ; alignments and arguments 20-5; conflict perception and venue choice 44-50, 60

vertical venue shifts 47,60

voice, selective exit $87-103$

voluntary associations $199-200$

voting behavior 81

watchdog activities 132

Wonka, Arndt 66-83

working-level $v s$. decision-making level 111

World Bank 131

Yugoslavia 134 